\title{
Off-Gas Characteristics of Defense Waste Vitrification Using Liquid-Fed Joule- Heated Ceramic Melters
}
R. W. Goles
G. J. Sevigny

September 1983

$$
\text { 6. 4 : }
$$

Prepared for the US. Department of Energy under Contract DE-AC06-76RLO 1830

Pacific Northwest Laboratory Operated for the U.S. Department of Energy by Battelle Memorial Institute

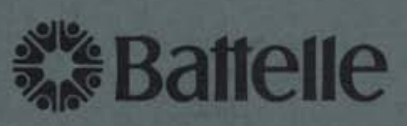




\section{DISCLAIMER}

This report was prepared $a s$ an account of work sponsored by an agency of the United States Government. Neither the United States Government nor any agency thereof, nor any of their employees, makes any warranty, express or implied, or assumes any legal liability or responsibility for the accuracy, completeness, or usefulness of any information, apparatus, product, or process disclosed, or represents that its use would not infringe privately owned rights. Reference herein to any specific commercial product, process, or service by trade name, trademark, manufacturer, or otherwise, does not necessarily constitute or imply its endorsement, recommendation, or favoring by the United States Government or any agency thereof. The views and opinions of authors expressed herein do not necessarilystate or reflect those of the United States Government or any agency thereof.

\section{PACIFIC NORTHWEST LABORATORY operated by BATTELLE forthe UNITED STATES DEPARTMENT G ENERGY under Contract DE-AC06-76RLO 1830}

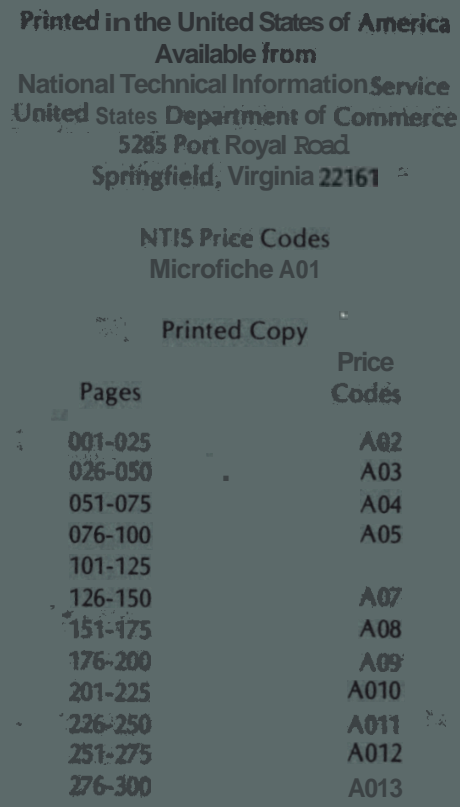


OFF-GAS CHARACTERISTICS OF DEFENSE WASTE VITRIFICATION USING LIQUID-FED JOULE-HEATED CERAMIC MELTERS

R. W. Goles

G. J. Sevigny

September 1983

Prepared for the U.S. Department of Energy under Contract DE-AC06-76RLO 1830

Pacific Northwest Laboratory

Richland, Washington 99352 



\section{SUMMARY}

Off-gas and effluent characterization studies have been established as part of a PNL Liquid-Fed Ceramic Melter development program supporting the Savannah River Laboratory Defense Waste Processing Facility (SRL-DWPF). The objectives of these studies were to characterize the gaseous and airborne emission properties of liquid-fed joule-heated melters as a function of melter operational parameters and feed composition.

All areas of off-gas interest and concern including effluent characterization, emission control, flow rate behavior and corrosion effects have been studied using alkaline and formic-acid based feed compositions. In addition, the behavioral patterns of gaseous emissions, the characteristics of meltergenerated aerosols and the nature and magnitude of melter effluent losses have been established under a variety of feeding conditions with and without the use of auxiliary plenum heaters.

The results of these studies have shown that particulate emissions are responsible for most radiologically important melter effluent losses. Meltergenerated gases have been found to be potentially flammable as well as corrosive. Hydrogen and carbon monoxide present the greatest flammability hazard of the combustibles produced. Melter emissions of acidic volatile compounds of sulfur and the halogens have been responsible for extensive corrosion observed in melter plenums and in associated off-gas lines and processing equipment. The use of auxiliary plenum heating has had little effect upon melter off-gas characteristics other than reducing the concentrations of combustibles. 



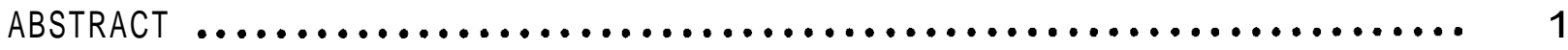

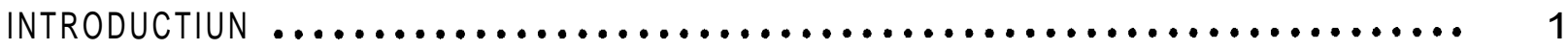

LIQUID-FED MELTER PROCESSING SYSTEM $\ldots \ldots \ldots \ldots \ldots \ldots \ldots \ldots \ldots \ldots \ldots \ldots . \ldots \ldots$

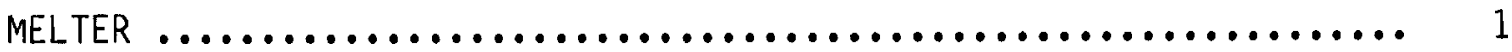

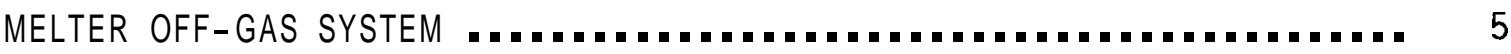

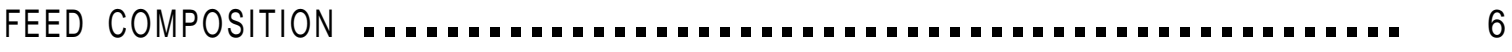

EFFLUENT CHARACTERIZATION ...................................... 8

OFF-GAS SAMPLING NETWORK .............................. 8

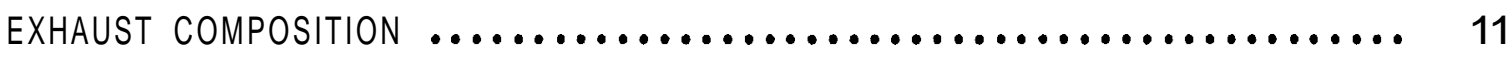

NATURE OF MELTER FEEd COMPONENT LOSSES $\ldots \ldots \ldots \ldots \ldots \ldots \ldots \ldots \ldots \ldots . . . . .20$

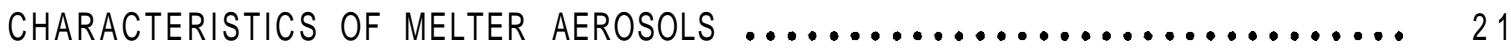

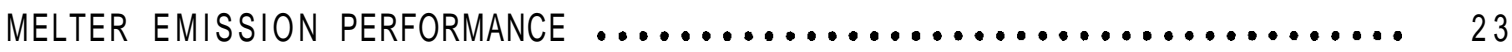

MELTEK IDLING TEST $\ldots \ldots \ldots \ldots \ldots \ldots \ldots \ldots \ldots \ldots \ldots \ldots \ldots \ldots \ldots \ldots \ldots, 28$

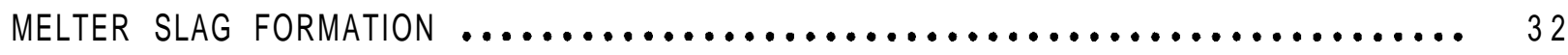

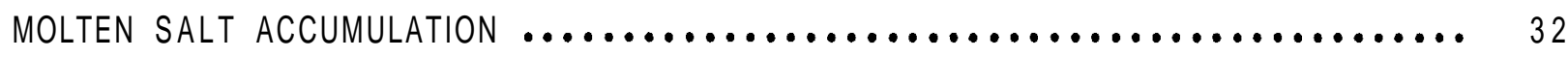

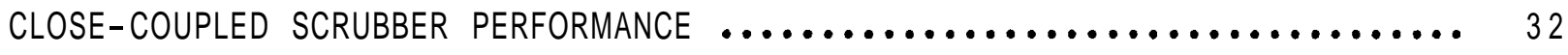

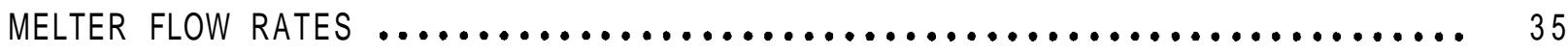

CORROSION

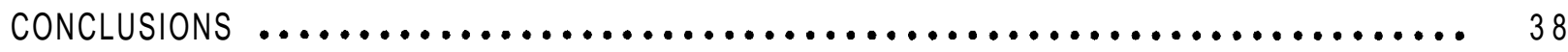

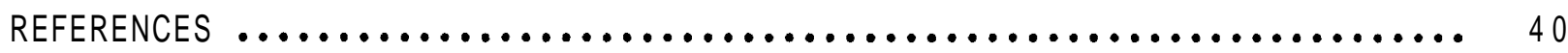

APPENDIX - OFF-GAS DATA COMPILATION FOR LIQUID FEEDING

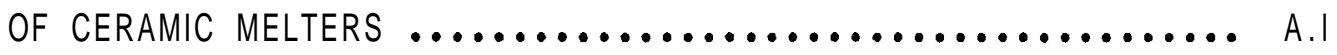

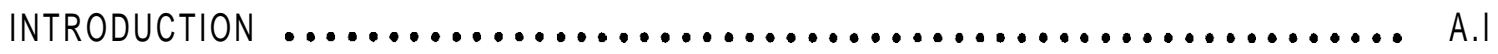

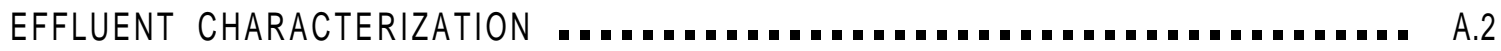

LFCM-2 - SEPTEMBeR $1980 \ldots \ldots \ldots \ldots \ldots \ldots \ldots \ldots \ldots \ldots \ldots \ldots \ldots$ A.2 
LFCM-3 - NOVEMBER $1980 \ldots \ldots \ldots \ldots \ldots \ldots$

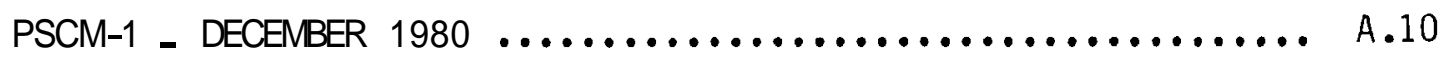

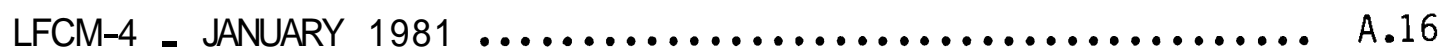

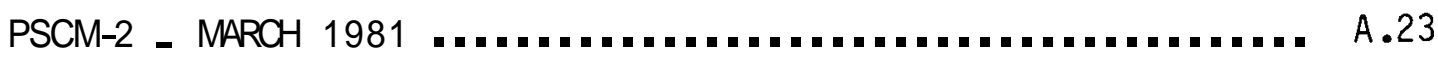

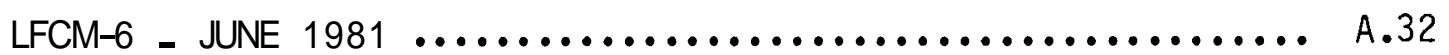

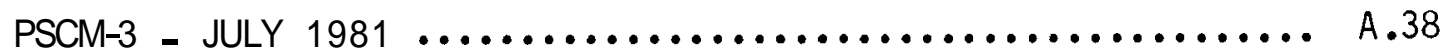

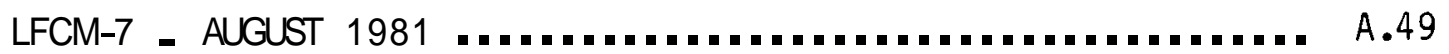

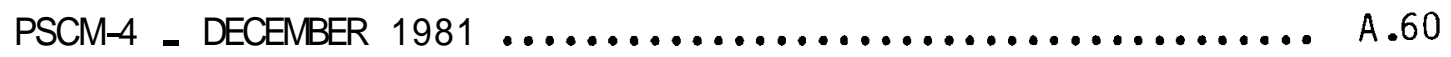

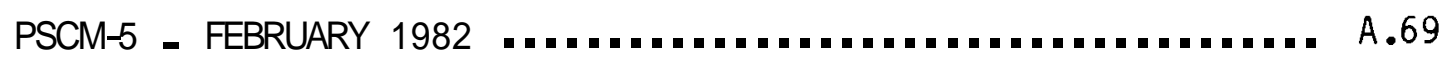

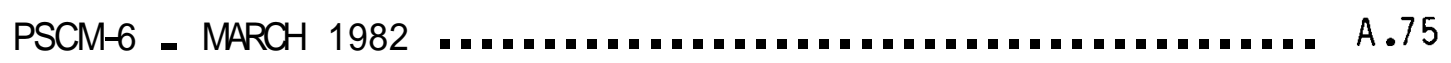

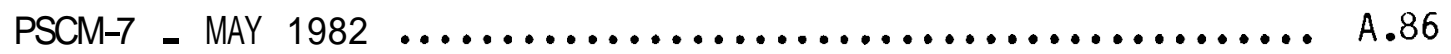

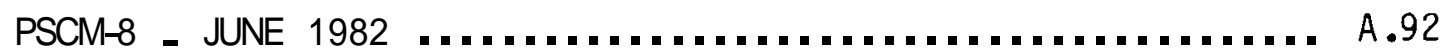

OFF-GAS ROW RATES $\ldots \ldots \ldots \ldots \ldots \ldots$

LFCM-4 - JANUARY $1981 \ldots \ldots \ldots \ldots \ldots \ldots \ldots \ldots \ldots \ldots \ldots \ldots \ldots \ldots \ldots$

LFCM-6 - JUNE $1981 \ldots \ldots \ldots \ldots \ldots \ldots \ldots \ldots \ldots \ldots \ldots \ldots \ldots \ldots \ldots \ldots \ldots \ldots \ldots$. . . . . . . . . . . .

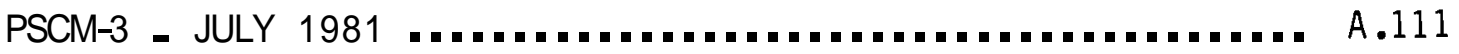

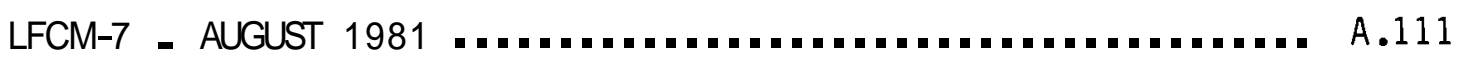

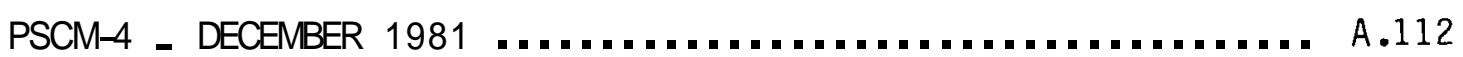

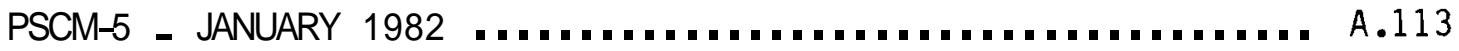

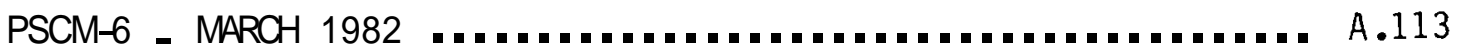

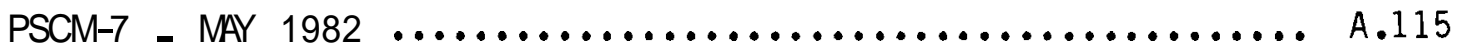

PSCM-8 - JUNE 1982 ............................. A.116

MELTER IDLING TESTS $\ldots \ldots \ldots \ldots \ldots \ldots \ldots \ldots \ldots \ldots \ldots \ldots \ldots \ldots \ldots \ldots \ldots \ldots \ldots$

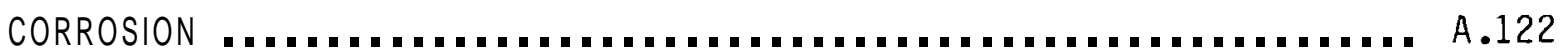

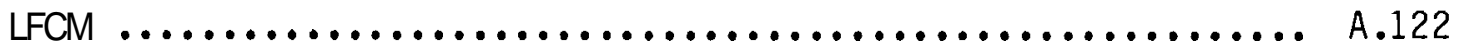

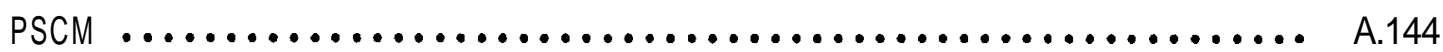




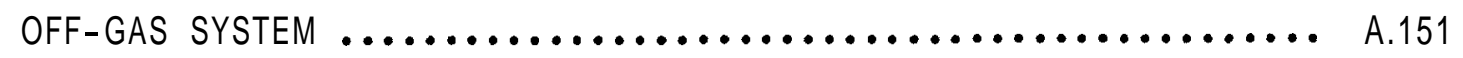

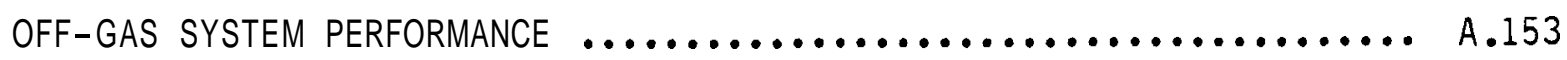

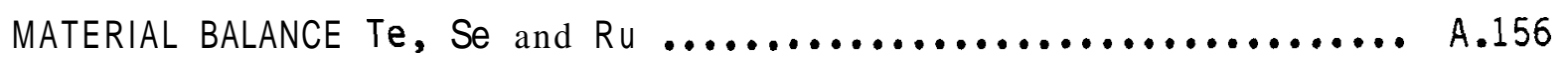




\section{FIGURES}

1 Liquid-Fed, Joule-Heated Ceramic Melter System ............... 4

2 Melter Off-Gas Sampling Network $\ldots \ldots \ldots \ldots \ldots \ldots \ldots \ldots \ldots \ldots \ldots \ldots \ldots \ldots$

3 Composition of Combustion Boosted Melter Exhaust .............. 11

4 Melter Exhaust Gas Composition of a 100-h Boosted. 20-h

Unboosted Test ........................................ 12

5 Compositional Behavior of Noncondensible Melter Exhaust Gases Accompanying a Flow Surge ............................... 14

6 Melter Off-Gas Compositional Behavior Associated with Feed Termination ......................................... 15

7 Melter $\mathrm{SO}_{2}$ Emission Characteristics Accompanying a 240-h Test $\ldots . . .17$

8 Melter Idling Emission Rates of Semivolatile Elements ............ 28

9 Typical Off-Gas Flow Rate Behavioral Patterns Associated with Liquid-Fed Melters ................................. 34

\section{APPENDIX}

A.I Off-Gas Treatment System ............................ A4

A.2 LFCM-2 Off-Gas Line Schematic .......................... A.5

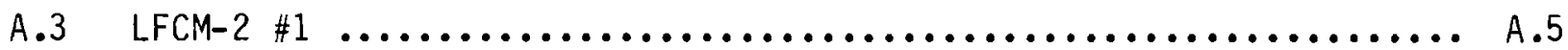

A.4 LFCM-2 \#2 $\ldots \ldots \ldots \ldots \ldots \ldots \ldots \ldots \ldots \ldots \ldots \ldots \ldots \ldots \ldots \ldots \ldots \ldots \ldots \ldots \ldots \ldots \ldots$

A.5 LFCM -2 \#3 $\ldots \ldots \ldots \ldots \ldots \ldots \ldots \ldots \ldots \ldots \ldots \ldots \ldots \ldots \ldots \ldots \ldots \ldots \ldots \ldots \ldots \ldots$

A6 LFCM-2 Mass-Size Particle Distribution ................... A.9

A7 PSCM-1 Off-Gas-Line Schematic $\ldots \ldots \ldots \ldots \ldots \ldots \ldots \ldots \ldots \ldots \ldots \ldots \ldots \ldots$

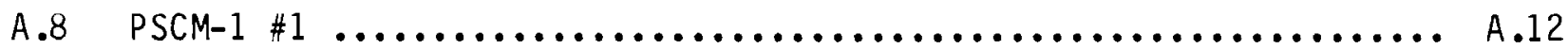

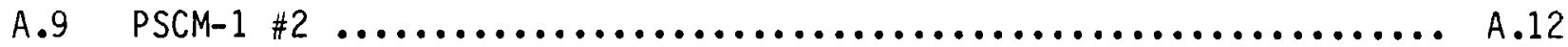

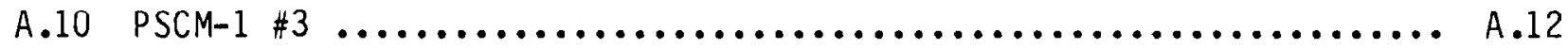

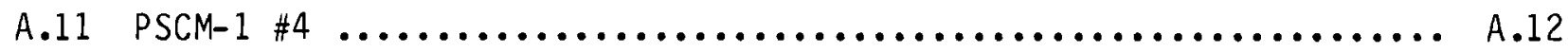

A.12 PSCM-1 $\# 5 \quad \ldots \ldots \ldots \ldots \ldots \ldots \ldots \ldots \ldots \ldots \ldots \ldots \ldots \ldots \ldots \ldots \ldots \ldots \ldots \ldots \ldots \ldots \ldots$ 


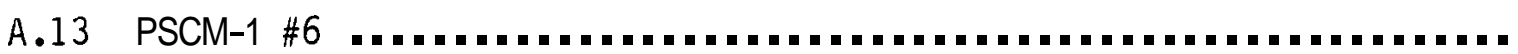

A.14 PSCM-1 \#8

A.15 PSCM-1 \#9

A.16 PSCM-1 \#10

A.14

A.17 PSCM-1 \#11

A.14

A.18 PSCM-1 \#12

A. 14

A.19 PSCM-1 \#13 A.14

A.20 PSCM-1 \#14

A. 15

A.21 PSCM-1 \#15

A.15

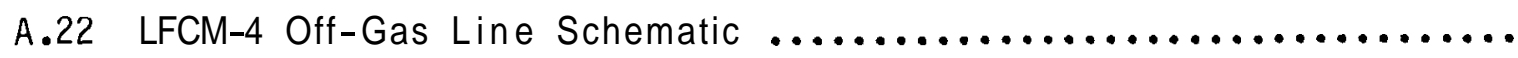
A. 18

A.23 LFCM-4 \#4 A.18

A.24 LFCM-4 \#3 A.18

A.25 LFCM-4 \#2 A.19

A.26 LFCM-4 \#1 A.19

A.27 LFCM-4 \#0 A.19

A.28 PSCM-2 Off-Gas Line Schematic .......................... A. 25

A.29 PSCM-2 \#1 A.26

A.30 PSCM-2 \#2 A.26

A.31 PSCM-2 \#3 A. 26

A.32 PSCM-2 \#4 A.26

A.33 PSCM- $2 \# 5$ A. 27

A.34 PSCM-2 \#6 A. 27

A.35 PSCM-2 \#7 A.27

A.36 PSCM-2 \#8 A. 27

A.37 PSCM- $2 \# 9$ A.28

A.38 PSCM-2 \#10 A. 28 


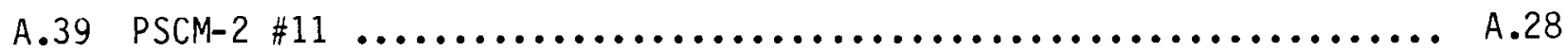

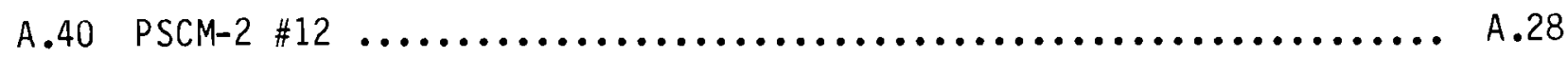

А.41 PSCM-2 \#13 $\ldots \ldots \ldots \ldots \ldots \ldots \ldots \ldots \ldots \ldots \ldots \ldots \ldots \ldots \ldots \ldots \ldots \ldots \ldots \ldots$ A.29

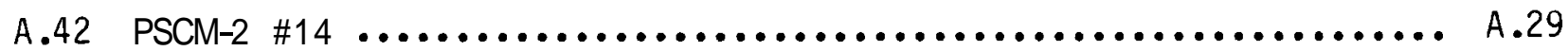

A.43 PSCM-2 Plenum Off-Gas Composition ........................ A.33

A.44 LFCM-6 Off-Gas Line Configuration ......................... A.34

A.45 LFCM-6 Melter Lid ........................................ A.35

A.46 LFCM-6 \#4 ............................................ A.35

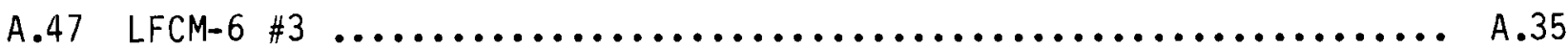

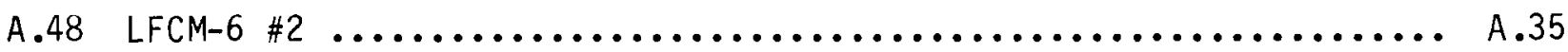

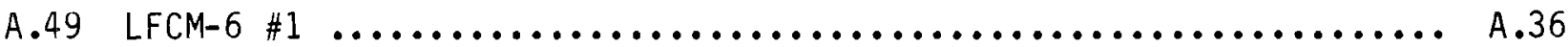

A.50 LFCM-6 \#0 ................................................. A.36

A.51 PSCM-3 Off-Gas-Line Configuration .......................... A.42

A.52 PSCM-3 \#1............................................... A.43

A.53 PSCM-3 \#2 ............................................ A.43

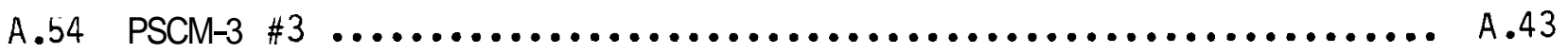

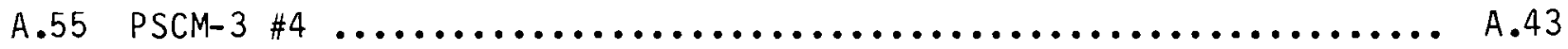

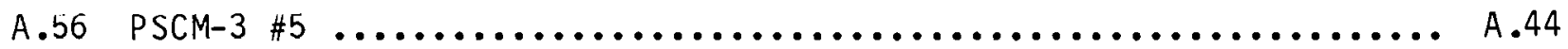

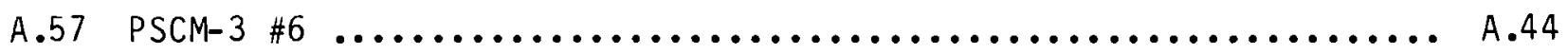

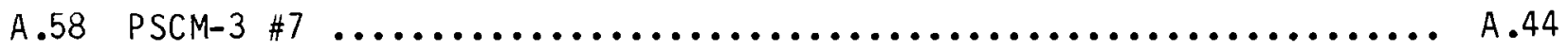

A.59 PSCM $-3 \# 8 \quad \ldots \ldots \ldots \ldots \ldots \ldots \ldots \ldots \ldots \ldots \ldots \ldots \ldots \ldots \ldots \ldots \ldots \ldots \ldots . \ldots . \ldots \ldots$

A.60 PSCM $-3 \# 9$.......................................... A.45

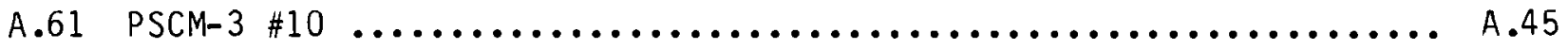

A.62 PSCM-3 \#11 .............................................. A.45

A.63 PSCM-3 Noncondensible Off-Gas Composition ..................... A.50

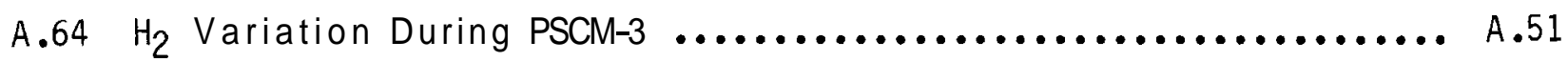


A.65 LFCM-7 Noncondensible Off-Gas Composition $\ldots . \ldots \ldots \ldots \ldots \ldots \ldots \ldots$............

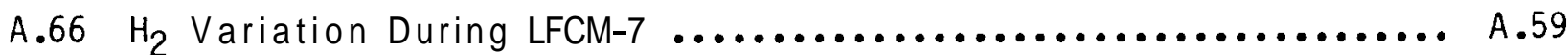

A.67 PSCM Off-Gas-Line Confiyuration ........................... A.61

A.68 PSCM-4 Off-Gas-Line Horizontal Section ....................... A.62

A.69 PSCM-4 Off-Gas-Line Horizontal Section ...................... A.62

A.70 PSCM-4 Off-Gas-Line Vertical Section ....................... A.62

A.71 PSCM-4 Off-Gas Composition ................................ A.67

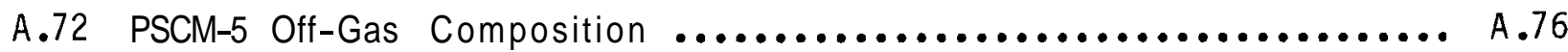

A.73 PSCM-5 Of f-Gas Composition .............................. A.77

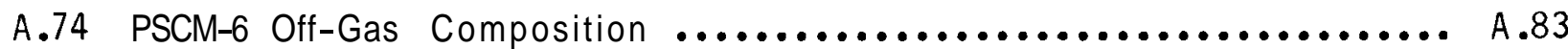

A.75 Melter Off-Gas Compositional Behavior Associated with Feed Termination ............................................... A.85

A.76 PSCM-7 Off-Gas Composition .................................. A.94

A.77 Material Buildup in Melter Plenum Exhaust Port - Axial Hose was Where Spray Nozzle was Located .............................. A.96

A.78 Horizontal Off-Gas Line .................................... A.96

A.79 SEM Photographs of Particulate Samples Taken Downstream of the Close-Coupled Scrubber ..................................... A.102

A.80 X-Ray Fluorescence Spectra of Individual Particles Called Out

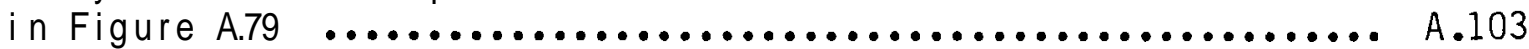

A.81 PSCM-8 Off-Gas Composition ............................... A.105

A.82 Compositional Behavior of Noncondensible Melter Exhaust Gases

Accompanying a Flow Surge .................................. A.106

A.83 Melter $\mathrm{SO}_{2}$ Emission Characteristics Accompanying a -240 -h Test

A.84 LFCM-4 Off-Gas Flow Rate Behavior ............................. A.109

A.85 PSCM-5 Off-Gas Flow Characteristics ........................... A.114

A.86 Qualitative Index of Off-Gas Flow Rate Instabilities ............ A.117

A.87 Melter Idling Emission Rates of Semivolatile Elements ........... A.120 
A.88 Underside of LFCM Lid North

A.89 SEM Photograph of $\mathrm{Ni}-\mathrm{Cr}$ Base Coat Under $100 \mathrm{X}$

Maynification - Control

A.90 SEM Photograph of $\mathrm{Ni}-\mathrm{Cr}$ Base Coat Showing Very Little Corrosion Under 100X Magnification

A.91 SEM Photograph of $\mathrm{Ni}-\mathrm{Cr}-6 \%$ Base Coat with a $\mathrm{Cr}_{2} \mathrm{O}_{3}$ Secondary Coat Under 100X Magnification - Control

A.92 SEM Photograph of $\mathrm{Ni}-\mathrm{Cr}-6 \%$ Base Coat with a $\mathrm{Cr}_{2} \mathrm{O}_{3}$ Secondary Coat and Some Cracking Under 100X Magnification

A.93 SEM Photograph of Zro-Coated Sample with a $\mathrm{Ni-Cr}$ Base Coat Under 100X Maynification - Control

A.94 SEM Photograph of ZrO-Coated Sample with a Ni-Cr Base Coat Under $100 \mathrm{x}$ Magnification...

A.95 Inconel-625 Unexposed Sample Under 10X, 100X and 250X

SEM Magnification .................................... A.134

A.96 Inconel-625 Sample Under 10X, 100X and 250X SEM Magnification .... A.135

A.97 Inconel-625 Sample Under 10X, 100X and 250X SEM Magnification .... A.136

A.98 Hastelloy Sample X Under 10X, 100X and 250X SEM Magnification .... A.137

A.99 Haynes 188 Sample \#1 Under 10X SEM Magnification ............... A.138

A.IOO Haynes 188 Sample \#I Under 100X and 250X SEM Magnification ....... A.139

A.I01 Haynes 188 Sample \#2 Under 10X, I00X and 25UX SEM

Magnification ................................... A.140

A.102 Haynes 25 Sample Under 10X, 100X and 250X SEM Magnification ...... A.141

A.103 Inconel-690 Sample Under 10X, 100X and 250X SEM Magnification .... A.142

A.104 PSCM Plenum Heater Thimbles .............................. A.145

A.105 Inconel-600 Thimble 8X SEM Cross Section with 50X and

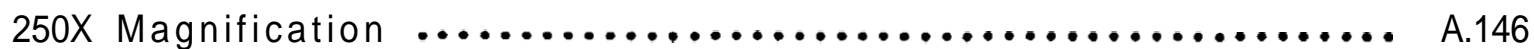

A.106 Inconel-600 Thimble Cross Sections of Regions B and C Under 50X and 250X Magnifications 
A.108 Inconel-601 Cross Section Under 100X and 250X SEM

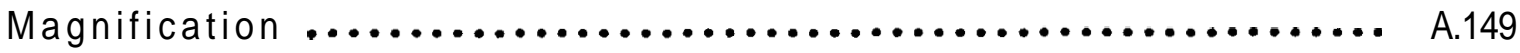

A.109 Inconel-690 Thimble Cross Section Under 8.3X, 100X and 250X

SEM Magnification ..................................... A.150

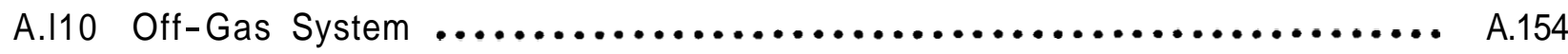

A.Ill Material Buildup in Melter Plenum Exhaust Port ................. A.155

A.112 PSCM-8 Melter Floor Survey $\ldots \ldots \ldots \ldots \ldots \ldots \ldots \ldots \ldots \ldots \ldots \ldots \ldots \ldots$ A.157

\section{TABLES}

1 Operational Parameters for Liquid-Fed Melter Tests .................

2 Simulated Waste Slurry and Glass Compositions .................. 5

3 Concentration of Trace Additives in Melter Feed ................. 6

4 Melter Noncondensible Off-Gas Composition ..................... 10

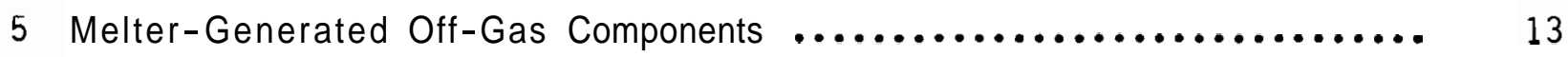

6 PSCM-6 Particulate and Total Feed Component DFs ................. 18

7 Size Distribution of Melter Aerosols ............................ 19

8 Elemental Distribution Across the Cyclonic Sampling System ........ 20

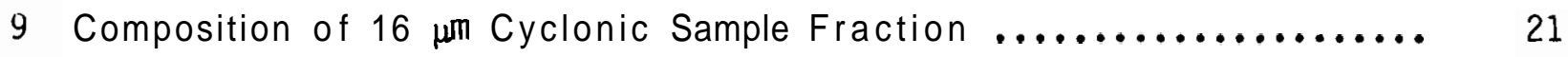

10 Submicron Particulate Composition ........................... 22

11 Melter Effluent Emission Characteristics ...................... 23

12 Steady-State Aerosol Emission Characteristics ................... 24

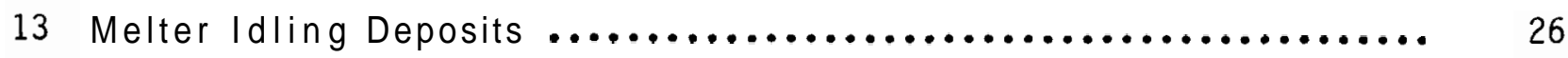

14 Relative Melter Production and Loss Rates of Sulfur .............. 30

15 Close-Coupled Scrubber Particulate DFs ......................... 32

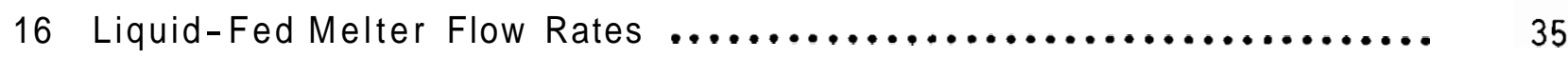

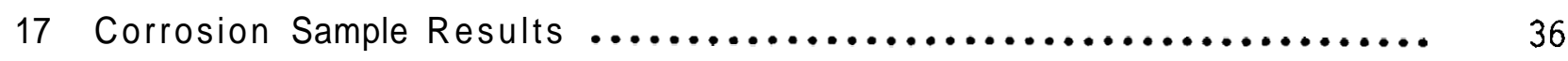




\section{APPENDIX}

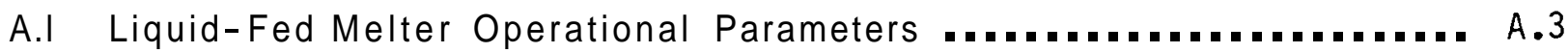

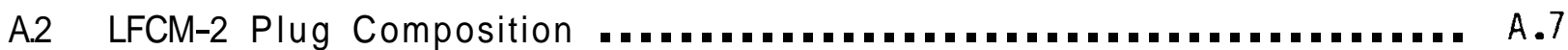

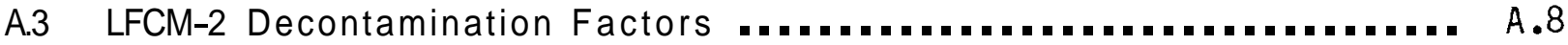

A.4 LFCM-3 Decontamination Factors ......................... A.10

A.5 PSCM-1 Process Line Deposits ............................ A.16

A.6 PSCM-1 Decontamination Factors ......................... A.17

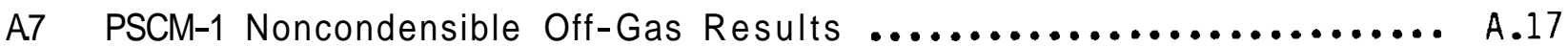

A.8 LFCM-4 Pipe Deposition Composition ......................... A.20

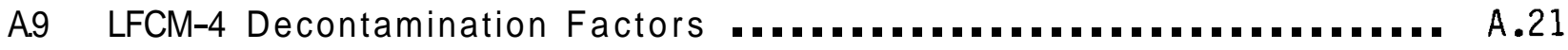

A.10 LFCM-4 Particulate Data ............................. A.22

A.11 LFCM-4 Noncondensible Off-Gas Composition .................. A.23

A.12 LFCM-4 Idling Emissions ............................... A.24

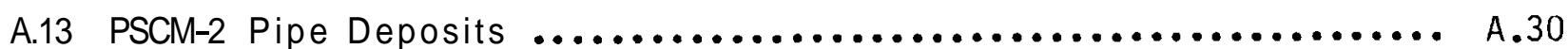

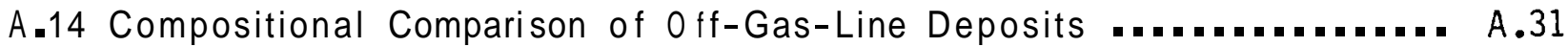

A.15 PSCM-2 Decontamination Factors $\ldots \ldots \ldots \ldots \ldots \ldots \ldots \ldots \ldots \ldots \ldots \ldots \ldots \ldots$ A. $\ldots \ldots$

A.16 LFCM-6 Off-Gas-Line Deposits ........................... A.37

A.17 Melter Pipe Deposition Composition ......................... A.38

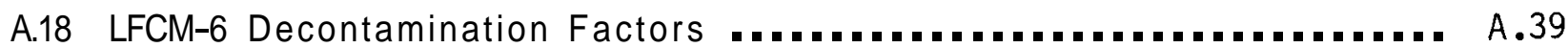

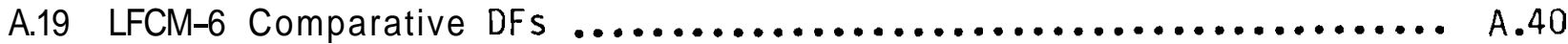

A.20 LFCM-6 Noncondensible Off-Gas Composition .................. A.41

A.21 PSCM-3 Pipe Deposition Composition ....................... A.46

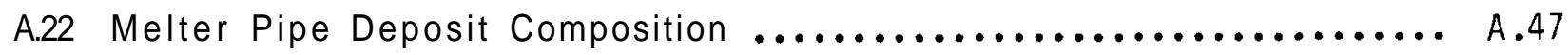

A.23 PSCM-3 Feed Component DFs ........................... A.48

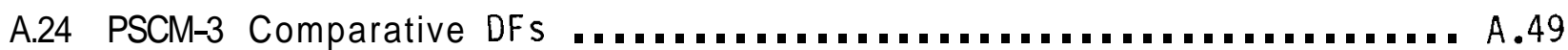

A.25 PSCM-3 Off-Gas Composition ............................ A.51 
A.26 Differential Particulate Data ................................... A.52

A.27 Elemental Distribution Across Cyclonic Sampling System ............ A.53

A.28 HEPA Filtration Data ........................................ A.54

A.29 Particulate Data from Off-Gas Sampling Train .................... A.55

A.30 Particulate and Total Feed Component DFs ......................... A.55

A.31 LFCM-7 Comparative DFs ..................................... A.56

A.32 Gross DF Values ......................................... A.57

A.33 LFCM-7 Off-Gas Composition ................................... A.59

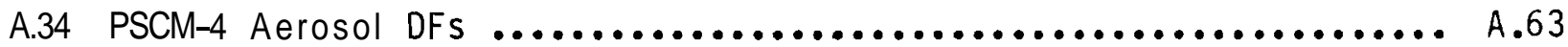

A.35 Particulate and Total Elemental Melter DFs ..................... A.63

A.36 PSCM-4 Comparative DFs $\ldots \ldots \ldots \ldots \ldots \ldots \ldots \ldots \ldots \ldots \ldots \ldots \ldots \ldots \ldots$ A.64

A.37 PSCM-4 Gross Aerosol DFs $\ldots \ldots \ldots \ldots \ldots \ldots \ldots \ldots \ldots \ldots \ldots \ldots \ldots \ldots \ldots$ A.65

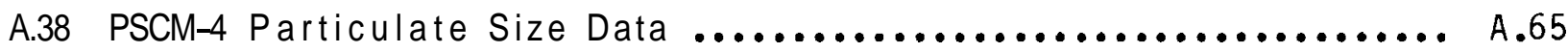

A.39 PSCM-4 Submicron Particulate Composition ...................... A.66

A.4.0 PSCM-4 Noncondensible Off-Gas Composition ..................... A.68

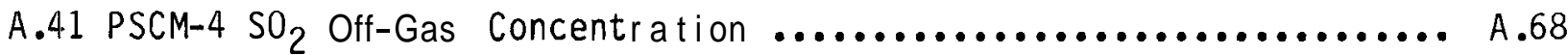

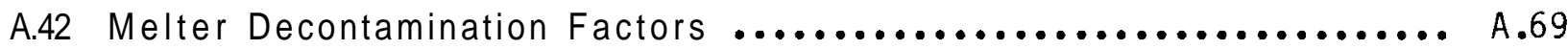

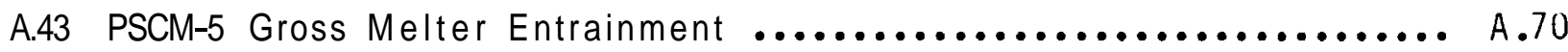

A.44 PSCM-5 Particulate and Total Feed Component DFs ................. A.71

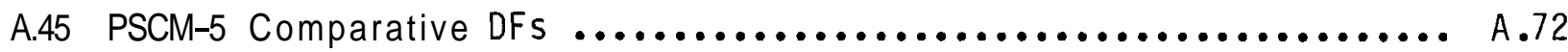

A.46 PSCM-5 Differential Particulate Data ......................... A.72

A.47 Elemental Distribution Across Cyclonic Aerosol Size Fractions ..... A.74

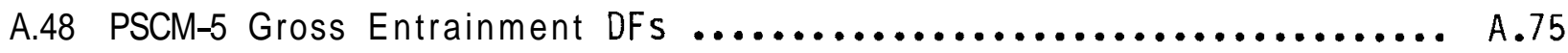

A.49 PSCM-5 Noncondensible Off-Gas Composition .................... A.78

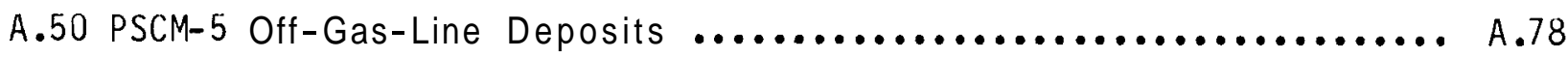

A.51 PSCM-6 Gross Melter Entrainment ............................... A.. A9 
A.52 PSCM-6 Particulate and Total Feed Component DFs ............... A.80

A.53 PSCM-6 Comparative DFs $\ldots \ldots \ldots \ldots \ldots \ldots \ldots \ldots \ldots \ldots \ldots \ldots \ldots \ldots \ldots \ldots \ldots \ldots \ldots$

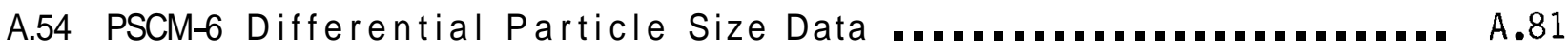

A.55 Feed Component Distribution Across Cyclonic Aerosol

Size Fractions ....................................... A.82

A.56 PSCM-6 Aerosol DFs ................................. A.83

A.57 PSCM-6 Off-Gas Composition .............................. A.84

A.58 Off-Gas-Line Deposits - PSCM-5 \& $-6 \ldots \ldots \ldots \ldots \ldots \ldots \ldots \ldots \ldots \ldots \ldots \ldots$

A.59 Gross Melter DF .................................... A.87

A.60 PSCM-7 Particulate and Total Feed Component DFs ............... A.88

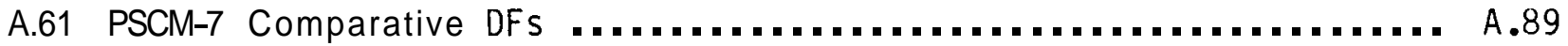

A.62 Cyclonic Melter Aerosol Size Analysis ........................ A.90

A.63 Elemental Distribution Across Cyclonic Size Fractions ............ A.91

A.64 PSCM-7 Close-Coupled Scrubber Particulate DFs ................ A.92

A.65 PSCM-7 Gross Aerosol DFs .............................. A.93

A.66 Melter Surface Samples After PSCM-7 ...................... A.95

A.67 Assumed Salt Compounds for PSCM-7, wt\% ..................... A.95

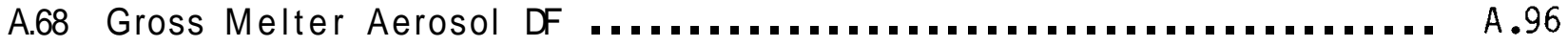

A.69 PSCM-8 Particulate and Total Melter Feed Component DFs .......... A.97

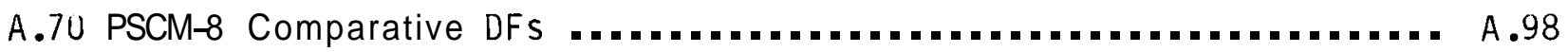

A.71 PSCM-8 Particulate Analysis of Melter Generated Aerosols ........ A.99

A.72 PSCM-8 Elemental Distribution Across Cyclonic Fractions ......... A.100

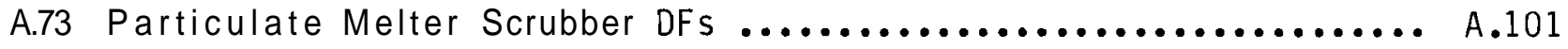

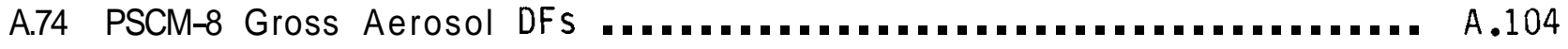

A.75 Flow Surging Characteristics During LFCM-4 .................. A.110

A.76 Frequency. Duration and Extent of LFCM-4 Surges ............... A.110 
A.77 LFCM-6 Surging Flow Rate Behavior ........................... A.111

A.78 PSCM-3 Flow Rate Behavior ................................. A.111

A.79 LFCM-7 Flow Rate Behavior ................................. A.112

A.80 Off-Gas Surging Behavior .................................. A.112

A.81 PSCM-5 Off-Gas Flow Rate Behavior ............................ A.113

A.82 PSCM-6 Off-Gas Flow Characteristics .......................... A.115

A.83 Noncondensible Gas Flow .................................... A.116

A.84 PSCM-8 Flow Data $\ldots \ldots \ldots \ldots \ldots \ldots \ldots \ldots \ldots \ldots \ldots \ldots \ldots \ldots \ldots \ldots \ldots \ldots$ A.118

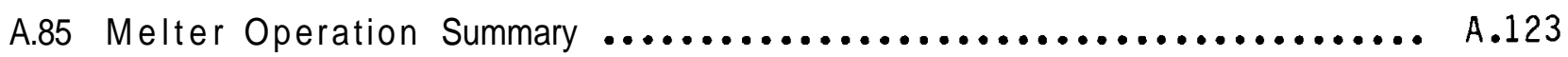

A.86 Composition of Material from Off-Gas Plug .................... A.124

A.87 Metallic Corrosion Sample Results .......................... A.126

A.88 Protective Coating Off-Gas Samples $\ldots \ldots \ldots \ldots \ldots \ldots \ldots \ldots \ldots \ldots \ldots \ldots$ A.127

A.89 Spray Powder Characteristics ............................. A.128

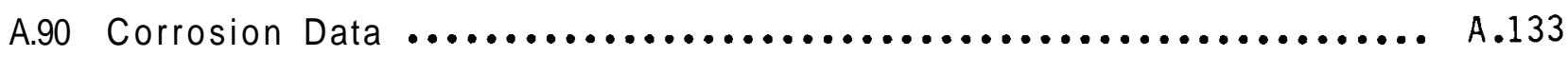

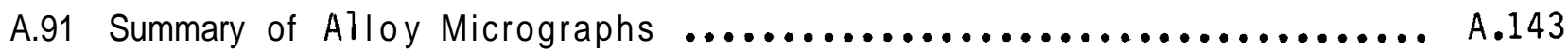

A.92 Plenum Thermowell Measurements ............................ A.151

A.93 Metal Found on Melter Floor .............................. A.158

A.94 Te, Se. and Ru Material Between PSCM-4 \& PSCM-8 ................ A.159 



\section{INTRODUCTION}

Liquid-fed, joule-heated ceramic melters are to form the basis of the planned Defense Waste Processing Facility (DWPF) to be constructed at the Savannah River Plant (SRP). The purpose of the DWPF is to isolate and immobilize defense-related nuclear waste in a borosilicate glass. Pacific Northwest Laboratory (PNL) is assisting the Savannah River Laboratory (SRL) in establishing the design criteria for the DWPF by transferring existing melter technoloyy and by providing all necessary liquid-fed ceramic melter research and development.

Off-gas characterization studies have been established as part of the SRLDWPF melter development proyram being conducted at PNL. The objective of these studies is to determine the off-gas properties of liquid-fed, joule-heated melters as a function of melter operational parameters and feed composition.

The scope of these studies covers all aspects of off-gas concern including: 1) effluent characterization, 2) emission abatement, 3) flow rate behavior, and 4) corrosion effects. This paper will discuss the results obtained from studies of each of these areas of interest after a brief description of the liquid-fed melter process.

\section{$\underline{\text { LIQUID-FED MELTER PROCESSING SYSTEM }}$}

The following is a brief description of the liquid-fed melter processing system which was developed at PNL in support of the SRP-DWPF. A much more detailed account of the liquid-fed melting process can be obtained from a report by Buelt and Chapman (1978).

\section{MELTER}

Several processes for solidifying and immobilizing high-level liquid waste (HLLW) in a stable borosilicate glass continues to be evaluated at PNL (Bonner 1979). The process being studied here utilizes a joule-heated ceramic-lined melter, which is directly fed a uniform slurry composed of glass formers and simulated liquid radioactive waste. Upon entry into the melter, the waste 
components of the slurry are oxidized and melted with the glass formers present in the feed to form a molten borosilicate glass.

The power required to maintain this continuous glass production process is supplied by resistive alternate current (ac) heating of the melter glass pool. In addition to the primary source of power, auxiliary radiant heaters located in the melter plenum above the glass melt surface have been employed to increase or "boost" feeding and glass production rates. Plasma and propane combustion torches have also been used to supply additional heating to the melter plenum. Figure 1 illustrates the liquid-fed melting process.

Two different joule-heated ceramic melters used in these developmental studies are referred to as the liquid-fed ceramic melter (LFCM), which has a melting surface area of $1.05 \mathrm{~m}^{2}$, and the pilot-scale ceramic melter (PSCM), which possesses a $0.73 \mathrm{~m}^{2}$ surface area. The maximum ylass production rates associated with these melters are $40 \mathrm{~kg} / \mathrm{h}-\mathrm{m}^{2}$ for unboosted operation, and 60 $\mathrm{kg} / \mathrm{h}-\mathrm{m}^{2}$ when auxiliary plenum heaters are employed. Table 1 summarizes all important operational parameters associated with tests of the LFCM and PSCM. These melter tests, which are arranged chronoloyically in Table 1, form the bases of the off-gas studies which are discussed below.

\section{MELTER OFF-GAS SYSTEM}

Both the PSCM and LFCM share a common 0.1-m (4-in.) stainless steel offgas system consisting of an ejector venturi scrubber, a downdraft condenser, a packed scrubbing tower, and a final absolute filter, physically arranged in the order listed. In addition to these common off-gas elements, both melters are equipped with a close-coupled HEPA filter receptacle and a total (condensible and noncondensible) off-gas flowmeter. Since the purpose of the DWPF off-gas support studies was to establish melter off-gas characteristics, the performance of the generic off-gas processing equipment present in the common melter off-gas system was of little programmatic interest and consequently will not be discussed here. However, the operating characteristics of a close-coupled scrubber, utilized during the last two pilot-scale melter tests, will be discussed since such a device will be required in support of full-scale production melters. 


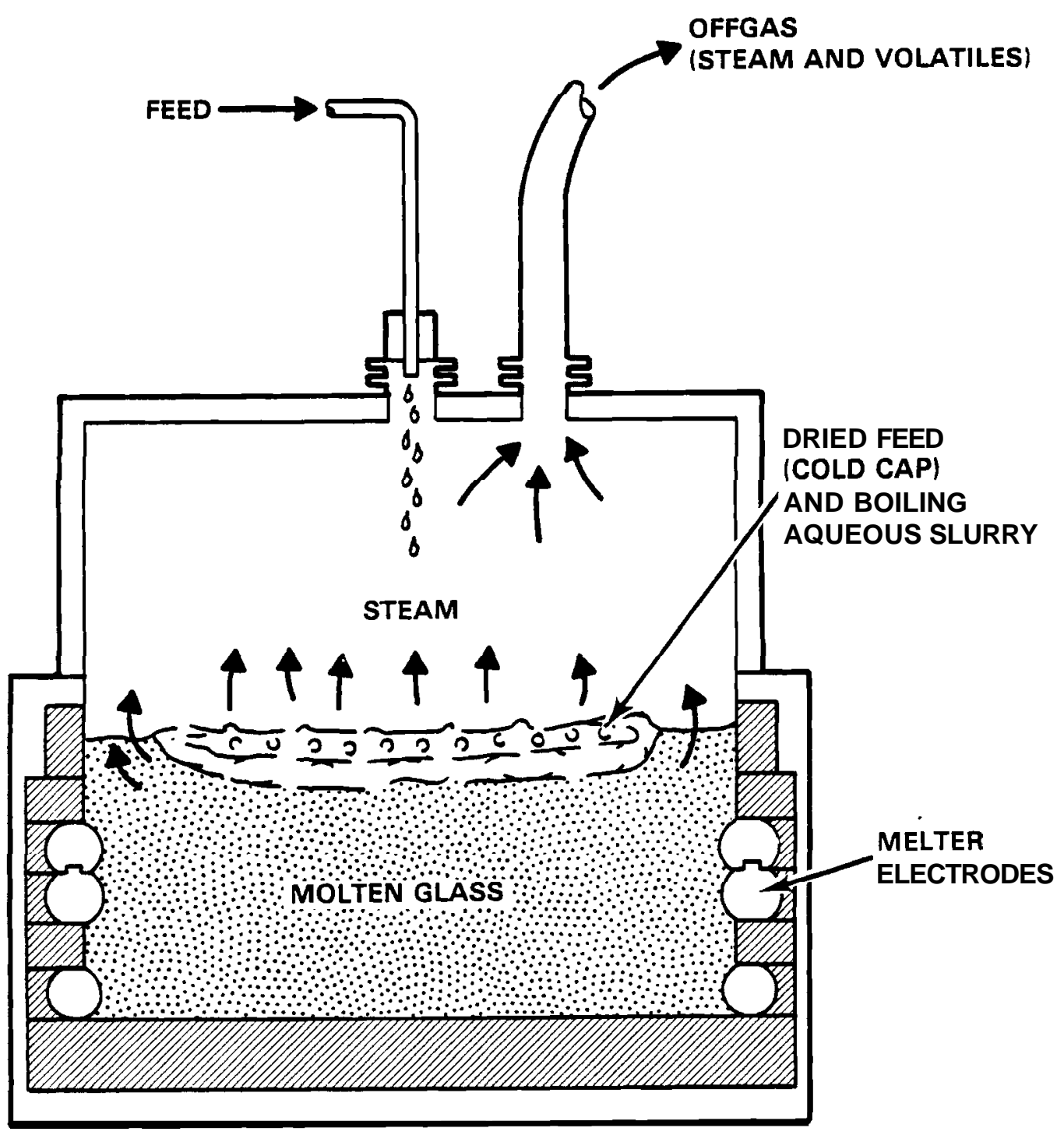

FIGURE 1. Liquid-Fed, Joule-Heated Ceramic Melter System

\section{FEED COMPOSITION}

The liquid slurry feed used in the SRL-DWPF melter development program was a uniform mixture of simulated defense waste sludge and glass formers (frit). The composition of this slurry as equivalent oxides is detailed in Table 2. The effective waste loading of the slurry is $29 \mathrm{wt} \%$ of the total oxides present in the feed. In addition to the major elements listed in Table 2, SRL simulated waste also contained stable elemental substitutes for all volatile and 
TABLE 1. Operational Parameters for Liquid-Fed Melter Tests

\begin{tabular}{|c|c|c|c|c|c|c|c|c|c|c|c|}
\hline Parameters & PSCM-I & $\underline{\text { LFCM-4 }}$ & PSOM-2 & LCM-6 & PSCM-3 & LFCM-7 & PSCM-4 & PSCM-5 & PSCM-6 & PSCM7 & PSCM-8 \\
\hline Feed type & Basic & Basic & Basic & Basic & Acidic & Acidic & Acidic & Acidic & Acidic & Acidic & Acidic \\
\hline $\begin{array}{l}\text { Feed rate, } \\
V_{h-m^{2}}\end{array}$ & 45 & 90 & 110 & 100 & 62 & 121 & 83 & 100 & 122 & 68 & 103 \\
\hline $\begin{array}{l}\text { Glass prod. } \\
\text { rate, } \\
\mathrm{kg} / \mathrm{h}-\mathrm{m}^{2}\end{array}$ & 22 & 41 & 50 & 45 & 28 & 57 & 39 & 50 & 60 & 43 & 49 \\
\hline $\begin{array}{l}\text { Plenum } \\
\text { temp., }{ }^{\circ} \mathrm{C}\end{array}$ & 400 & 600 & $400-800$ & 600 & 300 & 500 & 400 & 520 & 850 & 300 & 700 \\
\hline $\begin{array}{l}\text { Boosting } \\
\text { type }\end{array}$ & None & $\begin{array}{l}\text { Elect. } \\
\text { Lid } \\
\text { Heat }\end{array}$ & $\begin{array}{l}\text { Propane } \\
\text { Combus- } \\
\text { tion }\end{array}$ & $\begin{array}{l}\text { Elect. } \\
\text { Lid } \\
\text { Plasma } \\
\text { Torch }\end{array}$ & None & $\begin{array}{l}\text { Elect. } \\
\text { Lid } \\
\text { Heat }\end{array}$ & None & $\begin{array}{l}\text { Elect. } \\
\text { Lid } \\
\text { Heat }\end{array}$ & $\begin{array}{l}\text { Elect. } \\
\text { Lid } \\
\text { Heat }\end{array}$ & None & $\begin{array}{l}\text { Elect. } \\
\text { Lid } \\
\text { Heat }\end{array}$ \\
\hline $\begin{array}{l}\text { Boost ing } \\
\text { power, kw }\end{array}$ & - & 30 & 35 & 40 & - & 15 & - & 36 & 55 & -- & 45 \\
\hline 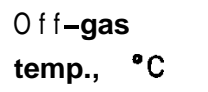 & 375 & 375 & 375 & 400 & 250 & 300 & 275 & 375 & 400 & 270 & 360 \\
\hline $\begin{array}{l}\text { Off-gas } \\
\text { cool lng, } \\
\mathrm{L} / \mathrm{h}\end{array}$ & 0 & 8 & 23 & 24 & 0 & $\begin{array}{l}\text { Var i- } \\
\text { able }\end{array}$ & 0 & 23 & 23 & 0 & 30 \\
\hline $\begin{array}{l}\text { Experiment } \\
\text { duration, } h\end{array}$ & 120 & 120 & 120 & 120 & 125 & 111 & 107 & 99 & 138 & 115 & 232 \\
\hline
\end{tabular}

semivolatile isotopes of radiological concern that are present in typical defense waste. The trace element composition of the SRL feed slurry is presented in Table 3.

Although the waste composition of the liquid feed remained essentially constant throughout the period of testing covered in this report (see Table 2), the rheology of the feed was dramatically affected by the addition of formic acid to the DWPF waste stream. Initial experiments were conducted with an alkaline ( $\mathrm{pH} 11$ to 12) slurry having the physical characteristics of a Bingham plastic fluid. Acidification (to $\mathrm{pH} 5$ to 6 ) of the liquid waste stream with formic acid resulted in slurries which behaved more like an ideal Newtonian fluid. The presence of formic acid in melter feed slurries not only changed 


\section{TABLE 2. Simulated Waste Slurry and Glass Compositions}

\begin{tabular}{|c|c|c|c|c|c|c|c|c|c|}
\hline \multicolumn{4}{|c|}{ Waste Slurry Composition } & \multicolumn{6}{|c|}{ Typical Slurry and Glass Oxide Composition (a) } \\
\hline Alkaline & Vaste & Acidic & Vaste & & ivalent & Xide $\mathrm{Cc}$ & entration, & & Final Glass \\
\hline Compound & $\begin{array}{c}\text { Conc., } \\
\text { g/L }\end{array}$ & Compound & $\begin{array}{l}\text { Conc., } \\
\text { g/L }\end{array}$ & Oxide & $\begin{array}{l}\text { Waste } \\
\text { Sludge } \\
\end{array}$ & $\begin{array}{l}\text { Frit- } \\
131(\mathrm{~b})\end{array}$ & Zeolite $(c)$ & Total & $\begin{array}{c}\text { Composition. } \\
\text { Wt. } \%\end{array}$ \\
\hline Frit-131 & 338.0 & Frit-131 & 341.3 & & & & & & \\
\hline Zeolite & 14.7 & Zeolite & 9.9 & & & & & & \\
\hline Anth. Coal & 3.30 & $\mathrm{HCHO}_{2}$ & 18.0 & & & & & & \\
\hline $\mathrm{Fe}(\mathrm{OH})_{3}$ & 90.9 & $\mathrm{Fe}(\mathrm{OH})_{3}$ & 81.2 & $\mathrm{Fe}_{2} \mathrm{O}_{3}$ & 60.7 & & & 60.7 & 12.7 \\
\hline $\mathrm{Al}(\mathrm{OH})_{3}$ & 21.0 & $\mathrm{Al}(\mathrm{OH})_{3}$ & 34.2 & $\mathrm{Al}_{2} \mathrm{O}_{3}$ & 22.3 & & 1.9 & 24.2 & 5.1 \\
\hline $\mathrm{MnO}_{2}$ & 19.5 & $\mathrm{Mn}\left(\mathrm{CHO}_{2}\right)_{2}$ & 28.2 & MnO & 13.8 & & & 13.8 & 29 \\
\hline $\mathrm{Ni}(\mathrm{OH})_{2}$ & 10.4 & $\mathrm{Ni}\left(\mathrm{CHO}_{2}\right)_{2}$ & 8.3 & NiO & 4.1 & & & 4.1 & 0.8 \\
\hline $\mathrm{CaCO}_{3}$ & 8.90 & $\mathrm{Ca}\left(\mathrm{CHO}_{2}\right)_{2}$ & 16.7 & $\mathrm{CaO}$ & 7.2 & & 1.1 & 8.3 & 1.7 \\
\hline $\mathrm{SiO}_{2}$ & 5.84 & $\mathrm{SiO}_{2}$ & 15.6 & $\mathrm{SiO}_{2}$ & 15.6 & 197.6 & 4.7 & 219.9 & 45.6 \\
\hline $\mathrm{NaOH}$ & 4.93 & $\mathrm{NaCHO}_{2}$ & 8.42 & & & & & & \\
\hline $\mathrm{NaNO}_{3}$ & 2.01 & NaNO & 2.01 & $\mathrm{Na}_{2} \mathrm{O}$ & 4.6 & 60.4 & 0.2 & 65.2 & 13.6 \\
\hline $\mathrm{Na}_{2} \mathrm{SO}_{4}$ & 0.73 & $\mathrm{Na}_{2} \mathrm{SO}_{4}$ & 0.72 & $\mathrm{Na}_{2} \mathrm{SO}_{4}$ & 0.7 & & & 0.7 & 0.1 \\
\hline & & & & $\mathrm{B}_{2} \mathrm{O}_{3}$ & & 50.2 & & 50.2 & 10.5 \\
\hline & & & & $\mathrm{Li}_{2} \mathrm{O}$ & & 19.4 & & 19.4 & 4.1 \\
\hline & & & & MgO & & 6.8 & & 6.8 & 1.4 \\
\hline & & & & $\mathrm{TiO}_{2}$ & & 3.4 & & 3.4 & 0.7 \\
\hline & & & & $\mathrm{La}_{2} \mathrm{O}_{3}$ & & 1.7 & & 1.7 & 0.4 \\
\hline & & & & $\mathrm{ZrO}_{2}$ & & 1.7 & 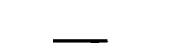 & 1.7 & 0.4 \\
\hline & & & & TOTAL & 129.0 & 341.2 & 7.9 & 480.1 & 100.0 \\
\hline
\end{tabular}

(a) Feed slurry glass content $=0.48 \mathrm{~kg} / \mathrm{L}$.

(b) Frit-131 Composition (-200 mesh).

\begin{tabular}{lcc}
\cline { 1 - 1 } Oxide & & Wt\% \\
$\mathrm{SiO}_{2}$ & & 57.9 \\
$\mathrm{~B}_{2} \mathrm{O}_{3}$ & & 14.7 \\
$\mathrm{Na}_{2} \mathrm{O}$ & & 17.7 \\
$\mathrm{Li}_{2} \mathrm{O}$ & & 5.7 \\
$\mathrm{MgO}$ & & 2.0 \\
$\mathrm{TiO}_{2}$ & & 1.0 \\
$\mathrm{La}_{2} \mathrm{O}_{3}$ & & 0.5 \\
$\mathrm{ZrO}_{2}$ & & 0.5 \\
$\mathrm{TOTAL}$ & 100.0
\end{tabular}

(c) Zeolite Composition: Linde Ionsiv IE-95.

\begin{tabular}{|c|c|}
\hline Component & Wtz \\
\hline $\mathrm{CaAl}_{2} \mathrm{Si}_{4} \mathrm{O}_{12} 6 \mathrm{H}_{2} \mathrm{O}$ & 80 \\
\hline $\mathrm{Na}_{4} \mathrm{Ca}_{1.5} \mathrm{Al}_{3} \mathrm{Si}_{8} \mathrm{O}_{24} 8 \mathrm{H}_{2} \mathrm{O}$ & 20 \\
\hline TOTAL & 100 \\
\hline Assumed Oxide Forms & Wtz \\
\hline $\mathrm{CaO}$ & 10.6 \\
\hline $\mathrm{Al}_{2} \mathrm{O}_{3}$ & 19.2 \\
\hline $\mathrm{SiO}_{2}$ & 47.7 \\
\hline $\mathrm{Na}_{2} \mathrm{O}$ & 2.5 \\
\hline $\mathrm{H}_{2} \mathrm{O}$ & 20.0 \\
\hline TOTAL & 100.0 \\
\hline
\end{tabular}


TABLE 3. Concentration of Trace Additives in Melter Feed

\begin{tabular}{|c|c|c|}
\hline & \multirow{2}{*}{\multicolumn{2}{|c|}{ Concentration, $\mathrm{g} / \mathrm{L}$}} \\
\hline Additives & & \\
\hline $\mathrm{Cs}_{2} \mathrm{O}$ & 0.25 & 0.24 \\
\hline Sr0 & 0.098 & 0.083 \\
\hline $\mathrm{Sb}_{2} \mathrm{O}_{3}$ & 0.16 & 0.060 \\
\hline $\mathrm{SeO}_{2}$ & 0.04 & 0.029 \\
\hline $\mathrm{cdO}$ & 0.38 & 0.033 \\
\hline $\mathrm{TeO}_{2}$ & 0.05 & 0.036 \\
\hline $\mathrm{RuO}_{2}$ & 0.085 & 0.064 \\
\hline
\end{tabular}

the fluidic properties of the feed; it also dramatically influenced the off-gas emission properties of the liquid-fed melter.

\section{EFFLUENT CHARACTERIZATION}

One of the major tasks involved in the DWPF off-gas studies was that of determining melter emission characteristics. The nature and extent of meltergenerated effluents had to be established before off-gas system criteria could be finalized for the DWF melters. Consequently, an off-gas sampling system was developed to provide this basic off-gas design data.

\section{OFF-GAS SAMPLING NETWORK}

The sampling network, which was developed in support of melter emission characterization studies, is schematically illustrated in Figure 2. The

NOTE: In the list of network components on page 8, effluents which could not be used directly appear in parentheses adjacent to chemical analogs which were used to simulate their behavior. 


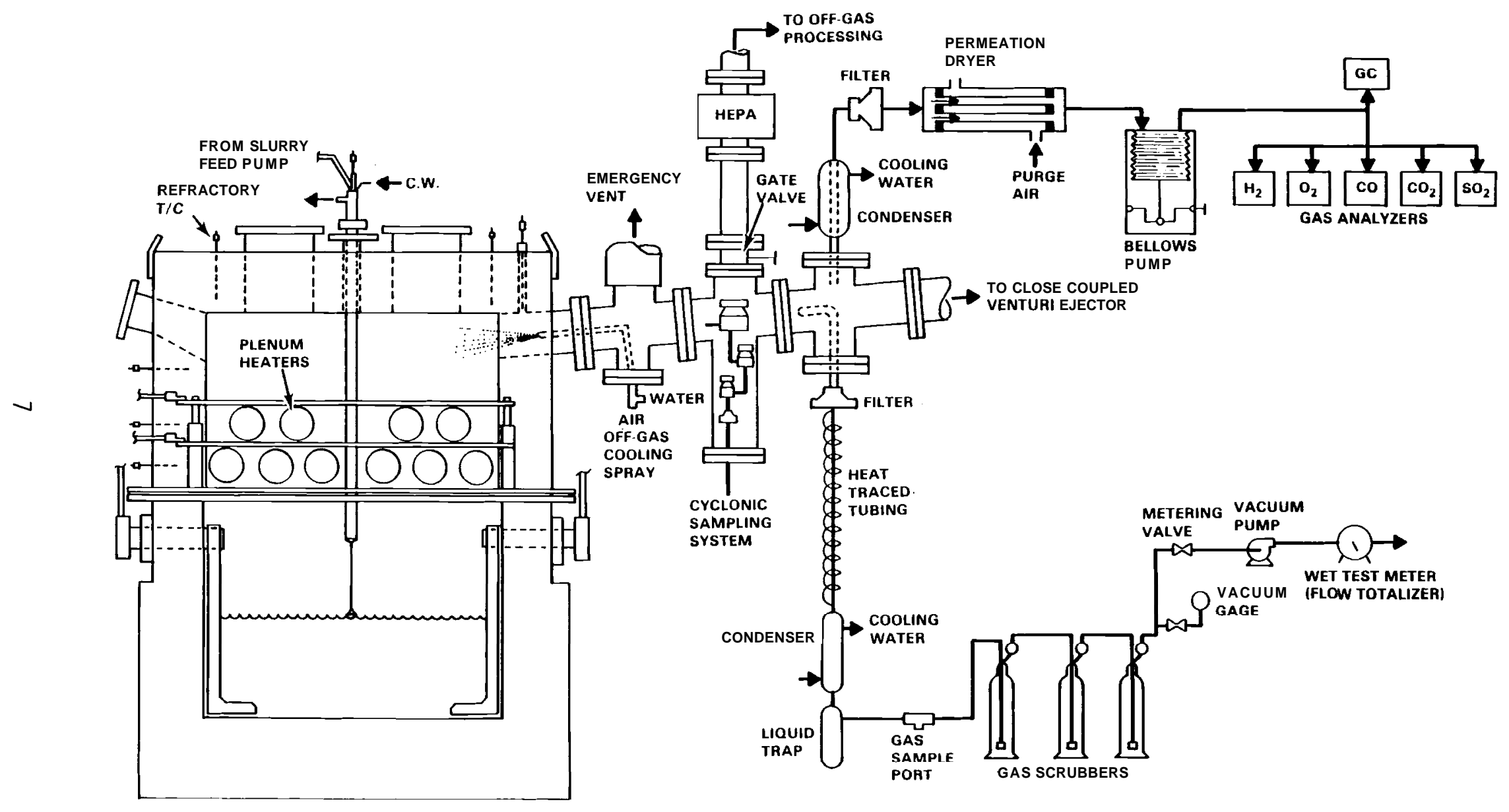

FIGURE 2. Melter Off-Gas Sarnpling Network 
components making up this network were designed to determine the composition of melter exhaust with regard to the effluents listed below.

$\begin{array}{cll}- \text { Gases: } \mathrm{SO}_{2} \text { - Semivolatiles: Halogens } & \text { Particulates } \\ \mathrm{N}_{2} & \mathrm{Sb} \\ \mathrm{O}_{2} & \mathrm{Se} \\ \mathrm{CO} & \mathrm{Te} \\ \mathrm{CO} & \mathrm{Mn}(\mathrm{Tc}) \\ \mathrm{SO}_{2} & \mathrm{Ru} \\ & \mathrm{Cd}(\mathrm{Hg}) \\ & \mathrm{Sr} \\ & \text { Others }\end{array}$

The gaseous composition of melter off-gas emissions was established using a gas chromatograph (GC) and real-time gas analyzers. The gas stream sampled was extracted prior to any off-gas processing. This hot, water-laden gas stream was first passed through a tube and shell condenser, which reduced the water loading of the gas, while minimizing the gaseous interactions with condensed-phase water. The quenched gas stream was then passed through a filter and a permeation dryer, and finally distributed to the individual gas analyzers using a stainless steel bellows pump.

The GC used in these studies is programmed to sample and analyze the composition of the continuously flowing gas stream every $30 \mathrm{~min}$. The gaseous components routinely quantified by this instrument include $\mathrm{O}_{2}, \mathrm{~N}_{2}, \mathrm{CO}$, and $\mathrm{CO}_{2}$. In addition, the GC provides semi-quantitative information with regard to gaseous concentrations of $\mathrm{H}_{2}$ and $\mathrm{SO}_{2}$.

Real-time measurements of melter noncondensible gas concentrations were initiated during the latter part of this study with five continuous gas monitors. These instruments have provided continuous off-gas data on the concentrations of $\mathrm{H}_{2}, \mathrm{O}_{2}, \mathrm{CO}, \mathrm{CO}_{2}$, and $\mathrm{SO}_{2}$ for all melter tests following PSCM-4.

The pathways and magnitudes of melter-generated semivolatile emissions were assessed using a differential sampling system composed of a filter, a 
heat-traced sampling line, a condenser, and a series arrangement of three gas scrubbing units (Figure 2). The distribution of semivolatiles across the five discrete sample fractions generated by the system were determined using emission spectrometry (ICP), atomic absorption (AA), ion chromatography (IC), and $X$-ray fluorescence (XRF). Al1 semivolatile studies have been exclusively concerned with characterizing the composition of the unquenched melter exhaust.

The concentration, size and composition of melter-generated aerosols were also characterized. Total off-gas particulate loading was established yravimetrically by HEPA filtration of the entire melter off-gas stream (Figure 2). Particle size information was obtained from a cyclonic sampling system consisting of a series arrangement of three cyclones and a final absolute filter. The cut points of the cyclones employed were $16 \mu \mathrm{m}, 6 \mu \mathrm{m}$, and $1 \mu \mathrm{m}$ at 18 actual $\mathrm{L} / \mathrm{min}$. The final absolute filter was designed to collect submicron fines which are able to pass through all three preceding cyclones. The elemental composition of the particulate matter collected by these sampling devices was established using ICP, $A A$, and IC.

\section{EXHAUST COMPOSITION}

The noncondensible $\left(20^{\circ} \mathrm{C}\right)$ yases generated by liquid-fed melters are dependent upon slurry feed composition as well as melter operating conditions. The alkaline waste feed used during the initial stages of this study possessed very low concentrations of organic matter. Consequently, the gross off-gas composition was essentially $\mathrm{CO}_{2}$-enriched inleakage. The emission rates of the combustible gas $\mathrm{CO}$ during all of the alkaline feed tests were always less than $1 / 10$ the rate associated with $\mathrm{CO}_{2}$. Table 4 summarizes the average gross compositional data associated with alkaline-feed melter exhausts.

The dramatic difference between the PSCM-2 data and the other experiments listed in Table 4 is due to the method of boosting used in that test. During PSCM-2, a propane torch supplied supplemental heat to the melter plenum to increase the feeding rates. Consequently, the major source of off-gas combustion products was the boosting torch and not the melter. Figure 3 illustrates the time-correlated behavior of the melter exhaust duriny PSCM-2. The relationships illustrated are consistent with the propane combustion process. 
TABLE 4. Melter Noncondensible Off-Gas Composition (basic waste)

\begin{tabular}{|c|c|c|c|c|c|c|c|c|c|c|c|c|c|}
\hline \multirow[b]{3}{*}{ Experiment } & \multirow{3}{*}{$\begin{array}{c}\text { Melter } \\
\text { In leakage, } \\
\text { scfm }\end{array}$} & \multicolumn{12}{|c|}{ Molar \& } \\
\hline & & \multicolumn{3}{|c|}{$\infty$} & \multicolumn{3}{|c|}{$\mathrm{CO}$} & \multicolumn{3}{|c|}{0} & \multicolumn{3}{|c|}{$\mathrm{N}_{2}$} \\
\hline & & $\mathrm{High}$ & $\overrightarrow{A v g}$ & Low & High & Avg & Low & High & Avg & Low & High & Avg & Low \\
\hline PSCM-1 & $5-10$ & 6.4 & 3.4 & 18 & 0.01 & - & - & 20 & 14.0 & 7.1 & 89 & 81 & 73 \\
\hline LCCM-4 & 32 & 1.1 & 0.58 & 0.40 & 0.03 & 0.02 & 0.001 & 21 & 20.5 & 20.0 & 78 & 78 & 78 \\
\hline PSCM-2 & 45 & 8.6 & 4.6 & 0.20 & 3.0 & 0.50 & 0.001 & 21 & 14.0 & 8.0 & 82 & 80 & 79 \\
\hline LFCM-6 & 29 & 0.87 & 0.54 & 0.13 & 0.07 & 0.02 & 0.001 & 20 & 20.0 & 18.0 & 80 & 79 & 78 \\
\hline
\end{tabular}

The composition of melter-generated, noncondensible gases was dramatically affected when formic acid was added to the simulated melter feed. This compositional alteration increased the organic loading in the melter feed by approximately an order of magnitude. Consequently, melter exhaust gases were of particular interest during these acidified feed tests due to the possibility of generating enough $\mathrm{H}_{2}$ and $\mathrm{CO}$ (water gas) to present a flammability hazard after off-gas quenching.

Figure 4 illustrates the time-related behavior of gross me1ter exhaust gases during a 120 -h melter test which employed $100 \mathrm{~h}$ of radiant I id heat boosting followed by $20 \mathrm{~h}$ of unboosted operation. The presence of plenum heaters during liquid feeding clearly reduced melter emissions of the combustible gases $\mathrm{H}_{2}$ and $\mathrm{CO}$. With the termination of lid heating, the melter plenum cooled, reducing the oxidation rates of these gases sufficiently to allow significant quantities of each gas to escape the plenum through the off-gas system. This result is quite reproducible; however, virtual elimination of combustible gas emissions during boosting,' as is illustrated in Figure 4, may not always be achievable.

Similarly, the concentrations of combustibles leaving an unboosted melter may be significantly higher than indicated in Figure 4 since these concentrations are slurry composition-, temperature-, feed-, and inleakage-ratedependent variables. Indeed, dilution air was required during the unboosted PSCM-7 test to reduce $\mathrm{H}_{2}$ in the quenched off-gas stream to below $70 \%$ of its lower inflammability $1 \mathrm{imit}(-4 \%)$. A summary of the gaseous concentrations of organic decomposition and reaction products generated during all formate feed testing is presented in Table 5, along with average melter inleakage rates. 


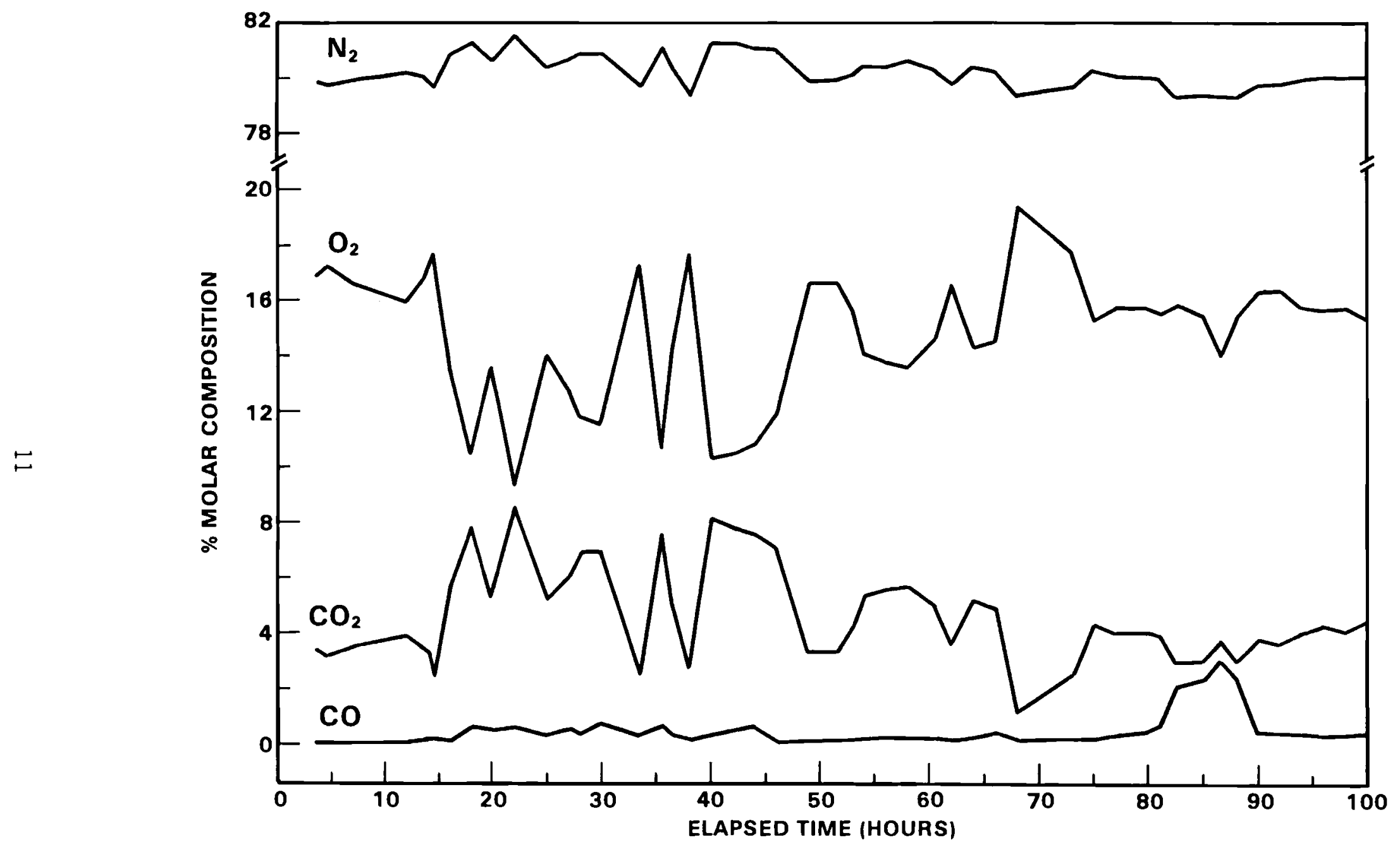

FIGURE 3. Composition of Combustion Boosted Melter Exhaust 


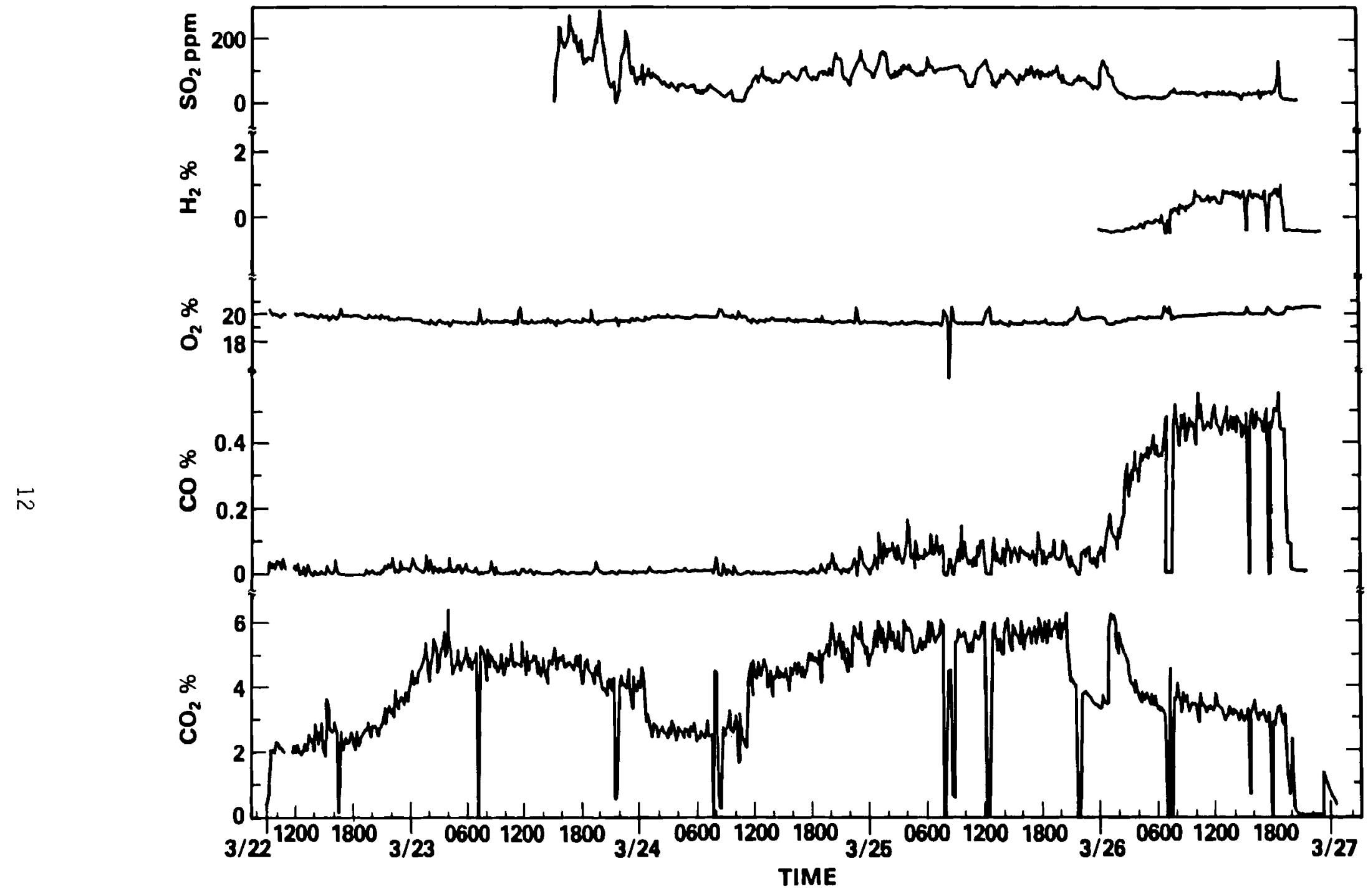

FIGURE 4. Melter Exhaust Gas Composition of a 100-h Boosted, 20-h Unboosted Test 
TABLE 5. Melter-Generated $0 \mathrm{ff-Gas} \mathrm{Components} \mathrm{(acid} \mathrm{waste)}$

\begin{tabular}{|c|c|c|c|c|c|c|c|c|c|c|}
\hline \multirow[b]{3}{*}{ Experiment } & \multirow{3}{*}{$\begin{array}{c}\text { Melt e r } \\
\text { In leakage, } \\
\text { scfm }\end{array}$} & \multicolumn{9}{|c|}{ Molar $\mathrm{X}$} \\
\hline & & \multicolumn{3}{|c|}{$\infty$} & \multicolumn{3}{|c|}{$\mathrm{CO}$} & \multicolumn{3}{|c|}{$\mathrm{H}_{2}$} \\
\hline & & High & Avg $^{-}$ & Low & High & Avg & Low & High & Avg & Low \\
\hline $\operatorname{PSCM}-3^{(a)}$ & 20 & 29 & 13 & 026 & 1.3 & 0.40 & 0.04 & 1.11 & NA & 0.17 \\
\hline LFCM-7 & 90 & 2.2 & 0.74 & 0.03 & 0.44 & 0.13 & 0.002 & 0.63 & 0.54 & 0.40 \\
\hline PSCM-4 & 20 & 4.4 & 2.9 & 1.5 & 0.75 & 0.44 & 0.20 & 1.3 & 1.1 & 0.94 \\
\hline PSCM-5 & 30 & 6.5 & 2.8 & 2.0 & 0.90 & 0.35 & 0.10 & 1.8 & 0.80 & 0.10 \\
\hline PSCM-6 & 30 & 6.5 & 4.1 & 2.0 & 0.60 & 0.09 & 0.005 & 1.2 & NA & 0.05 \\
\hline PSCM-7 & $12^{(b)}$ & 8.0 & 5.0 & 1.5 & 1.2 & 0.75 & 0.10 & 3.5 & 1.9 & 0.30 \\
\hline PSCM-8 & 14 & 9.3 & 6.1 & 1.2 & 0.8 & 0.16 & $<0.005$ & NA & NA & NA \\
\hline
\end{tabular}

(a) Sample stream diluted -25 times.

(b) Off-gas dilution was used.

The off-gas data presented in Figure 4 illustrates that melter emissions are not generated smoothly or continuously even under the most controlled operational conditions. This behavior is due to the erratic, nonuniform way in which melter feed is dried, oxidized, and melted during the liquid feeding process. Large variations in gas generation rates usually occur when dammed-up liquid feed lying atop an insulating layer of dry feed (the cold cap) abruptly flows out upon a hot glass surface. The liquid quickly flashes off this hot surface, producing a flow pulse composed of steam and volatile organic reaction products.

Figure 5 illustrates the behavior of some of the more important meltergenerated gases accompanying flow surges. The frequency and magnitude of these surges are positive indicators of melter system instabilities, which are most often associated with erratic or excessive feeding.

The correlation between the emission rates of noncondensible gases and steam flow surges suggests that the evolution of combustible gases from the cold cap is quite prompt. Figure 6 portrays the time-dependent compositional behavior of the melter exhaust stream upon feed interruption or termination. With the exception of $\mathrm{SO}_{2}$, none of the melter-generated gases increased in concentration when feeding was terminated. This fact implies that volatile 


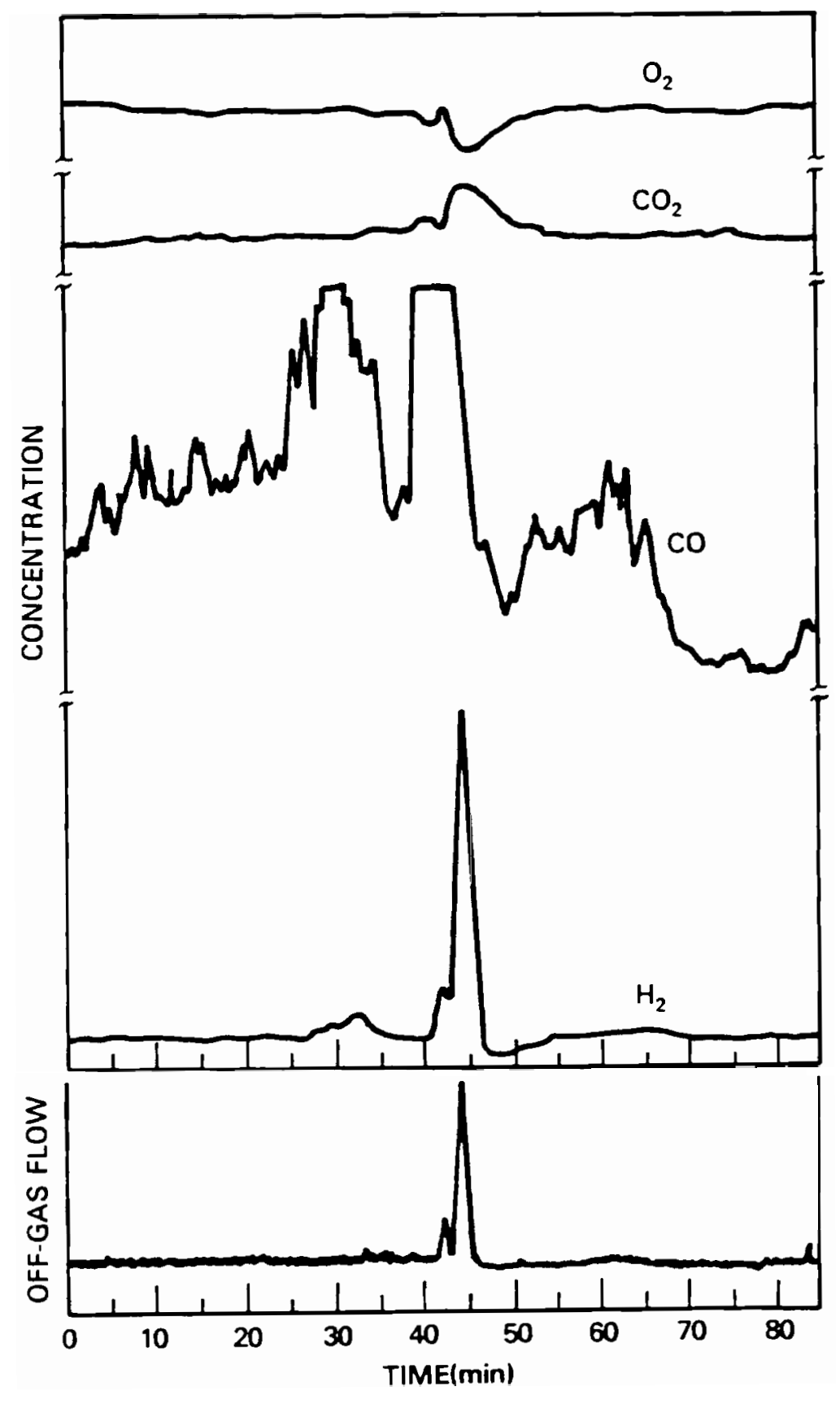

FIGURE 5. Compositional Behavior of Noncondensible Melter Exhaust Gases Acconipanyiny a Flow Surge. (Maximum extent of the surge event: flow-3X; $\mathrm{H}_{2}<3.5 \% ; \mathrm{CO}>>0.5 \% ; \mathrm{CO}_{2}-15 \% ; \mathrm{O}_{2}-17 \%$.) 


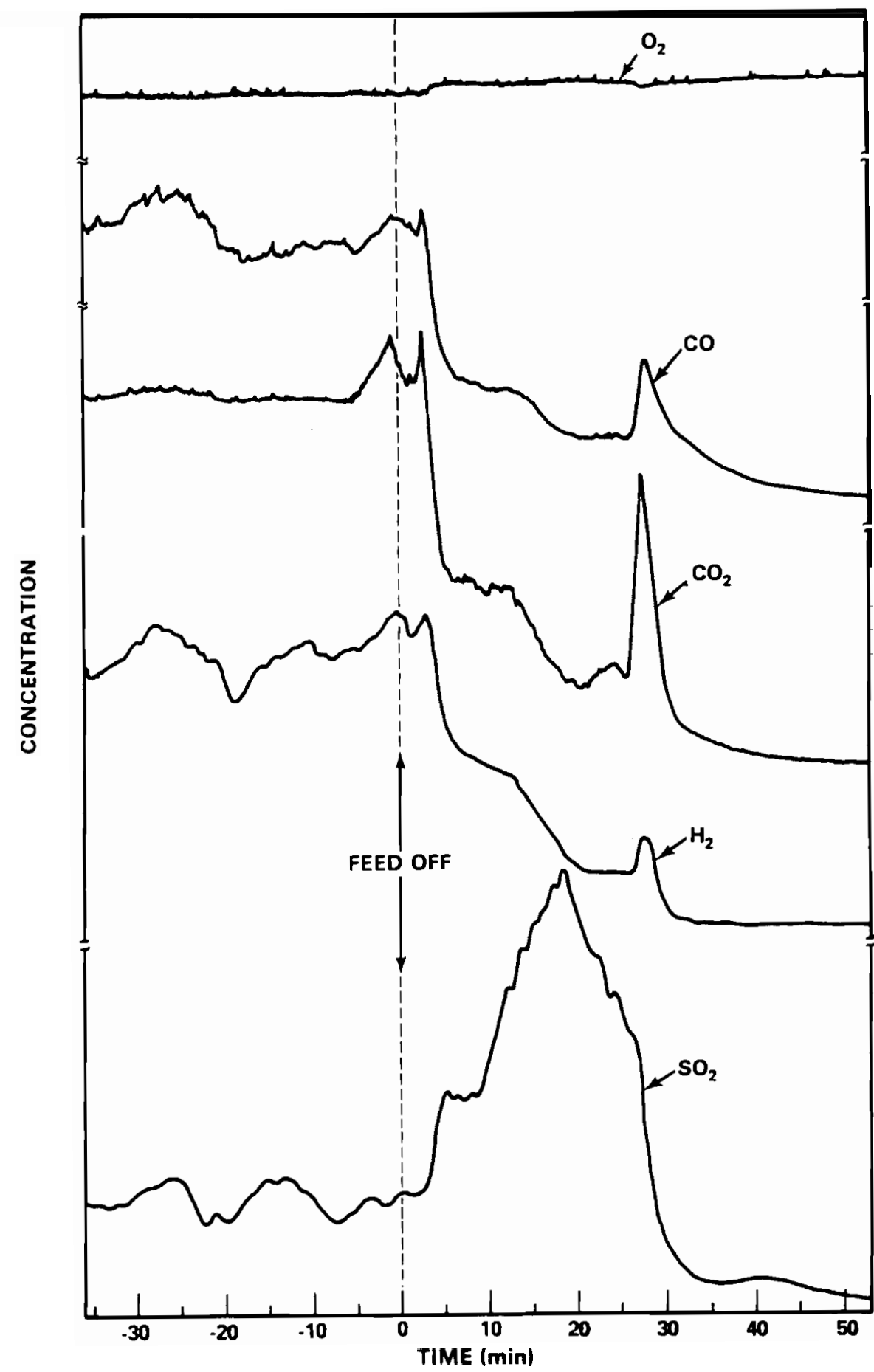

FIGURE 6. Melter Off-Gas Compositional Behavior Associated with Feed Termination. (The $\mathbf{t}=30 \mathrm{~min}$ compositional spike is due to the injection of a small quantity of liquid feed.) 
decomposition and reaction products generated from the melter feed are formed soon after introduction of the feed into the melter. Consequently, significant accumulations of chemically reactive, organic feed components within the melter cold cap apparently do not occur under steady-state feeding conditions.

On the other hand, the increase in terminal $\mathrm{SO}_{2}$ exhaust concentration (illustrated in Figure 6) suggests that sulfur, as $\mathrm{Na}_{2} \mathrm{SO}_{4}$, may be accumulating within the melter as a molten salt. This was indeed the case, as post-run inspection of the idling melter glass surface later proved. This observation stimulated speculation that accumulations of $\mathrm{Na}_{2} \mathrm{SO}_{4}$ could be responsible for changes in the melting capacity of liquid-fed melters that occur during the initial 24 hours of liquid feeding (the startup phase).

Melter emission characteristics of $\mathrm{SO}_{2}$ further support this notion, as is shown in Figure 7. During the initial startup phase, when the melter's ability to handle feed is limited, feed-rate-normalized $\mathrm{SO}_{2}$ emission rates are uncharacteristically low, indicating that $\mathrm{Na}_{2} \mathrm{SO}_{4}$ is probably accumulating. As processing continues at a fixed feeding rate, $\mathrm{SO}_{2}$ emission rates gradually increase along with the melting capacity of the liquid-fed melter. It is known (Conroy, Manning and Bauer 1966) that the presence of a molten $\mathrm{Na}_{2} \mathrm{SO}_{4}$ phase within a ceramic melter will increase the heat transfer rate between the molten glass and the feed, thereby boosting melting capacity. All of the above mentioned liquid-fed melter characteristics are consistent with this fact.

Although Figure 7 suggests that $\mathrm{SO}_{2}$ evolution is an important mechanism responsible for sulfur melter feed losses, this is true only for boosted experiments where plenum temperatures are greater than $700^{\circ} \mathrm{C}$. Emission rates of $\mathrm{SO}_{2}$ during unboosted runs are at least an order of magnitude lower than when boosting techniques are employed. However, total melter losses of sulfur are independent of boosting, indicating the presence of other volatile chemical channels of escape $\left(\mathrm{SO}_{3}\right)$. Filtered gas-scrubbing techniques have further verified that significant concentrations of acidic volatile gases of sulfur, as well as the halogens, always exist in unquenched melter exhaust streams independent of melter operating conditions. This subject will be developed further in discussions that follow. 

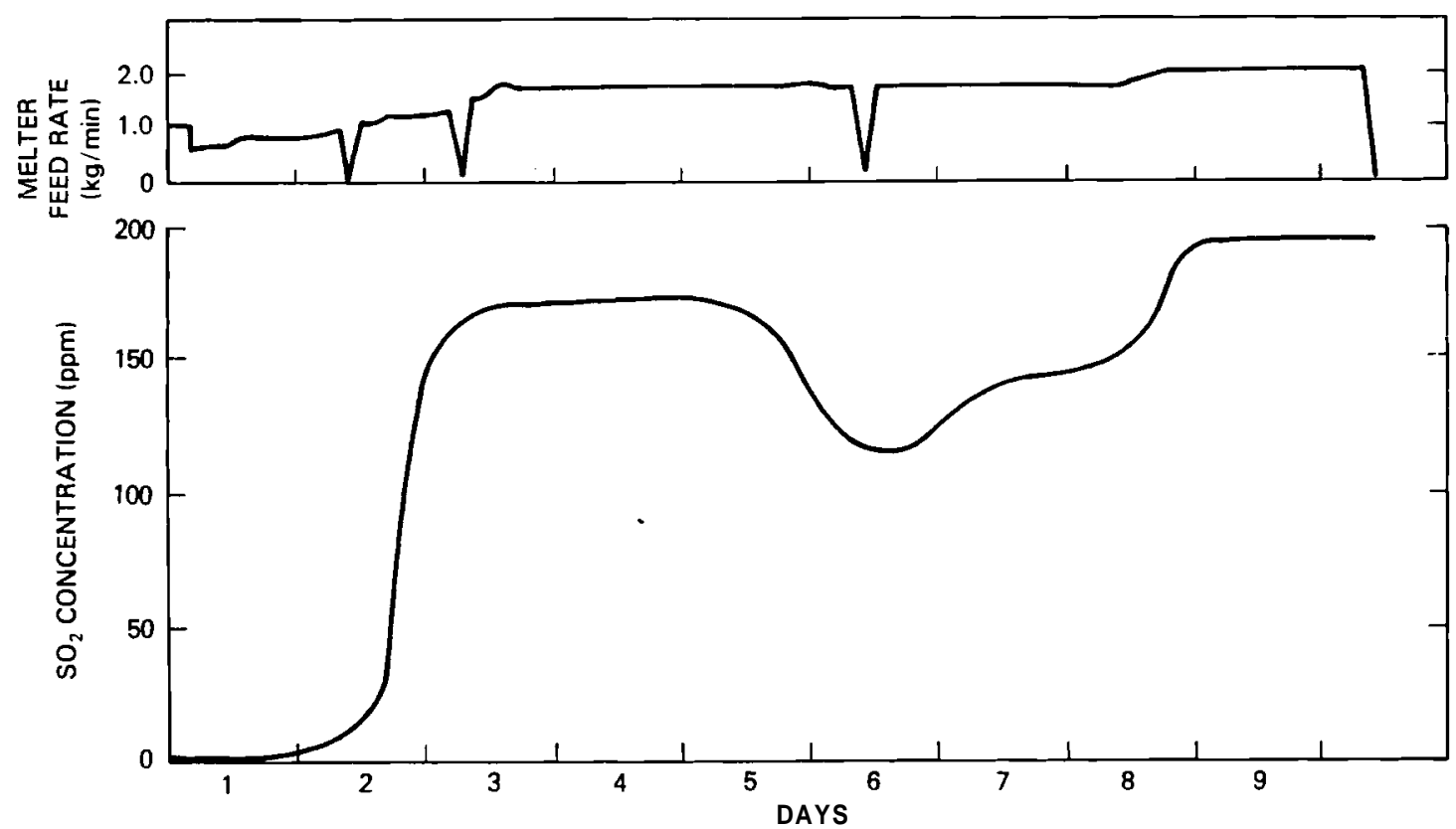

FIGURE 7. Melter $\mathrm{SO}_{2}$ Emission Characteristics Accompanying a 240-h Test

\section{NATURE OF MELTER FEED COMPONENT LOSSES}

In order to characterize the pathways and magnitudes of melter feed component losses, a differential sampling system composed of an aerosol filter, condenser, and a series arrangement of three gas-scrubbing units was employed. The manner in which any given element is distributed across the five discrete sampling fractions of this device is indicative of the physical state(s) assumed by the effluent. Typical data generated with this differential sampling system during a formate-feed melter test are summarized in Table 6 . The values 1 isted in this table are melter decontamination factors (DFs), which are ratios of the rate at which feed components enter the melter to the rate at which they are evolved. Particulate DFs are partial DFs relating to only a single loss mechanism: aerosol emission. The data presented in this abridged table clearly show that rnelter gas-phase losses to the off-gas system are only significant for $\mathrm{Cl}, \mathrm{S}$, and $\mathrm{B}$, which readily form volatile acid gases previously referred to.

This is not to say that melter-induced volatilization has no influence upon melter losses of other feed component elements. On the contrary, the low 
TABLE 6. PSCM-6 Particulate and Total Feed Component DFs

\begin{tabular}{|c|c|c|}
\hline \multirow[b]{2}{*}{ Element } & \multicolumn{2}{|c|}{ Average DF } \\
\hline & Particulate & Total \\
\hline $\mathrm{A} 1$ & 27,000 & 22,000 \\
\hline B & 6,800 & 100 \\
\hline $\mathrm{Cd}$ & 9.9 & 9.9 \\
\hline C1 & 21 & 2.9 \\
\hline Cs & 14 & 14 \\
\hline $\mathrm{Fe}$ & 1,900 & 1,800 \\
\hline La & 2,100 & 2,100 \\
\hline $\mathrm{Mn}$ & 1,800 & 1,800 \\
\hline $\mathrm{Na}$ & 300 & 300 \\
\hline S & 11 & 5.5 \\
\hline $\mathrm{Sr}$ & 1,800 & 1,800 \\
\hline $\mathrm{Te}$ & 3.0 & 3.0 \\
\hline $\mathrm{Zr}$ & 22,000 & 22,000 \\
\hline
\end{tabular}

DFs associated with the semivolatile elements Cd, Cs, and Te, as well as Se and $\mathrm{Sb}$, clearly underscore the importance of this volatilization process. What is being said is that apart from the mechanisms responsible for producing airborne effluents, particulate transport through the off-gas system is the predominant loss mechanism associated with liquid-fed melter operation.

\section{CHARACTERISTICS OF MELTEK AEROSOLS}

Since most melter off-gas system losses are associated with aerosol emission, establishing the characteristics of these aerosols was of particular interest. The size distribution of melter-generated aerosols was established using a cyclonic particle-size analysis system, which was described earlier. Table 7 details the manner in which melter particulate matter was distributed across the cyclonic sample fractions for different melter experiments. A11 melter tests, with the exception of PSCM-4, exhibited aerosol-size distributions which were bimodal. This suggests that the overall aerosol distribution may be comprised of two independent components, each having its own characteristic size distribution. Gross compositional dissimilarities between the 
TABLE 7. Size Distribution of Melter Aerosols

\begin{tabular}{|c|c|c|c|c|}
\hline & \multicolumn{3}{|c|}{ Average wt $\%$ Versus Cut } & Point \\
\hline Experiment & $16 \mu \mathrm{m}$ & 6 & $1 \mu \mathrm{m}$ & $\leq 1 \mu \mathrm{m}$ \\
\hline LFCM-7 & 76.7 & 2.8 & 8.5 & 11.9 \\
\hline PSCM-4 & -- & 0.9 & 3.6 & 95.6 \\
\hline PSCM-5 & 13.5 & 3.9 & 20.2 & 62.2 \\
\hline PSCM-6 & 46.1 & 0.5 & 12.7 & 40.7 \\
\hline PSCM-7 & 7.5 & 3.2 & 9.4 & 79.9 \\
\hline PSCM-8 & 44.0 & 7.3 & 19.6 & 29.1 \\
\hline
\end{tabular}

discrete cyclonic size fractions illustrated in Table 8 strongly reinforce this argument. Moreover, since the submicron size fraction detailed in this table (LFCM-7) contains only $12 \%$ of the total sample mass, but possesses essentially all the semivolatile matter of the sample, the mechanism responsible for the small-diameter component of the overall distribution is probably a volatilization/condensation process that occurs within the melter plenum. The compositions of the large cyclonic size fractions are very similar to those of the slurry feed as shown in Table 9. Consequently, the large component of the bimodal distribution must be associated with a gross entrainment mechanism.

Since the major melter loss mechanism associated with the radiologically important semivolatiles is associated with submicron aerosol emission, the elemental makeup of this size fraction is of particular interest. Table 10 presents representative submicron particulate compositional data collected during the PSCM-4 experiment. If a material balance for this submicron matter is established by assuming an oxide form'for all elements except for a stoichiometric quantity of $\mathrm{Na}$, which is associated with the $\mathrm{Cl}$ in the sample, $99 \%$ of the matter present can be accounted for. It should be noted that while the submicron sample fraction is quite rich in semivolatiles, it is essentially salt $(83 \mathrm{wt} \% \mathrm{NaCl})$.

\section{MELTER EMISSION PERFORMANCE}

Melter performance with regard to effluent emission is commonly expressed in terms of a unitless decontamination factor, or DF. By definition, a melter 
TABLE 8. Elemental Distribution Across the Cyclonic Sampling System

\begin{tabular}{|c|c|c|c|c|}
\hline \multirow[b]{2}{*}{ Element } & \multicolumn{4}{|c|}{ Distribution, \% } \\
\hline & $16 \mu \mathrm{m}$ & $6 \mu \mathrm{m}$ & $1 \mu \mathrm{m}$ & $<1 \mu \mathrm{m}$ \\
\hline A1 & 96.2 & 0.9 & 2.5 & 0.4 \\
\hline B & 87.8 & 1.8 & 7.8 & 2.6 \\
\hline $\mathrm{Ba}$ & 83.7 & 5.8 & 10.5 & 0 \\
\hline $\mathrm{Ca}$ & 77.7 & 2.7 & 15.2 & 4.4 \\
\hline $\mathrm{Cd}$ & 10.7 & 0.8 & 7.3 & 81.2 \\
\hline $\mathrm{Ce}$ & 92.1 & 0 & 7.9 & 0 \\
\hline $\mathrm{Cr}$ & 46.4 & 21.7 & 23.3 & 8.6 \\
\hline Cs & 7.5 & 0 & 5.4 & 87.1 \\
\hline $\mathrm{Cu}$ & 82.6 & 4.9 & 4.2 & 8.3 \\
\hline $\mathrm{Fe}$ & 77.3 & 2.6 & 17.0 & 3.1 \\
\hline $\mathrm{La}$ & 91.9 & 1.5 & 6.1 & 0.5 \\
\hline $\mathrm{Li}$ & 83.2 & 1.5 & 5.3 & 10.0 \\
\hline $\mathrm{Mg}$ & 91.5 & 1.6 & 5.8 & 1.1 \\
\hline $\mathrm{Mn}$ & 89.4 & 6.4 & 3.6 & 0.6 \\
\hline Mo & 77.5 & 5.6 & 9.8 & 7.1 \\
\hline $\mathrm{Na}$ & 68.8 & 1.7 & 5.6 & 23.9 \\
\hline $\mathrm{Nd}$ & 93.4 & 0 & 6.6 & 0 \\
\hline $\mathrm{Sb}$ & 100.0 & 0 & 0 & 0 \\
\hline $\mathrm{Se}$ & 56.9 & 1.9 & 11.4 & 29.8 \\
\hline$S \mathbf{i}$ & 92.0 & 1.8 & 5.6 & 0.6 \\
\hline$S r$ & 77.6 & 2.8 & 19.6 & 0 \\
\hline $\mathrm{Te}$ & 5.5 & 0.4 & 3.2 & 90.9 \\
\hline $\mathrm{Ti}$ & 91.2 & 1.8 & 6.0 & 1.0 \\
\hline $\mathrm{Zr}$ & 91.6 & 1.6 & 5.6 & 1.2 \\
\hline
\end{tabular}

feed component DF is the ratio of the rate at which that particular feed component enters the melter to the rate at which it exists. Consequently, melter DFs are related to the liquid-fed melter process efficiencies for converting feed components into a borosilicate glass. Table 11 presents experimental feed component DFs for all pertinent DWPF melter tests conducted at PNL. The entries in this table are grouped according to feed type, and each group is 
TABLE 9. Composition of $16 \mu \mathrm{m}$ Cyclonic Sample Fraction

\begin{tabular}{ccrrr}
$\begin{array}{c}\text { Elemental } \\
\text { Oxides }\end{array}$ & & Weight & Percent \\
\cline { 1 - 1 } $\mathrm{Al}_{2} \mathrm{O}_{3}$ & & $\frac{16 \mu m}{3.4}$ & $\frac{\text { Feed }}{5.1}$ \\
$\mathrm{~B}_{2} \mathrm{O}_{3}$ & & 9.0 & 10.5 \\
$\mathrm{CaO}$ & & 1.6 & 1.7 \\
$\mathrm{Fe}_{2} \mathrm{O}_{3}$ & & 14.4 & 12.7 \\
$\mathrm{La}_{2} \mathrm{O}_{3}$ & & 0.3 & 0.4 \\
$\mathrm{LiO}_{2}$ & & 3.5 & 4.1 \\
$\mathrm{MgO}$ & & 1.1 & 1.4 \\
$\mathrm{MnO}$ & & 3.2 & 2.9 \\
$\mathrm{Na}_{2} \mathrm{O}$ & & 13.0 & 13.6 \\
$\mathrm{SiO}_{2}$ & & 38.0 & 45.6 \\
$\mathrm{TiO}_{2}$ & & 0.7 & 0.7 \\
$\mathrm{ZrO}_{2}$ & & 0.3 & 0.4
\end{tabular}

ordered with respect to the experimental melter employed. This ordering is significant in the interpretation of the data.

The initial melter tests conducted with alkaline feed were, with one exception, all boosted experiments (see Table 1). Consequently, a major goal of all of these tests was to establish maximum melter feeding rates under a variety of plenum heating conditions. To complicate matters, a slurry feed system being developed during this same period was often responsible for inconsistent feed delivery to the melter. As a result, stable steady-state operating conditions during these early melter scoping tests were rarely, if ever, achieved. The spread in melter emission performance data during this initial testing phase is in large part a reflection of the unequilibrated conditions that existed when this data was collected. The average DFs listed for the alkaline feed components should, however, provide a fairly representative description of the ceramic melter effluent emission behavior that occurred during this initial development period.

With the exception of the LFCM-7 test (melter capacity scoping study), all acid feed melter experiments sought to establish operational stability under a 
TABLE 10. Submicron Particulate Composition

\begin{tabular}{|c|c|c|c|c|}
\hline Element & $\begin{array}{c}\text { Elemental } \\
w t \%\end{array}$ & $\begin{array}{l}\text { Assumed } \\
\text { Form } \\
\end{array}$ & $\begin{array}{c}\text { Compound, } \\
\text { wt } \%\end{array}$ & $\begin{array}{c}\text { Feed } \\
\text { Composition, \% } \\
\end{array}$ \\
\hline A1 & 0.04 & $\mathrm{Al}_{2} \mathrm{O}_{3}$ & 0.08 & 4.95 \\
\hline B & 0.07 & $\mathrm{~B}_{2} \mathrm{O}_{3}$ & 0.24 & 9.86 \\
\hline $\mathrm{Ca}$ & 0.14 & $\mathrm{CaO}$ & 0.20 & 1.66 \\
\hline $\mathrm{Cd}$ & 0.55 & $\mathrm{CdO}$ & 0.63 & 0.006 \\
\hline $\mathrm{Cl}$ & 55.0 & -- & -- & 0.4 \\
\hline Cs & 2.1 & $\mathrm{Cs}_{2} \mathrm{O}$ & 2.2 & 0.044 \\
\hline $\mathrm{Cu}$ & 0.06 & $\mathrm{CuO}$ & 0.09 & -- \\
\hline $\mathrm{Fe}$ & 0.29 & $\mathrm{Fe}_{2} \mathrm{O}_{3}$ & 0.41 & 13.69 \\
\hline K & 0.36 & $\mathrm{~K}_{2} \mathrm{O}$ & 0.43 & -- \\
\hline Li & 1.1 & $\mathrm{Li}_{2} \mathrm{O}$ & 2.4 & 3.98 \\
\hline $\mathrm{Mg}$ & 0.02 & $\mathrm{MgO}$ & 0.03 & 1.29 \\
\hline Mn & 0.08 & $\mathrm{MnO}_{2}$ & 0.13 & 3.25 \\
\hline $\mathrm{Na}$ & 33.7 & $\begin{array}{l}\mathrm{NaCl} 1 \\
\mathrm{Na}_{2} \mathrm{O}\end{array}$ & $\begin{array}{r}83.0 \\
6.7\end{array}$ & $13 . \overline{88}$ \\
\hline $\mathrm{Ni}$ & 0.03 & $\mathrm{NiO}$ & 0.04 & 0.76 \\
\hline $\mathrm{Pb}$ & 0.04 & PbO & 0.05 & -- \\
\hline Si & 0.66 & $\mathrm{SiO}_{2}$ & 1.4 & 44.47 \\
\hline $\mathrm{Te}$ & 0.56 & $\mathrm{TeO}_{2}$ & 0.71 & 0.006 \\
\hline $\mathrm{Zn}$ & 0.02 & $\mathrm{ZnO}$ & $\underline{0.02}$ & -- \\
\hline TOTAL & & & 98.8 & \\
\hline
\end{tabular}

variety of run conditions. Table 12 presents partial melter DFs associated with off-gas aerosol emission for the PSCM-5 and PSCM-6 experiments. The data were collected over several days of stable, steady-state melter operation using three independent sampling devices. The internal agreement between results obtained in each test is indicative of the stability associated with each of these experiments. Consequently, eff luent results of individual acid feed experiments should be more representative of average melter behavior than were those associated with the alkaline feed. 
TABLE 11. Melter Effluent Emission Characteristics

\begin{tabular}{|c|c|c|c|c|c|c|c|c|c|c|c|c|c|}
\hline \multirow[b]{2}{*}{ Element } & \multicolumn{5}{|c|}{ Alkaline Feed Meiter DFs } & \multicolumn{8}{|c|}{ Acid Feed Melter DFs ${ }^{(a)}$} \\
\hline & PSCM-1 & LFCM-4 & PSCM-2 & LFCM-6 & Average & LFCM-7 & PSCM-3 & PSCM-4 & PSCM-5 & PSCM-6 ${ }^{(a)}$ & PSCM-7 & PSCM-8 ${ }^{(b)}$ & Avg. \\
\hline Al & 11000 & 530 & 990 & 330 & 3200 & 190 & 6000 & 23000 & 14000 & 22000 & 26000 & 2200 & 13000 \\
\hline B & 210 & 130 & 160 & 90 & 150 & 75 & 200 & 230 & 140 & 100 & 210 & 390 & 190 \\
\hline $\mathrm{Ca}$ & 1840 & 260 & 610 & 180 & 720 & 62 & 1100 & 1900 & 1100 & 1200 & 2600 & 340 & 1200 \\
\hline $\mathrm{Cd}$ & 190 & 70 & 47 & 80 & 100 & 8.0 & -- & 9.2 & 5.7 & 9.9 & 6.5 & 5.6 & 7.5 \\
\hline $\mathrm{Cl}$ & 3.1 & 2.2 & 3 & 2.7 & 2.8 & -- & 4 & 5 & 1.5 & 2.9 & 6.4 & 4.7 & 4.1 \\
\hline Cs & 51 & 57 & 3 & 10 & 30 & 12 & 3.8 & 16 & 9.4 & 14 & 13 & 130 & 28 \\
\hline $\mathrm{Fe}$ & 3800 & 260 & 680 & 230 & 1200 & 69 & 1600 & 2000 & 1100 & 1800 & 2800 & 570 & 1400 \\
\hline $\mathrm{La}$ & -- & - & -- & - & -- & -- & - & - & 10000 & 2100 & 3600 & 590 & 4100 \\
\hline Li & 1900 & 310 & 340 & 160 & 680 & 89 & 2600 & 3200 & 730 & 1300 & 1100 & 1600 & 1500 \\
\hline $\mathrm{Mg}$ & 9000 & 350 & 920 & 260 & 2600 & 120 & 8200 & -- & 3500 & 7800 & 11000 & 1600 & 5400 \\
\hline $\mathrm{Mh}$ & 5700 & 420 & 630 & 330 & 1800 & 76 & 3300 & 2100 & 7100 & 1800 & 3700 & 600 & 2700 \\
\hline $\mathrm{Na}$ & 830 & 340 & 130 & 90 & 350 & 60 & 900 & 180 & 160 & 300 & 290 & 710 & 370 \\
\hline $\mathrm{Nd}$ & -- & -- & -- & -- & -- & -- & -- & -- & -- & 2500 & 4100 & 540 & 2400 \\
\hline $\mathrm{NI}$ & 1500 & 260 & -- & 930 & 900 & -- & 9400 & 1400 & 580 & 1100 & 3100 & 4000 & 3300 \\
\hline $\mathrm{Ru}$ & 32 & 26 & 48 & 13 & 30 & 16 & -- & - & -- & -- & - & -- & -- \\
\hline$S$ & 1 & 1 & 19 & 11 & 8 & -- & 8 & 16 & 4.5 & 5.5 & 2.9 & 10 & 7.8 \\
\hline $\mathrm{Sb}$ & -- & 1800 & 100 & -- & 950 & 67 & -- & -- & 440 & -- & 710 & 130 & 430 \\
\hline Se & -- & - & - & -- & - & 1 & - & - & 130 & -- & 40 & 2.5 & 58 \\
\hline SI & 15000 & 420 & 1600 & 280 & 4300 & 120 & 3000 & 9200 & 5300 & 13000 & 8700 & 1900 & 5900 \\
\hline $\mathrm{Sr}$ & 7400 & 204 & 640 & 290 & 2100 & 55 & 640 & 250 & - & 1800 & 4200 & 550 & 1200 \\
\hline $\mathrm{Te}$ & 170 & 62 & 58 & 210 & 130 & 5.6 & 32 & 3.1 & 3.1 & 3.0 & 24 & 7.6 & 11 \\
\hline $\mathrm{Ti}$ & -- & -- & 1400 & 170 & 790 & 120 & 4100 & 8700 & 7200 & 5900 & 15000 & 1900 & 6100 \\
\hline $\mathrm{Zr}$ & -- & - & - & - & -- & - & - & 5000 & 13000 & 22000 & 9400 & 1900 & 10000 \\
\hline TOTAL $\pm \sigma$ & 1100 & 290 & 430 & $180 \pm 10$ & 500 & $120 \pm 50$ & 980 & $490 \pm 30$ & $480 \pm 90$ & $800 \pm 80$ & $1200 \pm 100$ & $1000 \pm 150$ & 720 \\
\hline
\end{tabular}

(a) Frlt-165 used for PSCM-6 through PSCM-8. Frit-131 used for all other tests.

(b) HIgh Al, low Fe feed employed. 
TABLE 12. Steady-State Aerosol Emission Characteristics

PSCM-5 Boosted Test

\begin{tabular}{|c|c|c|c|c|c|c|c|}
\hline \multirow[b]{2}{*}{ fapele } & \multirow{2}{*}{$\begin{array}{c}\text { Feed Rate, } \\
L / h\end{array}$} & \multicolumn{2}{|l|}{ Particulate } & \multirow[b]{2}{*}{$\begin{array}{l}\text { Sample } \\
\text { Type } \\
\text { Ty) }\end{array}$} & \multirow[b]{2}{*}{$\begin{array}{c}\text { Feed Rate, } \\
L / h\end{array}$} & \multicolumn{2}{|c|}{ Particulate } \\
\hline & & $\begin{array}{c}\text { Loading, (b) } \\
\mathrm{mg} / \mathrm{L}\end{array}$ & DF & & & $\begin{array}{c}\text { Loading, (b) } \\
\mathrm{mg} / \mathrm{L}\end{array}$ & DE \\
\hline C & 51 & 0.55 & 470 & S & 68 & 0.29 & 820 \\
\hline s & 72 & 0.49 & 460 & HEPA & 68 & -- & 810 \\
\hline$S$ & 79 & 0.44 & 510 & C & 67 & 0.37 & 840 \\
\hline c & 81 & 0.61 & 440 & $S$ & 74 & 0.25 & 910 \\
\hline HEPA & 81 & -- & 370 & c & 90 & 0.41 & 700 \\
\hline s & 86 & 0.48 & 492 & $S$ & 91 & 0.28 & 840 \\
\hline C & 93 & 0.78 & 440 & HEPA & 90 & -- & 720 \\
\hline HEPA & 93 & -- & 670 & $S$ & ${ }_{58}(c)$ & 0.32 & 870 \\
\hline ALL & & & 480 & C & $58^{(c)}$ & 0.54 & 660 \\
\hline & & & & ALL & & & 800 \\
\hline
\end{tabular}

PSCM-6 Boosted/Unboosted Test

(a) $C=$ cyclone; $S=$ differential samples; $H E P A=$ absolute filtration.

(b) STP.

(c) Unboosted operation.

A comparison of melter DFs achieved with alkaline and acidic waste slurries reveals that, with only a single exception, higher effective emission rates (lower DFs) were observed for the radiologically important semivolatiles when acidified melter waste was employed. The reducing power of the formic acid feed component apparently promotes volatilization in the plenum and thereby produces greater effective off-gas losses of these elements.

Ruthenium is an exception to the above statement. Ever since melter experiments with a formate feed formulation began, no significant airborne ruthenium has been detected in melter exhaust streams, except for the very atypical LFCM-7 test. Feed and glass sample analyses, on the other hand, indicate significant ruthenium melter losses ( $D F=2$ ), and yet no specific sink has been conclusively identified to account for these losses. In all probability, ruthenium is being reduced by the formic acid to its elemental state, whereupon it is lost to the melter floor as slag. A surface plateout mechanism is a possible, but less likely, explanation for these losses; however, no 
evidence of off-gas-line plating has ever been found. A thorough examination of the melter and its plenum revealed slag generation to be responsible for the observed ruthenium 1osses.

The effect of feed boosting upon melter emissions has been studied under controlled conditions. If the previous melter stability comments are neglected, Table 11 strongly suggests that melter DFs are dramatically reduced when boosting is employed. However, tests designed to illustrate this effect have failed to show any significant relationships between feeding rates and melter emissions. Table 12 presents gross aerosol DF values associated with the boosted PSCM-5 and PSCM-6 tests. Clearly, these data show no correlation between feeding rates and DFs. Moreover, the boosted PSCM-6 experiment did not utilize electric radiant lid heaters for the entire melter test, yet no significant differences in melter emissions were observed throughout the experiment. Consequently, this data suggests that electric radiant plenum heaters can be employed to boost liquid feeding rates of ceramic melters without significantly deteriorating melter performance.

The implementation of feed-boosting techniques, however, is not without operational difficulties. The high exhaust stream temperatures $\left(>600^{\circ} \mathrm{C}\right)$ resulting from the auxiliary plenum heaters can cause the formation of fused off-gas line deposits and accelerated material corrosion rates. A cooling spray (see Figure 2) has successfully controlled exiting melter exhaust gas temperatures to $400^{\circ} \mathrm{C}$ or less. However, the spray nozzle itself acts to collect entrained feed. These feed deposits ultimately grow to form a local obstruction to melter off-gas flow. Although these deposits are soft and easily removed, the current cooling spray configuration clearly compromises melter off-gas system design.

MELTER IDLING TEST

Because of the high $\left(\sim 1000^{\circ} \mathrm{C}\right)$ plenum temperatures associated with idling joule-heated ceramic melters, volatilization losses of radiologically important glass components during these periods could overwhelmingly influence the overall melter source term. The composition of typical melter idling emissions, 
which appears in Table 13, verifies the importance of this loss mechanism for the semivolatiles. In order to determine the overall importance of this melter loss mechanism, emission rates of semivolatile elements were investigated as a function of plenum temperature and, consequently, of the glass surface viscosity. Temperature control was maintained through use of plenum water sprays, which cooled but did not disturb the surface of the melter glass pool.

TABLE 13. Melter Idling Deposits

\begin{tabular}{|c|c|c|c|}
\hline \multirow[b]{2}{*}{ Oxides } & \multicolumn{3}{|c|}{ Weight Percent } \\
\hline & Gray Deposits & White Deposits & Glass \\
\hline $\mathrm{Al}_{2} \mathrm{O}_{3}$ & 1.2 & 0.11 & 3.7 \\
\hline $\mathrm{B}_{2} \mathrm{O}_{3}$ & 14.2 & 1.6 & 10.0 \\
\hline $\mathrm{CaO}$ & 0.22 & 0.46 & 1.2 \\
\hline $\mathrm{Cd} 0$ & 0.02 & 0.02 & 0.009 \\
\hline $\mathrm{Cr}_{2} \mathrm{O}_{3}$ & 0.57 & 0.58 & 0.02 \\
\hline $\mathrm{Cs}_{2} \mathrm{O}$ & 3.7 & 8.3 & 0.05 \\
\hline $\mathrm{Fe}_{2} \mathrm{O}_{3}$ & 0.10 & 0.17 & 14.8 \\
\hline $\mathrm{K}_{2} \mathrm{O}$ & 0.79 & 0.85 & $\star$ \\
\hline $\mathrm{Li}_{2}{ }^{0}$ & 1.92 & 2.6 & 4.4 \\
\hline MgO & 0.05 & 0.05 & 1.4 \\
\hline $\mathrm{MnO}_{2}$ & 0.05 & 0.05 & 3.9 \\
\hline $\mathrm{Na}_{2} \mathrm{O}$ & 31.0 & 31.0 & 15.7 \\
\hline $\mathrm{NiO}$ & 0.25 & 0.02 & 1.2 \\
\hline $\mathrm{RuO}_{2}$ & 0.82 & 2.1 & 0.01 \\
\hline $\mathrm{Sb}_{2} \mathrm{O}_{3}$ & 0.01 & 0.01 & 0.02 \\
\hline $\mathrm{SiO}_{2}$ & 0.02 & 0.47 & 45.1 \\
\hline sro & 0.005 & 0.005 & 0.02 \\
\hline $\mathrm{TeO}_{2}$ & 0.70 & 0.70 & 0.002 \\
\hline TiO & 0.01 & 0.01 & 0.8 \\
\hline $\mathrm{ZnO}$ & 0.02 & 0.02 & 0.008 \\
\hline
\end{tabular}

* Used in sample preparation. 
This study was initiated immediately after a 120-h liquid-fed melter test (PSCM-5). With a $42 \mathrm{~L} / \mathrm{h}$ water spraying rate and the melter under automatic resistance control, the melter glass surface was cooled to the point that it formed a continuous, nonconvective layer above the bulk melter glass pool (with plenum at $280^{\circ} \mathrm{C}$ ). At a $27 \mathrm{~L} / \mathrm{h}$ spray rate, the surface viscosity decreased significantly. Convective mixing opened vents in the glass surface that migrated at random across the melter glass pool. However, plenum temperatures were not high enough to melt feed deposits formed upon the melter walls and lid during the preceding PSCM-5 experiment. Finally, the cooling spray was terminated and the melter was allowed to idle at a fixed current rate, which slowly brought the melter plenum up to $850^{\circ} \mathrm{C}$. Samples were collected from the plenum during all phases of this study.

The results obtained from these plenum samples are yraphically summarized in Figure 8, which characterizes the emission rates of the semivolatile elements under various idling conditions (temperature) employed during this test. These data indicate that emission rates of all semivolatile elements decreased as a function of time after the completion of PSCM-5 at a $42 \mathrm{~L} / \mathrm{h}$ water-spraying rate. Reducing the cooling spray rate to $27 \mathrm{~L} / \mathrm{h}$ increased both plenum temperature and semivolatile emission rates; however, an equilibrated plenum temperature was not achieved during the brief $24-\mathrm{h}$ period of reduced spraying.

Termination of the water-cooling spray increased the plenum temperature steadily to the point where plenum surface deposits formed during PSCM-5 began to melt and "burn" away. The dramatic peaking of emission rates of the semivolatile elements occurred during this period. The fact that all semivolatiles do not form maxima at the same point in time is most probably due to temperature, which was steadily increasing throughout the interval over which these maxima occurred.

The plenum temperature during the last two sampling periods was $\sim 850^{\circ} \mathrm{C}$, and all plenum surfaces appeared clean. The emission rates during these periods are, with the exception of Se and Te, significantly greater than the minimum emission rates exhibited by these elements during full $42 \mathrm{~L} / \mathrm{h}$ spray cooling. However, these elevated idling emission rates are still significantly below those rates observed during moderate liquid feeding conditions. 


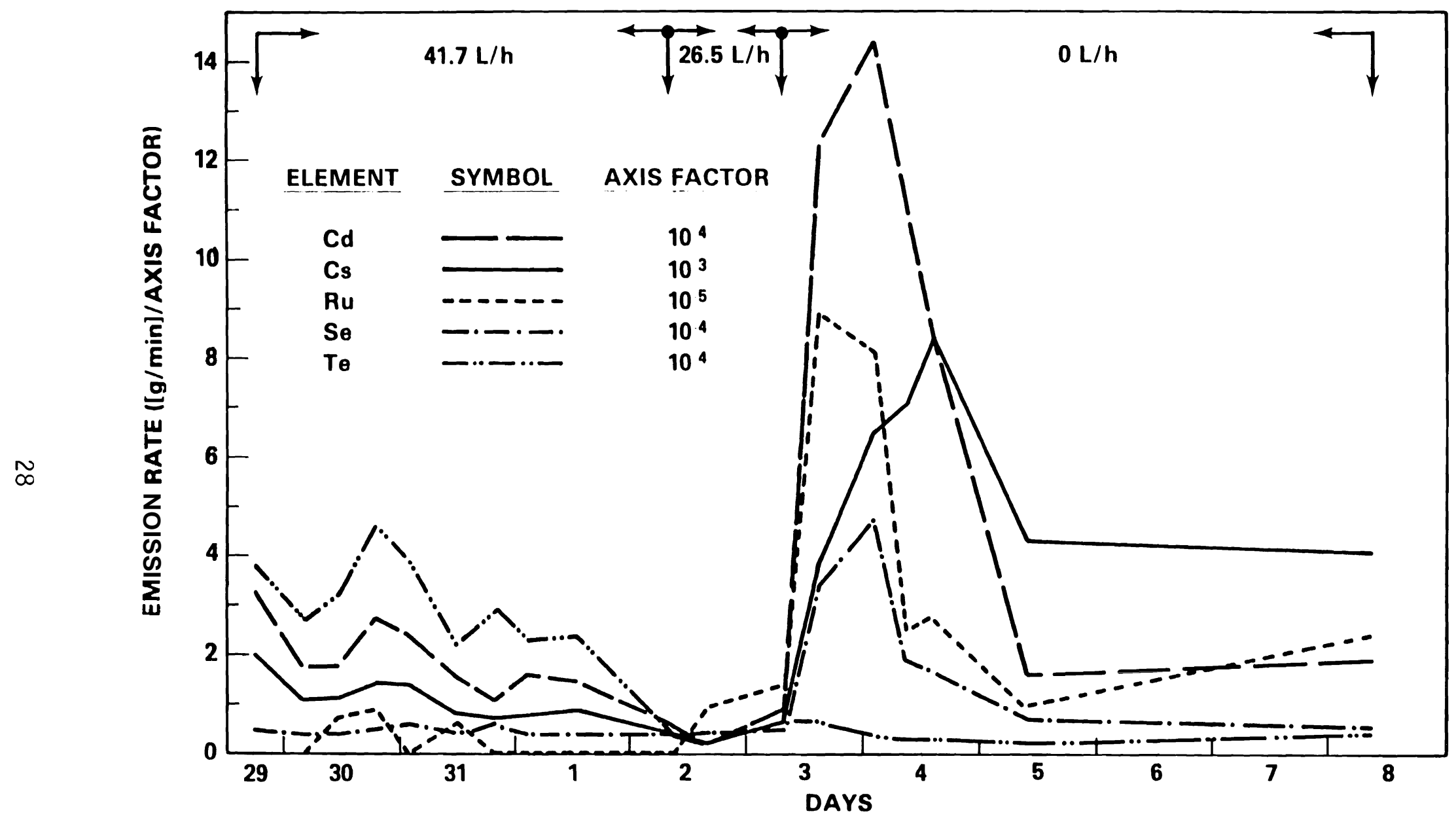

FIGURE 8. Melter Idling Emission Rates of Semivolatile Elements 
Specifically, the Cs emission rate expected from the PSCM for a liquid feeding rate of $50 \mathrm{~L} / \mathrm{h}(1.1 \mathrm{~kg} / \mathrm{min})$ would be about $10 \mathrm{mg} / \mathrm{min}$. This is more than twice the value observed during the hot melter idling conditions. Consequently, it appears that the plenum cooling approach, although capable of reducing emission rates of most semivolatiles (by a factor of 10 for Cs), is of little practical value in reducing the overall radiological burden of the melter off-gas system.

It should be noted that the effect of directly feeding water onto the surface of an idling melter has also been investigated as an alternative method for reducing idling emissions. This approach was, however, a less satisfactory means of cooling the plenum and melter glass surface than was the plenum spray approach. The water feeding technique produced a high degree of entrainment and aerosol carryover into the off-gas system. Moreover, at the water feeding rates used $(45 \mathrm{~L} / \mathrm{h})$, convective mixing was actually exacerbated, although total melter surface flooding was never attempted. On the other hand, the water plenum spray initiated no observed entrainment, and minimized or eliminated convective surface mixing.

\section{MELTER SLAG FORMATION}

After formic acid was added to the SRL reference feed composition, unaccountable losses of semivolatile spikes were observed. The most probable explanation for these feed component losses was melter production of insoluble metallic slag. Examination of the melter floor, after draining, confirmed that metallic slag formation had indeed occurred and was responsible for significant losses of $\mathrm{Ru}$, Se, and Te. The major metallic component of the harvested

nodules was, however, $\mathrm{Ni}$, which because of its $\mathrm{wt} \%$ in the feed is capable of producing significant slag accumulations on the melter floor. This in turn could seriously affect the service life of a production melter if slag generation or its accumulation is not controlled.

\section{MOLTEN SALT ACCUMULATION}

Due to the potential steam explosion hazards associated with the presence of molten salts within liquid-fed melters, the composition and accumulation 
rates of immiscible melter salt layers have been investigated. Time-dependent compositional behavior was assessed following PSCM-7. Salt samples extracted promptly after the PSCM-7 test were composed of alkali metal compounds of sulfate $(75 \mathrm{wt} \%)$ and chloride $(25 \mathrm{wt} \%)$. Samples extracted two days after termination of PSCM-7 were essentially all alkali sulfates. The presence of halogen salts in a molten sulfate phase during melter operation is somewhat disquieting since halogen salts have been shown to sensitize the water-molten $\mathrm{Na}_{2} \mathrm{SO}_{4}$ interactions. As a result, safety considerations may necessitate molten salt phase control.

A molten sulfate salt phase accumulates in a melter when the sulfate composition of the feed exceeds the capacity of the glass to incorporate it. The rate at which it accumulates will not only depend upon glass and feed characteristics, but will also depend upon melter off-gas loss rates of sulfur. Table 14 summarizes the behavior of sulfur for all formate feed tests for which adequate data exists. Although the sulfur distributional results are quite variable, a few general conclusions can be drawn: If the sulfur content of the feed is kept below $-0.025 \mathrm{wt} \%$, accumulations of $\mathrm{Na}_{2} \mathrm{SO}_{4}$ probably will not occur. On the other hand, if the glass capacity is exceeded by the sulfur in the feed, the excess will be distributed equally between a molten salt phase and the off-gas system.

TABLE 14. Relative Melter Production and Loss Rates of Sulfur

\begin{tabular}{|c|c|c|c|c|c|}
\hline \multirow[b]{2}{*}{ Melter Test } & \multicolumn{2}{|c|}{ Wt\% Sulfur } & \multicolumn{3}{|c|}{$\begin{array}{c}\text { Fractional Production/ } \\
\text { Loss Rates of Sulfur }\end{array}$} \\
\hline & Feed & GIass & Glass & $0 f f$ Gas & Molten Salt \\
\hline PSCM-3 & 0.05 & 0.09 & $>1$ & $>0.13$ & -- \\
\hline PSCM-4 & 0.081 & 0.044 & 0.54 & $>0.06$ & $<0.40$ \\
\hline PSCM-5 & 0.056 & 0.067 & $>1$ & 0.22 & -- \\
\hline PSCM-6 & 0.049 & 0.025 & 0.51 & 0.18 & 0.31 \\
\hline PSCM-7 & 0.070 & 0.035 & 0.50 & 0.34 & 0.16 \\
\hline PSCM-8 & 0.082 & $<0.02$ & $<0.24$ & 0.10 & $>0.66$ \\
\hline
\end{tabular}




\section{CLOSE-COUPLED SCRUBBER PERFORMANCE}

A close-coupled venturi ejector scrubber with cyclonic disengagement was added to the PSCM melter off-gas system prior to the PSCM-7 test. Since melter exhaust fouling of the off-gas system is most probable between the melter and the quencher, close coupling of a quench scrubber is an off-gas system necessity. Consequently, the performance characteristics of the close-coupled venturi ejector were carefully evaluated during PSCM-7 and PSCM- 8 , and the results obtained are summarized in Table 15. The variances in scrubber performance between these two tests can be ascribed to differences in off-gas particle size distributions and steam loadings produced by gross feed compositional differences. PSCM-8 generated larger aerosols on the average and possessed much higher off-gas water loadings (80\% versus 60\%) than did PSCM-7 (see Appendix for more details). The combined effect of these two factors can easily account for the observed differences in scrubber performance.

The overall system performance of the melter and scrubber combination was found to be quite invariant throughout the duration of each of the two tests. System upsets such as overfeeding during PSCM-8 or the use of a melter air sparge in PSCM-7 did not affect the overall system DF, although the melter and scrubber efficiencies were diametrically affected. This behavior is consistent with disturbances that would serve to increase gross entrainment losses.

\section{MELTER OFF-GAS ROW RATES}

The off-gas flow rates of the two liquid-fed melters have been examined over the past year as part of the SRL-DWPF melter development program. During this period of study, two separate feed formulations have been used, and a variety of melter operational running conditions have been employed. The results of these studies have shown that both feed composition and melter feeding rates have a preponderant influence upon the stability of melter offgas flow rate. 
TABLE 15. Close-Coupled Scrubber Particulate DFs

Scrubber DFs

\begin{tabular}{|c|c|c|}
\hline & & \\
\hline Element & PSCM-7 & PSCM-8 \\
\hline A1 & 81 & 5900 \\
\hline B & 5.2 & 6000 \\
\hline $\mathrm{Ba}$ & -- & -- \\
\hline $\mathrm{Ca}$ & 90 & 79 \\
\hline $\mathrm{Cd}$ & 19 & 14 \\
\hline C1 & -- & 37 \\
\hline $\mathrm{Cr}$ & 32 & 100 \\
\hline Cs & 18 & 11 \\
\hline $\mathrm{Cu}$ & 20 & 260 \\
\hline$F$ & 11 & -- \\
\hline $\mathrm{Fe}$ & 260 & 3600 \\
\hline La & 52 & 800 \\
\hline Li & 23 & 63 \\
\hline $\mathrm{Mg}$ & -- & 220 \\
\hline Mn & 470 & 1500 \\
\hline $\mathrm{Na}$ & 20 & 33 \\
\hline $\mathrm{Nd}$ & 140 & -- \\
\hline $\mathrm{Ni}$ & 120 & 150 \\
\hline $\mathrm{Pb}$ & 12 & 13 \\
\hline S & 7.7 & 75 \\
\hline $\mathrm{Sb}$ & 23 & 36 \\
\hline Se & 7.9 & 3 \\
\hline Sì & 180 & 10000 \\
\hline $\mathrm{Sr}$ & 9.1 & 360 \\
\hline Te & 14 & 13 \\
\hline $\mathrm{Ti}$ & 13 & -- \\
\hline $\mathrm{Zn}$ & 23 & 900 \\
\hline $\mathrm{Zr}$ & 36 & - \\
\hline TOTAL & 9 & 54 \\
\hline
\end{tabular}


The effect of feed composition upon melter flow rate behavior is related to the physical ability of the feed components to form a structurally sound insulatiny layer (cold cap) between the incoming liquid feed and the hot glass surface. As portions of the insulating cold cap become calcined, structural collapse occurs, bringing dammed-up liquid feed into contact with the extremely hot glass surface. This results in the flashing off of the water component (and volatile reaction products) of the feed, producing a flow pulse or an offgas surge. The magnitude and extent of these surges are naturally dependent upon the amount of liquid feed present on the cold cap that is delivered to the hot glass surface. Consequently, an erratic flow rate from the melter exhaust is often indicative of an unstable, overfed operational condition. Exhaust flow rate patterns associated with stable and unstable melter operation are illustrated in Figure 9.

The two melter feed formulations used in these studies exhibited significantly different melter off-gas properties. The alkaline waste formulation produced a noisy, erratic melter flow rate with surges as high as seven times that of the average flow. The acid feed, on the other hand, possessed a very compliant, nonbridging cold cap, which reduced the frequency and magnitude of off-gas surging events. Average melter flow characteristics associated with each of these feed formulations are summarized in Table 16. These data clearly show the stabilizing influence of the formic acid feed component upon melter flow rate behavior.

Due to the conservative, stable manner in which most PSCM runs were conducted, PSCM flow rate data associated with acidified feed are probably more representative of average melter behavior than are the values associated with the LFCM. The LFCM data, on the other hand, can be used in assessing the effects of heavy melter feeding conditions upon melter off-gas flow rate.

\section{CORROSION}

Extensive metal corrosion has been observed in liquid-fed melter plenums and in associated melter off-gas lines and processing equipment. The nature of the corrosion observed suygests acidic chemical attack by volatile halogens and 


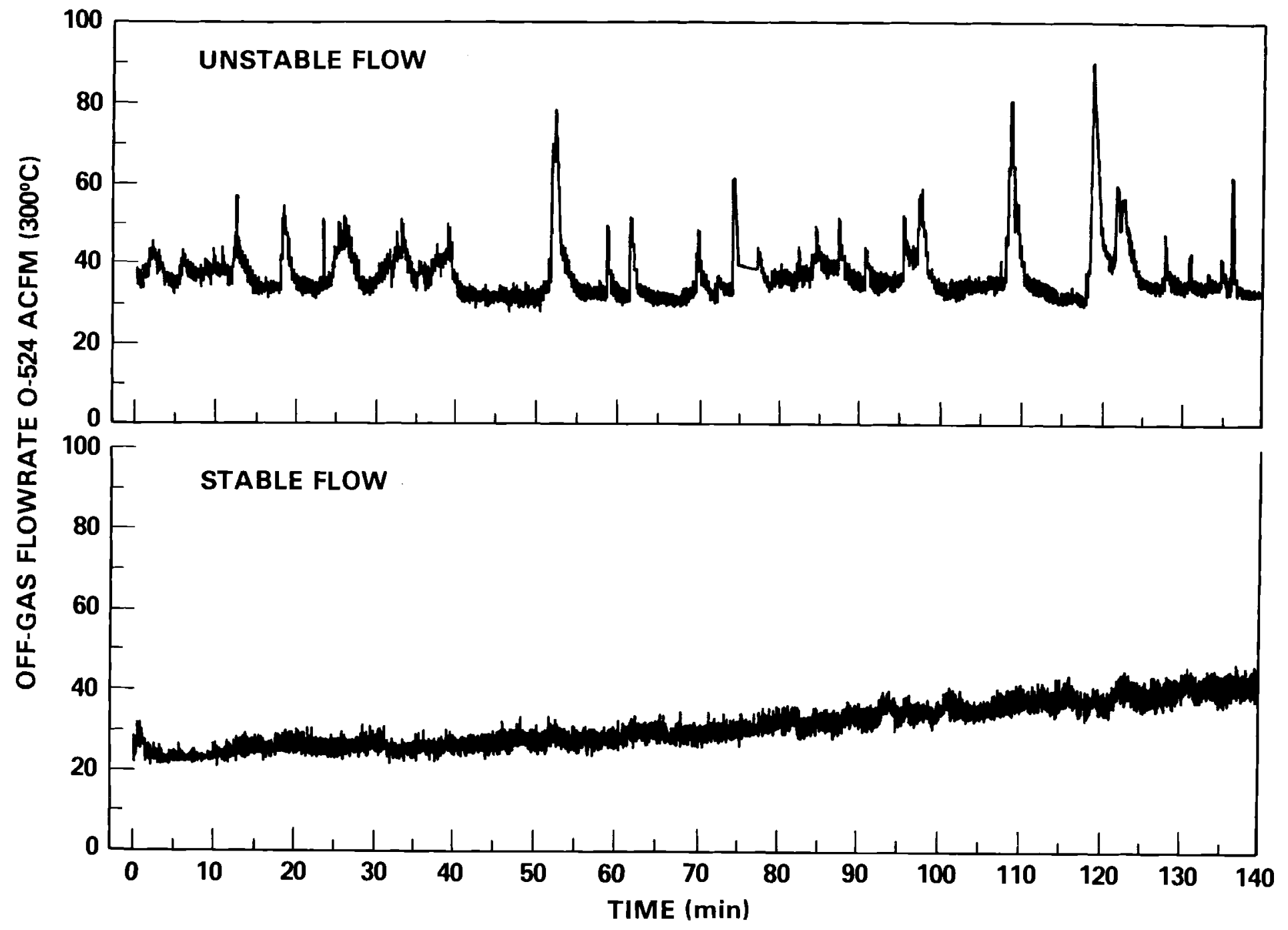

FIGURE 9. Typical Off-Gas Flow Rate Behavioral Patterns Associated with Liquid-Fed Melters 
TABLE 16. Liquid-Fed Melter Flow Rates

\begin{tabular}{|c|c|c|c|c|}
\hline Experiment & Feed & $\begin{array}{l}\text { Average, } \\
\text { Flow, scfm }\end{array}$ & $\begin{array}{c}\text { Maximum } \\
\text { Surge, scfm }\end{array}$ & $\begin{array}{l}\text { Average Surge } \\
\text { Duration, min }\end{array}$ \\
\hline LFCM-4 & Alkaline & 90 & 620 & 3 \\
\hline LFCM-6 & Alkaline & 90 & 470 & 3 \\
\hline PSCM-3 & Acid & 70 & 220 & 3 \\
\hline LFCM-7 & Acid & 240 & 710 & 3 \\
\hline PSCM-4 & Acid & 70 & 300 & 4 \\
\hline PSCM-5 & Acid & 80 & 230 & 3 \\
\hline PSCM-6 & Acid & 80 & 190 & 3 \\
\hline
\end{tabular}

sulfur compounds. In order to identify suitably corrosive-resistant materials for the melter off-gas treatment system, corrosion coupons representing different groups of alloys were exposed to the plenum environment of liquid-fed melters during processing $\left(300\right.$ to $\left.500^{\circ} \mathrm{C}\right)$ and idling $\left(850^{\circ} \mathrm{C}\right)$ conditions. The extent of corrosion as a function of operating conditions was established gravimetrically through coupon weight loss. The results of these studies, which are summarized in Table 17, indicate that the corrosion rates occurring during actual liquid feeding are much greater than those occurring during hot idling, although temperature cycling between feeding and idling accelerates overall corrosion rates. In addition, titanium, tantalum and all alloys having high iron concentrations were unsuitable for liquid-fed melter service. The most promising alloys are those possessing a content low in iron and high in nickel or cobalt, and a chromium content greater than $20 \%$. Inconel-625 and the Haynes alloys were the most corrosive-resistant materials employed during this study.

\section{$\underline{\text { CONCLUSIONS }}$}

The off-gas studies discussed in this report have sought to establish the effluent characteristics of liquid-fed joule-heated ceramic melters. The results of these studies have shown particulate emission to be responsible for most melter effluent losses. Moreover, a large fraction of the total particulate mass evolved from an operating melter is conveyed to the off-gas system by 
TABLE 17. Corrosion Sample Results

\begin{tabular}{|c|c|c|c|c|c|c|c|c|c|c|c|c|c|}
\hline \multirow[b]{2}{*}{ Material } & \multicolumn{2}{|c|}{ Exposure, $h$} & \multirow{2}{*}{$\begin{array}{l}\text { Wei ght } \\
\text { Chanye } \\
y / \text { cni2 }\end{array}$} & \multirow{2}{*}{$\begin{array}{l}\text { Cor. } \\
\text { Rate } \\
\text { cm/yr } \\
\end{array}$} & \multicolumn{3}{|c|}{ Observations } & \multicolumn{2}{|c|}{ Approximat } & \multicolumn{4}{|c|}{ Composition, wt\% } \\
\hline & Idling & Operating & & & Spalling & Deposits $(a)$ & Color $(b)$ & $\mathrm{Cr}$ & Co & $\mathrm{Fe}$ & $\mathrm{Ni}$ & Mo & $W$ \\
\hline Incone $10-690$ & $\begin{array}{r}1134 \\
198 \\
1256 \\
320\end{array}$ & $\begin{array}{l}214 \\
214 \\
214 \\
330\end{array}$ & $\begin{array}{l}-0.025 \\
-0.014 \\
-0.036 \\
-0.011\end{array}$ & $\begin{array}{l}0.020 \\
0.074 \\
0.023 \\
0.015\end{array}$ & $\begin{array}{l}\text { Light } \\
\text { Light } \\
\text { Light } \\
\text { Light }\end{array}$ & $\begin{array}{l}\text { Light } \\
\text { None } \\
\text { Light } \\
\text { Light }\end{array}$ & $\begin{array}{l}\text { Blk-Silver } \\
\text { Black } \\
\text { Multi } \\
\text { Black }\end{array}$ & 30 & -- & 9.5 & 60 & -- & - \\
\hline Incone $10-625$ & $\begin{array}{r}1134 \\
198 \\
1256 \\
320\end{array}$ & $\begin{array}{l}214 \\
214 \\
330 \\
330\end{array}$ & $\begin{array}{l}+0.015 \\
+0.007 \\
+0.013 \\
+0.012\end{array}$ & & $\begin{array}{l}\text { None } \\
\text { None } \\
\text { None } \\
\text { None }\end{array}$ & $\begin{array}{l}\text { Heavy } \\
\text { Heavy } \\
\text { Heavy } \\
\text { Heavy }\end{array}$ & $\begin{array}{l}\text { Brown } \\
\text { Brn-Silver } \\
\text { Brn-Black } \\
\text { Brn-Silver }\end{array}$ & 21.5 & -- & 2.5 & 61 & 9 & -- \\
\hline Inconel ${ }_{-617}$ & $\begin{array}{l}122 \\
122\end{array}$ & $\begin{array}{l}116 \\
116 \\
\end{array}$ & $\begin{array}{l}-0.004 \\
-0.013 \\
\end{array}$ & $\begin{array}{l}0.008 \\
0.024 \\
\end{array}$ & $\begin{array}{l}\text { Med-Pits } \\
\text { Med-Pits }\end{array}$ & $\begin{array}{l}\text { Medi ium } \\
\text { Medi um }\end{array}$ & $\begin{array}{l}\text { Gr-Silver } \\
\text { Gr-Silver }\end{array}$ & 22 & 12.5 & 1.5 & 52 & 9 & -- \\
\hline Incone $l^{\star}-600$ & $\begin{array}{l}122 \\
122\end{array}$ & $\begin{array}{l}116 \\
116\end{array}$ & $\begin{array}{l}-0.008 \\
-0.002\end{array}$ & $\begin{array}{l}0.015 \\
0.004\end{array}$ & $\begin{array}{l}\text { Medi um } \\
\text { Medi um }\end{array}$ & $\begin{array}{l}\text { Light } \\
\text { Light }\end{array}$ & $\begin{array}{l}\text { Multi } \\
\text { Multi }\end{array}$ & 15.5 & -- & 8 & 76 & -- & -- \\
\hline Haynes ${ }^{\bullet} 188$ & $\begin{array}{r}1134 \\
198\end{array}$ & $\begin{array}{l}214 \\
214\end{array}$ & $\begin{array}{l}+0.059 \\
+0.004\end{array}$ & & Light & $\begin{array}{l}\text { Very Light } \\
\text { Light }\end{array}$ & $\begin{array}{l}\text { Bl-Black } \\
\text { Bl-Black }\end{array}$ & 22 & 40 & 3 & 10 & -- & 15 \\
\hline Haynes $-2 b$ & $\begin{array}{r}1134 \\
198 \\
60 \\
\end{array}$ & $\begin{array}{l}214 \\
214 \\
110 \\
\end{array}$ & $\begin{array}{l}+0.005 \\
+0.003 \\
+0.001 \\
\end{array}$ & 0.008 & $\begin{array}{l}\text { Light } \\
\text { Light } \\
\text { None }\end{array}$ & $\begin{array}{l}\text { Light } \\
\text { Light } \\
\text { None }\end{array}$ & $\begin{array}{l}\text { Bl-Black } \\
\text { Bl-Black } \\
\text { Black }\end{array}$ & 21 & 54 & 3 & 10 & -- & 15 \\
\hline$K A^{\oplus}-330$ & $\begin{array}{r}1134 \\
198\end{array}$ & $\begin{array}{l}214 \\
214\end{array}$ & $\begin{array}{l}-0.025 \\
-0.036\end{array}$ & $\begin{array}{l}0.020 \\
0.185\end{array}$ & $\begin{array}{l}\text { Medium } \\
\text { Medium }\end{array}$ & $\begin{array}{l}\text { None } \\
\text { None }\end{array}$ & $\begin{array}{l}\text { Multi } \\
\text { Gir Spots }\end{array}$ & 18 & $-\infty$ & 47 & 35 & -- & -- \\
\hline$R A^{\oplus-446}$ & $\begin{array}{r}1134 \\
198\end{array}$ & $\begin{array}{l}214 \\
214\end{array}$ & $\begin{array}{l}-0.18 \\
-0.17\end{array}$ & $\begin{array}{l}0.145 \\
0.472\end{array}$ & $\begin{array}{l}\text { Heavy } \\
\text { Heavy }\end{array}$ & $\begin{array}{l}\text { None } \\
\text { None }\end{array}$ & $\begin{array}{l}\text { Multi } \\
\text { Multi }\end{array}$ & 25 & -- & 75 & -- & -- & -- \\
\hline $\begin{array}{l}\text { Titaniuin } \\
\text { Tantalum }\end{array}$ & $\begin{array}{l}122 \\
122\end{array}$ & $\begin{array}{l}116 \\
116\end{array}$ & $\begin{array}{l}-0.063 \\
-3.3\end{array}$ & $\begin{array}{l}0.210 \\
>3\end{array}$ & $\begin{array}{l}\text { Heavy } \\
\text { Disappeared }\end{array}$ & None & Silver-Brn & -- & -- & -- & -- & -- & -- \\
\hline
\end{tabular}

(a) Feed naterial sintered on coupon surface.

(b) Bl - Blue; Blk - Black; Brn - Brown; Gr - Green.

- Inconel is a registered trademark of Hunt ington Alloys, Huntington, West Viryinia.

- Haynes is a registered trademark of the Cabot Corporation, Kokomo, Indiana.

- RA is a registered trademark of Rolled Alloys, Detroit, Michigan. 
submicron aerosols which are almost exclusively responsible for semivolatile transport. Melter operational conditions have had little effect upon these results as long as quasi-steady-state conditions are maintained. Even hot melter idling conditions do not significantly affect the overall melter source term.

Melter-generated gases have been found to be potentially flammable as well as corrosive. Hydrogen generation presents the greatest flammability hazard of the combustibles generated by liquid-fed melters. Off-gas dilution was required during a melter test to maintain the $\mathrm{H}_{2}$ concentration below $70 \%$ of its lower flammability limit in the quenched melter exhaust. The combustible gas CO has never achieved a quenched off-gas concentration greater than $1 / 10$ of its flammability limit. Auxiliary plenum heating significantly reduces melter emission rates of both these combustible gases.

Significant concentrations of acidic volatile compounds of sulfur and the halogens exist in unquenched melter off-gas streams independent of melter operation. These gases have been responsible for extensive corrosion observed in melter plenums and in associated off-gas lines and processing equipment. Alloys possessing low iron, high nickel or cobalt, and high chromium content are the most suitable for liquid-fed melter service. 


\section{REFERENCES}

Bjorklund, W. J. 1982. Defense Waste Vitrification Studies During FY-1981. PNL-4366, Pacific Northwest Laboratory, Richland, Washington.

Bonner, W. F. 1979. The High-Level Waste Immobilization Program: An Overview. PNL-3094, Pacific Northwest Laboratory, Richland, Washington.

Buelt, J.L., and C. C. Chapman. 1978. Liquid-Fed Ceramic Melter: A General Description Report. PNL-2735, Pacific Northwest Laboratory, Richland, Washington.

Conroy, A. R., W. H. Manning, and W. C. Bauer. 1966. "The Role of Sulfate in the Melting and Fining of Glass Batch." Glass Ind 47(2):84-89.

Ethridge, L. J. 1983. Defense Waste Vitrification Studies During FY 1982.

PNL-4834, Pacific Northwest Laboratory, Richland, Washington. 


\section{APPENDIX}

OFF-GAS DATA COMPILATION FOR LIQUID FEEDING OF CERAMIC MELTERS 

APPENDIX

OFF-GAS DATA COMPILATION

FOR LIQUID FEEDING OF CERAMIC MELTERS

INTRODUCTION

Off-gas and effluent characterization studies have been estabished as part of the SRL-DWPF melter development program being conducted at PNL. The objective of these studies is to establish the off-gas properties of liquid-fed joule-heated melters as a function of melter operational parameters. The scope of these studies is quite broad and covers all aspects of off-gas concern including

- effluent characterization

- flow rate behavior

- corrosion effects

- emission abatement.

The purpose of this appendix is to present all off-gas data compiled since liquid-fed melter tests began in support of DWPF. During this period, 13 major melter experiments have been conducted. These are listed below according to abbreviation and date:

\begin{tabular}{clll} 
Experiment $(\mathrm{a})$ & & \multicolumn{2}{c}{ Date } \\
\cline { 4 - 5 } LFCM-2 & & September & 1980 \\
LFCM-3 & & November & 1980 \\
PSCM-1 & & December & 1980 \\
LFCM-4 & & January & 1981 \\
PSCM-2 & & March & 1981 \\
LFCM-6 & & June & 1981 \\
PSCM-3 & & July & 1981 \\
LFCM-7 & & August & 1981 \\
PSCM-4 & & December & 1981 \\
PSCM-5 & & January & 1981 \\
PSCM-6 & & March & 1982 \\
PSCM-7 & & May & 1982 \\
PSCM-8 & & June & 1982
\end{tabular}

(a) LFCM and PSCM refer to the Liquid Fed Ceramic Melter and Pilot-scāale Cerámic Melter, respectively. 
The details concerning these experiments are fully described and documented in melter test summary documents (Bjorklund 1982; Ethridge 1983). As an aid in reading this report, all pertinent melter operational parameters associated with each experiment to be discussed are listed in Table A.1.

Both melters being studied in this report share a common 0.1-m (4-in.) stainless steel off-gas system consisting of an ejector venturi, a downdraft condenser, and a packed scrubbing tower. The arrangement of these components is illustrated in Figure A.1. In addition to these common of $f$-gas elements, both melters are equipped with a close-coupled HEPA filter receptacle and a total (condensible and noncondensible) of f-gas flowmeter. However, since the PSCM off-gas HEPA filtration capability was added during lid modifications of this melter, total off-gas filtration data were not available for the PSCM-3 experiment.

An additional venturi ejector was added to the PSCM off-gas system during May 1982. The wet scrubber was close coupled to the PSCM melter by a $2-m$ length of $15-\mathrm{cm}\left(6-\mathrm{in}_{0}\right)$ pipe. The performance of this scrubber was evaluated during the last two tests (PSCM-7 and -8) covered in this appendix.

\section{EFFLUENT CHARACTERIZATION}

\section{LFCM-2 - SEPTEMBER 1980}

Briefly, LFCM-2 was a 120 -h test to demonstrate a steady-state glass production of $40 \mathrm{~kg} / \mathrm{h}-\mathrm{m}^{2}$ using lid boosting (see Table A.1 for more details). During this run, a $5.9-\mathrm{kg}$ (13-1b) plug formed in a horizontal section of offgas-line $\sim 3 \mathrm{~m}(10 \mathrm{ft})$ from the melter lid. The off-gas temperature at this location ranged between 400 and $600^{\circ} \mathrm{C}$ throughout the duration of plug formation. Figure A.2 schematically illustrates the components of the LFCM off-gas line that were later disassembled for inspection. Figures A.3 through A.5 are photographs of the piping sections called out in Figure A.2. The composition of the plug materials is compared with that of the feed in Table A.2, where an oxide composition has been assumed except for the anions. With the exception of the anions, the three most highly enriched elements in the plug relative to 
TABLE A.1. Liquid-Fed Melter Operational Parameters

\begin{tabular}{|c|c|c|c|c|c|c|c|c|c|c|c|c|c|}
\hline \multirow{2}{*}{$\begin{array}{l}\text { Operational } \\
\text { Parameters } \\
\end{array}$} & \multicolumn{13}{|c|}{ Equi i pment } \\
\hline & LFCM-2 & LFCM-3 & LFCM-4 & PSCM-1 & $\mathrm{PSCM}-2$ & LFCM-4 & $\mathrm{PSCM}-3$ & LFCM-7 & $\mathrm{PSCM}-4$ & PSCM-5 & PSCM-6 & PSCM-7 & PSCM-8 \\
\hline $\begin{array}{l}\text { Feed Rate, } \\
\mathrm{kg} / \mathrm{h}-\mathrm{m}^{2}\end{array}$ & 80 & 50 & 90 & 45 & 110 & 100 & 62 & 130 & 120 & 135 & 165 & 95 & 140 \\
\hline $\begin{array}{l}\text { Glass Pro- } \\
\text { duction, } \\
\text { Rate, } \\
\mathrm{kg} / \mathrm{h}-\mathrm{m}^{2}\end{array}$ & 37 & 21 & 41 & 22 & 50 & 45 & 28 & 57 & 39 & 46 & 65 & 41 & 49 \\
\hline $\begin{array}{l}\text { Boosting } \\
\text { type }\end{array}$ & $\begin{array}{l}\text { Elect. } \\
\text { Lid } \\
\text { Heat }\end{array}$ & None & $\begin{array}{l}\text { Elect. } \\
\text { Lid } \\
\text { Heat }\end{array}$ & None & $\begin{array}{l}\text { Propane } \\
\text { Combus- } \\
\text { tion }\end{array}$ & $\begin{array}{l}\text { Elect. } \\
\text { Lid and } \\
\text { Plasma } \\
\text { Torch }\end{array}$ & None & $\begin{array}{l}\text { Elect. } \\
\text { Lid } \\
\text { Heat }\end{array}$ & None & $\begin{array}{l}\text { Elect. } \\
\text { Lid } \\
\text { Heat }\end{array}$ & $\begin{array}{l}\text { Elect. } \\
\text { Lid } \\
\text { Heat }\end{array}$ & None & $\begin{array}{l}\text { Elect. } \\
\text { Lid } \\
\text { Heat }\end{array}$ \\
\hline $\begin{array}{l}\text { Boosting } \\
\text { Power, kw }\end{array}$ & $\sim 25$ & -- & 30 & -- & 35 & 40 & -- & 15 & -- & 36 & 55 & -- & 45 \\
\hline $\begin{array}{l}\text { Off-Gas } \\
\text { Temp.., }{ }^{\circ} \mathrm{C}\end{array}$ & $300-600$ & 325 & 375 & 375 & 375 & 350 & 210 & 250 & 275 & 375 & 400 & 280 & 360 \\
\hline $\begin{array}{l}\text { off-Gas } \\
\text { Cooling, } \\
\text { gph }\end{array}$ & None & None & 2 & None & 6 & 5 & None & Varlable & None & 6 & 6 & None & 8 \\
\hline $\begin{array}{l}\text { Experiment } \\
\text { Duration, } \\
\text { hours }\end{array}$ & 120 & 24 & 120 & 120 & 120 & 120 & 135 & 120 & 107 & 99 & 138 & 115 & 232 \\
\hline
\end{tabular}




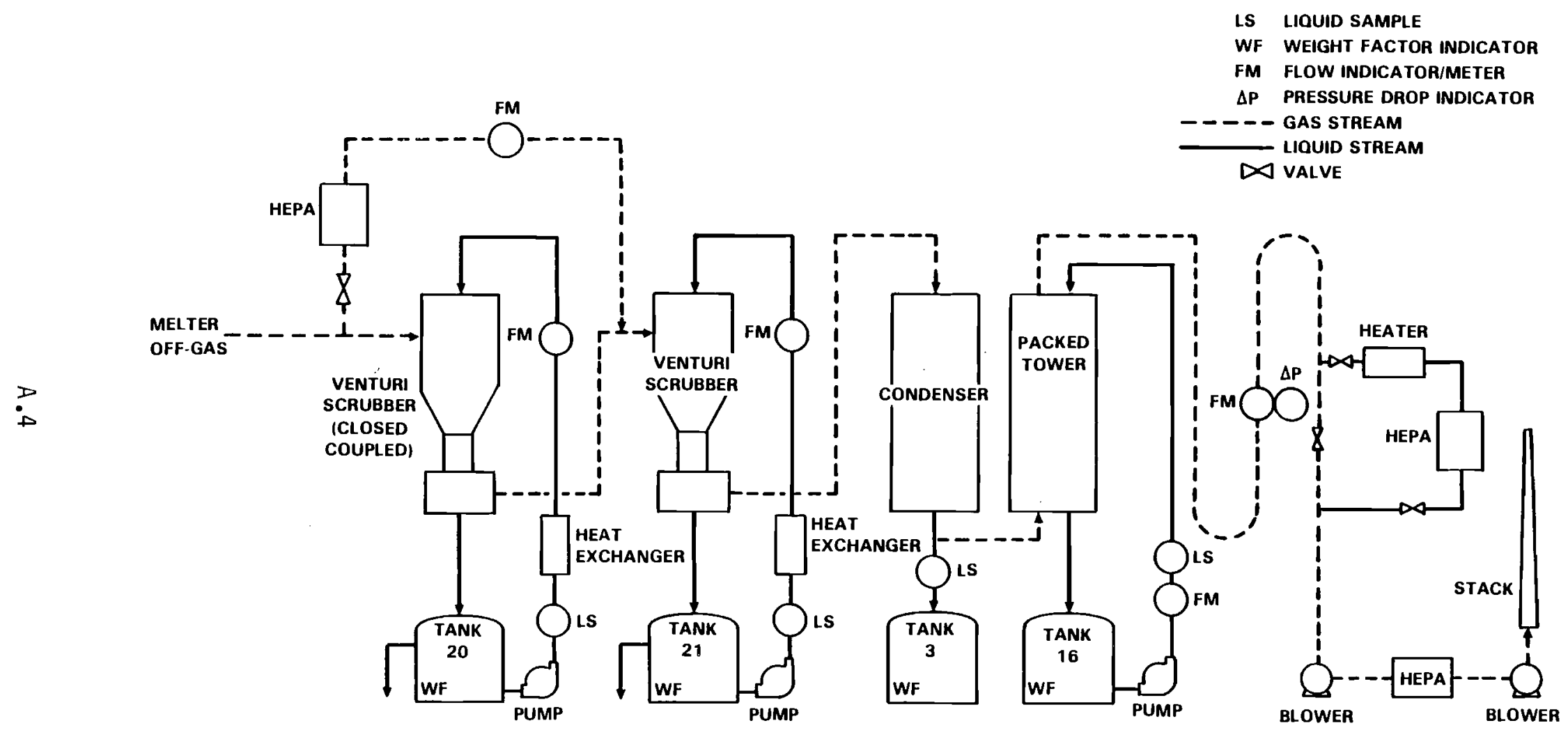

FIGURE A.1. Off-Gas Treatment System 


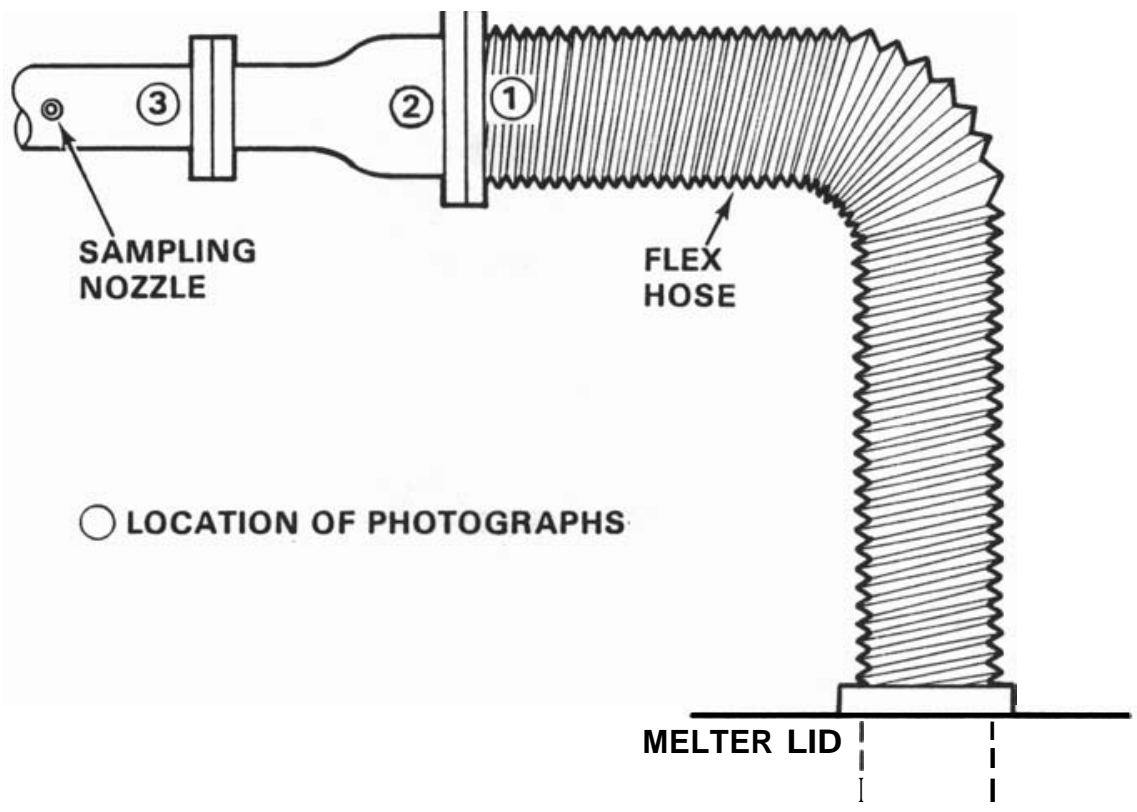

FIGURE A2. LFCM-2 Off-Gas Line

Schematic

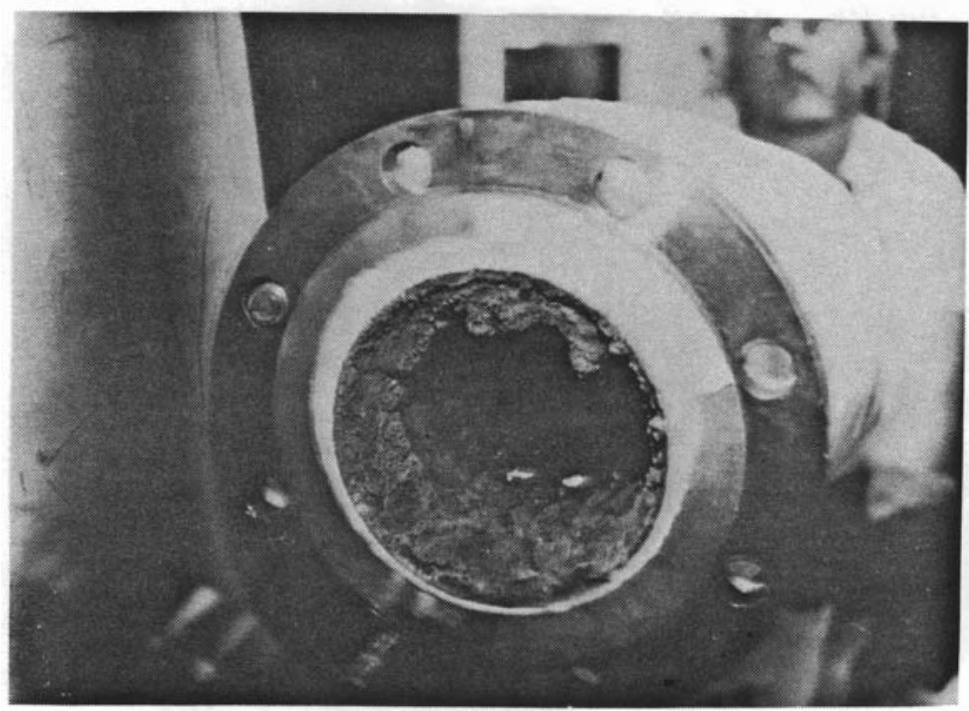

FIGURE A.3. LFCM-2 \#1 


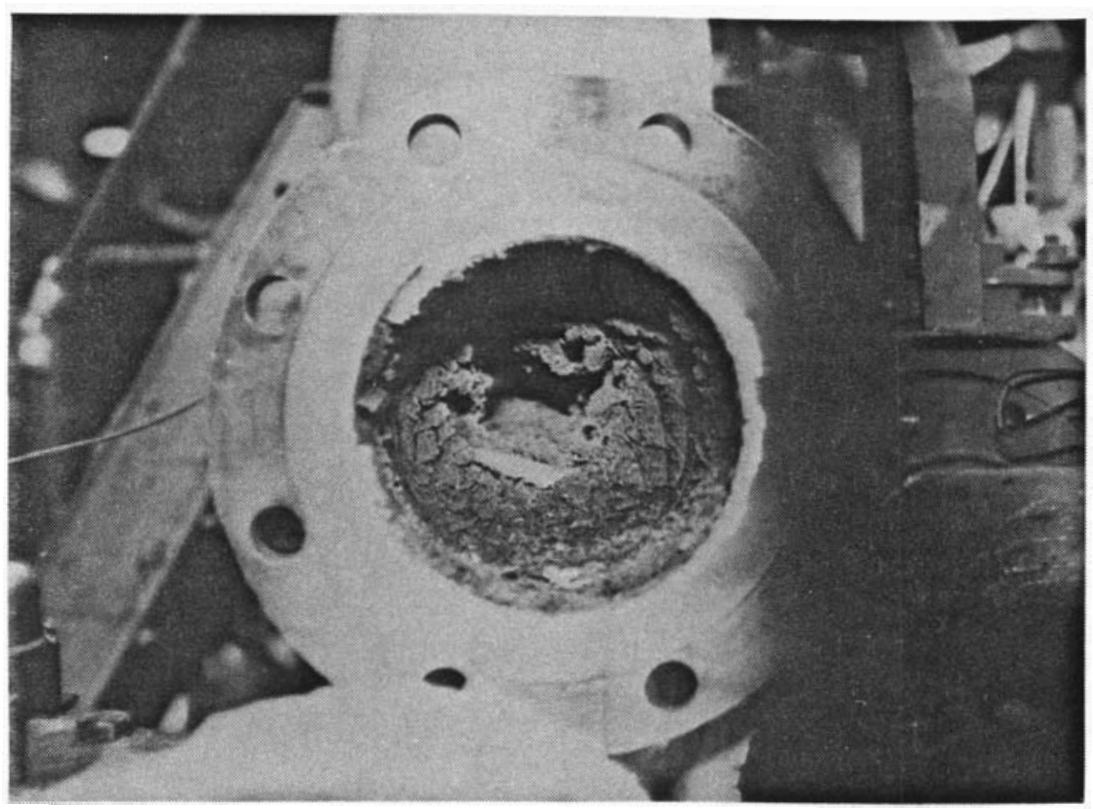

FIGURE A.4. $\quad$ LFCM-2 \#2

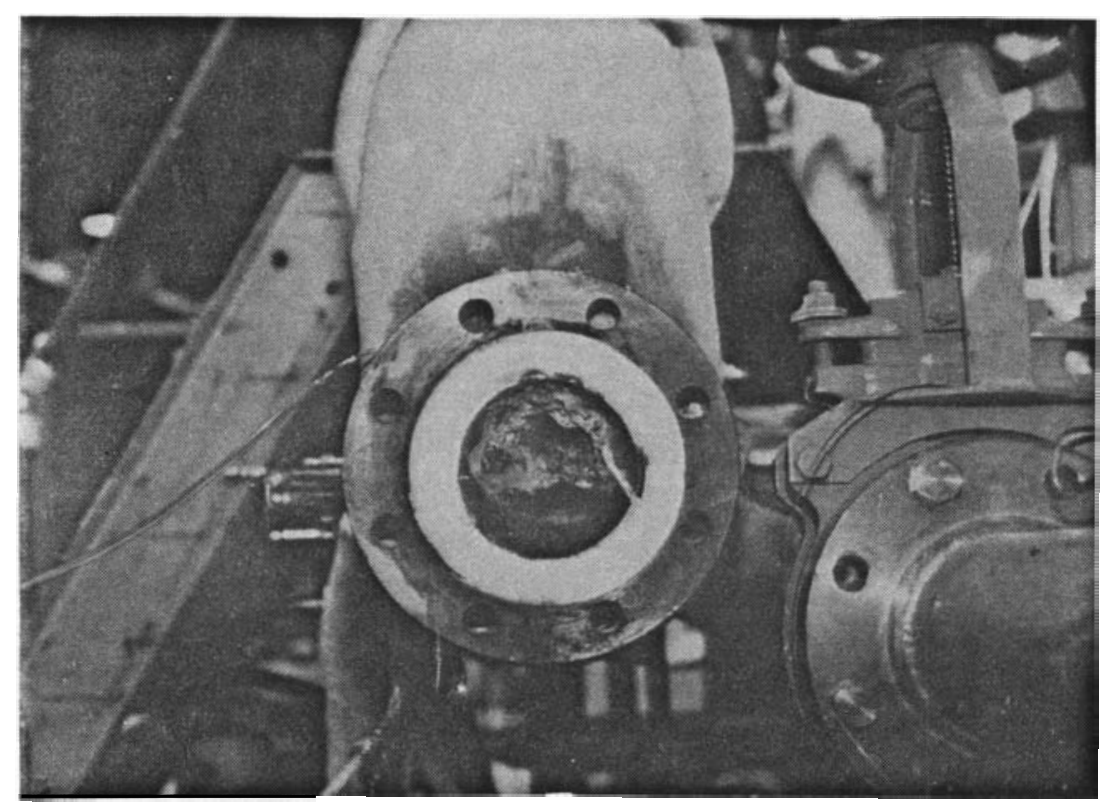

FIGURE A.5. LFCM-2 \#3 


\section{TABLE A.2. LFCM-2 Plug Composition}

\begin{tabular}{|c|c|c|c|}
\hline $\begin{array}{l}\text { Elemental } \\
\text { Oxides } \\
\end{array}$ & $\begin{array}{c}\text { Average wt } \% \\
\text { in Plug } \\
\end{array}$ & $\begin{array}{l}\text { Wt } \% \text { Feed } \\
9 / 18 / 82 \\
2030 \mathrm{~h} \\
\end{array}$ & $\begin{array}{l}\text { Wt\% Ratio } \\
\text { Plug/Feed }\end{array}$ \\
\hline $\mathrm{Al}_{2} \mathrm{O}_{3}$ & 1.67 & 2.96 & 0.56 \\
\hline $\mathrm{B}_{2} \mathrm{O}_{3}$ & 4.62 & 3.78 & 1.22 \\
\hline $\mathrm{CaO}$ & 4.40 & 4.62 & 0.95 \\
\hline $\mathrm{Cl}^{-}$ & 10.00 & -- & -- \\
\hline $\mathrm{Cr}_{2} \mathrm{O}_{3}$ & 0.42 & -- & -- \\
\hline $\mathrm{Cs}_{2} \mathrm{O}$ & 0.26 & 0.04 & 6.5 \\
\hline $\mathrm{F}^{-}$ & 0.24 & -- & -- \\
\hline $\mathrm{Fe}_{2} \mathrm{O}_{3}$ & 20.3 & 10.9 & 1.86 \\
\hline $\mathrm{Li}_{2} \mathrm{O}$ & 2.02 & 2.42 & 0.83 \\
\hline $\mathrm{MgO}$ & 0.22 & 0.11 & 2.00 \\
\hline $\mathrm{MnO}_{2}$ & 1.21 & 3.67 & 0.32 \\
\hline $\mathrm{Na}_{2} \mathrm{O}$ & 16.9 & 13.0 & 1.30 \\
\hline $\mathrm{NiO}$ & 2.49 & 1.32 & 1.89 \\
\hline $\mathrm{RuO}_{2}$ & 0.30 & 0.01 & 30.0 \\
\hline $\mathrm{SiO}_{2}$ & 31.0 & 35.0 & 0.89 \\
\hline $\mathrm{SO}_{4} \stackrel{=}{=}$ & 1.9 & 0.003 & 0.630 \\
\hline SrO & 0.04 & 0.02 & 2.0 \\
\hline $\mathrm{Te}_{2}$ & 0.07 & 0.004 & 17.5 \\
\hline $\mathrm{TiO}_{2}$ & 0.07 & 0.03 & 2.33 \\
\hline Zno & 0.08 & 0.04 & 2.0 \\
\hline
\end{tabular}

the feed are Ru, Te and Cs. Significant quantities of stainless steel corrosion products, including $\mathrm{Ni}$ and $\mathrm{Cr}$, were also present as part of the plug material.

Total decontamination factors (DFs) associated with melter feed components were calculated from analytical results obtained from the condensible off-gas sampliny train and the composition and weight of all process-1ine deposits. These results appear in Table A.3. The DFs obtained for sulfates, nitrates, and fluorides are upper limits since total analysis for these anions was not possible. 


\section{TABLE A.3. LFCM-2 Decontamination Factors}

\begin{tabular}{|c|c|c|c|}
\hline Element & Minimum & Maximum & Average DF \\
\hline Al & 3750 & 7700 & 4900 \\
\hline B & 180 & 530 & 260 \\
\hline $\mathrm{Ca}$ & 540 & 950 & 740 \\
\hline $\mathrm{Cd}^{(\mathrm{a})}$ & 120 & 560 & 340 \\
\hline $\mathrm{Cl}$ & 9 & 32 & 17 \\
\hline Cs & 30 & 70 & 40 \\
\hline$F(b)$ & -- & -- & $>175$ \\
\hline $\mathrm{Fe}$ & 330 & 950 & 420 \\
\hline Li & 690 & 1120 & 920 \\
\hline $\mathrm{Mg}$ & 340 & 640 & 480 \\
\hline $\mathrm{Mn}$ & 550 & 2400 & 1580 \\
\hline$N^{(b)}$ & -- & -- & $>350$ \\
\hline $\mathrm{Na}$ & 290 & 400 & 340 \\
\hline $\mathrm{Ni}$ & 330 & 520 & 430 \\
\hline $\mathrm{Ru}$ & 1.3 & 27 & 7 \\
\hline$S$ & -- & -- & $<19$ \\
\hline$S b^{(a)}$ & 310 & 580 & 480 \\
\hline $\mathrm{Se}$ & 80 & 430 & 210 \\
\hline Si & 630 & 1200 & 940 \\
\hline $\mathrm{Sr}$ & 250 & 520 & 380 \\
\hline Te & 49 & 80 & 60 \\
\hline $\mathrm{Ti}$ & 280 & 2300 & 1100 \\
\hline $\mathrm{Zn}$ & 290 & 360 & 350 \\
\hline
\end{tabular}

(a) Due to limitations of analyzing equipment, the DFs reported are minimum values based on the ICP detection limit.

(b) Unknown feed composition. Value given in mg of effluent $/ \mathrm{kg}$ of glass produced. 
The classical scattering aerosol spectrometer was used to characterize the off-gas loading and size distribution of entrained particulate matter during the LFCM-2 experiment. The results obtained from this instrument during a 15-min sampling interval are illustrated in Figure A.6. Assuming particulate sphericity and an average bulk density of $4 \mathrm{~g} / \mathrm{cm}^{3}$, the average off-gas loading during this measurement period was $7 \times 10^{-4} \mathrm{~g} / \mathrm{scf}$.

No noncondensible off-gas data was generated during the run.

$\underline{\text { LFCM-3 - NOVEMBER } 1980}$

This 24-h melter experiment was conducted to test the LFCM operational characteristics without lid heating. Effluent sampling was limited to the use of the off-gas scrub train previously described, and to the use of gas cylinders for obtaining grab samples of noncondensible gases. The analytical results obtained from these samples are summarized in Table A.4. This table

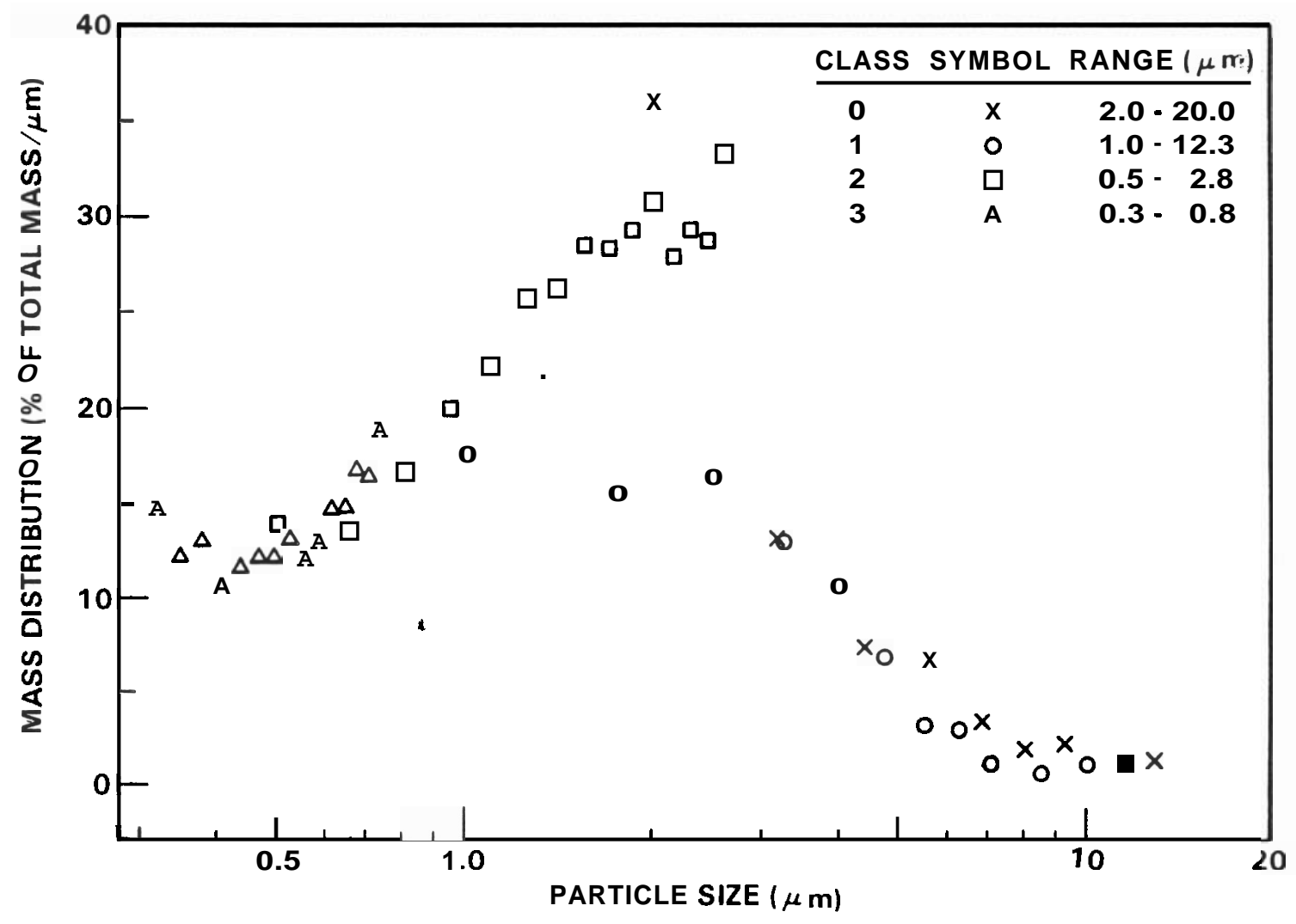

FIGURE A.6. LFCM-2 Mass-Size Particle Distribution 
TABLE A.4. LFCM-3 Decontamination Factors

\begin{tabular}{|c|c|c|}
\hline Element & Average DF & $\frac{\text { DF Ratio }}{\text { LFCM-3/LFCM-7 }}$ \\
\hline Al & 2400 & 1.6 \\
\hline B & 121 & 0.46 \\
\hline $\mathrm{Ca}$ & 1850 & 2.50 \\
\hline $\mathrm{Cd}$ & 84 & $<0.2$ \\
\hline C1 & 9 & 0.53 \\
\hline Cs & 7 & 0.18 \\
\hline $\mathrm{Fe}$ & 690 & 1.64 \\
\hline $\mathrm{Li}$ & 660 & 0.72 \\
\hline $\mathrm{Mg}$ & 1800 & 3.75 \\
\hline $\mathrm{Mn}$ & 3100 & 1.94 \\
\hline $\mathrm{Na}$ & 280 & 0.82 \\
\hline $\mathrm{Ni}$ & 430 & 1.00 \\
\hline Ru & 60 & 8.57 \\
\hline S & 5 & 0.26 \\
\hline Si & 2600 & 2.77 \\
\hline $\mathrm{Sr}$ & 1500 & 3.95 \\
\hline $\mathrm{Te}$ & 270 & 4.43 \\
\hline TOTA & 480 & 0.86 \\
\hline
\end{tabular}

presents the DFs associated with LFCM-3 feed components and compares these values to those obtained from the LFCM-2 test. DFs were higher during LFCM-3 than during LFCM-2 for most feed components, although the total oxide DFs of these two experiments are more or less comparable.

PSCM-1 - DECEMBER 1980

The 120-h PSCM-1 experiment represented the first test of the pilot-scale ceramic melter since it was converted to liquid feeding. No boosting techniques were employed during this December test. All pertinent operational parameters associated with this run are summarized in Table A.1. 
In preparation for this experiment, all appropriate off-gas-line components were preweighed so that the extent of off-gas deposition within the process lines could be assessed after completion of the run. However, very little deposition was found, as is illustrated in Figures A.7 through A.21. Figure $A 7$ is an off-gas-line schematic identifying the off-gas components which were disassembled for inspection at the end of the PSCM-1 test. Figures A.8 through A.21 are photographs of these components. The total deposition mass which was scraped from these components amounted to $68 \mathrm{~g}$. The analyses of these deposits were conducted by SRL. Table A5 summarizes these analytical results and compares them with the previous LFCM-2 deposits whenever possible.

\section{LOCATION OF PHOTOGRAPHS}

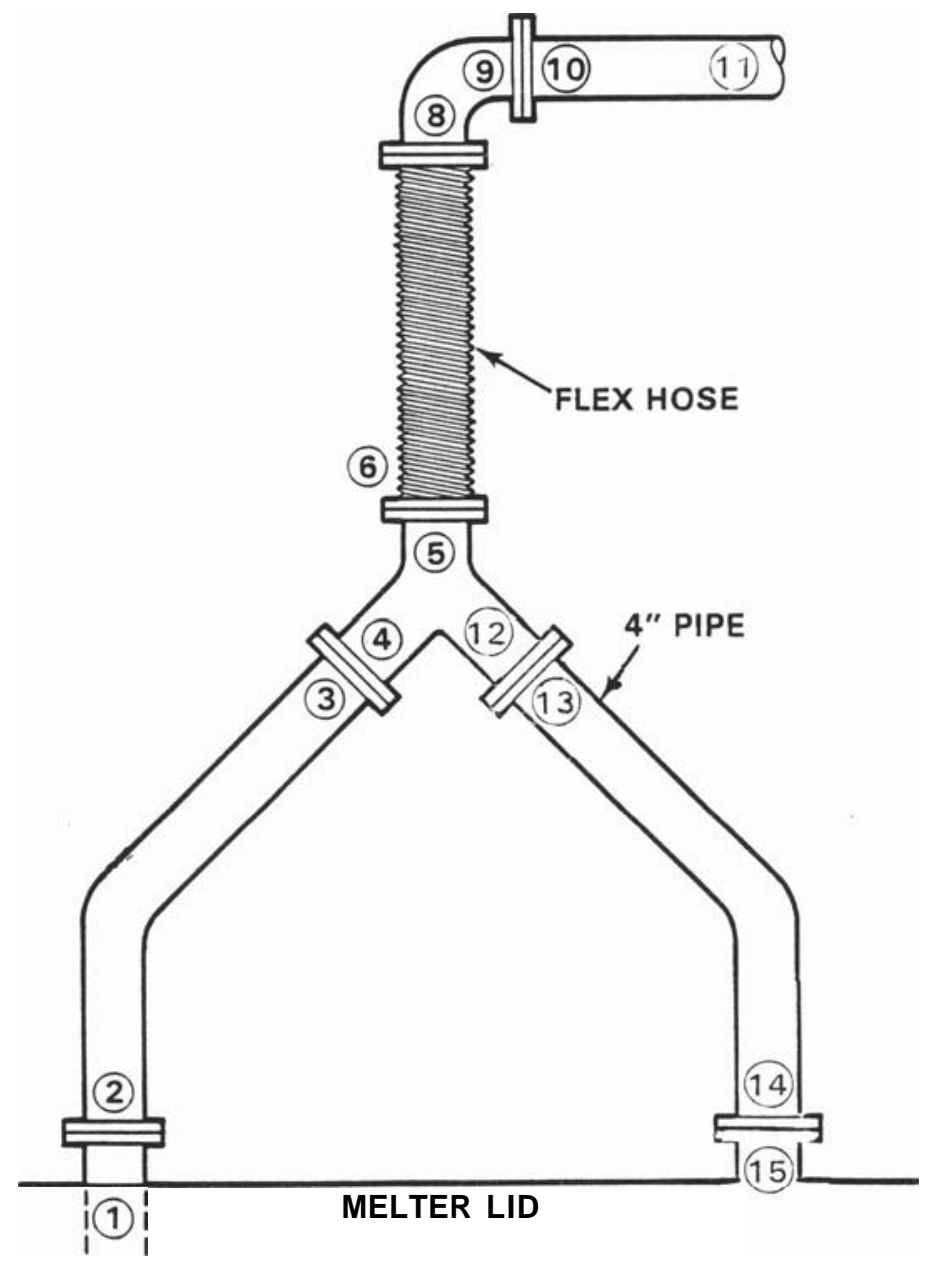

FIGURE A.7. PSCM-1 Off-Gas-Line Schematic 


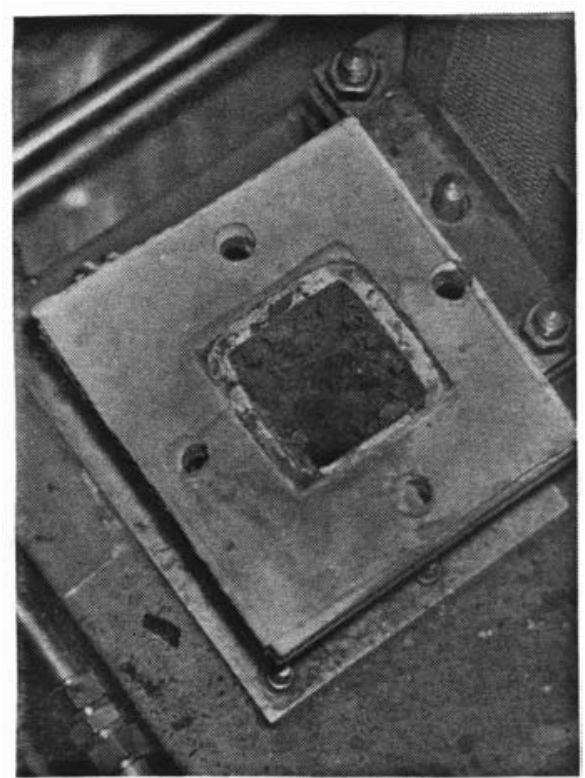

FIGURE A.8. PSCM-1 \#1

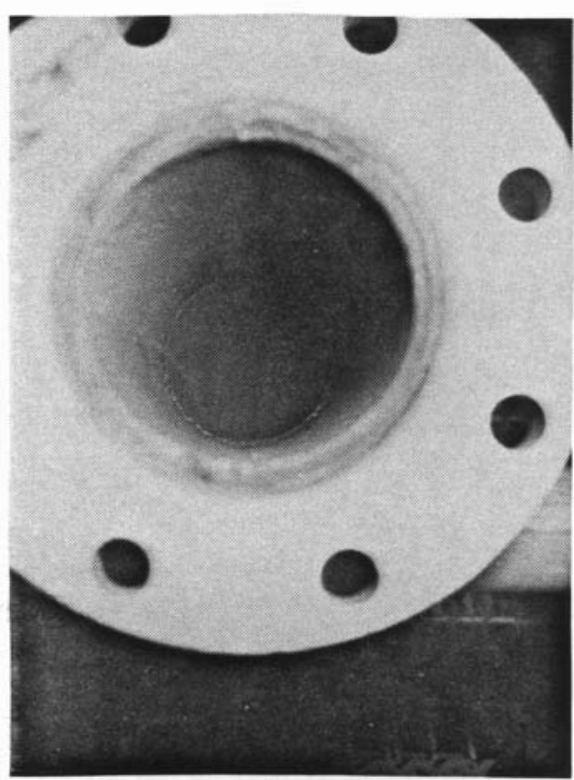

FIGURE A.IO. PSCM-1 \#3

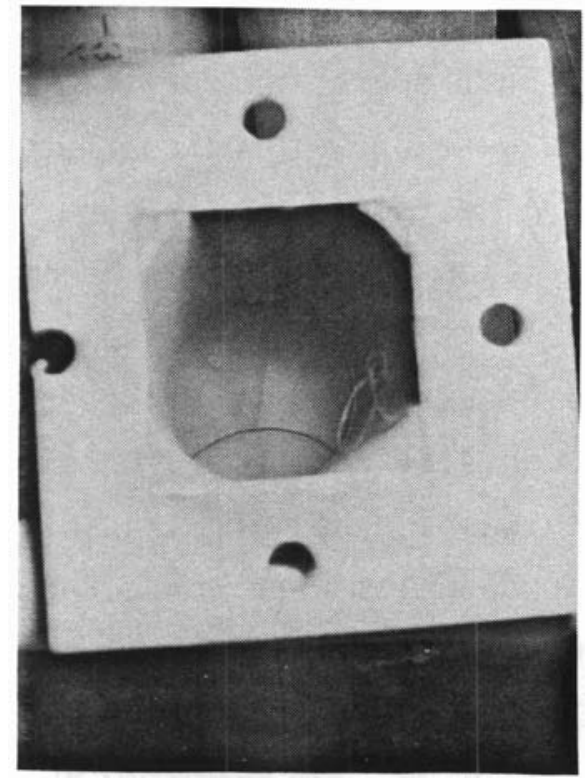

FIGURE A.9. PSCM-1 \#2

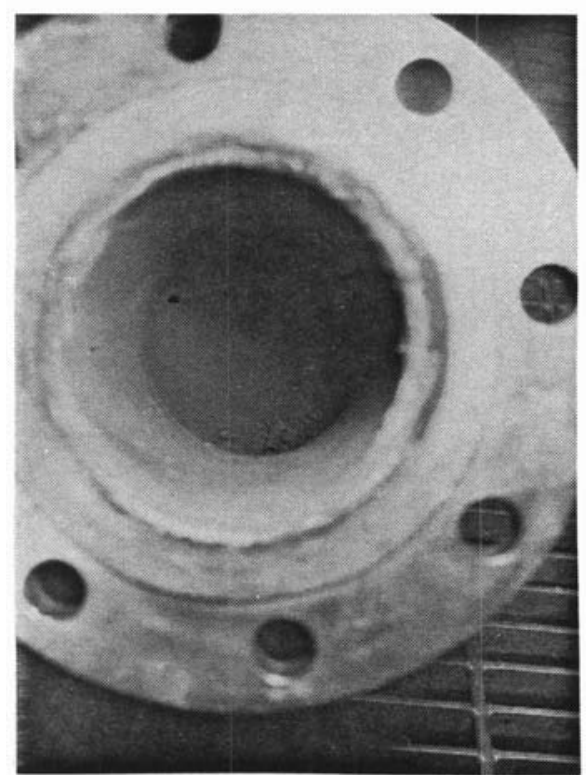

FIGURE A.11. PSCM-1 \#4 


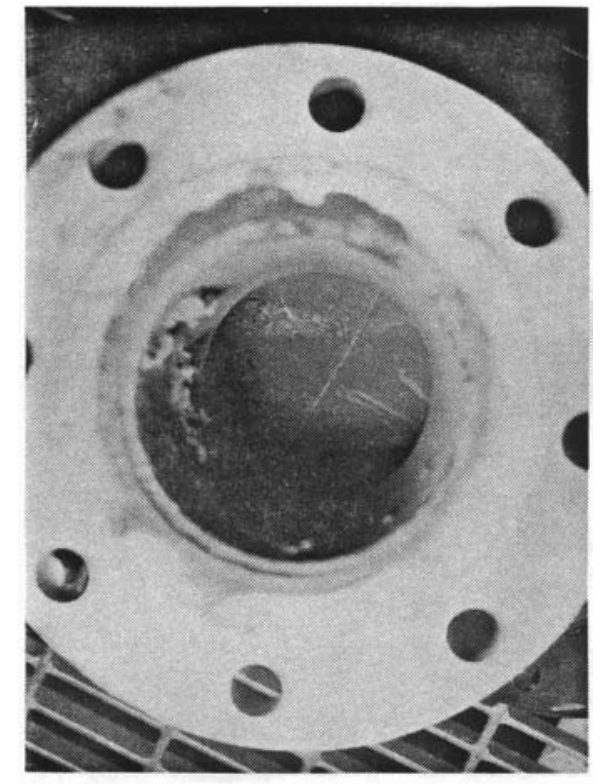

FIGURE A.12. PSCM-1 \#5

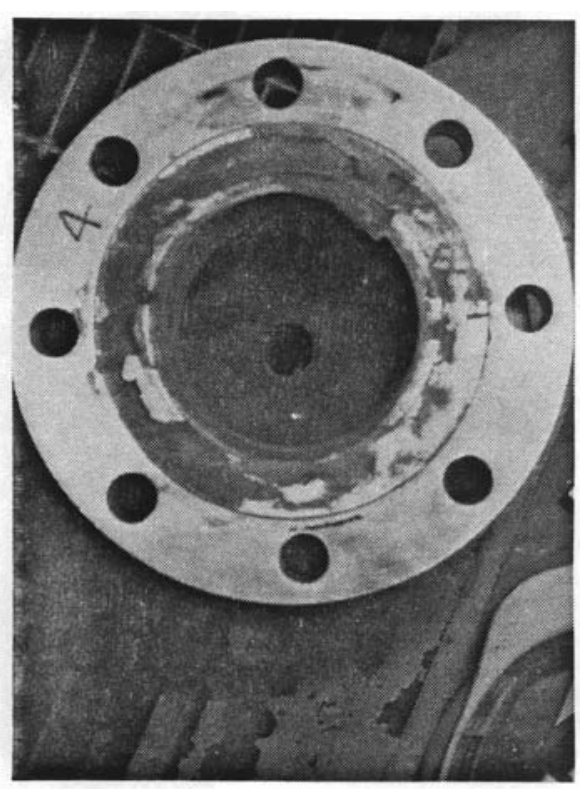

FIGURE A.14. PSCM-1 \#8

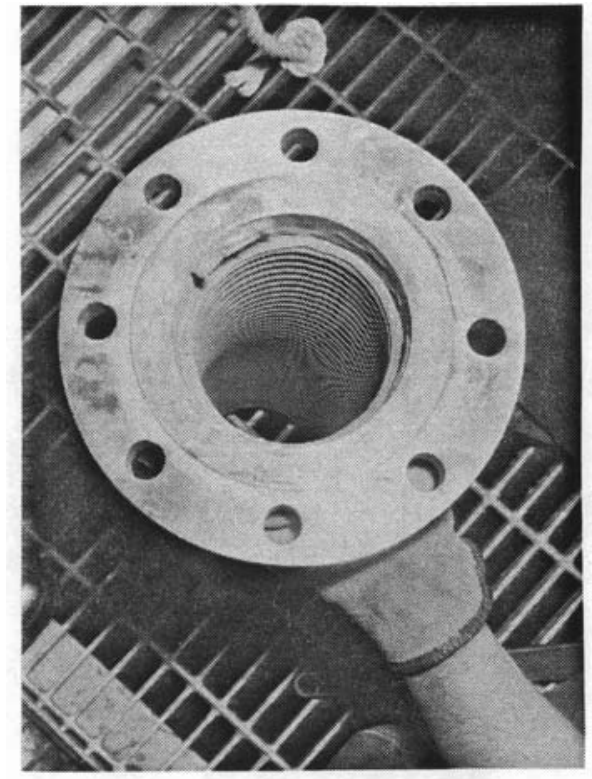

FIGURE A.13. PSCM-1 \#6

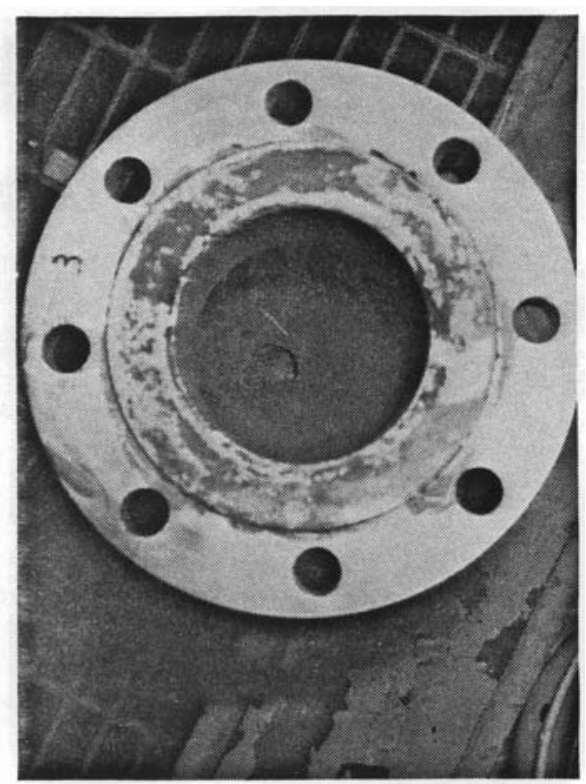

FIGURE A.15. PSCM-1 \#9 


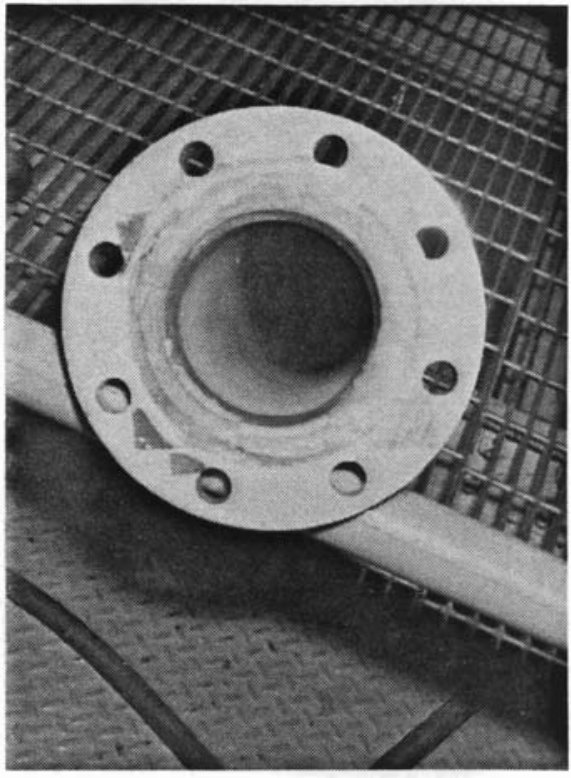

FIGURE A.16. PSCM- $1 \# 10$

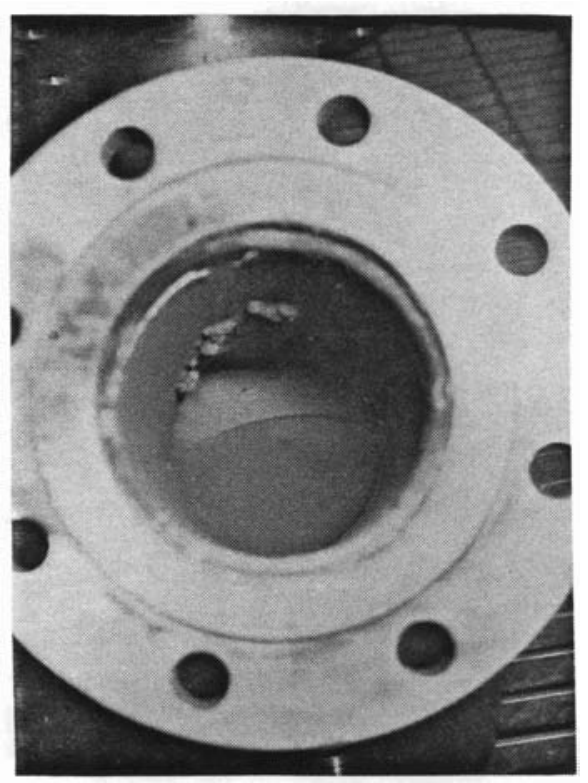

FIGURE A.18. PSCM-1 \#12

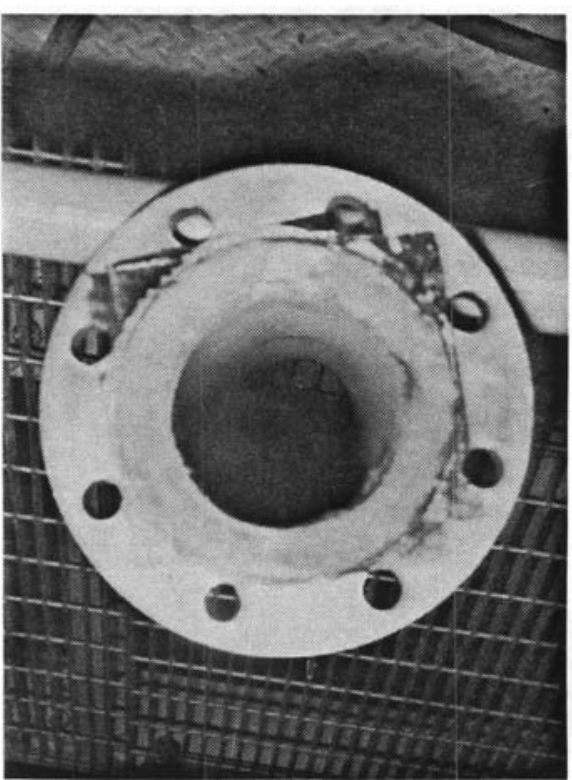

FIGURE A.17. PSCM-1 \#11

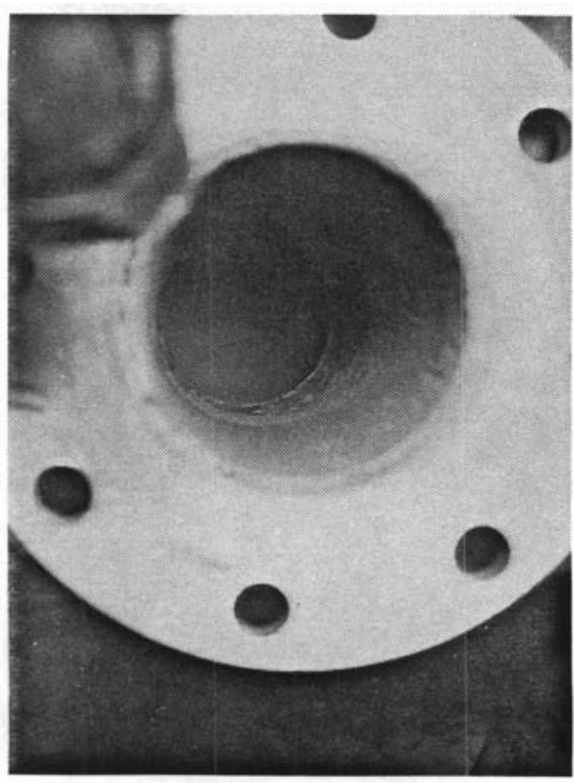

FIGURE A.19. PSCM-1 \#13 


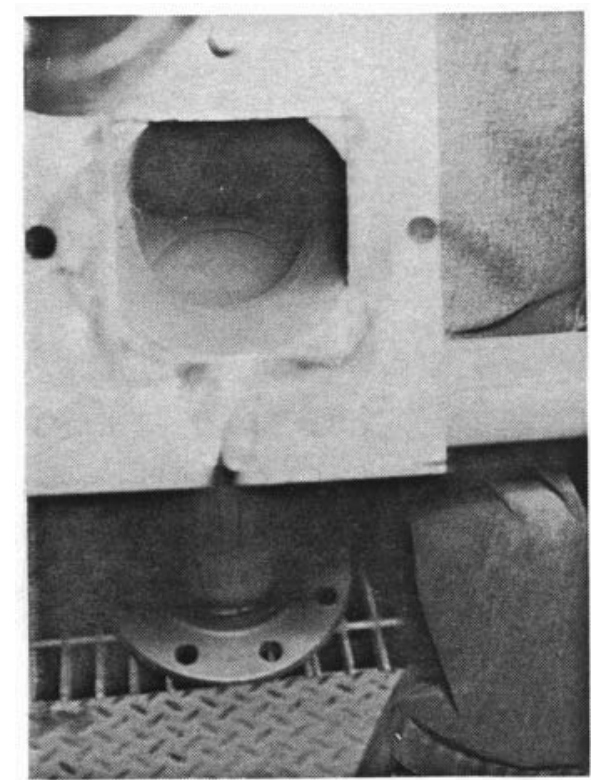

FIGURE A.20. PSCM-1 \#14

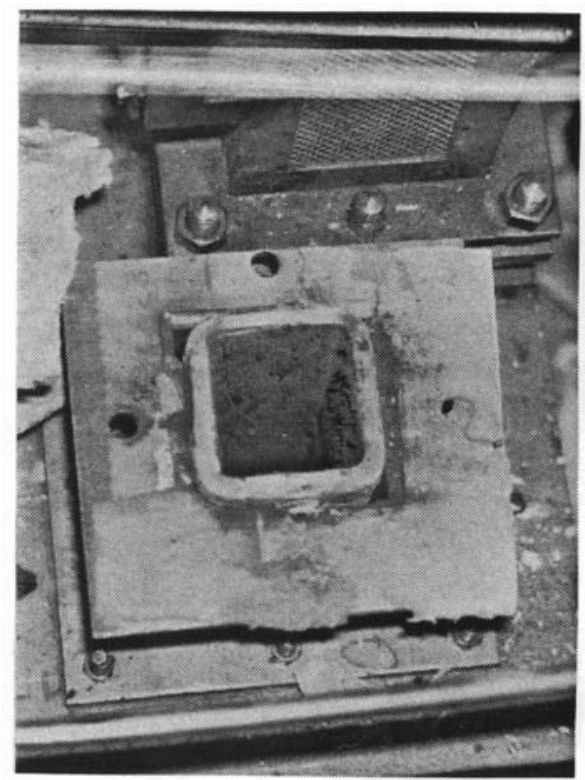

FIGURE A.21. PSCM-1 \#15

Idling deposits were also collected from these same process line components two months after completion of PSCM-1. These deposits were highly enriched with the semivolatile elements $\mathrm{Cs}, \mathrm{Ru}$, and $\mathrm{Te}$, and the anion $\mathrm{SO}_{4}=$. These results are included in Table A5 for comparison.

The feed component DFs achieved with PSCM-1 are summarized in Table A.6. Again, these values are compared to those obtained from the two previous melter runs LFCM-2 and LFCM-3. Clearly, much less volatilization and entrainment occurred during PSCM-1 than in the two previous experiments discussed in this report.

Grab samples taken from PSCM-1 plenum were analyzed using a gas mass spectrometer. These results are summarized in Table A.7. Aeration of the feed slurry with $\mathrm{CO}_{2}$ and the oxidation of the coal component of the feed are responsible for the unusually high concentrations of $\mathrm{CO}_{2}$ in the melter plenum. Oxygen, on the average, appears to be slightly depleted with regard to room air, which is consistent with moderate inleakage rates and feed component oxidation. Although Sample B appears to be enriched in oxygen (relative to nitrogen), no observable frothing or reboil occurred during that or any other sampling period. 
TABLE A.5. PSCM-1 Process Line Deposits

\begin{tabular}{|c|c|c|c|c|}
\hline \multirow{2}{*}{$\begin{array}{c}\text { Elemental } \\
\text { Oxides }\end{array}$} & \multicolumn{4}{|c|}{ Weight Percent } \\
\hline & $\overline{P S C M-1}$ & Idling & LFCM-2 & Feed \\
\hline $\mathrm{Al}_{2} \mathrm{O}_{3}$ & -- & 1.2 & 1.7 & 3.6 \\
\hline $\mathrm{B}_{2} \mathrm{O}_{3}$ & 4.6 & 14.2 & 4.6 & 9.9 \\
\hline $\mathrm{CaO}$ & -- & 0.22 & 4.4 & 1.2 \\
\hline CdO & -- & 0.02 & -- & 0.01 \\
\hline $\mathrm{Cl}^{-}$ & -- & 0.5 & 10.0 & -- \\
\hline $\mathrm{Cr}_{2} \mathrm{O}_{3}$ & -- & 0.57 & 0.42 & 0.02 \\
\hline $\mathrm{Cs}_{2} \mathrm{O}$ & 0.80 & 3.7 & 0.26 & 0.06 \\
\hline $\mathrm{F}^{-}$ & -- & 0.02 & 0.24 & -- \\
\hline $\mathrm{Fe}_{2} \mathrm{O}_{3}$ & 10.0 & 0.10 & 20.0 & 16.0 \\
\hline $\mathrm{LiO}_{2}$ & -- & 1.92 & 2.0 & 4.1 \\
\hline Mg0 & -- & $<0.05$ & 0.22 & 1.4 \\
\hline $\mathrm{MnO}_{2}$ & -- & 0.05 & 1.2 & 3.8 \\
\hline $\mathrm{Na}_{2} \mathrm{O}$ & 20.0 & 31.0 & 17.0 & 15.5 \\
\hline NiO & -- & 0.25 & 2.5 & 1.5 \\
\hline $\mathrm{RuO}_{2}$ & -- & 0.82 & 0.30 & 0.02 \\
\hline $\mathrm{Sb}_{2} \mathrm{O}_{3}$ & -- & $<0.01$ & -- & 0.008 \\
\hline $\mathrm{SiO}_{2}$ & -- & $<0.02$ & 31.0 & 44.0 \\
\hline $\mathrm{SO}_{4}=$ & -- & 62.0 & 1.9 & -- \\
\hline Sro & -- & $<0.005$ & 0.04 & 0.02 \\
\hline $\mathrm{TeO}_{2}$ & -- & 0.70 & 0.07 & 0.01 \\
\hline Ti0 & -- & $<0.01$ & 0.07 & 0.70 \\
\hline Zno & -- & 0.02 & 0.08 & 0.008 \\
\hline
\end{tabular}

LFCM-4 - JANUARY 1981

LFCM-4 was a 120-h experiment using I id heaters to boost feeding rates and an off-gas cooling nozzle to maintain the melter exhaust temperature at $375^{\circ} \mathrm{C}$. One objective of this run was to evaluate the effect of off-gas temperature upon process-line deposition rates. The deposits that formed within the components making up the melter exhaust line are shown in Figures A.23 through A.27. The location of these components relative to the melter are identified in Figure A.22. Although the deposition rate during this run was 
TABLE A.6. PSCM-1 Decontamination Factors

\begin{tabular}{|c|c|c|c|}
\hline \multirow[b]{2}{*}{ Element } & \multirow{2}{*}{$\begin{array}{c}\begin{array}{c}\text { PSCM-1 } \\
\text { Average DF }\end{array} \\
\end{array}$} & \multicolumn{2}{|c|}{$\frac{\text { DF Ratios }}{2}$} \\
\hline & & PSCM-1/LFCM-2 & PSCM-1/LFCM-3 \\
\hline Al & 11000 & 7.33 & 4.58 \\
\hline B & 210 & 0.81 & 1.74 \\
\hline $\mathrm{Ca}$ & 1800 & 2.49 & 1.00 \\
\hline $\mathrm{Cd}$ & 190 & 0.56 & 2.26 \\
\hline c1 & 3.1 & 0.13 & 0.34 \\
\hline Cs & 50 & 1.28 & 7.28 \\
\hline $\mathrm{Fe}$ & 3800 & 9.05 & 5.51 \\
\hline Li & 1900 & 2.06 & 2.88 \\
\hline $\mathrm{Mg}$ & 9000 & 18.80 & 5.00 \\
\hline $\mathrm{Mn}$ & 5700 & 3.56 & 1.84 \\
\hline $\mathrm{Na}$ & 830 & 2.44 & 2.96 \\
\hline $\mathrm{Ni}$ & 1500 & 3.49 & 3.49 \\
\hline $\mathrm{Ru}$ & 32 & 4.57 & 0.53 \\
\hline$S$ & 1.0 & 0.05 & 0.20 \\
\hline Si & 15000 & 15.96 & 5.77 \\
\hline $\mathrm{Sr}$ & 7400 & 19.47 & 4.93 \\
\hline Te & 170 & 2.79 & 0.63 \\
\hline TOTAL & 1140 & 2.04 & 2.38 \\
\hline
\end{tabular}

TABLE A.7. PSCM-1 Noncondensible Off-Gas Results

\begin{tabular}{|c|c|c|c|c|c|c|}
\hline \multicolumn{7}{|c|}{ Molar Composition, \% (dry) } \\
\hline Sample & $\mathrm{CO}_{2}$ & $\mathrm{Ar}$ & $\mathrm{O}_{2}$ & $\mathrm{~N}_{2}$ & $\mathrm{CO}$ & $\mathrm{H}_{2}$ \\
\hline A & 2.86 & 1.06 & 7.11 & 88.9 & $<0.01$ & 0.08 \\
\hline B & 6.35 & 0.88 & 19.8 & 73.0 & $<0.01$ & $<0.01$ \\
\hline c & 1.81 & 0.96 & 17.0 & 80.1 & $<0.01$ & 0.03 \\
\hline D & 4.54 & 0.95 & 14.9 & 79.6 & $<0.01$ & $<0.0$ \\
\hline $\mathrm{F}$ & .50 & 1.03 & 11.8 & 85.6 & $<0.01$ & \\
\hline
\end{tabular}




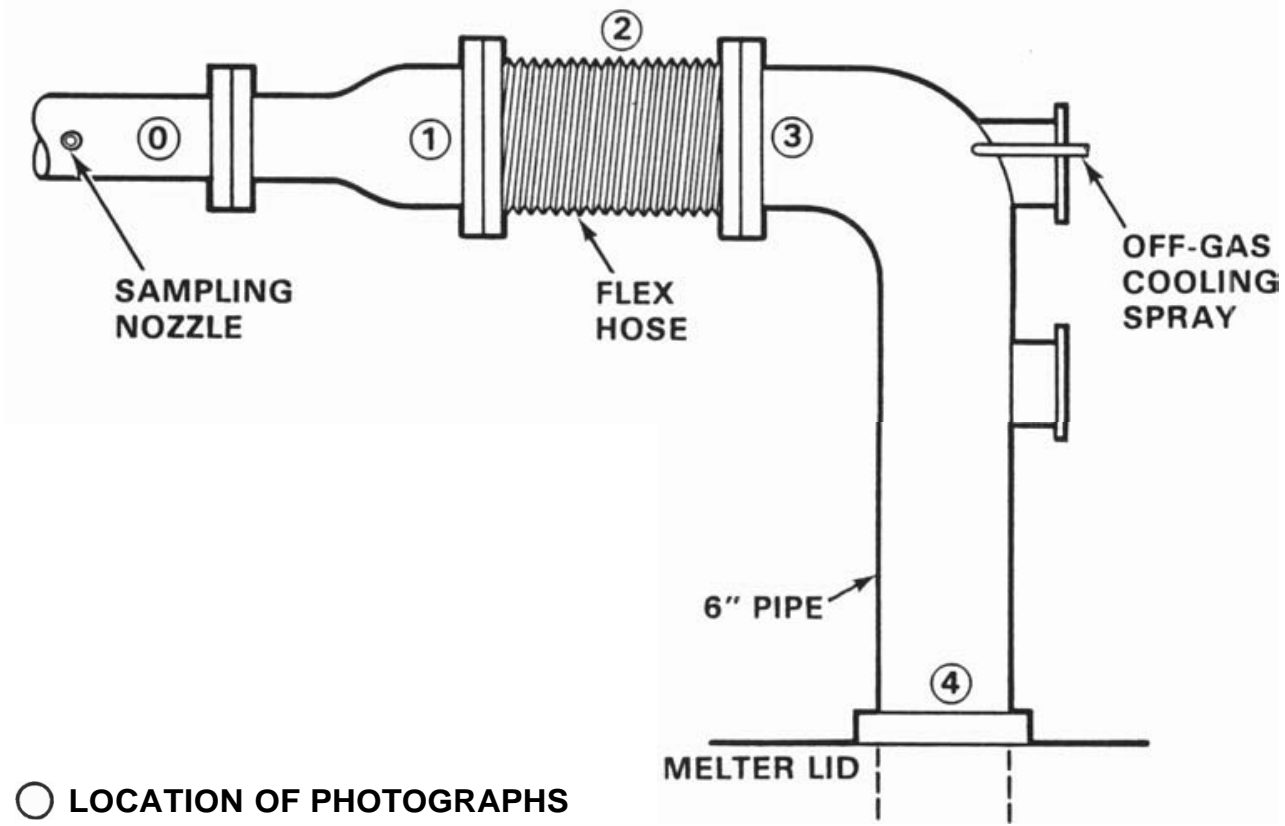

FIGURE A.22. LFCM-4 Off-Gas-Line Schematic

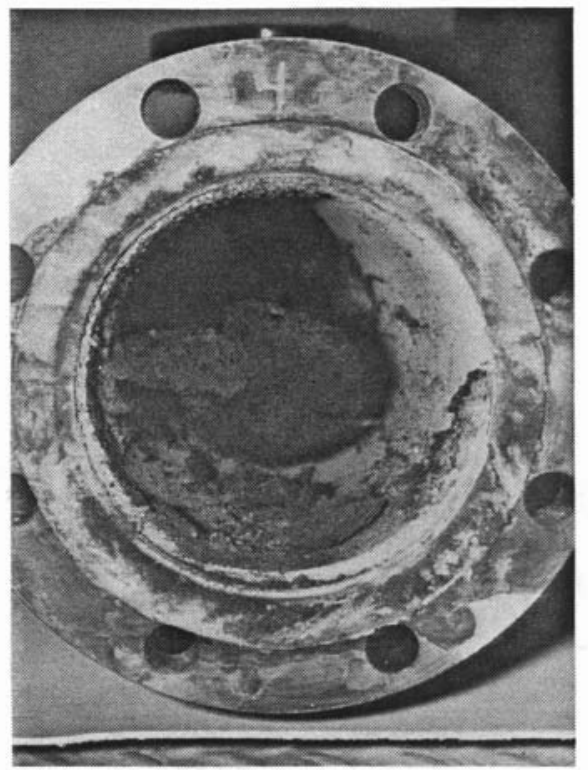

FIGURE A.23. LFCM-4 \#4

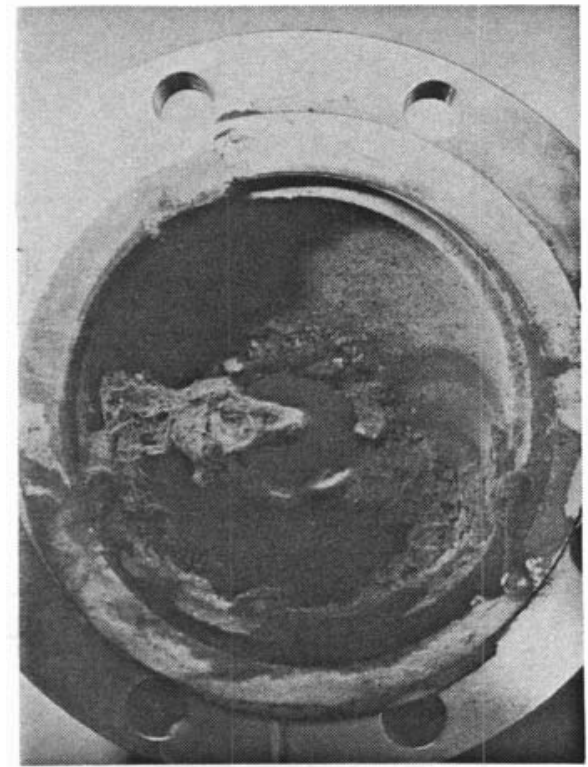

FIGURE A.24. LFCM-4 \#3 


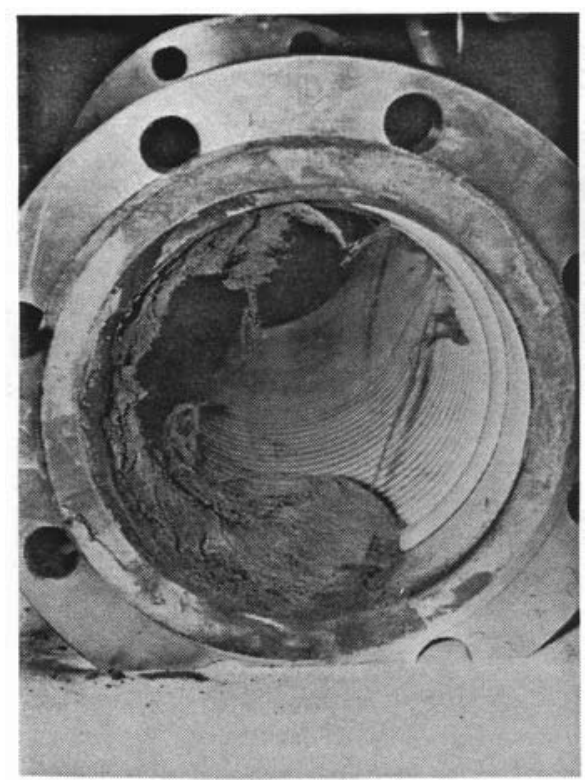

FIGURE A.25. LFCM- 4 \#2

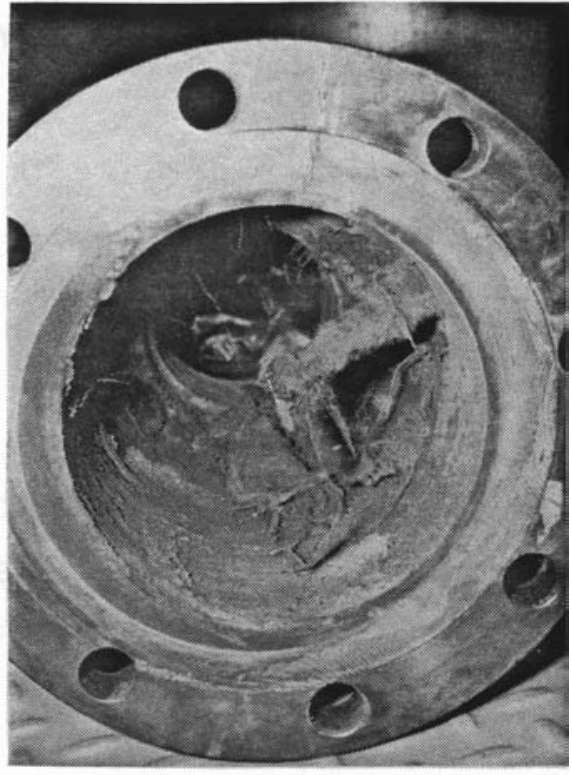

FIGURE A.26. LFCM-4 \#1

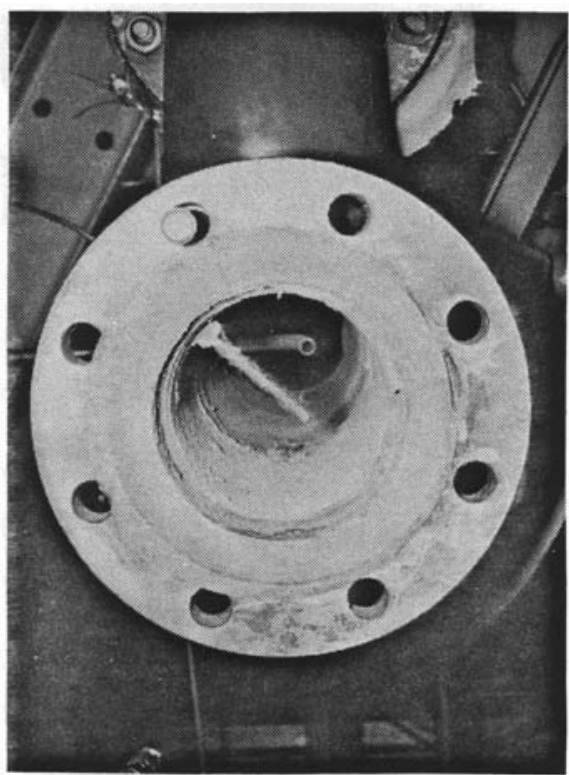

FIGURE A.27. LFCM-4 \#0 
greater than in the previous PSCM-2 experiment, the total quantity of material deposited was only $560 \mathrm{~g}(-1 \mathrm{lb})$, which is a vast improvement over the $5.9-\mathrm{kg}$ (13-1b) deposit formed during LFCM-2. The composition of the material collected from these pipe components is summarized in Table A.8, and is compared with previously obtained process-line deposition data. It is clear from this table that all melter-generated pipe deposits investigated to date possess comparable compositions.

Total feed component DFs obtained for the LFCM-4 test are summarized in Table A.9. These values are also compared with DF results obtained from a11 previous experiments described in this report. Although overall volatilization

TABLE A.8. LFCM-4 Pipe Deposition Composition

\begin{tabular}{|c|c|c|c|c|}
\hline \multirow{2}{*}{$\begin{array}{c}\text { Elemental } \\
\text { Oxides }\end{array}$} & \multicolumn{4}{|c|}{ Weight Percent } \\
\hline & LFCM-4 & PSCM-1 & LFCM-2 & Feed \\
\hline $\mathrm{Al}_{203}$ & 2.0 & -- & 1.7 & 3.5 \\
\hline $\mathrm{B}_{2} \mathrm{O}_{3}$ & 5.6 & 4.6 & 4.6 & 9.9 \\
\hline $\mathrm{CaO}$ & 6.5 & -- & 4.4 & 1.2 \\
\hline $\mathrm{CdO}$ & 0.08 & -- & -- & 0.01 \\
\hline $\mathrm{Cr}_{2} \mathrm{O}_{3}$ & 0.31 & -- & -- & 0.02 \\
\hline $\mathrm{Cs}_{2} \mathrm{O}$ & 0.31 & 0.80 & 0.26 & 0.06 \\
\hline $\mathrm{Fe}_{2} \mathrm{O}_{3}$ & 14.0 & 10.0 & 20.0 & 16.0 \\
\hline Li0 & 3.4 & -- & 2.0 & 4.1 \\
\hline MgO & 2.5 & -- & 0.22 & 1.4 \\
\hline $\mathrm{MnO}_{2}$ & 3.4 & -- & 1.2 & 3.8 \\
\hline $\mathrm{Na}_{2} \mathrm{O}$ & 15.0 & 20.0 & 17.0 & 16.0 \\
\hline NiO & -- & -- & 2.5 & 1.5 \\
\hline $\mathrm{RuO}_{2}$ & 0.16 & -- & 0.3 & 0.02 \\
\hline $\mathrm{Sb}_{2} \mathrm{O}_{3}$ & -- & -- & -- & 0.003 \\
\hline sio & 31.0 & -- & 31.0 & 44.0 \\
\hline Sr0 & 0.05 & -- & 0.04 & 0.02 \\
\hline $\mathrm{TeO}_{2}$ & 0.11 & -- & 0.07 & 0.01 \\
\hline TiO & 0.11 & -- & 0.07 & 0.70 \\
\hline $\mathrm{ZrO}_{2}$ & 0.29 & & & -- \\
\hline
\end{tabular}


TABLE A.9. LFCM-4 Decontamination Factors

\begin{tabular}{|c|c|c|c|c|}
\hline \multirow[b]{2}{*}{ Element } & \multirow{2}{*}{$\begin{array}{l}\text { LFCM-4 } \\
\text { Average } \\
\text { DF } \\
\end{array}$} & \multicolumn{3}{|c|}{ DF Ratio } \\
\hline & & $\begin{array}{l}\frac{\text { LFCM-4 }}{\text { LFCM-2 }} \\
\end{array}$ & $\begin{array}{l}\text { LFCM-4 } \\
\text { LFCM-3 }\end{array}$ & $\frac{\text { LFCM-4 }}{\text { PSCM-1 }}$ \\
\hline A1 & 530 & 0.35 & 0.22 & 0.05 \\
\hline B & 130 & 0.5 & 1.07 & 0.62 \\
\hline $\mathrm{Ca}$ & 260 & 0.35 & 0.14 & 0.14 \\
\hline $\mathrm{Cd}$ & 70 & $<0.20$ & 0.83 & 0.37 \\
\hline $\mathrm{C} 1$ & 2.2 & 0.13 & 0.24 & 0.71 \\
\hline Cs & 60 & 1.42 & 8.14 & 1.12 \\
\hline $\mathrm{Fe}$ & 260 & 0.62 & 0.38 & 0.07 \\
\hline Li & 310 & 0.34 & 0.47 & 0.16 \\
\hline $\mathrm{Mg}$ & 350 & 0.73 & 0.19 & 0.04 \\
\hline $\mathrm{Mh}$ & 420 & 0.26 & 0.14 & 0.07 \\
\hline $\mathrm{Na}$ & 340 & 1.00 & 1.21 & 0.41 \\
\hline $\mathrm{Ni}$ & 260 & 0.60 & 0.60 & 0.17 \\
\hline Ru & 26 & 3.7 & 0.43 & 0.81 \\
\hline$S$ & 1.0 & 0.05 & 0.20 & 1.0 \\
\hline$S b$ & 1800 & $<3.8$ & -- & -- \\
\hline$S \mathbf{i}$ & 420 & 0.45 & 0.16 & 0.03 \\
\hline $\mathrm{Sr}$ & 200 & 0.54 & 0.14 & 0.03 \\
\hline $\mathrm{Te}$ & 62 & 1.01 & 0.23 & 0.36 \\
\hline TOTAL & 290 & 0.52 & 0.60 & 0.25 \\
\hline
\end{tabular}

and entrainment is higher for LFCM-4 than for all the previous runs, the emissions of several semivolatiles are lower in LFCM-4 than they were in the two previous LFCM tests.

Particulate entrainment occurring during LFCM-4 was characterized by HEPA filtration. The particulate DFs listed in Table A.10 were calculated using both HEPA and off-gas-1ine deposition data. The elemental (oxide) composition of HEPA-trapped particulates is also listed in this table along with the feed makeup composition. Clearly, the composition of the HEPA-trapped material cannot be explained by a simple feed entrainment model. 
TABLE A.IO. LFCM-4 Particulate Data

\begin{tabular}{|c|c|c|c|}
\hline \multirow{2}{*}{$\begin{array}{c}\text { Elemental } \\
\text { Oxides }\end{array}$} & \multirow[b]{2}{*}{ DF } & \multicolumn{2}{|c|}{ Weight Percent } \\
\hline & & $\overline{\mathrm{HEPA}}$ & Feed \\
\hline $\mathrm{Al}_{2} \mathrm{O}_{3}$ & 1580 & 1.44 & 3.5 \\
\hline $\mathrm{B}_{2} \mathrm{O}_{3}$ & 1250 & 5.32 & 10.0 \\
\hline $\mathrm{CaO}$ & 620 & 1.34 & 1.2 \\
\hline $\mathrm{cdO}$ & 220 & 0.04 & 0.01 \\
\hline $\mathrm{Cr}_{2} \mathrm{O}_{3}$ & -- & 0.23 & 0.02 \\
\hline $\mathrm{Cs}_{2} \mathrm{O}$ & 100 & 0.70 & 0.06 \\
\hline $\mathrm{Fe}_{2} \mathrm{O}_{3}$ & 660 & 15.1 & 16.0 \\
\hline LiO & 840 & 3.21 & 4.1 \\
\hline $\mathrm{MgO}$ & 900 & 0.87 & 1.4 \\
\hline $\mathrm{MnO}_{2}$ & 1100 & 2.64 & 3.8 \\
\hline $\mathrm{Na}_{2} \mathrm{O}$ & 600 & 19.0 & 15.5 \\
\hline $\mathrm{NiO}$ & -- & -- & 1.5 \\
\hline $\mathrm{Ru}_{2} \mathrm{O}_{3}$ & 25 & 0.64 & 0.02 \\
\hline $\mathrm{Sb}_{2} \mathrm{O}_{3}$ & -- & -- & 0.008 \\
\hline $\mathrm{SeO}_{2}$ & -- & -- & 0.008 \\
\hline $\mathrm{SiO}_{2}$ & 1100 & 26.4 & 44.0 \\
\hline Sro & 595 & 0.20 & 0.02 \\
\hline $\mathrm{TeO}_{2}$ & 130 & 0.18 & 0.01 \\
\hline $\mathrm{TiO}_{2}$ & -- & 0.49 & 0.70 \\
\hline $\mathrm{ZnO}$ & -- & 0.06 & 0.008 \\
\hline $\mathrm{ZrO}_{2}$ & -- & 0.22 & -- \\
\hline TOTAL & 600 & & \\
\hline
\end{tabular}

A summary of the gas chromatographic analysis of the LFCM-4 plenum gas composition appears in Table A.ll. Due to the high melter inleakage rates, the oxygen-nitroyen ratios of the plenum gas samples were indistinguishable from room air during the melter run. As in PSCM-1, aeration of the feed slurry with $\mathrm{CO}_{2}$, and the oxidation of coal present in the feed, are responsible for the high concentrations of $\mathrm{CO}_{2}$ in the melter plenum.

Gas-scrubbing techniques were utilized for investigating the nature of idling emissions associated with LFCM-4. Sampling was begun 7 days after the 
TABLE A.II. LFCM-4 Noncondensible Off-Gas Composition

\begin{tabular}{|c|c|c|c|c|}
\hline \multirow[b]{2}{*}{ Date } & \multicolumn{3}{|c|}{ Percent } & \multirow[b]{2}{*}{$\mathrm{CO}$} \\
\hline & $\mathrm{CO}_{2}$ & $.0_{2}(\mathrm{a})$ & $\mathrm{N}_{2}$ & \\
\hline $01 / 20 / 81$ & 1.1 & 21.0 & 78.0 & $<10$ \\
\hline $01 / 20 / 81$ & 0.3 & 21.3 & 77.5 & $<10$ \\
\hline $01 / 21 / 81$ & 0.5 & 21.6 & 77.0 & $<10$ \\
\hline $01 / 22 / 81$ & 0.9 & 21.0 & 77.2 & $<10$ \\
\hline $01 / 22 / 81$ & 0.7 & 21.4 & 77.0 & 320 \\
\hline $01 / 22 / 81$ & 0.3 & 21.4 & 78.3 & 250 \\
\hline $01 / 23 / 81$ & 0.4 & 21.4 & 77.3 & $>100$ \\
\hline $01 / 23 / 81$ & 0.6 & 20.8 & 77.7 & 570 \\
\hline $01 / 23 / 81$ & 0.4 & 21.5 & 77.2 & 310 \\
\hline
\end{tabular}

(a) Includes $-1 \% \operatorname{Ar}$.

completion of LFCM-4, and again after 14 days. These data appear in Table A.12 along with the final composition of the LFCM-4 glass. The data in this table indicate that the semivolatile elements and compounds present in the molten glass matrix are escaping at rates which are proportional to their concentrations and volatilities.

\section{PSCM-2 - MARCH 1981}

One of the main objectives of PSCM-2 was to investigate the effect of combustion (propane) boosting upon melter feeding rates. The effect of using an off-gas cooling-spray nozzle upon melter emissions was also assessed. Further details concerning PSCM-2 operational parameters and constraints are summarized in Table A.1.

The nature of the off-gas-line deposits which were assessed after the run are summarized in Figures A.28 through A.42. Figure A.28 identifies the components of the process exhaust line where material deposits occurred. Figures A.29 through A.42 are photographs of these off-gas-line components. The largest deposition formed in the throat of the melter lid exhaust port. This deposit is thought to have resulted from the operation and positioning of the 
TABLE A.12. LFCM-4 Idling Emissions

\begin{tabular}{|c|c|c|c|}
\hline \multirow[b]{2}{*}{ Element } & \multicolumn{3}{|c|}{ Weight Percent } \\
\hline & 1 Week & 2 Weeks & Glass \\
\hline A1 & 0.06 & -- & 3.2 \\
\hline B & 10.2 & 2.2 & 5.6 \\
\hline $\mathrm{Ca}$ & 0.33 & 0.01 & 1.5 \\
\hline $\mathrm{Cd}$ & 0.17 & -- & 0.036 \\
\hline C1 & 1.07 & 71.0 & 0.19 \\
\hline $\mathrm{Cr}$ & 1.7 & 0.23 & -- \\
\hline Cs & 6.7 & 1.6 & 0.06 \\
\hline $\mathrm{Fe}$ & 8.3 & 0.20 & 20.0 \\
\hline K & 1.5 & -- & -- \\
\hline$L \mathbf{i}$ & 2.8 & 0.78 & 3.2 \\
\hline $\mathrm{Mg}$ & -- & -- & 1.5 \\
\hline $\mathrm{Mn}$ & 0.12 & 0.002 & 5.2 \\
\hline $\mathrm{Na}$ & 61.7 & 18.7 & 20.0 \\
\hline $\mathrm{Ni}$ & 0.82 & 0.04 & 2.2 \\
\hline $\mathrm{Ru}$ & 0.11 & 0.02 & 0.006 \\
\hline$S$ & 0.21 & 1.4 & -- \\
\hline Sb & -- & -- & 0.03 \\
\hline Si & 2.9 & 1.0 & 37.0 \\
\hline Sr & -- & -- & 0.04 \\
\hline $\mathrm{Te}$ & 1.0 & 0.13 & 0.07 \\
\hline $\mathrm{Ti}$ & 0.03 & -- & -- \\
\hline $\mathrm{Zr}$ & 0.02 & -- & -- \\
\hline
\end{tabular}

* Calculated from a11 detectable elements.

off-gas cooling nozzle just downstream from the plug formation site. Total depositions in the off-gas-line, including as much of the lid plug as could be collected, amounted to $-2 \mathrm{~kg}$, which represents $0.1 \%$ of the total oxides fed to the melter during this experiment.

The composition of the deposits collected from PSCM-2 off-gas-line components is summarized in Table A.13. Table A.14 compares the weighted, average 


\section{LOCATION OF PHOTOGRAPHS}

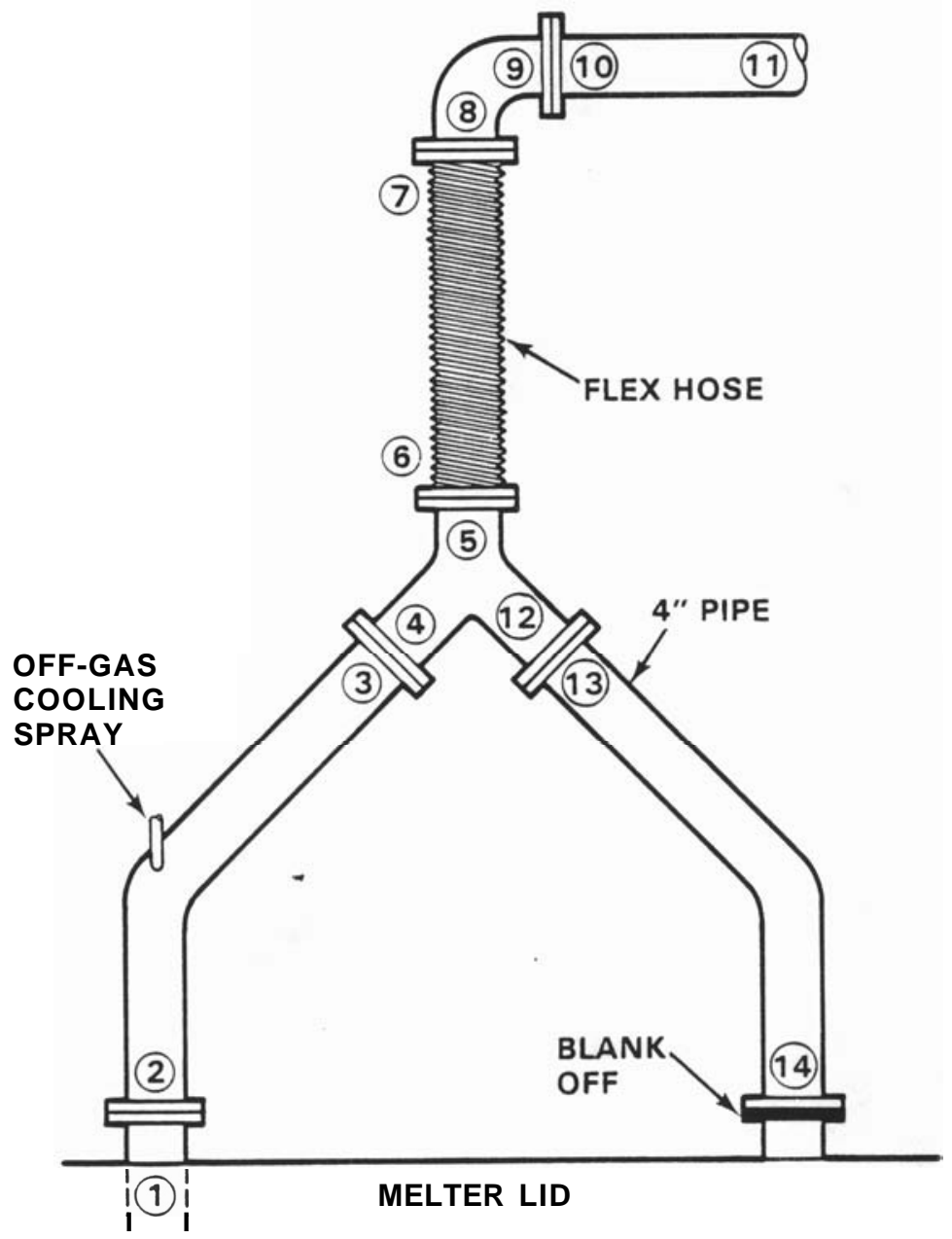

FIGURE A.28. PSCM-2 Off-Gas-Line Schematic

composition of these PSCM-2 deposits with the off-gas-line deposits formed in previous melter experiments. Composition of all off-gas-1ine deposits are similar, but not strictly representative of the feed.

Experimental feed component DFs determined during PSCM-2 are listed in Table A.15, where they are compared to all previous melter runs discussed in this report. It is clear from this table that combustion boosting, in conjunction with increased feeding rates, has dramatically increased effluent 


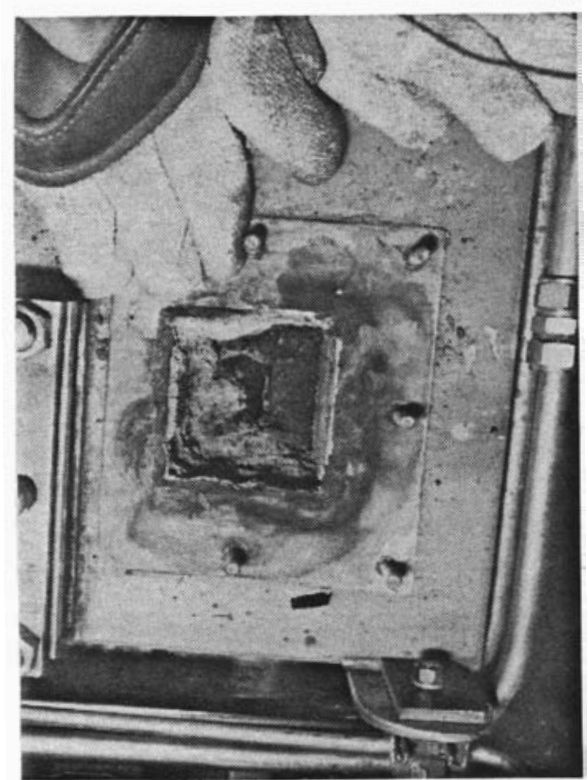

FIGURE A.29. PSCM-2 \#1

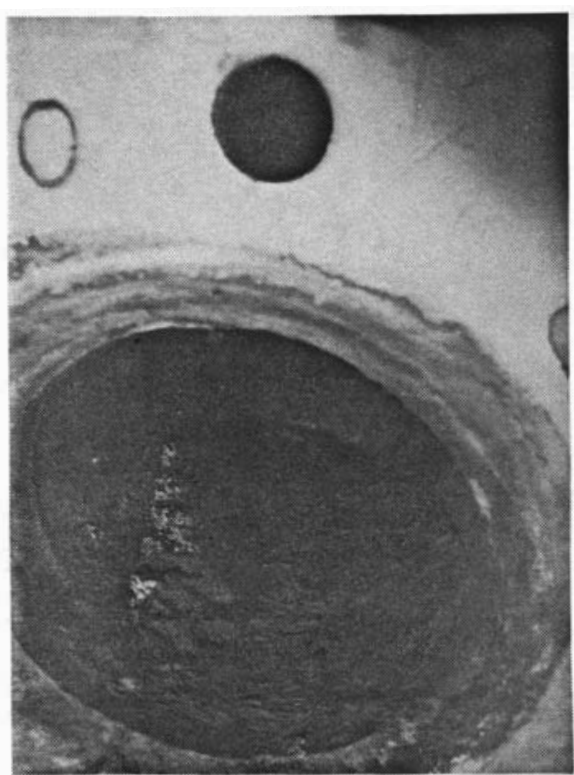

FIGURE A.31. PSCM-2 \#3

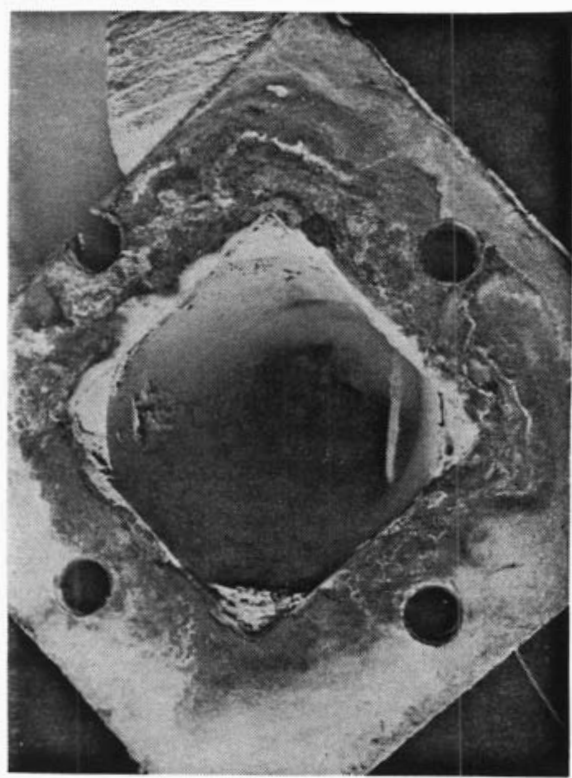

FIGURE A.30. PSCM-2 \#2

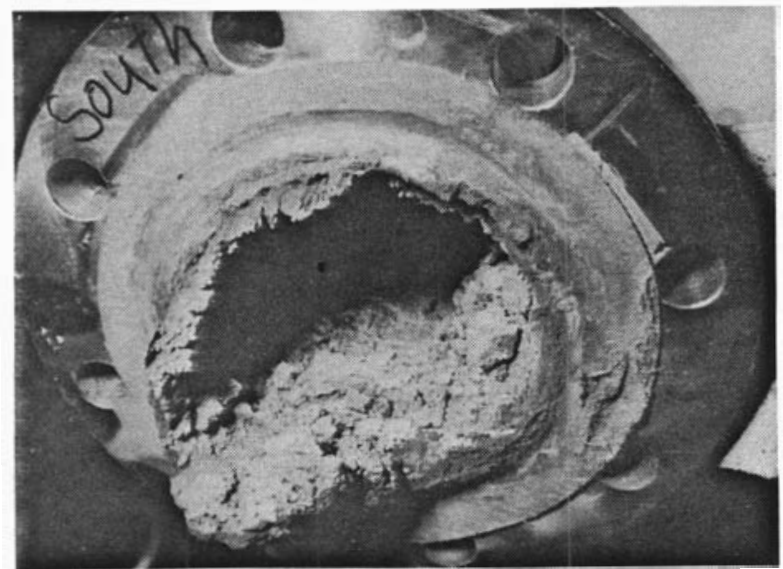

FIGURE A.32. PSCM-2 \#4 


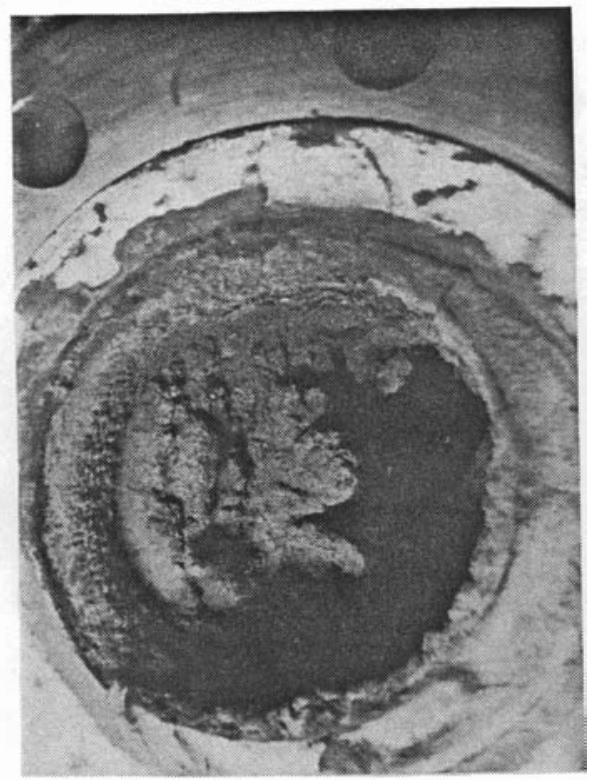

FIGURE A.33. PSCM- 2 \#5

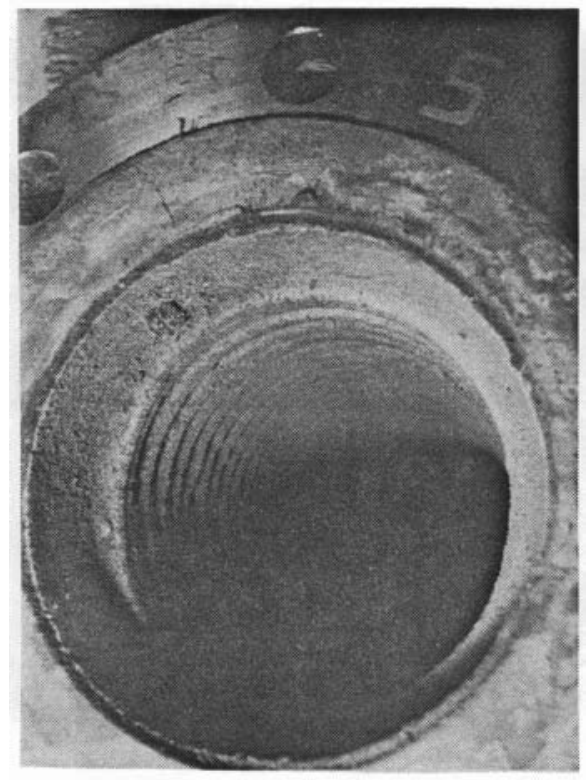

FIGURE A.35. PSCM-2 \#7

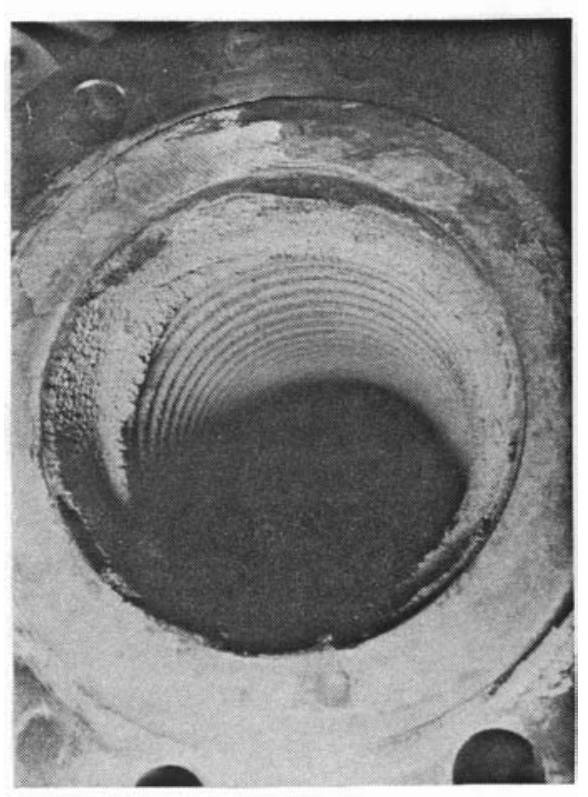

FIGURE A.34. PSCM-2 \#6

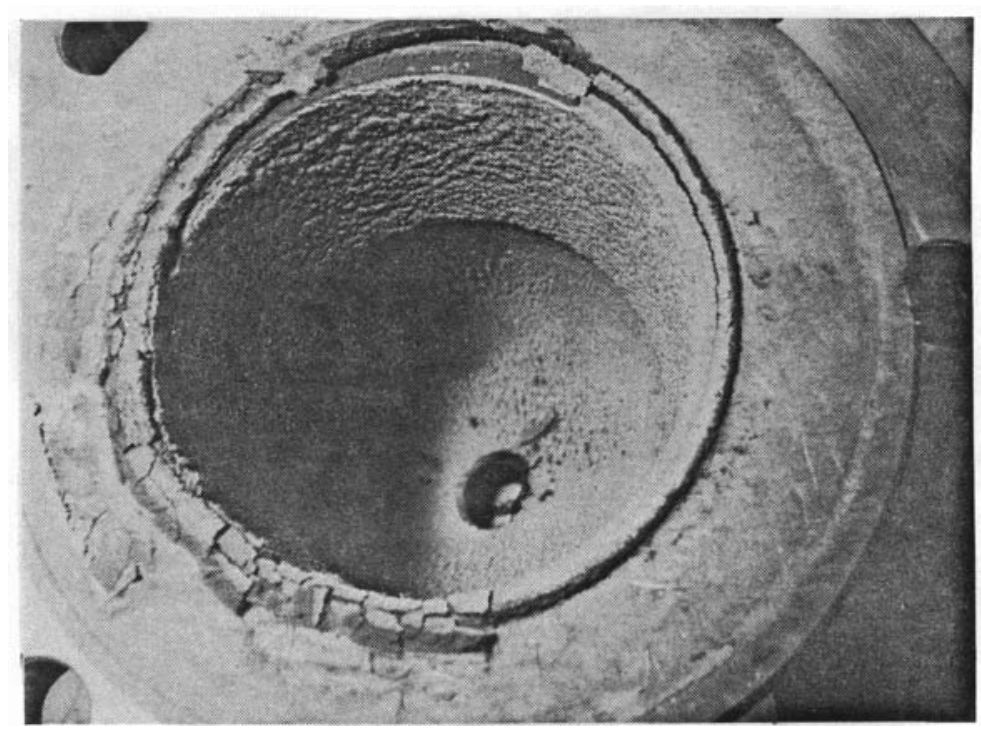

FIGURE A.36. PSCM-2 \#8 


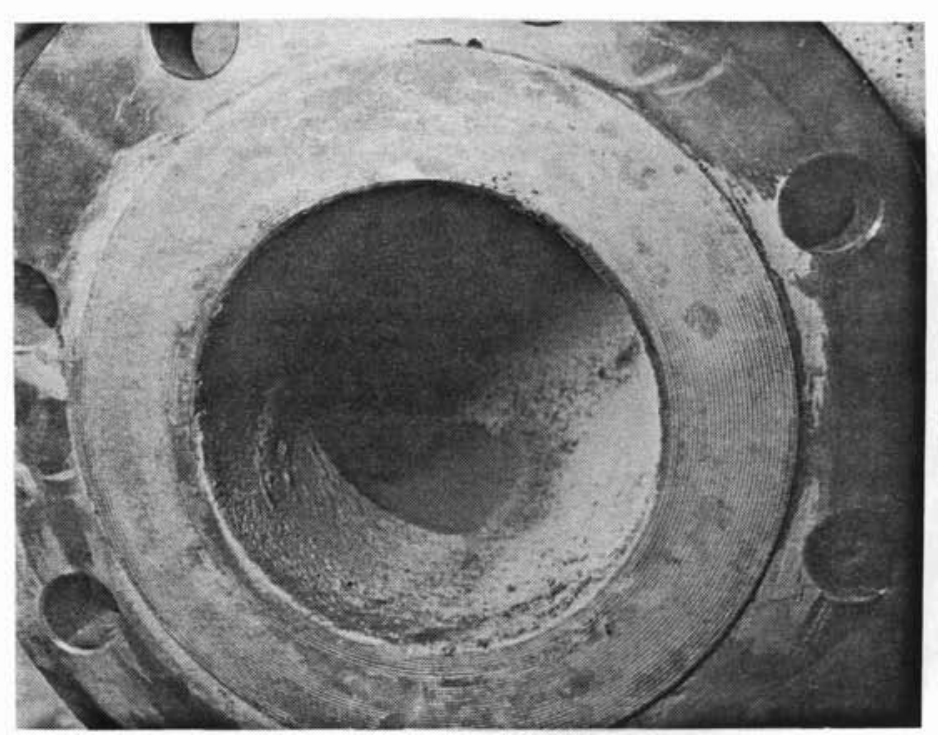

FIGURE A.37. PSCM-2 \#9

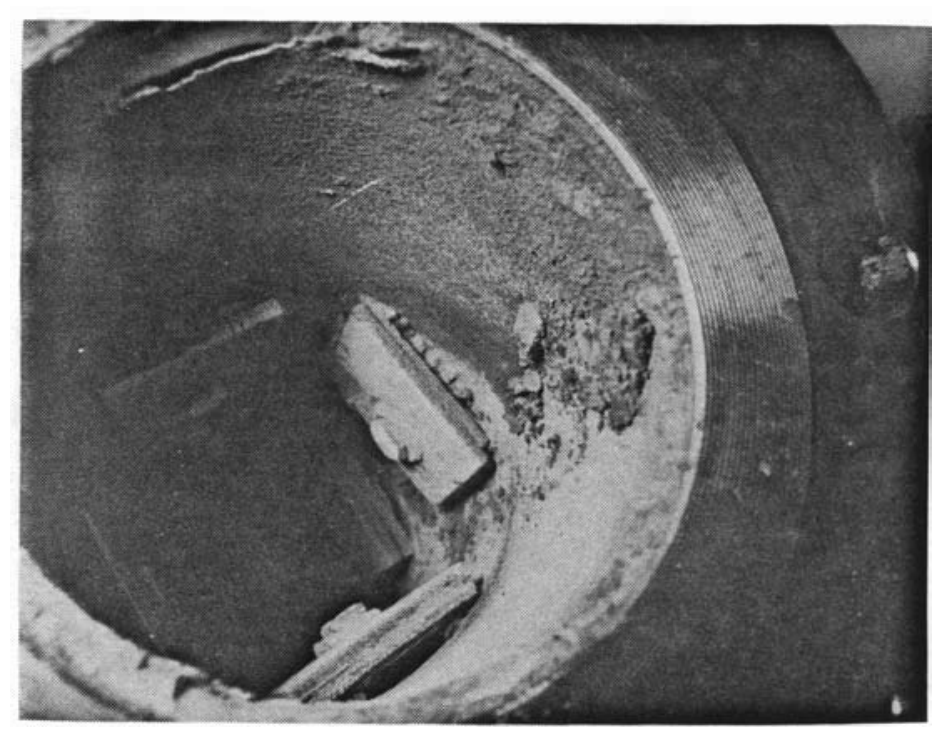

FIGURE A.39. PSCM-2 \#11

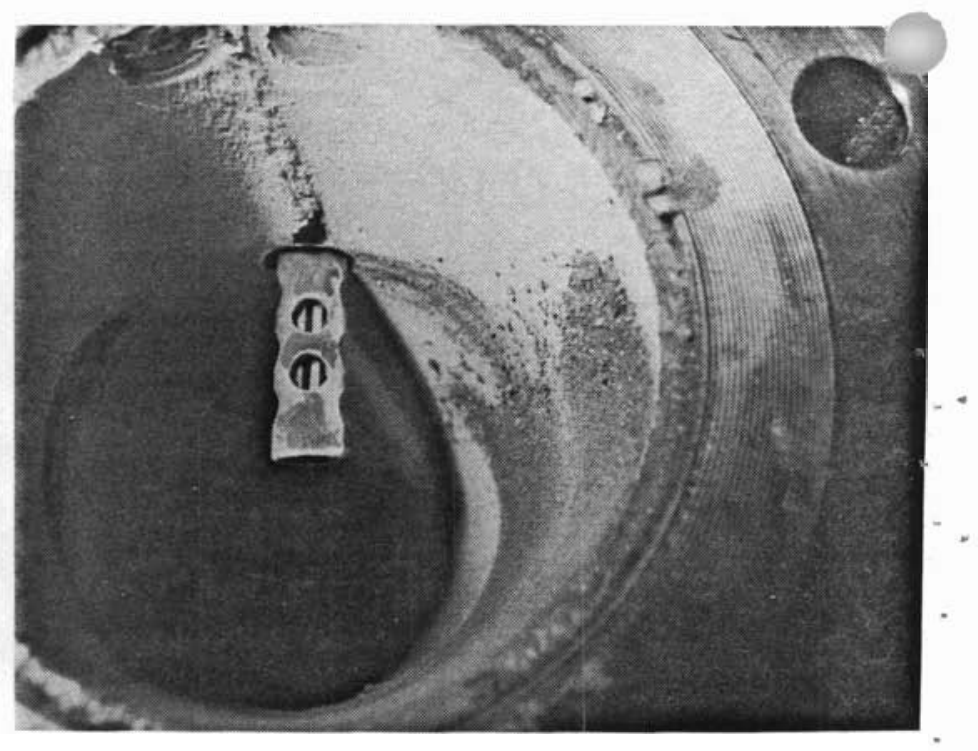

FIGURE A.38. PSCM-2 \#10

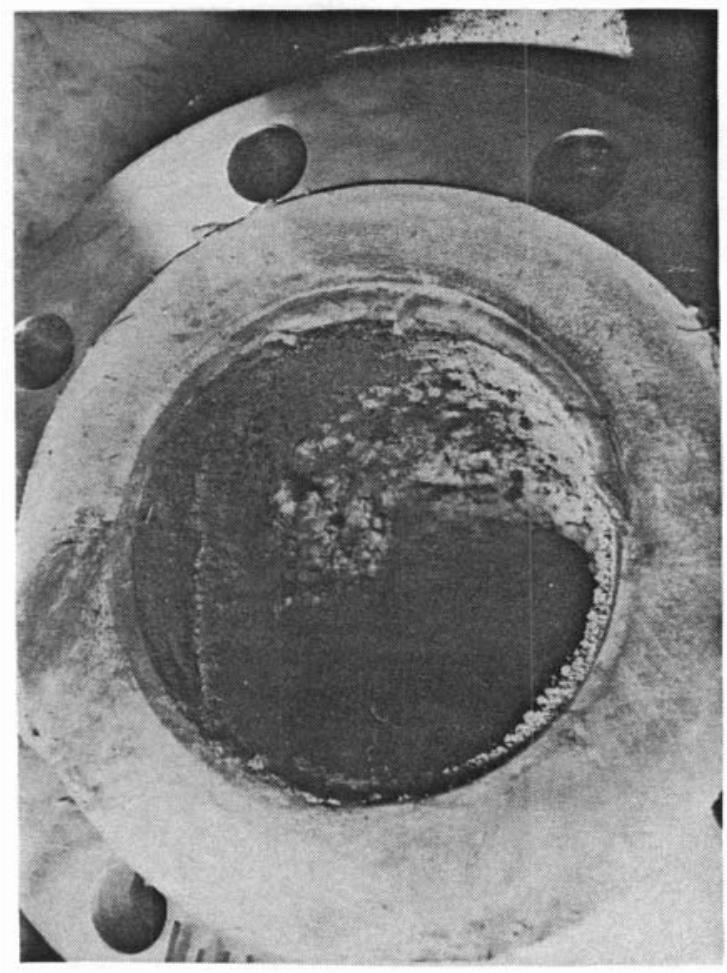

FIGURE A.40. PSCM-2 \#12 


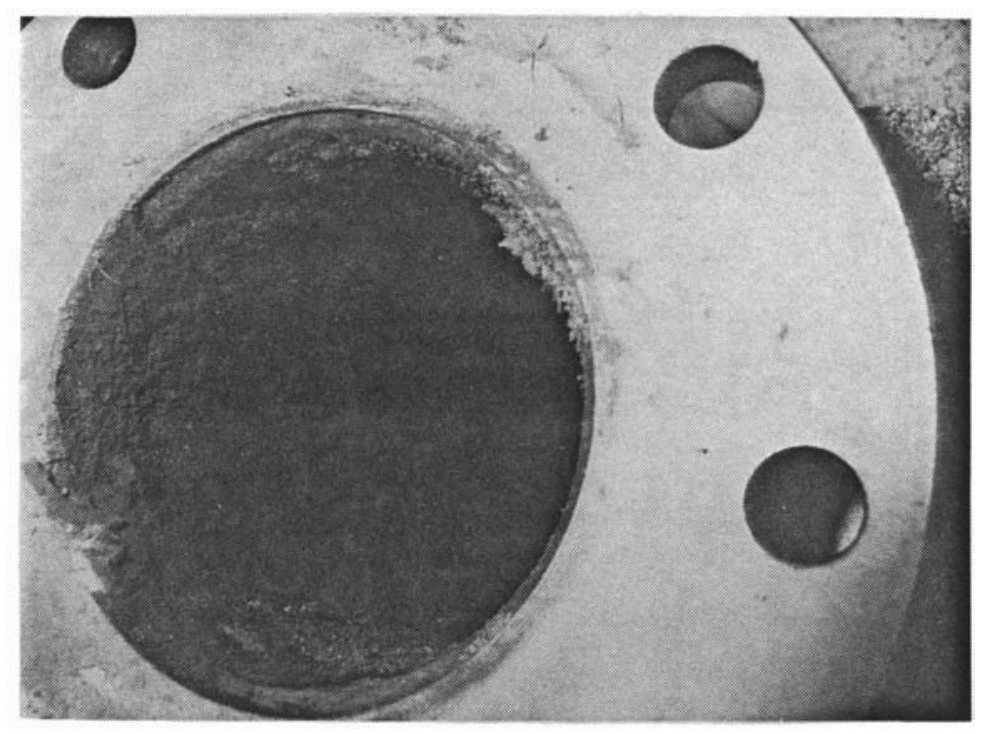

FIGURE A.41. PSCM-2 \#13

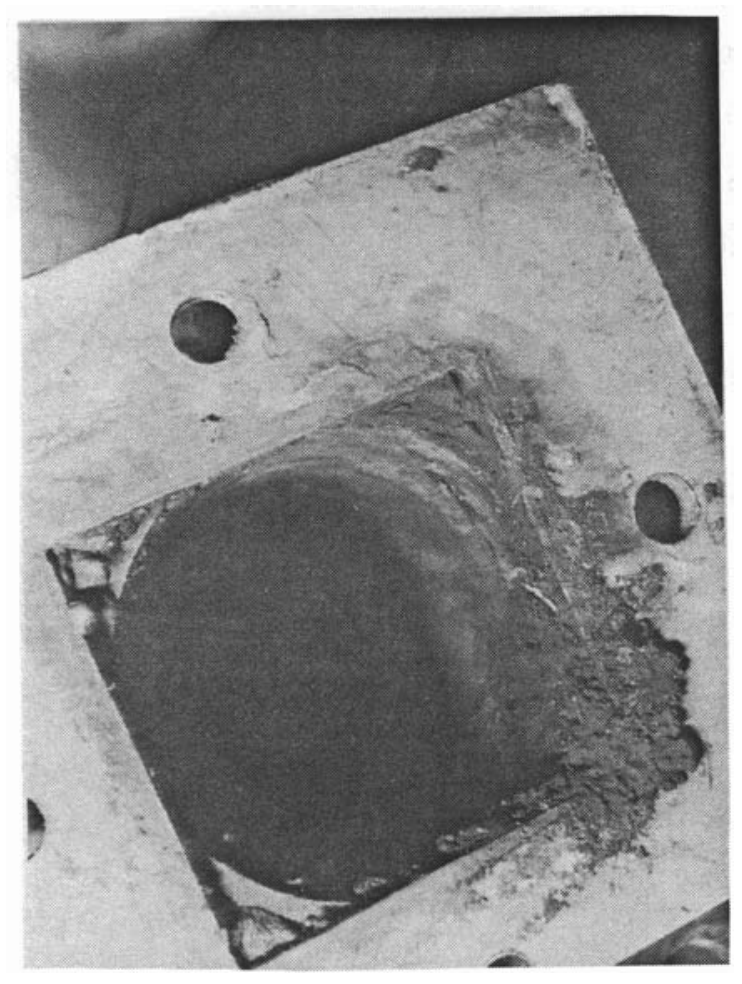

FIGURE A.42. PSCM-2 \#14 
TABLE A.13. PSCM-2 Pipe Deposits

\begin{tabular}{|c|c|c|c|c|c|}
\hline \multirow[b]{2}{*}{$\begin{array}{l}\text { Elemental } \\
\text { Oxides }\end{array}$} & \multicolumn{5}{|c|}{ Weight Percent } \\
\hline & "Y" & $\begin{array}{l}\text { Flex } \\
\text { Hose } \\
\end{array}$ & $\begin{array}{c}\text { Inside } \\
\text { Lid } \\
\end{array}$ & $\begin{array}{c}\text { Corrosion } \\
\text { Test } \\
\end{array}$ & $\begin{array}{r}90^{\circ} \\
\text { El bon }\end{array}$ \\
\hline $\mathrm{Al}_{23}$ & 1.8 & 1.5 & 1.5 & 1.6 & 1.2 \\
\hline $\mathrm{B}_{2} \mathrm{O}_{3}$ & 4.0 & 3.7 & 1.6 & 5.0 & 3.1 \\
\hline $\mathrm{CaO}$ & 4.8 & 3.6 & 3.5 & 3.7 & 3.6 \\
\hline $\mathrm{CdO}$ & 0.04 & 0.10 & 0.02 & 0.08 & 0.10 \\
\hline $\mathrm{Cl}^{-}$ & 6.63 & 10.7 & 19.8 & 9.56 & 22.9 \\
\hline $\mathrm{Cs}_{2} \mathrm{O}$ & $0.3 b$ & 1.34 & 0.44 & 1.0 & 1.22 \\
\hline $\mathrm{Cr}_{2} \mathrm{O}_{3}$ & 0.98 & 0.90 & 0.36 & 0.50 & 0.91 \\
\hline $\mathrm{F}^{-}$ & 0.096 & 0.05 & 0.13 & 0.097 & 0.15 \\
\hline $\mathrm{Fe}_{2} \mathrm{O}_{3}$ & 16.0 & 15.0 & 10.5 & 13.0 & 14.0 \\
\hline LiO & 3.0 & 2.6 & 2.8 & 3.0 & 2.6 \\
\hline $\mathrm{MgO}$ & 1.1 & 0.70 & 0.85 & 0.80 & 0.66 \\
\hline $\mathrm{MnO}_{2}$ & 3.9 & 3.4 & 3.3 & 3.6 & 4.2 \\
\hline $\mathrm{Na}_{2} \mathrm{O}$ & 13.0 & 16.6 & 23.0 & 17.0 & 21.0 \\
\hline $\mathrm{NiO}$ & 2.5 & 2.4 & 1.8 & 1.9 & 2.6 \\
\hline $\mathrm{RuO}_{2}$ & 0.10 & 0.35 & 0.11 & 0.22 & 0.26 \\
\hline $\mathrm{Sb}_{2} \mathrm{O}_{3}$ & $<0.04$ & -- & $<0.04$ & -- & -- \\
\hline $\mathrm{Se}$ & 0.097 & 0.11 & 0.006 & 0.13 & 0.28 \\
\hline $\mathrm{SiO}_{2}$ & 25.0 & 21.0 & 21.0 & 27.0 & 13.0 \\
\hline $\mathrm{SO}_{4}=$ & 3.03 & 9.45 & 6.02 & 3.89 & 5.79 \\
\hline Sro & 0.038 & 0.03 & 0.03 & 0.03 & 0.03 \\
\hline $\mathrm{TeO}_{2}$ & 0.06 & 0.10 & 0.07 & 0.08 & 0.08 \\
\hline $\mathrm{TiO}_{2}$ & 0.46 & 0.38 & 0.38 & 0.50 & 0.25 \\
\hline Zno & 0.025 & 0.025 & 0.02 & 0.02 & 0.05 \\
\hline $\mathrm{ZrO}_{2}$ & 0.23 & 0.16 & 0.20 & 0.22 & 0.13 \\
\hline
\end{tabular}


TABLE A.14. Compositional Comparison of Off-Gas-Line Deposits

\begin{tabular}{|c|c|c|c|c|}
\hline \multirow{2}{*}{$\begin{array}{l}\text { Elemental } \\
\text { Oxides } \\
\end{array}$} & \multicolumn{4}{|c|}{ Weight Percent } \\
\hline & $\overline{\mathrm{PSCM}-2}$ & LFCM-4 & PSCM-1 & LFCM-2 \\
\hline $\mathrm{Al}_{2}{ }_{2} \mathrm{O}_{3}$ & 1.6 & 2.0 & -- & 1.7 \\
\hline $\mathrm{B}_{2} \mathrm{O}_{3}$ & 3.4 & 5.6 & 4.6 & 4.6 \\
\hline $\mathrm{CaO}$ & 4.1 & 6.5 & -- & 4.4 \\
\hline $\mathrm{CdO}$ & 0.05 & 0.08 & -- & -- \\
\hline $\mathrm{Cr}_{2} \mathrm{O}_{3}$ & 0.78 & 0.31 & -- & -- \\
\hline $\mathrm{Cs}_{2} \mathrm{O}$ & 0.11 & 0.31 & 0.80 & 0.26 \\
\hline $\mathrm{Fe}_{2} \mathrm{O}_{3}$ & 14.2 & 14.0 & 10.0 & 20.0 \\
\hline LiO & 2.9 & 3.4 & -- & 2.0 \\
\hline $\mathrm{MgO}$ & 0.92 & 2.5 & -- & 0.22 \\
\hline $\mathrm{MnO}_{2}$ & 3.6 & 3.4 & -- & 1.2 \\
\hline $\mathrm{Na}_{2} \mathrm{O}$ & 16.8 & 15.0 & 20.0 & 17.0 \\
\hline $\mathrm{NiO}$ & 2.3 & -- & -- & 2.5 \\
\hline $\mathrm{RuO}_{2}$ & 0.17 & 0.16 & -- & 0.3 \\
\hline $\mathrm{Sb}_{2} \mathrm{O}_{3}$ & $<0.04$ & -- & -- & -- \\
\hline SiO & 22.7 & 31.0 & -- & 31.0 \\
\hline Sro & 0.03 & 0.05 & -- & 0.04 \\
\hline $\mathrm{TeO}_{2}$ & 0.07 & 0.11 & -- & 0.07 \\
\hline Ti0 & 0.42 & 0.11 & -- & 0.07 \\
\hline $\mathrm{ZrO}_{2}$ & 0.20 & 0.29 & -- & -- \\
\hline
\end{tabular}

emission rates. Of the previous melter runs, only LFCM-4, which itself utilized electric lid boosting to maximize feeding rates, exhibited a lower overall DF.

Since one of the primary objectives of the PSCM-2 test was to investigate the effects of propane combustion boosting upon melter feeding rates, the gas composition of the melter plenum was of particular engineering interest. Gas chromatographic analysis of the plenum gases was conducted throughout the PSCM-2 experiment. The results of these analyses are illustrated in Fiyure A.43. The relationship between the concentrations of $\mathrm{N}_{2}, \mathrm{O}_{2}$, and $\mathrm{CO}_{2}$ are consistent with the stoichiometry of total combustion of $\mathrm{C}_{3} \mathrm{H}_{8}$. That is, the 
TABLE A.15. PSCM-2 Decontamination Factors

\begin{tabular}{|c|c|c|c|c|c|}
\hline \multirow[b]{2}{*}{ Element } & \multirow{2}{*}{$\begin{array}{l}\text { PSCM-2 } \\
\text { Average } \\
\text { DF } \\
\end{array}$} & \multicolumn{4}{|c|}{ DF Ratio } \\
\hline & & $\begin{array}{l}\frac{\text { PSCM-2 }}{\text { LFCM-2 }} \\
\end{array}$ & $\begin{array}{l}\text { PSCM-2 } \\
\text { LFCM-3 }\end{array}$ & $\frac{\text { PSCM-2 }}{\text { PSCM-1 }}$ & $\frac{\text { PSCM-2 }}{\frac{\text { LFCM-4 }}{L}}$ \\
\hline Al & 990 & 0.20 & 0.41 & 0.090 & 1.9 \\
\hline B & 160 & 0.62 & 1.30 & 0.76 & 1.2 \\
\hline $\mathrm{Ca}$ & 610 & 0.82 & 0.33 & 0.33 & 2.3 \\
\hline $\mathrm{Cd}$ & 47 & 0.14 & 0.56 & 0.25 & 0.67 \\
\hline C1 & 3 & 0.17 & 0.33 & 0.96 & 1.4 \\
\hline Cs & 3 & 0.075 & 0.43 & 0.059 & 0.053 \\
\hline $\mathrm{Fe}$ & 680 & 1.60 & 0.99 & 0.18 & 2.6 \\
\hline Li & 340 & 0.37 & 0.52 & 0.18 & 1.1 \\
\hline $\mathrm{Mg}$ & 930 & 1.90 & 0.52 & 0.10 & 2.6 \\
\hline $\mathrm{Mn}$ & 630 & 0.40 & 0.20 & 0.11 & 1.5 \\
\hline $\mathrm{Na}$ & 130 & 0.39 & 0.46 & 0.16 & 0.38 \\
\hline $\mathrm{Ru}$ & 48 & 6.90 & 0.80 & 1.5 & 1.8 \\
\hline$S$ & 19 & $>1.0$ & 3.8 & 19.0 & 19.0 \\
\hline $\mathrm{Sb}$ & 100 & 0.21 & -- & -- & 0.056 \\
\hline $\mathrm{Si}$ & 1600 & 1.70 & 0.61 & 0.11 & 3.8 \\
\hline $\mathrm{Sr}$ & 640 & 1.70 & 0.43 & 0.086 & 3.1 \\
\hline $\mathrm{Te}$ & 58 & 0.95 & 0.21 & 0.34 & 0.93 \\
\hline $\mathrm{Ti}$ & 1400 & 1.27 & -- & -- & -- \\
\hline TOTA & 430 & 0.76 & 0.89 & 0.38 & 1.5 \\
\hline
\end{tabular}

relative cnange in the percent composition of $\mathrm{O}_{2}, \mathrm{CO}_{2}$, and $\mathrm{N}_{2}$, as a function of oxidation rate, will vary as $-1: 2 / 3: 1 / 3$, respectively, if complete combustion is assumed.

LFCM-6 - JUNE 1981

LFCM-6 was a 120-h experirnent designed to characterize maximm feeding rates achievable utilizing both electric lid heaters and plasma torch boosting techniques. To minimize off-gas line deposition, a spray nozzle was used to introduce mechanically atomized water countercurrent to the exhaust flow at the 


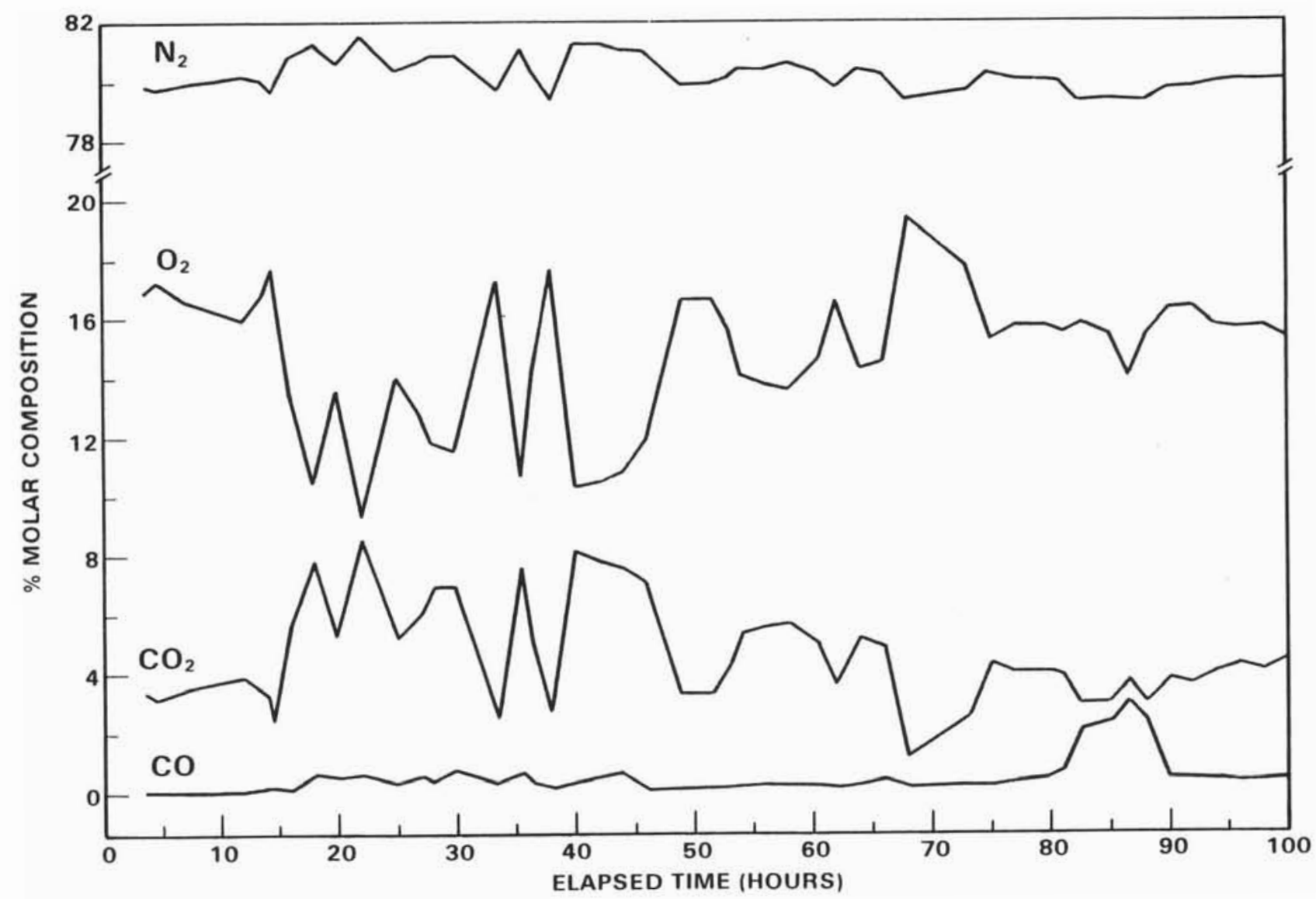

FIGURE A.43. PSCM-2 Plenum Off-Gas Composition 
entrance of the melter off-gas exhaust line. The locations of the off-gas line components are illustrated in Figure A.44. The deposits that did form in the melter off-gas line components are illustrated in Figures A.45 through A.50.

It should be noted that the close-coupled vertical components had been cleaned $24 \mathrm{~h}$ prior to the end of the run in order to evaluate frit blasting as an offgas cleaning technique. Nevertheless, the deposits that were removed by this technique were light and hairlike. The compositions of the deposits that formed in the various off-gas line components detailed in Figure A.44 are lis ted in Table A.16. A comparison of the weighted average composition of LFCM-6 line deposits with off-gas line deposits formed in previous melter experiments is detailed in Table A.17. Again, the similarities of these deposits are more striking than their minor differences. The semivolatiles $\mathrm{Cs}, \mathrm{Ru}$, $\mathrm{Sb}$ and Te, which are minor feed components but major radiological hazards, are enriched in these deposits.

Total feed component DFs for the LFCM-6 test are summarized in Table A.18. Efforts to establish a greater trace element homogeneity in the

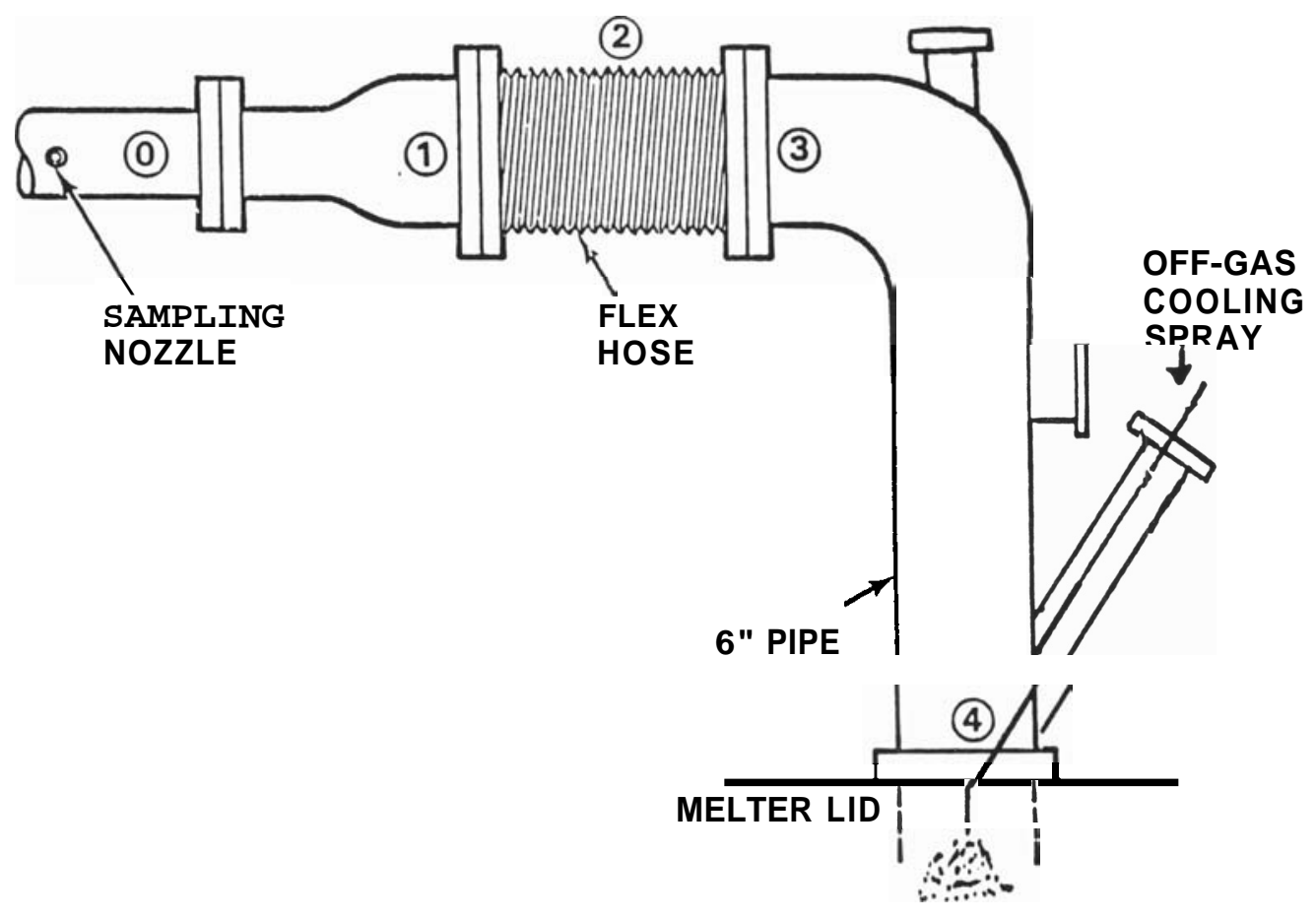

FIGURE A.44. LFCM-6 Off-Gas Line Configuration 


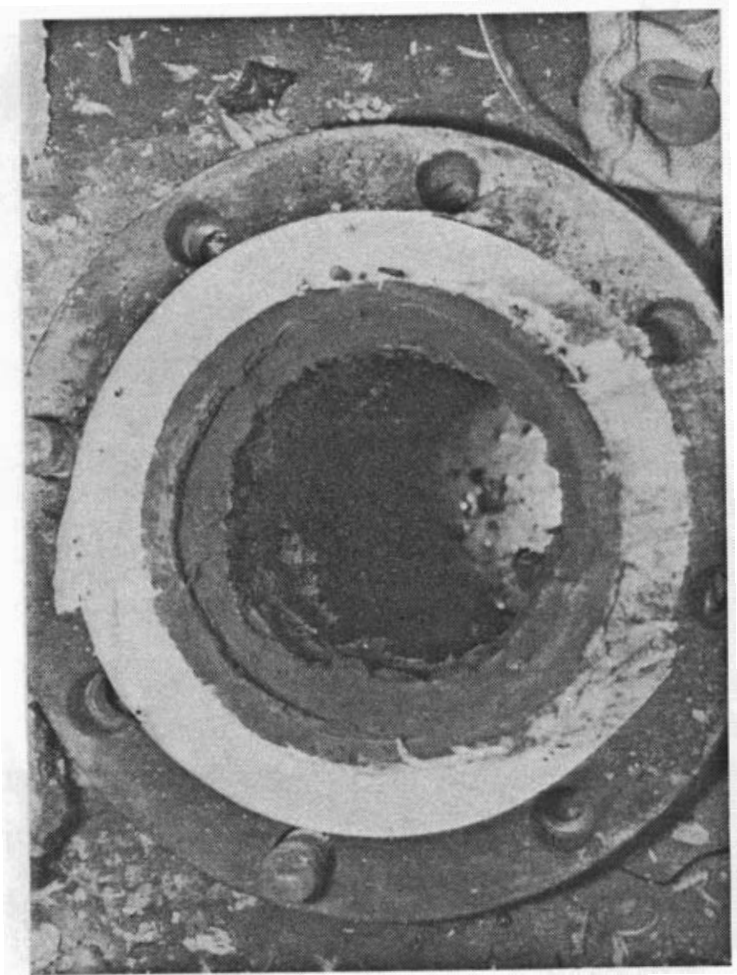

FIGURE A.45. LFCM-6 Melter Lid

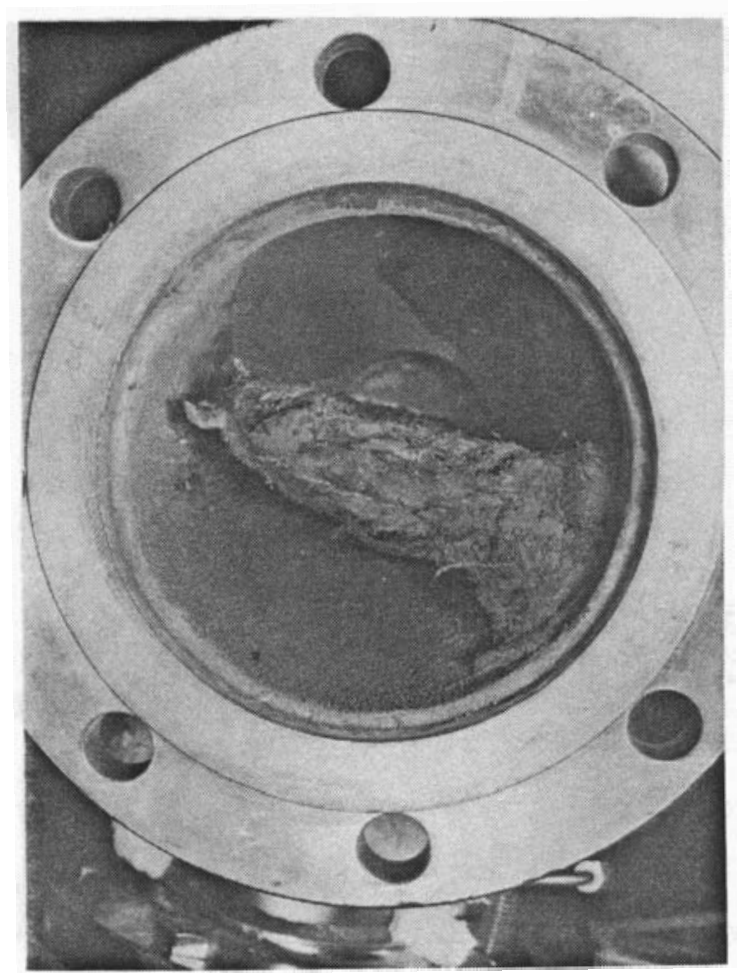

FIGURE A.47. LFCM-6 \# 3

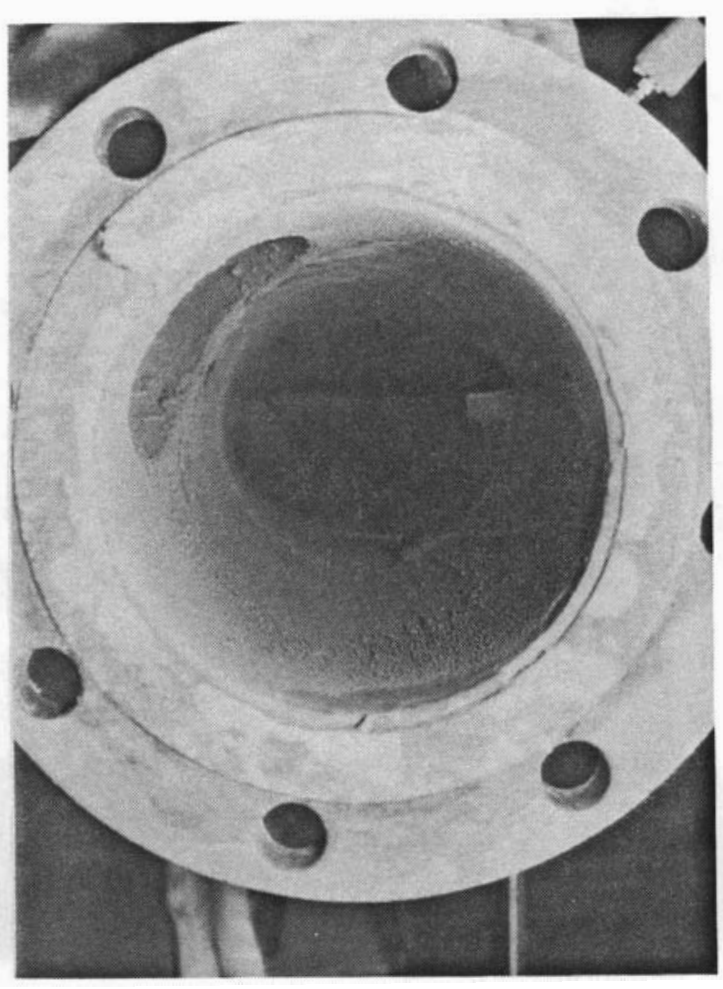

FIGURE A.46. LFCM-6 \#4

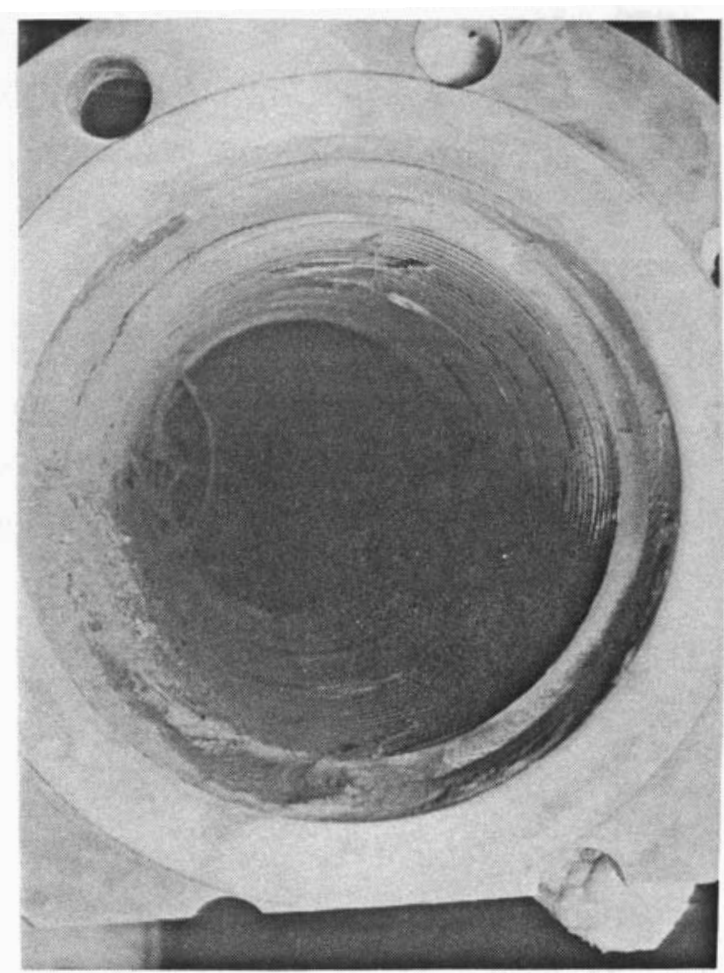

FIGURE A.48. LFCM-6 \#2 


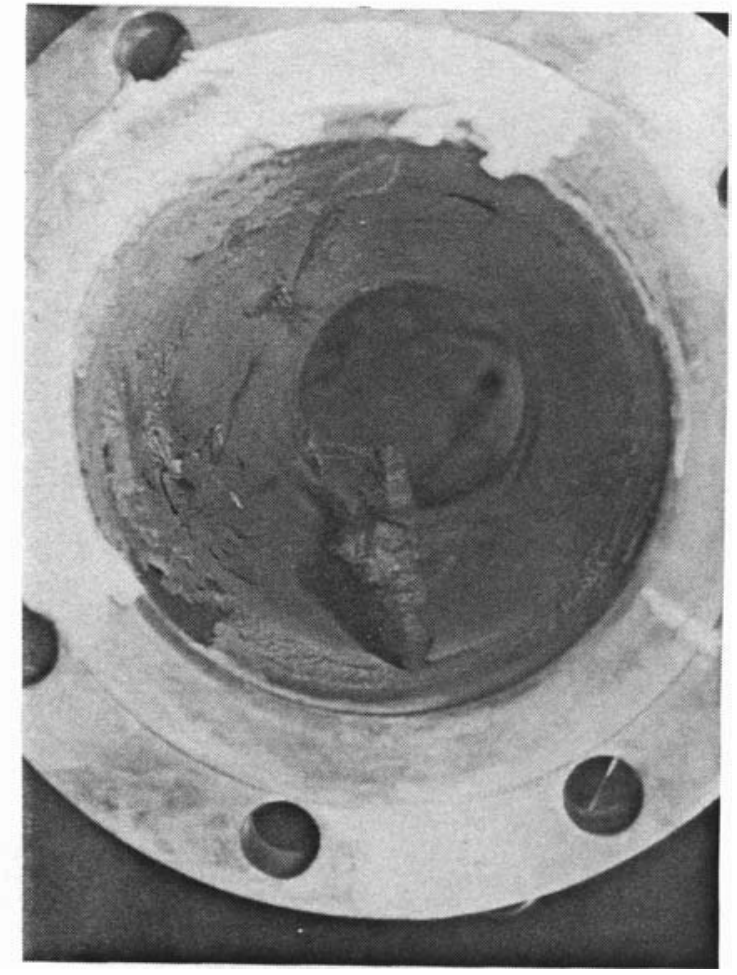

FIGURE A.49. $\quad$ LFCM-6 \#1

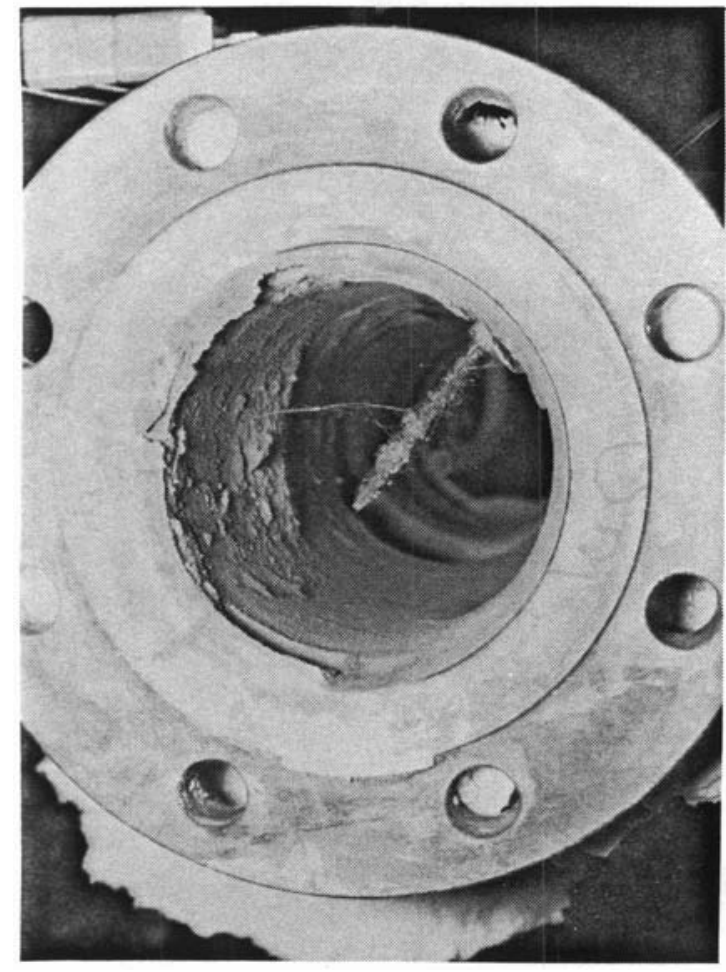

FIGURE A.50. $\quad$ LFCM-6 \#0

feed makeup tanks appear to have produced much more consistent results between sampling runs than have been achieved in previous experiments. Also presented in this table is the total particulate DF as determined by absolute HEPA filtration. The agreement between these two sets of independent data is quite satisfying. Table A.19 compares the average LFCM-6 feed component DFs with those obtained from previous melter runs. Clearly, the LFCM-6 test exhibited the highest effective effluent emission rates of all liquid-fed melter runs conducted to date. Erratic, non-steady-state running conditions associated with this test are, no doubt, responsible for this result.

The use of plasma torches within an operating melter presents a potentially explosive hazard due to hydrogen generation resulting from plasmainitiated decomposition of $\mathrm{H}_{2} \mathrm{O}$. Tests of the plasma torches before LFCM-6 using building steam revealed that significant quantities of hydrogen $(-4.5 \%$ dry basis) could be generated by this torch when low inleakage rates existed. Consequently, monitoring the noncondensible composition of the melter exhaust was of particular interest during this experiment. The results of these 
TABLE A.16. $\quad$ LFCM-6 Off-Gas-Line Deposits

\begin{tabular}{|c|c|c|c|c|c|c|}
\hline \multirow{2}{*}{$\begin{array}{l}\text { Elemental } \\
\text { Oxides }\end{array}$} & \multicolumn{6}{|c|}{ Weight Percent } \\
\hline & $\# 1$ & $\begin{array}{l}\text { Samplt } \\
\# 2\end{array}$ & $\frac{\text { Number }}{\# 3}$ & $\# 4$ & Average & Feed \\
\hline $\mathrm{Al}_{2} \mathrm{O}_{2}$ & 1.6 & 19 & 1.8 & 2,1 & 19 & 3.5 \\
\hline H 23 & 1.0 & 100 & 1.0 & 2.1 & 1.0 & 0 \\
\hline $\mathrm{B}_{2} \mathrm{O}_{3}$ & 7.0 & 8.0 & 7.1 & 6.8 & 7.2 & 9.9 \\
\hline $\mathrm{CaO}$ & 0.73 & 0.91 & 0.83 & 0.73 & 0.80 & 1.2 \\
\hline $\mathrm{CdO}$ & 0.23 & 0.23 & 0.21 & 0.21 & 0.22 & 0.01 \\
\hline $\mathrm{Cr}_{2} \mathrm{O}_{3}$ & 0.16 & 0.13 & 0.08 & 0.09 & 0.10 & 0.02 \\
\hline $\mathrm{Cs}_{2} \mathrm{O}$ & 0.21 & 0.16 & 0.20 & 0.20 & 0.19 & 0.06 \\
\hline $\mathrm{Fe}_{2} \mathrm{O}_{3}$ & 13.7 & 12.3 & 12.0 & 11.0 & 12.0 & 16.0 \\
\hline $\mathrm{La}_{2} \mathrm{O}_{3}$ & 0.20 & 0.23 & 0.22 & 0.22 & 0.22 & -- \\
\hline LiO & 3.0 & 3.2 & 3.0 & 3.2 & 3.1 & 4.1 \\
\hline $\mathrm{MgO}$ & 0.81 & 0.95 & 0.93 & 0.93 & 0.90 & 1.4 \\
\hline $\mathrm{MnO}_{2}$ & 1.6 & 2.4 & 2.4 & 2.4 & 2.2 & 3.8 \\
\hline $\mathrm{Na}_{2} \mathrm{O}$ & 15.0 & 13.0 & 13.0 & 13.0 & 13.0 & 15.5 \\
\hline NiO & -- & -- & -- & -- & -- & 1.5 \\
\hline $\mathrm{RuO}_{2}$ & 0.49 & 0.36 & 0.57 & 0.44 & 0.47 & 0.02 \\
\hline $\mathrm{Sb}_{2} \mathrm{O}_{3}$ & -- & 0.03 & 0.03 & 0.04 & 0.03 & 0.008 \\
\hline $\mathrm{SiO}_{2}$ & 30.0 & 34.0 & 32.0 & 32.0 & 32.0 & 44.0 \\
\hline Sro & 0.02 & 0.03 & 0.02 & 0.02 & 0.02 & 0.02 \\
\hline $\mathrm{TeO}_{2}$ & 0.06 & 0.05 & 0.05 & 0.06 & 0.06 & 0.01 \\
\hline $\mathrm{TiO}$ & 0.78 & 0.88 & 0.62 & 0.61 & 0.72 & 0.70 \\
\hline $\mathrm{ZrO}_{2}$ & 0.22 & 0.29 & 0.29 & 0.28 & 0.27 & -- \\
\hline
\end{tabular}

analyses are presented in Table A.20. Because of the large melter inleakage rates, hydrogen was not detectable $\left(\mathrm{H}_{2}<0.1 \%\right)$ during the LFCM-6 test. Indeed, the inleakayes were high enough that the plasma torch support gas (Ar) had only a minimal effect upon the noncondensible off-gas composition. Argon and oxygen concentrations are combined in this table since they are not resolvable under the running conditions of the GC used in these analyses. 


\section{TABLE A.17. Melter Pipe Deposition Composition}

\begin{tabular}{|c|c|c|c|c|c|}
\hline \multirow{2}{*}{$\begin{array}{l}\text { Elemental } \\
\text { Oxides }\end{array}$} & \multicolumn{5}{|c|}{ Weight Percent } \\
\hline & LFCM-6 & PSCM-2 & LFCM-4 & PSCM-1 & LFCM-2 \\
\hline $\mathrm{Al}_{2} \mathrm{O}_{3}$ & 1.9 & 1.6 & 2.0 & -- & 1.7 \\
\hline $\mathrm{B}_{2} \mathrm{O}_{3}$ & 7.2 & 3.4 & 5.6 & 4.6 & 4.6 \\
\hline $\mathrm{CaO}$ & 0.80 & 4.1 & 6.5 & -- & 4.4 \\
\hline $\mathrm{CdO}$ & 0.22 & 0.05 & 0.08 & -- & -- \\
\hline $\mathrm{Cs}_{2} \mathrm{O}$ & 0.19 & 0.11 & 0.31 & 0.80 & 0.26 \\
\hline $\mathrm{Cr}_{2} \mathrm{O}_{3}$ & 0.10 & 0.78 & 0.31 & -- & -- \\
\hline $\mathrm{Fe}_{2} \mathrm{O}_{3}$ & 12.0 & 14.2 & 14.0 & 10.0 & 20.0 \\
\hline Li0 & 3.1 & 2.9 & 3.4 & -- & 2.0 \\
\hline MgO & 0.90 & 0.92 & 2.5 & -- & 0.22 \\
\hline $\mathrm{MnO}_{2}$ & 2.2 & 3.6 & 3.4 & -- & 1.2 \\
\hline $\mathrm{Na}_{2} \mathrm{O}$ & 13.0 & 16.8 & 15.0 & 20.0 & 17.0 \\
\hline $\mathrm{NiO}$ & -- & 2.3 & -- & -- & 2.5 \\
\hline $\mathrm{RuO}_{2}$ & 0.47 & 0.17 & 0.16 & -- & 0.3 \\
\hline $\mathrm{Sb}_{2} \mathrm{O}_{3}$ & 0.03 & $<0.04$ & -- & -- & -- \\
\hline SiO & 32.0 & 22.7 & 31.0 & -- & 31.0 \\
\hline Sro & 0.02 & 0.03 & 0.05 & -- & 0.04 \\
\hline $\mathrm{TeO}_{2}$ & 0.06 & 0.07 & 0.11 & -- & 0.07 \\
\hline TiO & 0.72 & 0.42 & 0.11 & -- & 0.07 \\
\hline $\mathrm{ZrO}_{2}$ & 0.27 & 0.20 & 0.29 & -- & -- \\
\hline
\end{tabular}

PSCM-3 - JULY 1981

The PSCM-3 experiment was the first large-scale test of a liquid-fed ceramic melter with a formate-based feed composition. Since the primary objective of this experiment was to assess the response of liquid-fed melters and supporting equipment with this new feed formulation, no feed-boosting techniques were employed during this test. Consequently, this experiment was very much like that of the PSCM-1 test, except for the feed composition. A comparison of al1 pertinent operating parameters associated with these PSCM experiments appears in Table 1. The location of the PSCM-3 off-gas exhaust line components are detailed in Figure A.51. 
TABLE A.18. LFCM-6 Decontamination Factors

\begin{tabular}{|c|c|c|c|c|}
\hline \multirow[b]{2}{*}{$\begin{array}{c}\text { Elernental } \\
\text { Oxides }\end{array}$} & \multicolumn{3}{|c|}{ Experimental DFs } & \multirow[b]{2}{*}{$\begin{array}{c}\text { Average } \\
\text { DF }\end{array}$} \\
\hline & $\overline{\# 1}$ & $\frac{27 \mathrm{ple}}{\# 2}$ & $\# 3$ & \\
\hline A1 & 272 & 342 & 390 & 330 \\
\hline B & 89 & 95 & 90 & 90 \\
\hline $\mathrm{Ca}$ & 230 & 180 & 140 & 180 \\
\hline $\mathrm{Cd}$ & 85 & 84 & 82 & 80 \\
\hline $\mathrm{C} 1$ & 3 & 2 & 2 & 2 \\
\hline Cs & 4 & 11 & 13 & 10 \\
\hline $\mathrm{Fe}$ & 210 & 230 & 230 & 230 \\
\hline La & 250 & 280 & 300 & 280 \\
\hline $\mathrm{Li}$ & 150 & 160 & 170 & 160 \\
\hline $\mathrm{Mg}$ & 237 & 273 & 276 & 260 \\
\hline $\mathrm{Mn}$ & 210 & 330 & 400 & 330 \\
\hline $\mathrm{Na}$ & 89 & 83 & 95 & 90 \\
\hline $\mathrm{Ni}$ & 710 & 990 & 1100 & 930 \\
\hline Ru & 10 & 22 & 9 & 13 \\
\hline $\mathrm{s}$ & 10 & 8 & 16 & 11 \\
\hline $\mathrm{Sb}$ & $>60$ & $>100$ & $>70$ & -- \\
\hline Si & 284 & 260 & 290 & 280 \\
\hline $\mathrm{Sr}$ & 290 & 300 & 270 & 290 \\
\hline $\mathrm{Te}$ & 190 & 230 & 214 & 210 \\
\hline $\mathrm{Ti}$ & 96 & 120 & 300 & 170 \\
\hline $\mathrm{Zr}$ & 260 & 245 & 270 & 260 \\
\hline TOTAL & 160 & 170 & 180 & 170 \\
\hline
\end{tabular}

The extent of feed component deposition occurring within these off-gas exhaust lines is graphically displayed in Figures A.52 through A.62. Qualitatively, the depositions illustrated in these figures sugyest that PSCM-3 produced hiyher overall emission rates than PSCM-1. Again, the only significant difference between these two PSCM experiments was the nature of the feed. 
TABLE A.19. LFCM-6 Comparative DFs

\begin{tabular}{|c|c|c|c|c|c|c|}
\hline \multirow[b]{2}{*}{$\begin{array}{l}\text { Elemental } \\
\text { Oxides }\end{array}$} & \multirow{2}{*}{$\begin{array}{l}\text { LFCM-6 } \\
\text { Average } \\
\text { DF } \\
\end{array}$} & \multicolumn{5}{|c|}{ DF Ratio } \\
\hline & & $\begin{array}{l}\text { LFCM-6 } \\
\text { LFCM-2 }\end{array}$ & $\begin{array}{l}\text { LFCM-6 } \\
\text { LFCM-3 }\end{array}$ & $\begin{array}{l}\text { LFCM-6 } \\
\text { PSCM-1 } \\
\end{array}$ & $\begin{array}{l}\text { LFCM-6 } \\
\text { LFCM-4 }\end{array}$ & $\begin{array}{l}\text { LFCM-6 } \\
\text { PSCM-2 }\end{array}$ \\
\hline$A 1$ & 330 & 0.067 & 0.14 & 0.030 & 0.62 & 0.33 \\
\hline B & 90 & 0.35 & 0.74 & 0.43 & 0.69 & 0.56 \\
\hline $\mathrm{Ca}$ & 180 & 0.24 & 0.097 & 0.099 & 0.69 & 0.30 \\
\hline $\mathrm{Cd}$ & 80 & $>0.23$ & 0.95 & 0.42 & 1.1 & 1.7 \\
\hline $\mathrm{Cl}$ & 2 & 0.11 & 0.22 & 0.64 & 0.93 & 0.67 \\
\hline Cs & 10 & 0.25 & 1.4 & 0.20 & 0.17 & 3.3 \\
\hline $\mathrm{Fe}$ & 230 & 0.55 & 0.33 & 0.060 & 0.88 & 0.34 \\
\hline Li & 160 & 0.17 & 0.24 & 0.084 & 0.52 & 0.47 \\
\hline $\mathrm{Mg}$ & 260 & 0.53 & 0.14 & 0.028 & 0.74 & 0.28 \\
\hline $\mathrm{Mn}$ & 330 & 0.21 & 0.11 & 0.58 & 0.79 & 0.52 \\
\hline $\mathrm{Na}$ & 90 & 0.27 & 0.32 & 0.11 & 0.26 & 0.69 \\
\hline $\mathrm{Ni}$ & 930 & 2.2 & 2.2 & 0.62 & 3.6 & -- \\
\hline $\mathrm{Ru}$ & 13 & 1.8 & 0.22 & 0.41 & 0.50 & 0.27 \\
\hline$S$ & 11 & -- & 2.2 & 11.0 & 11.0 & 0.58 \\
\hline Si & 280 & 0.30 & 0.11 & 0.019 & 0.67 & 0.18 \\
\hline $\mathrm{Sr}$ & 290 & 0.77 & 0.19 & 0.039 & 1.4 & 0.45 \\
\hline $\mathrm{Te}$ & 210 & 3.4 & 0.78 & 1.2 & 3.4 & 3.6 \\
\hline $\mathrm{Ti}$ & $\underline{170}$ & $\underline{0.15}$ & $=-$ & - & - & $\underline{0.12}$ \\
\hline TOTAL OXIUE & 170 & 0.30 & 0.35 & 0.15 & 0.59 & 0.40 \\
\hline
\end{tabular}

Deposits were collected from various components of the off-gas line components illustrated in the previously discussed figures in order to establish their elemental composition. This compositional data appears in Table A.21. The average coniposition of these deposits is, not surprisingly, very much like those exhibited by deposits formed in previous rnelter tests using a neutralized feed as is shown in Table A.22.

Total melter feed component DFs associated with PSCM-3 have been established for most elemental constituents. These data appear in Table A.23. Overall, these results are strikingly similar to the data generated by the original pilot-scale melter experiment, PSCM-1. A comparison of PSCM-3 DFs 
TABLE A.20. LFCM-6 Noncondensible Off-Gas Composition

\begin{tabular}{|c|c|c|c|c|c|c|}
\hline Date & Time & $\mathrm{CO}_{2}$ & {$\left[0_{2}+A r\right]$} & $\mathrm{N}_{2}$ & $\mathrm{CO}$ & Comments \\
\hline $5 / 31$ & $22: 06$ & 0.19 & 20.4 & 78.4 & -- & \\
\hline $5 / 31$ & $23: 15$ & 0.36 & 20.3 & 78.4 & -- & \\
\hline $6 / 01$ & $17: 01$ & 0.81 & 19.8 & 78.5 & 0.026 & \\
\hline $6 / 01$ & $18: 19$ & 0.67 & 19.7 & 78.7 & 0.038 & \\
\hline $6 / 01$ & $19: 41$ & 0.64 & 19.8 & 78.6 & 0.015 & \\
\hline $6 / 01$ & $21: 28$ & 0.62 & 19.9 & 78.6 & 0.015 & \\
\hline $6 / 01$ & $22: 39$ & 0.72 & 20.0 & 78.3 & 0.035 & \\
\hline $6 / 02$ & $00: 10$ & 0.51 & 20.1 & 78.4 & 0.050 & \\
\hline $6 / 02$ & $18: 09$ & 0.74 & 19.6 & 78.7 & -- & No Feed \\
\hline $6 / 02$ & $21: 56$ & 0.86 & 20.5 & 77.7 & 0.014 & \\
\hline $6 / 02$ & $22: 35$ & 0.13 & 20.7 & 78.2 & -- & No Feed \\
\hline $6 / 03$ & $15: 52$ & 0.52 & 19.9 & 78.6 & 0.067 & \\
\hline $6 / 03$ & $17: 31$ & 0.49 & 19.5 & 79.0 & 0.025 & \\
\hline $6 / 03$ & $18: 30$ & 0.43 & 19.5 & 79.1 & 0.021 & \\
\hline $6 / 03$ & $19: 19$ & 0.48 & 20.0 & 78.5 & 0.050 & \\
\hline $6 / 03$ & $20: 16$ & 0.66 & 19.8 & 78.6 & $>0.01$ & \\
\hline $6 / 03$ & $20: 55$ & 0.48 & 19.9 & 78.6 & $>0.01$ & \\
\hline $6 / 03$ & $21: 43$ & 0.55 & 19.9 & 78.6 & 0.015 & \\
\hline $6 / 03$ & $22: 28$ & 0.51 & 20.0 & 78.5 & 0.032 & \\
\hline $6 / 03$ & $23: 15$ & 0.42 & 19.9 & 78.8 & 0.035 & \\
\hline $6 / 04$ & $18: 19$ & 0.27 & 21.0 & 77.7 & 0.018 & Plasma Torch On \\
\hline $6 / 04$ & $19: 44$ & 0.39 & 22.1 & 76.6 & 0.020 & Plasma Torch On \\
\hline $6 / 04$ & $20: 47$ & 0.58 & 21.9 & 76.6 & 0.017 & Plasma Torch On \\
\hline $6 / 04$ & $22: 19$ & 0.43 & 22.7 & 76.0 & 0.024 & Plasma Torch On \\
\hline $6 / 04$ & $23: 18$ & 0.48 & 22.8 & 75.8 & 0.017 & Plasma Torch On \\
\hline
\end{tabular}




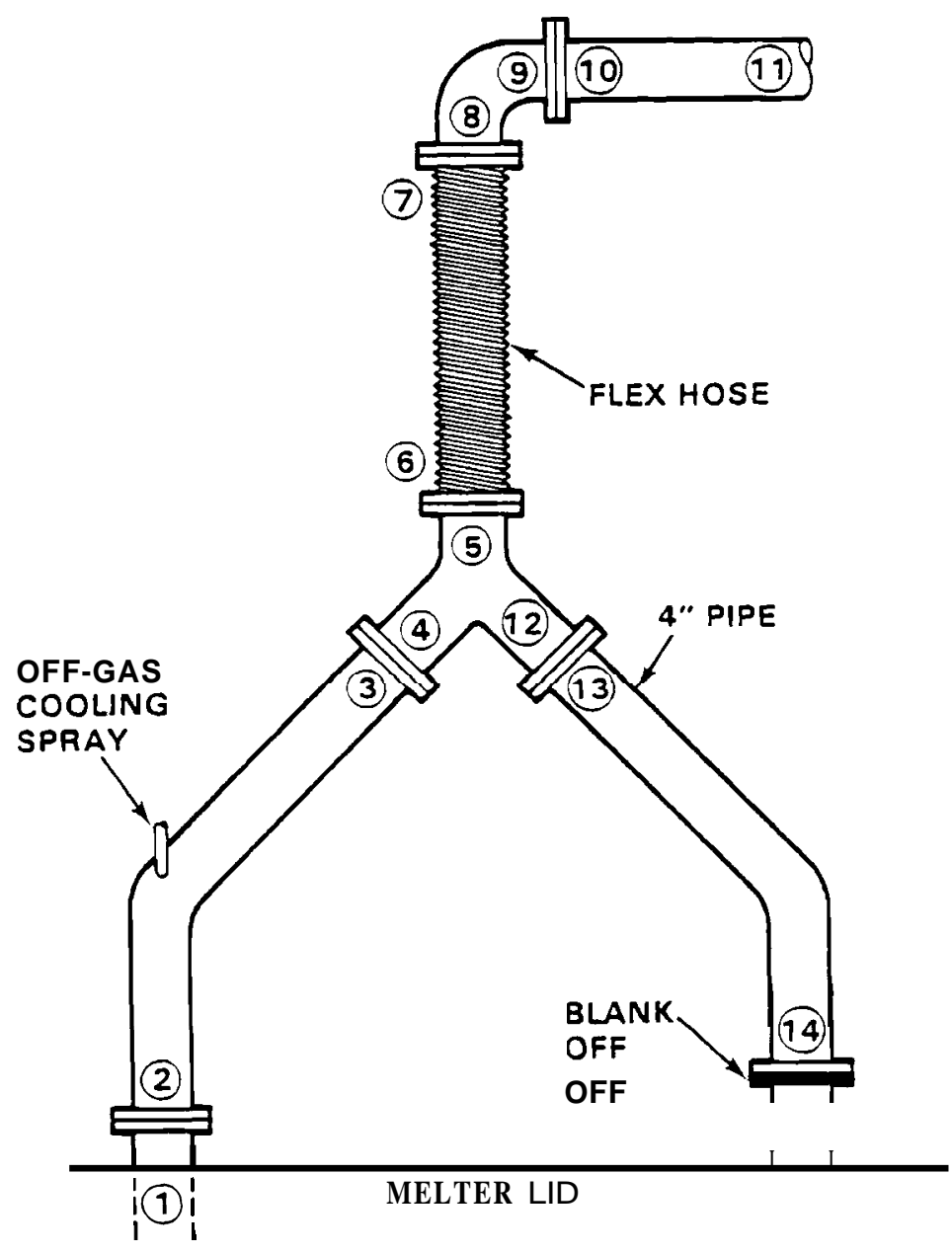

FIGURE A.51. PSCM-3 Off-Gas-Line Confiyuration

with DFs from all previous melter experiments covered in this report is presented in Table A.24. The effluent emission rates for PSCM-3 are lower than those exhibited by all other melter tests except PSCM-1. The low Cs DF associated with present data may not be an accurate measure of melter performance with reyard to this element. The Cs composition of PSCM-3 feed was exceedingly low. Un the other hand, the bulk glass within the melter possessed significant quantities of Cs from previous melter runs. Consequently, steady-state runniny conditions were never established for Cs duriny PSCM-3. The DF values for Ru and $\mathrm{Sb}$ are not available from this experiment. 


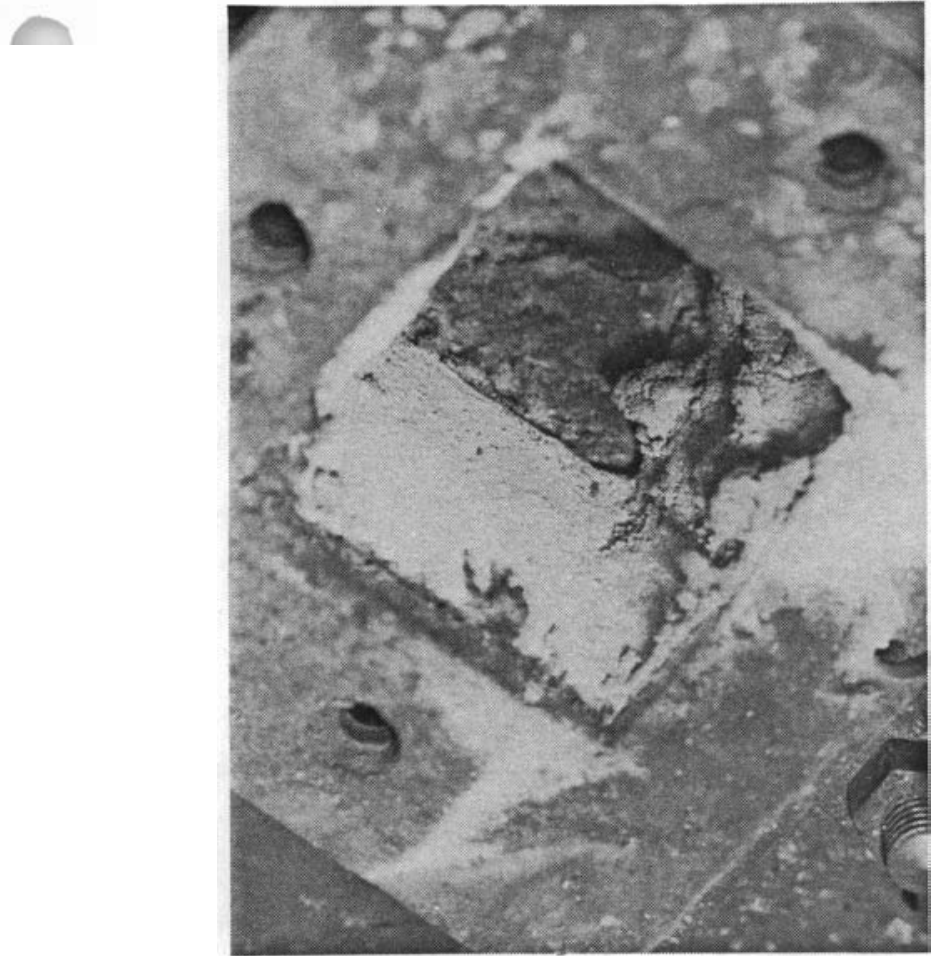

FIGURE A.52. PSCM-3 \#1

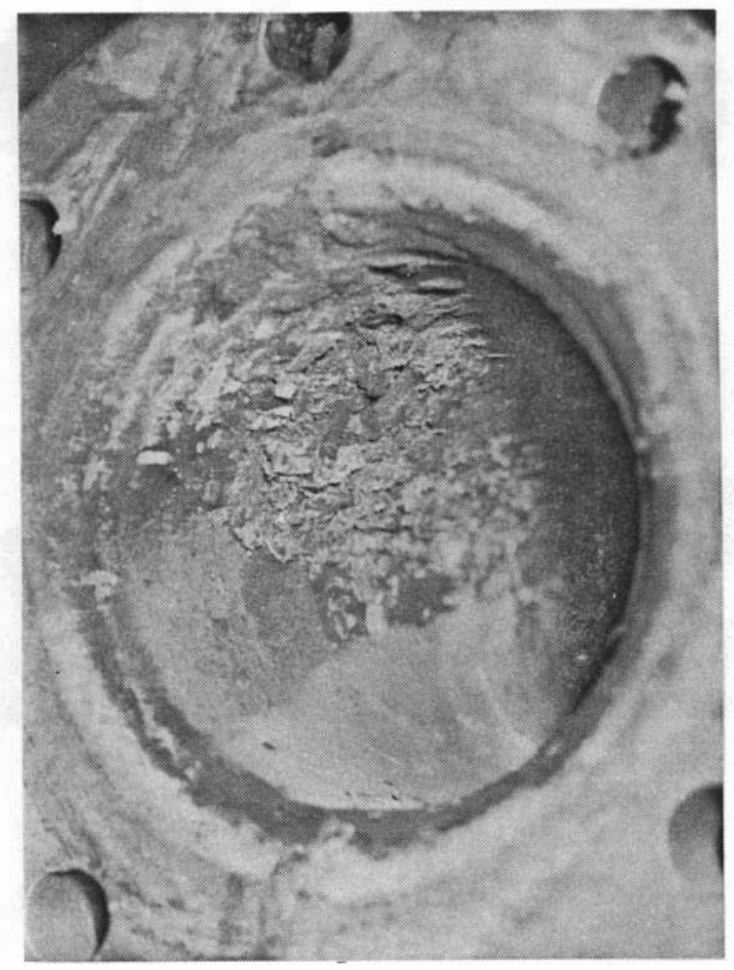

FIGURE A.54. PSCM-3 \#3

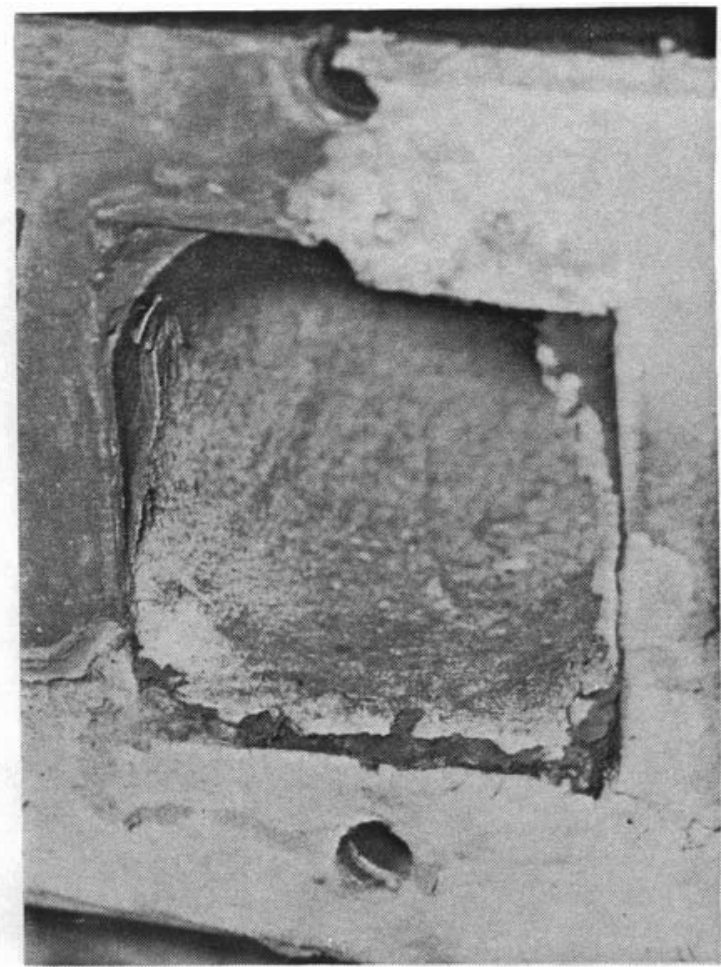

FIGURE A.53. PSCM-3 \#2

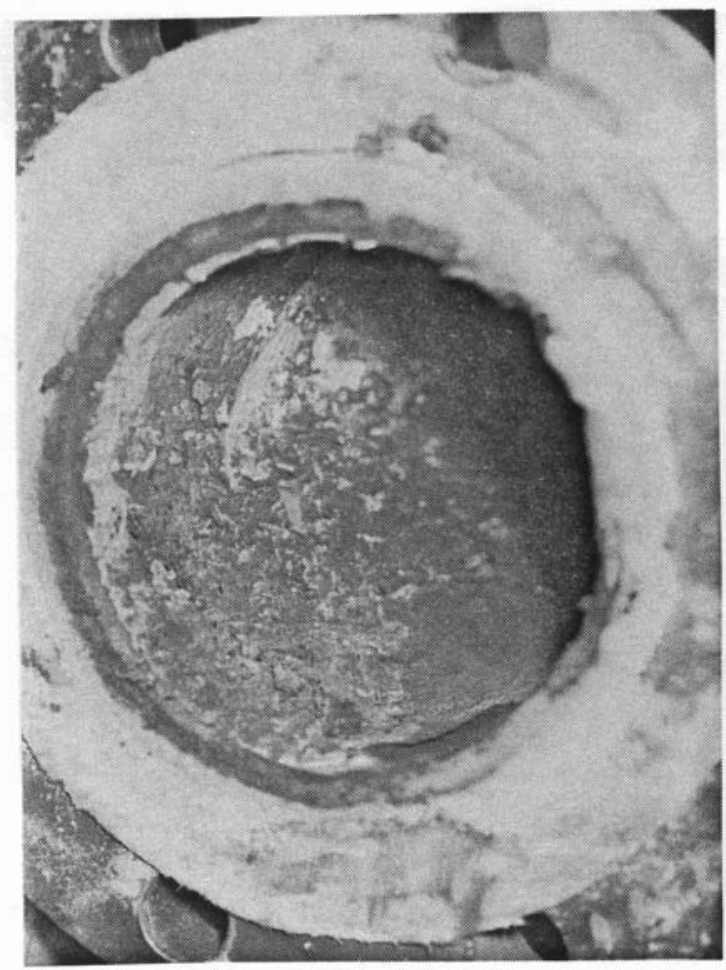

FIGURE A.55. PSCM-3 \#4 


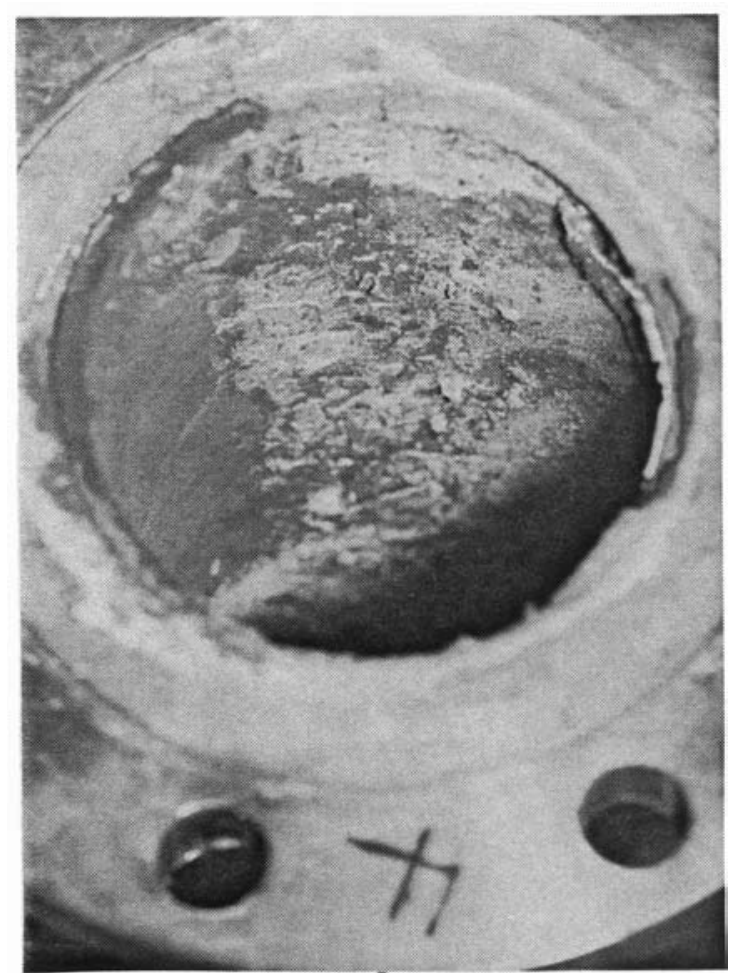

FIGURE A.56. PSCM-3 \#5

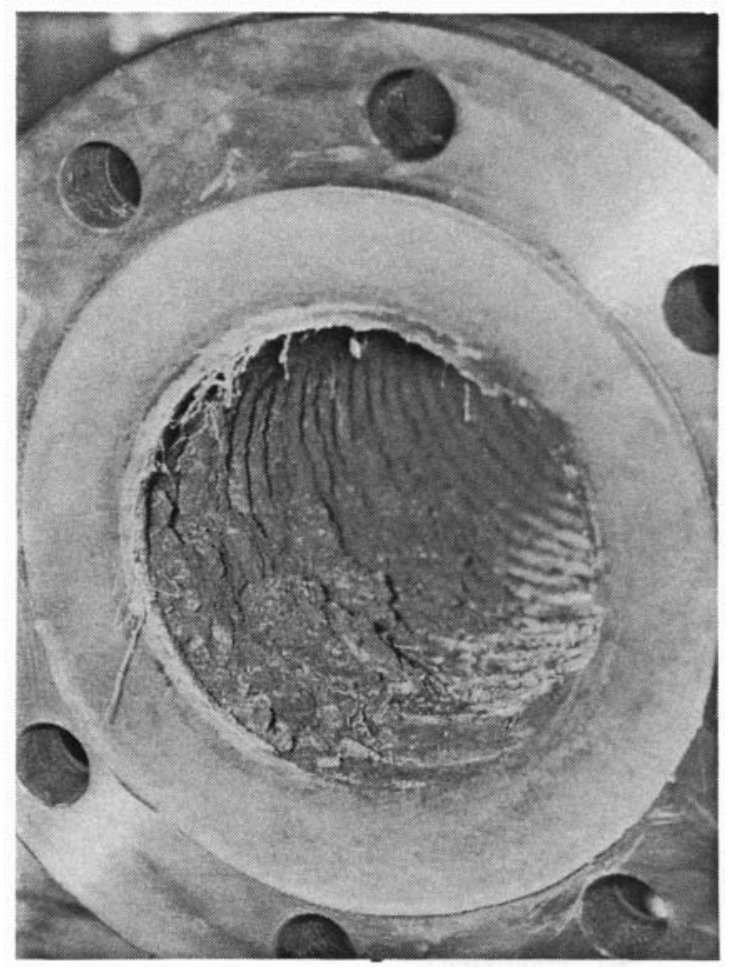

FIGURE A.58. PSCM-3 \#7

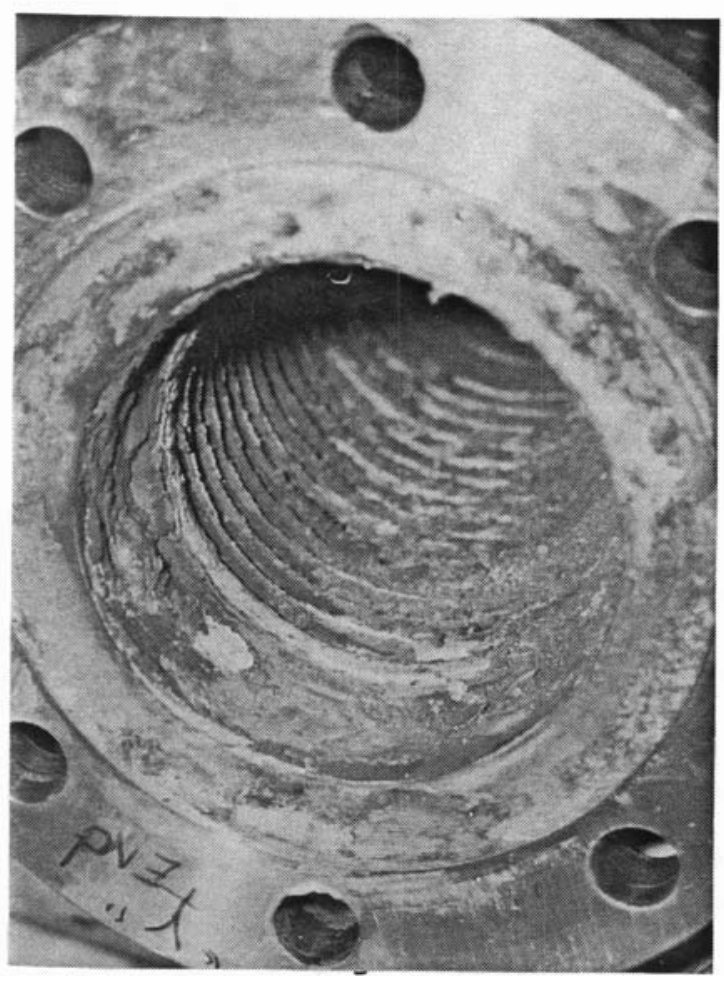

FIGURE A.57. PSCM-3 \#6

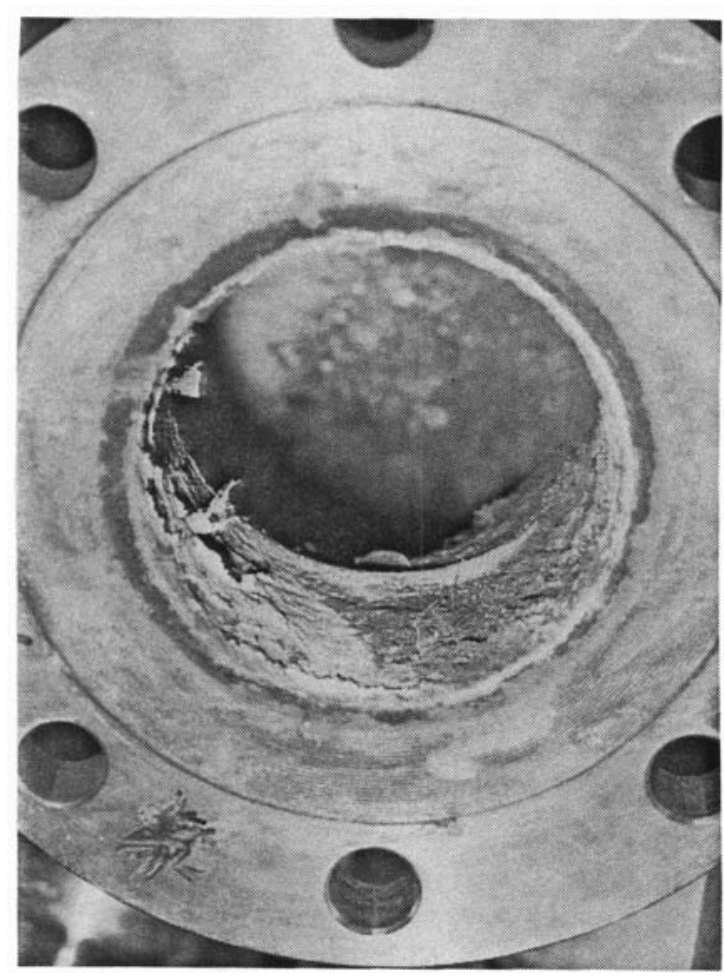

FIGURE A.59. PSCM-3 \#8 


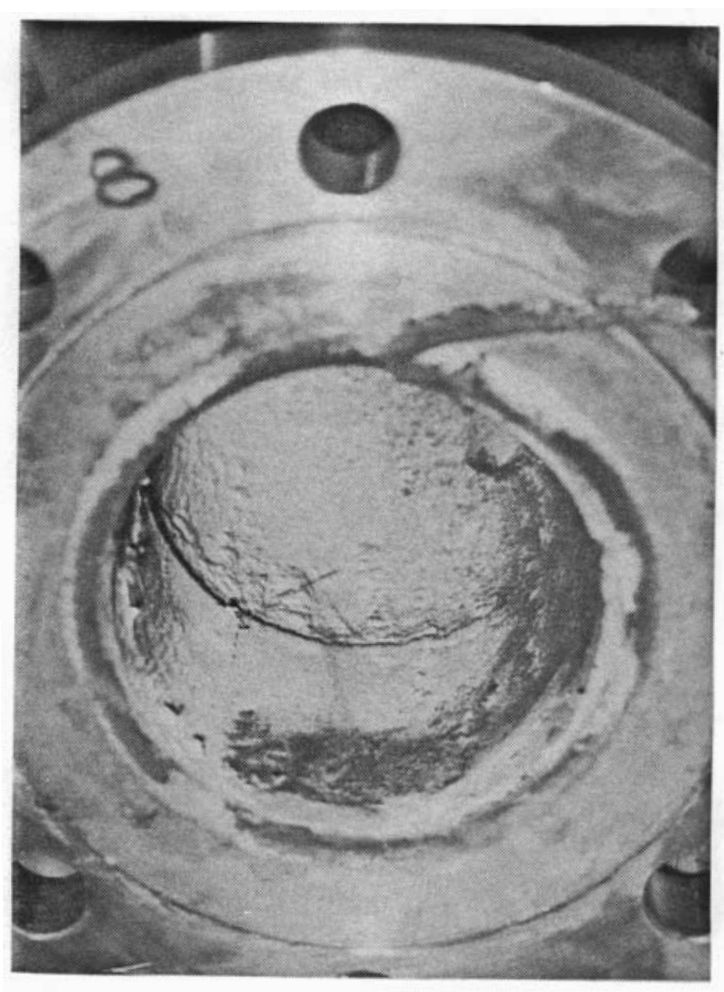

FIGURE A.60. PSCM-3 \#9

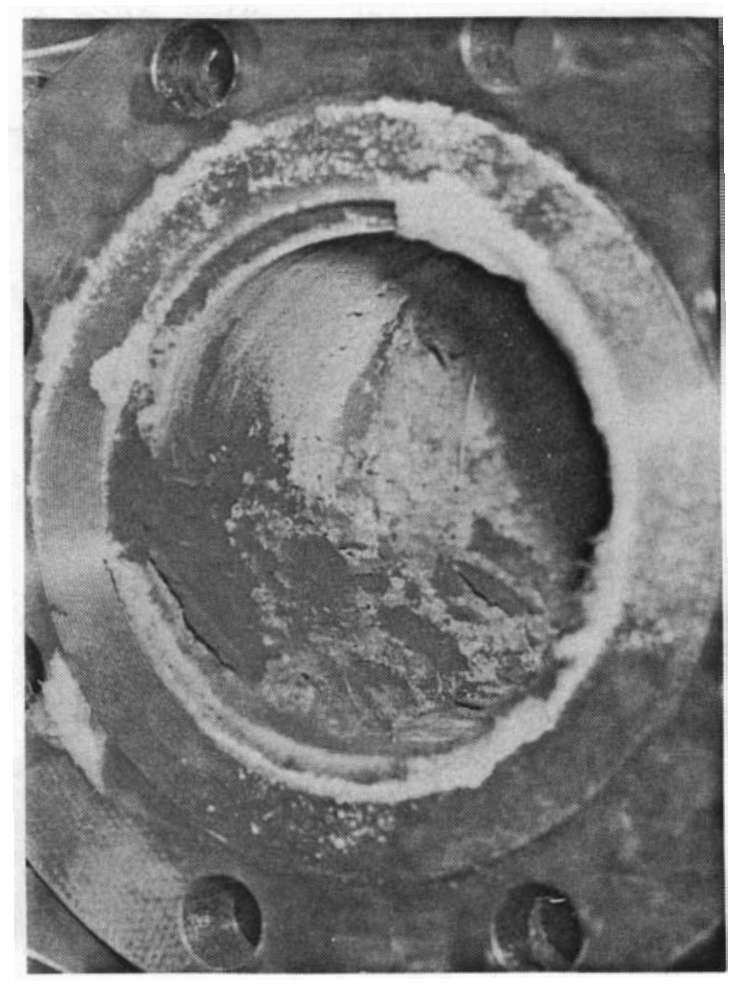

FIGURE A.61. PSCM-3 \#10

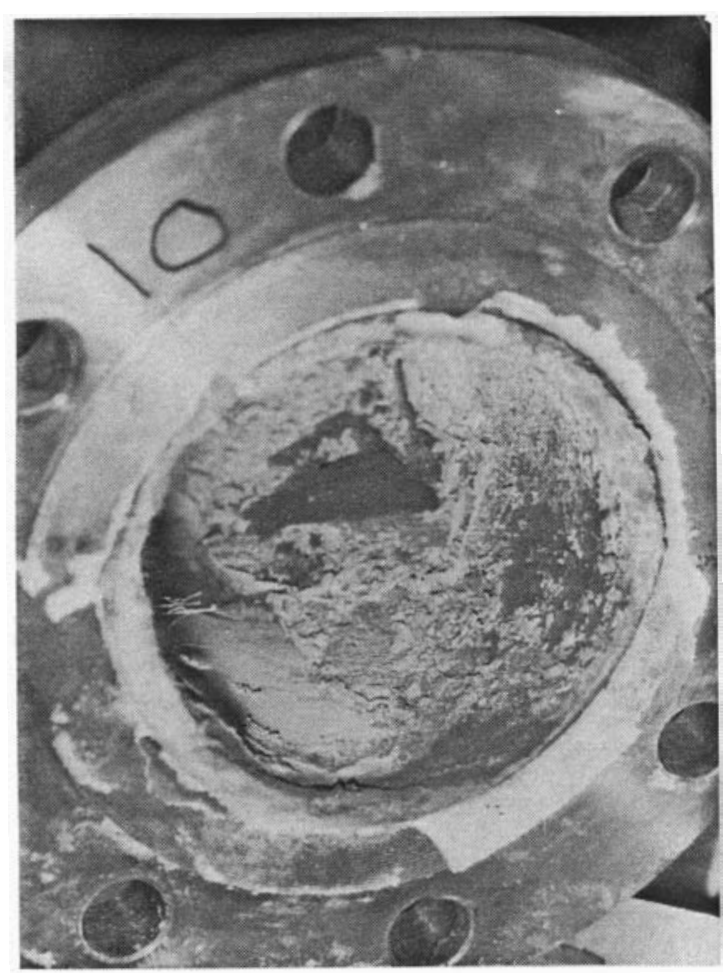

FIGURE A.62. PSCM-3 \#11 
TABLE A.21. PSCM-3 Pipe Deposition Composition

\begin{tabular}{|c|c|c|c|c|c|c|}
\hline \multirow[b]{2}{*}{$\begin{array}{l}\text { Element, } \\
\text { Oxide }\end{array}$} & \multicolumn{6}{|c|}{ Weight Percent } \\
\hline & $\begin{array}{c}\text { Lid Port } \\
\quad \# 1 \\
\end{array}$ & $\begin{array}{l}\text { Lid Port } \\
\# 15 \\
\end{array}$ & Elbow & "Y" & $\begin{array}{l}\text { Flex } \\
\text { Hose } \\
\end{array}$ & $\begin{array}{l}\text { Horizontal } \\
\text { Pipe } \\
\end{array}$ \\
\hline $\mathrm{Al}_{2} \mathrm{O}_{3}$ & 1.4 & 1.8 & 1.7 & 1.3 & 1.7 & 1.7 \\
\hline $\mathrm{B}_{2} \mathrm{O}_{3}$ & 5.0 & 5.5 & 5.5 & 5.4 & 6.0 & 5.0 \\
\hline $\mathrm{CaO}$ & 1.6 & 1.9 & 1.6 & 1.6 & 1.8 & 1.6 \\
\hline $\mathrm{CdO}$ & 0.09 & 0.08 & 0.11 & 0.15 & 0.10 & 0.09 \\
\hline $\mathrm{Cs}_{2} \mathrm{O}$ & 0.93 & 0.53 & 0.55 & 0.68 & 0.72 & 0.55 \\
\hline $\mathrm{Cr}_{2} \mathrm{O}_{3}$ & 0.14 & 0.15 & 0.21 & -- & 0.12 & 0.17 \\
\hline $\mathrm{Fe}_{2} \mathrm{O}_{3}$ & 10.2 & 12.1 & 11.3 & 10.6 & 11.7 & 10.7 \\
\hline $\mathrm{La}_{2} \mathrm{O}_{3}$ & 0.19 & 0.21 & 0.20 & 0.19 & -- & -- \\
\hline LiU & 2.5 & 2.3 & 2.5 & 2.5 & 2.5 & 2.4 \\
\hline $\mathrm{MgO}$ & 0.61 & 0.71 & 0.68 & 0.60 & 0.69 & 0.64 \\
\hline $\mathrm{MnO}_{2}$ & 4.3 & 5.3 & 4.6 & 4.3 & 4.9 & 4.8 \\
\hline $\mathrm{Na}_{2} \mathrm{O}$ & 18.5 & 14.2 & 14.5 & 18.0 & 15.0 & 14.4 \\
\hline $\mathrm{NiO}$ & 0.89 & 1.2 & 1.0 & 0.92 & 1.1 & 1.2 \\
\hline $\mathrm{RuU}_{2}$ & 0.11 & 0.04 & 0.11 & 0.03 & 0.29 & 0.08 \\
\hline $\mathrm{Sb}_{2} \mathrm{O}_{3}$ & 0.02 & 0.02 & 0.02 & 0.04 & 0.02 & 0.02 \\
\hline $\mathrm{SiO}_{2}$ & 25.0 & 28.18 & 27.1 & 25.6 & 27.9 & 25.7 \\
\hline Sro & 0.02 & 0.03 & 0.02 & 0.03 & 0.03 & 0.02 \\
\hline $\mathrm{TeO}_{2}$ & 0.13 & 0.11 & 0.14 & 0.18 & 0.16 & 0.12 \\
\hline Ti0 & 0.48 & 0.57 & 0.55 & 0.50 & 0.55 & 0.51 \\
\hline$\angle n O$ & 0.06 & 0.08 & 0.07 & 0.05 & 0.07 & -- \\
\hline $\mathrm{ZrO}_{2}$ & 0.22 & 0.26 & 0.24 & 0.22 & 0.27 & 0.24 \\
\hline $\mathrm{SeO}_{2}$ & 0.14 & 0.24 & 0.30 & 0.31 & 0.32 & 0.30 \\
\hline
\end{tabular}

The composition of the noncondensible melter exhaust yases was of particular importance duriny this experiment due to the high organic loading of the feed. The possibility of generating $\mathrm{H}_{2}$ and $\mathrm{CO}$ (water gas) in sufficient quantities to present an explosive hazard after the venturi ejector was of genuine concern. Consequently, a GC was utilized to identify all pertinent gas components present in the melter exhaust. Quantitative compositional data was yenerated by the GC for all gaseous components except $\mathrm{H}_{2}$. This data appears in 
TABLE A.22. Melter Pipe Deposit Composition

\begin{tabular}{|c|c|c|c|c|c|c|}
\hline \multirow{2}{*}{$\begin{array}{c}\text { Element, } \\
\text { Oxide }\end{array}$} & \multicolumn{6}{|c|}{ Weight Percent } \\
\hline & $\overline{\mathrm{PSCM}-3}$ & LFCM-6 & PSCM-2 & LFCM-4 & PSCM-1 & LFCM-2 \\
\hline $\mathrm{Al}_{2} \mathrm{O}_{3}$ & 1.6 & 1.9 & 1.6 & 2.0 & -- & 1.7 \\
\hline $\mathrm{B}_{2} \mathrm{O}_{3}$ & 5.4 & 7.2 & 3.4 & 5.6 & 4.6 & 4.6 \\
\hline $\mathrm{CaO}$ & 1.7 & 0.80 & 4.1 & 6.5 & -- & 4.4 \\
\hline $\mathrm{CdO}$ & 0.10 & 0.22 & 0.05 & 0.08 & -- & -- \\
\hline $\mathrm{Cs}_{2} \mathrm{O}$ & 0.66 & 0.19 & 0.11 & 0.31 & 0.80 & 0.26 \\
\hline $\mathrm{Cr}_{2} \mathrm{O}_{3}$ & 0.13 & 0.10 & 0.78 & 0.31 & -- & -- \\
\hline $\mathrm{Fe}_{2} \mathrm{O}_{3}$ & 11.1 & 12.0 & 14.2 & 14.0 & 10.0 & 20.0 \\
\hline Li0 & 2.5 & 3.1 & 2.9 & 3.4 & -- & 2.0 \\
\hline Mg0 & 0.66 & 0.90 & 0.92 & 2.5 & -- & 0.22 \\
\hline $\mathrm{MnO}_{2}$ & 4.7 & 2.2 & 3.6 & 3.4 & -- & 1.2 \\
\hline $\mathrm{Na}_{2} \mathrm{O}$ & 15.8 & 13.0 & 16.8 & 15.0 & 20.0 & 17.0 \\
\hline Ni0 & 1.1 & -- & 2.3 & -- & -- & 2.5 \\
\hline $\mathrm{RuO}_{2}$ & 0.11 & 0.47 & 0.17 & 0.16 & -- & 0.3 \\
\hline $\mathrm{Sb}_{2} \mathrm{O}_{3}$ & 0.02 & 0.03 & $<0.04$ & -- & -- & -- \\
\hline SiO & 26.6 & 32.0 & 22.7 & 31.0 & -- & 31.0 \\
\hline Sro & 0.03 & 0.02 & 0.03 & 0.05 & -- & 0.04 \\
\hline $\mathrm{TeO}_{2}$ & 0.14 & 0.06 & 0.07 & 0.11 & -- & 0.07 \\
\hline Ti0 & 0.53 & 0.72 & 0.42 & 0.11 & -- & 0.07 \\
\hline $\mathrm{ZrO}_{2}$ & 0.24 & 0.27 & 0.20 & 0.29 & -- & -- \\
\hline
\end{tabular}

Figure A.63. A bipolar response of the GC detector for $\mathrm{H}_{2}$ precluded area determination of the $\mathrm{H}_{2}$ peak. However, $\mathrm{GC}$ responses for hazardous $\mathrm{H}_{2}$ concentrations had been established previously. These served as comparative standards for the chromatograms generated during PSCM-3 and allowed operating safety, with regard to $\mathrm{H}_{2}$, to be assessed throughout this experiment. In order to obtain the molar composition of $\mathrm{H}_{2}$, grab samples were taken and analyzed by mass spectrometry. These results are included in Table A.25, which also contains a condensation of the data appearing in Figure A.63. From the data and flammability limits listed in this table, it is clear that dilution air was never required to eliminate potentially flammable conditions within the melter exhaust. However, these results also suggest that careful monitoring of 
TABLE A.23. PSCM-3 Feed Component DFS

\begin{tabular}{|c|c|c|c|}
\hline \multirow{2}{*}{$\begin{array}{l}\text { Elemental } \\
\text { Oxides }\end{array}$} & \multicolumn{3}{|c|}{ DF Values } \\
\hline & $7 / 20 / 81$ & $7 / 21 ! .81$ & Averaye \\
\hline A1 & 4800 & 7500 & 6000 \\
\hline B & 210 & 180 & 200 \\
\hline $\mathrm{Ca}$ & 1200 & 1000 & 1100 \\
\hline C1 & -- & 4 & 4 \\
\hline Cs & 5.7 & 1.9 & 3.8 \\
\hline $\mathrm{Fe}$ & 760 & 2500 & 1600 \\
\hline $\mathrm{La}$ & 3400 & 6000 & 4700 \\
\hline $\mathrm{Li}$ & 3000 & 2200 & 2600 \\
\hline $\mathrm{Mg}$ & 11000 & 5300 & 8200 \\
\hline $\mathrm{Mn}$ & 1500 & 5100 & 3300 \\
\hline $\mathrm{Na}$ & 1200 & 600 & 900 \\
\hline $\mathrm{Ni}$ & 3700 & 15000 & 9400 \\
\hline$S$ & -- & 8 & 8 \\
\hline $\mathrm{Sb}$ & $>117$ & $>670$ & -- \\
\hline$S \mathbf{i}$ & 2500 & 3600 & 3000 \\
\hline $\mathrm{Sr}$ & 560 & 720 & 640 \\
\hline $\mathrm{Te}$ & 45 & 20 & 32 \\
\hline $\mathrm{Ti}$ & 2700 & 5600 & 4100 \\
\hline $\mathrm{Zr}$ & 2500 & 1600 & 2000 \\
\hline TAL OXIDES & 970 & 990 & 980 \\
\hline
\end{tabular}

flammability conditions will have to be continued in all future experiments which utilize a formate-based feed.

The GC hydrogen response appears to be nonlinear in nature and insufficient data exists to construct a calibration curve. Because the amount of information is limited with regard to $\mathrm{H}_{2}$ generation within liquid-fed melters, a trend curve has been constructed from chromatoyraphic peak parameters which are monotonically related to concentration. It should be kept in mind that this data is not linearly related to concentration. This trend curve appears in Figure A.64.

Finally, an IR analyzer was utilized to examine the melter exhaust for the corrosive gas $\mathrm{SO}_{2}$. At the high sensitivity settinys required of this instrument, water vapor interferences proved to be an analytically limiting 
TABLE A.24. PSCM-3 Comparative DFs

\begin{tabular}{|c|c|c|c|c|c|c|c|}
\hline \multirow[b]{2}{*}{$\begin{array}{l}\text { Elemental } \\
\text { Oxides }\end{array}$} & \multirow[b]{2}{*}{$\begin{array}{l}\text { PSCM-3 } \\
\text { Avy. DF } \\
\end{array}$} & \multicolumn{6}{|c|}{ DF Ratio } \\
\hline & & $\begin{array}{l}\text { PSCM-3 } \\
\text { LFCM-2 }\end{array}$ & $\begin{array}{l}\text { PSCM-3 } 3 \\
\text { LFCM-3 }\end{array}$ & $\begin{array}{l}\text { PSCM-3 } \\
\text { PSCM-1 } \\
\end{array}$ & $\begin{array}{l}\text { PSCM-3 } \\
\text { LFCM-4 } \\
\end{array}$ & $\frac{\text { PSCM-3 }}{\text { PSCM-2 }}$ & $\begin{array}{l}\text { PSCM-3 } \\
\text { LFCM-6 } \\
\end{array}$ \\
\hline$A 1$ & 6000 & 1.2 & 2.5 & 0.55 & 11.0 & 6.1 & 18.0 \\
\hline B & 200 & 0.77 & 1.6 & 0.95 & 1.5 & 1.2 & 2.2 \\
\hline $\mathrm{Ca}$ & 1100 & 1.4 & 0.59 & 0.60 & 4.2 & 1.8 & 6.1 \\
\hline C1 & 4 & 0.22 & 0.44 & 1.3 & 1.9 & 1.3 & 2.0 \\
\hline Cs & 3.8 & 0.10 & 0.54 & 0.07 & 0.07 & 1.3 & 0.3 \\
\hline $\mathrm{Fe}$ & 1600 & 3.8 & 2.3 & 0.42 & 6.2 & 2.4 & 7.0 \\
\hline Li & 2600 & 2.8 & 3.9 & 1.4 & 8.4 & 7.6 & 16.0 \\
\hline Mg & 8200 & 17.0 & 4.6 & 0.91 & 23.0 & 8.9 & 32.0 \\
\hline $\mathrm{Mn}$ & 3300 & 2.1 & 1.1 & 0.58 & 7.9 & 5.02 & 10.0 \\
\hline $\mathrm{Na}$ & 900 & 2.7 & 3.2 & 1.1 & 2.6 & 6.9 & 10.0 \\
\hline $\mathrm{Ni}$ & 9400 & 22.0 & 22.0 & 6.3 & 36.0 & -- & 10.0 \\
\hline$S$ & 8 & -- & 1.6 & 8.0 & 8.0 & 0.44 & 0.73 \\
\hline Sì & 3000 & 3.2 & 1.1 & 0.20 & 7.1 & 1.9 & 11.0 \\
\hline $\mathrm{Sr}$ & 640 & 1.7 & 0.43 & 0.09 & 3.1 & 1.0 & 2.2 \\
\hline $\mathrm{Te}$ & 32 & 0.52 & 0.12 & 0.19 & 0.52 & 0.55 & 0.15 \\
\hline $\mathrm{Ti}$ & 4100 & 3.7 & -- & -- & -- & 2.79 & 24.0 \\
\hline OTAL OXIDE & 980 & 1.7 & 2.0 & $\overline{0.86}$ & 3.4 & 2.3 & 5.8 \\
\hline
\end{tabular}

variable. Consequently, no conclusive data was generated with reyard to melter-generated $\mathrm{SO}_{2}$ emissions during PSCM-3. Further $\mathrm{SO}_{2}$ monitoring studies will be discussed in the LFCM-7 effluents section.

\section{$\underline{\text { LFCM-7 - AUGUST } 1981}$}

LFCh-7 represented the second liquid-fed melter experiment utiliziny a formate-based slurry feed. Unlike the first test run (PSCM-3), LFCM-7 employed electric lid-heat boosting to maximize feeding rates. However, the run was structured to allow sampling to be conducted at various feediny rates with and without lid heat. One of the major objectives of this melter run was to evaluate real time off-gas- 1 ine cleaning techniques. Consequently, the post-run examination of the off-yas line was not carried out. However, it was observed that off-yas depositions were quite light and easily removed. None of the formations observed could have yrown into local off-gas line restrictions. 


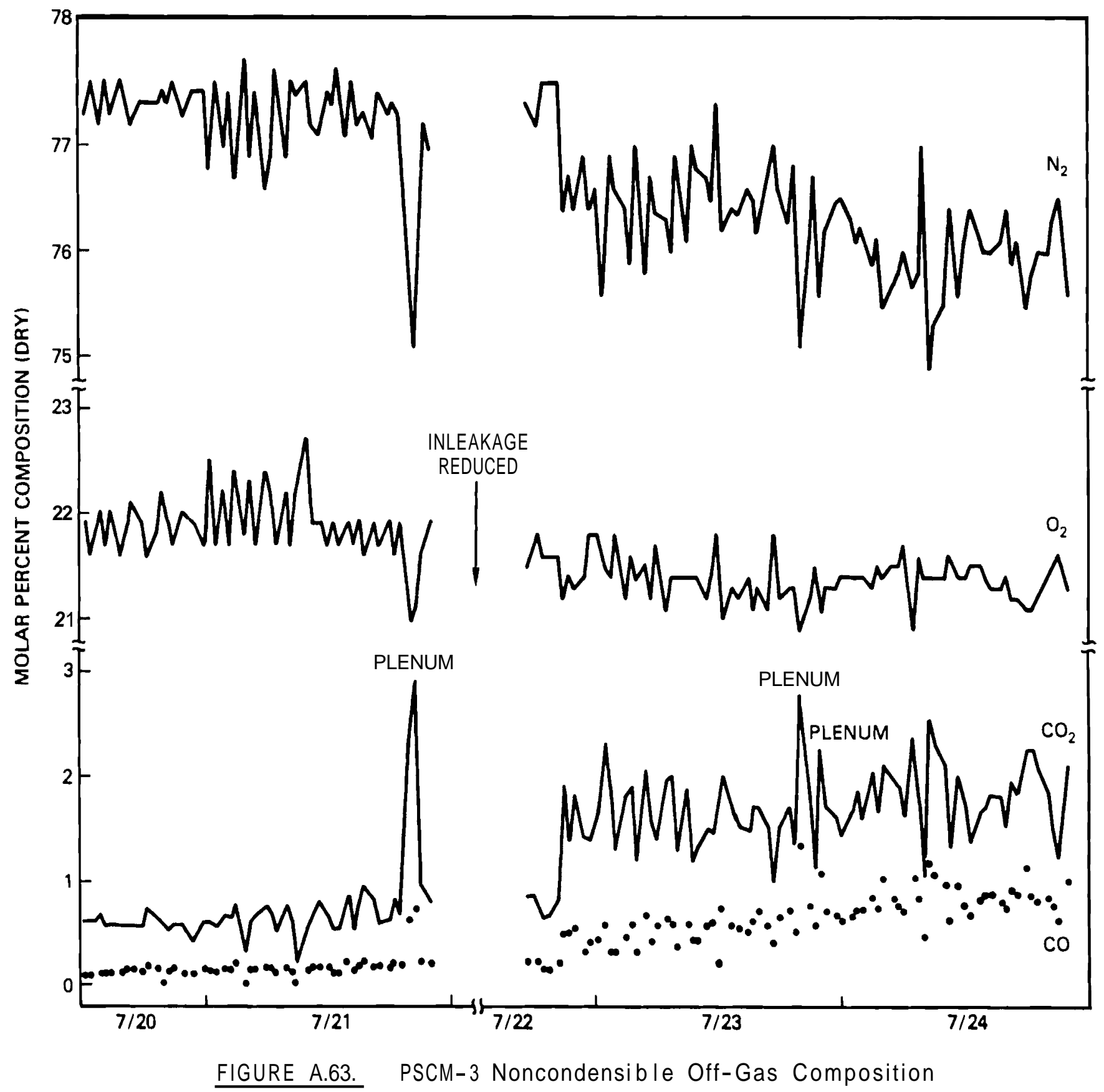

Effluent sampling of LFCM-7 emphasized the characterization of melteryenerated aerosols. Sampliny was conducted in order to establish the size distributions and concentrations of entrained particulate matter as a function of melter feeding rates. Size distribution information was obtained from a cyclone sampler consisting of a series arrangement of three cyclones and a 
TABLE A.25. PSCM-3 Off-Gas Composition

\begin{tabular}{|c|c|c|c|c|c|c|c|}
\hline \multirow[b]{3}{*}{ Date } & \multirow{3}{*}{$\begin{array}{l}\text { Data } \\
\text { Type }\end{array}$} & \multicolumn{6}{|c|}{ Molar Composition, \% } \\
\hline & & & & $\mathrm{YBas}$ & & & \\
\hline & & $\underline{\mathrm{CO}_{2}}$ & $\mathrm{O}_{2}(\mathrm{a})$ & $\mathrm{N}_{2}$ & $\mathrm{CO}^{(\mathrm{b})}$ & $\mathrm{H}_{2}(\mathrm{~b})$ & $\mathrm{H}_{2} \mathrm{O}$ \\
\hline $7 / 20$ & Avg. & 0.60 & 21.8 & 77.4 & 0.14 & -- & -- \\
\hline $7 / 21$ & Avy. & 0.79 & 21.9 & 74.8 & 0.19 & -- & -- \\
\hline $7 / 22$ & Avg. & 1.65 & 21.5 & 77.0 & 0.32 & -- & 48 \\
\hline $7 / 23$ & Avg. & 1.42 & 21.3 & 76.1 & 0.58 & 0.64 & 74 \\
\hline $7 / 24$ & Avy. & 1.83 & 21.6 & 76.0 & 0.83 & -- & -- \\
\hline $7 / 20-7 / 24$ & $\mathrm{Hi}$ & 2.94 & 22.7 & 77.13 & 1.31 & 1 _ I I & $N / A$ \\
\hline $7 / 20-7 / 24$ & Lo & 0.20 & 20.9 & 75.1 & 0.04 & 0.17 & $N / A$ \\
\hline
\end{tabular}

(a) Includes -1\%argon.

(b) Lower flammability limit in air: $\mathrm{H}_{2}-4 \%$; $\mathrm{CO}-12.5 \%$.

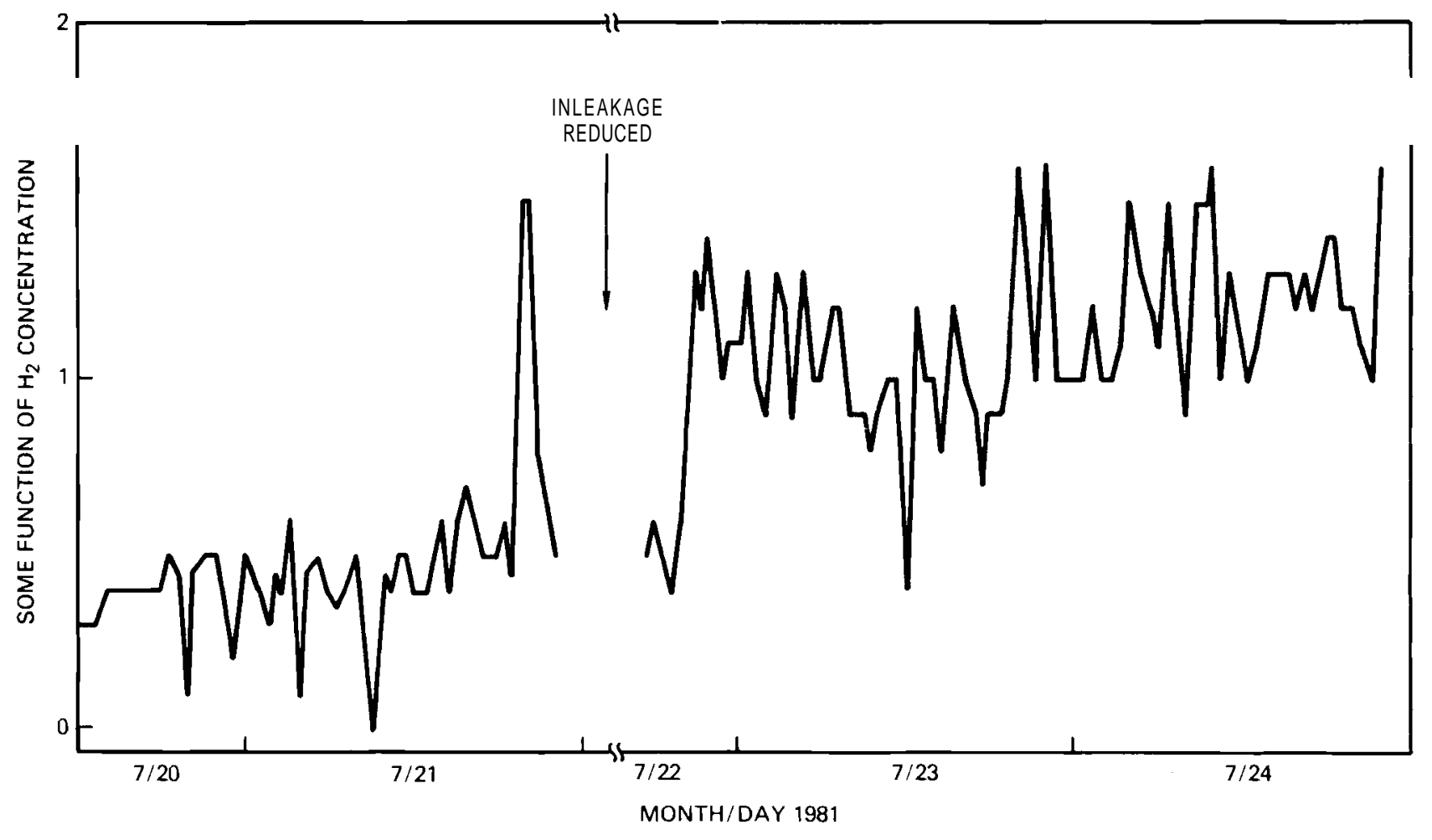

FIGURE A.64. $\quad \mathrm{H}_{2}$ Variation During PSCM-3 
final absolute filter. The cut points of the cyclones employed were $16 \mu m$, $6 \mu \mathrm{m}$ and $1 \mu \mathrm{m}$. The absolute final filter is designed to collect submicron fines which are able to pass throuyh all three preceding cyclones.

The data generated with this differential filtering system are summarized in Table A.26. The distribution of particulates yenerated by LFCM-7 is clearly bimodal in nature. Compositional analysis of these size fractions, including the condensate, appear in Table A.27. Clearly, the compositions of the various size fractions differ markedly with the semivolatile constituents strongly concentrated in the submicron fraction. This fact suygests that the two distributions makiny up the overall bimodal distribution probably result from independent processes.

Also presented in Table A.26 are total particulate off-gas loadings and total melter entrainment DFs. Neither of these quantities nor the size distribution data seem to be correlated with feediny or glass-production rates that occurred duriny the various sampling periods. However, sampliny times were relatively short and feeding rates were fairly erratic.

Total aerosol loadiny of the off-gas stream was also assessed at various times during the run by divertiny al1 off-gas flow through a prewei yhed HEPA filter. The net (dry) weiyht gains of these filters were then compared with the quantity of glass produced duriny the filtration periods to obtain total melter DFs. Concentration information was obtained through use of total offyas flow rates, which were recorded continuously throughout the run. This data

TABLE A.26. Differential Particulate Data

\begin{tabular}{|c|c|c|c|c|c|c|c|c|c|}
\hline Date & $\begin{array}{c}\text { Sampling } \\
\text { Period }\end{array}$ & $\begin{array}{l}w+\% \\
16 \mu \mathrm{m} \\
\end{array}$ & $\begin{array}{c}\text { Versus } \\
6 \mu \mathrm{m} \\
\end{array}$ & $\begin{array}{c}\text { Cut Po } \\
1 \mu \mathrm{m}\end{array}$ & $\frac{\mathrm{nt}}{<1 \mu \mathrm{m}}$ & $\underset{\mathrm{mg} / \mathrm{L}}{\text { Loading, }}$ & DF & $\begin{array}{l}\text { Average } \\
\text { Glass, } \\
\mathrm{kg} / \mathrm{min}\end{array}$ & $\begin{array}{c}\text { Rates } \\
\text { Feed, } \\
\mathrm{L} / \mathrm{min}\end{array}$ \\
\hline $8 / 24$ & $0727-0925$ & 79.5 & 20 & 10.2 & 8.3 & 11 & 100 & -- & 0.85 \\
\hline $8 / 24$ & $1635-1805$ & 65.3 & 66 & 14.6 & 13.5 & 6.7 & 170 & 0.46 & 0.95 \\
\hline $8 / 25$ & $0553-0640$ & 86.2 & 24 & 61 & 52 & 17 & 80 & 0.46 & 13 \\
\hline $8 / 25$ & $1415-1515$ & 74.2 & 27 & 9.4 & 13.7 & 6.8 & 250 & 0.82 & 16 \\
\hline $8 / 27$ & $0811-0831$ & 78.4 & 03 & 24 & 189 & 18 & 120 & 0.73 & 2.4 \\
\hline $8 / 24-27$ & Average & 76.7 & 28 & 8.5 & 11.9 & 3.5 & 140 & - & - \\
\hline
\end{tabular}

(a) Actual steam-loaded volume reduced to STP. 
TABLE A.27. Elemental Distribution Across Cyclonic Sampling System

Elemental Distribution, \%

\begin{tabular}{|c|c|c|c|c|c|c|c|c|c|c|}
\hline \multirow[b]{2}{*}{ Element } & \multicolumn{5}{|c|}{ Sample Fraction $8 / 25 / 81$} & \multirow{2}{*}{\multicolumn{5}{|c|}{ Sample Fraction $8 / 27 / 81$}} \\
\hline & $16 \mu \mathrm{m}$ & $6 \mu \mathrm{m}$ & $1 \mu \mathrm{m}$ & $\leq 1 \mu \mathrm{m}$ & Cond. & $16 \mu \mathrm{m}$ & & & $<1 \mu m$ & Cond. \\
\hline Al & 95.93 & 0.90 & 2.48 & 0.41 & 0.21 & 97.68 & -- & 0.65 & 1.49 & 0.18 \\
\hline B & 35.28 & 0.72 & 3.15 & 1.06 & 59.8 & 55.75 & -- & 0.80 & 0.87 & 42.58 \\
\hline $\mathrm{Ba}$ & 83.72 & 5.75 & 10.53 & -- & -- & 97.0 & -- & 3.0 & -- & -- \\
\hline $\mathrm{Ca}$ & 77.42 & 2.70 & 15.11 & 4.45 & 0.32 & 88.87 & -- & 3.84 & 5.30 & 1.99 \\
\hline $\mathrm{Cd}$ & 10.66 & 0.86 & 7.32 & 81.17 & -- & 11.29 & -- & 3.94 & 84.76 & -- \\
\hline $\mathrm{Ce}$ & 92.08 & -- & 7.92 & -- & -- & & & & & \\
\hline $\mathrm{Cr}$ & 46.40 & 21.70 & 23.31 & 8.59 & -- & 98.58 & -- & 1.42 & -- & -- \\
\hline Cs & 7.49 & -- & 5.41 & 87.10 & -- & 13.79 & -- & 2.20 & 84.01 & -- \\
\hline $\mathrm{Cu}$ & 82.64 & 4.85 & 4.23 & 8.27 & -- & 60.83 & -- & 4.99 & 34.19 & -- \\
\hline $\mathrm{Fe}$ & 72.12 & 2.56 & 16.97 & 3.14 & 0.20 & 92.19 & -- & 3.98 & 3.48 & 0.36 \\
\hline La & 91.95 & 1.48 & 6.09 & 0.48 & -- & 98.84 & -- & 1.16 & -- & -- \\
\hline Li & 83.16 & 1.54 & 5.32 & 9.98 & -- & 87.46 & -- & 0.99 & 11.55 & -- \\
\hline My & y1.52 & 1.60 & 5.79 & 1.08 & -- & 95.31 & -- & 1.29 & 3.40 & -- \\
\hline $\mathrm{Mn}$ & 89.38 & 6.41 & 3.61 & 0.61 & -- & 93.99 & -- & 3.27 & 2.61 & 0.13 \\
\hline Mo & 77.46 & 5.62 & 9.80 & 7.12 & -- & 68.65 & -- & 31.35 & -- & -- \\
\hline $\mathrm{Na}$ & 68.80 & 1.70 & 5.62 & 23.86 & 0.03 & 66.52 & -- & 1.25 & 32.15 & 0.08 \\
\hline $\mathrm{Nd}$ & 93.45 & -- & 6.55 & -- & -- & 100.0 & -- & -- & -- & -- \\
\hline $\mathrm{Ni}$ & -- & -- & -- & -- & 100.0 & -- & -- & -- & -- & 100.0 \\
\hline $\mathrm{Pb}$ & -- & -- & -- & -- & -- & -- & -- & 5.62 & 94.38 & -- \\
\hline $\mathrm{Sb}$ & 100.0 & -- & -- & - & -- & -- & -- & -- & -- & -- \\
\hline $\mathrm{Se}$ & 56.89 & 1.92 & 11.36 & 29.83 & -- & 87.25 & -- & 2.85 & 9.90 & -- \\
\hline Si & 91.86 & 1.79 & 5.61 & 0.60 & 0.14 & 96.71 & -- & 1.15 & 1.24 & 0.89 \\
\hline $\mathrm{Sr}$ & 77.57 & 2.80 & 19.62 & -- & -- & 95.56 & -- & 4.44 & -- & -- \\
\hline Te & 5.48 & 0.39 & 3.22 & 90.91 & -- & -- & -- & 4.97 & 95.03 & -- \\
\hline $\mathrm{Ti}$ & 91.19 & 1.80 & 6.04 & 0.96 & -- & 97.88 & -- & 0.98 & 1.14 & -- \\
\hline $\mathrm{Zr}$ & 90.58 & 1.58 & 5.52 & 1.24 & 1.09 & 81.07 & -- & 0.98 & 2.28 & 15.68 \\
\hline
\end{tabular}

is presented in Table A.28 alony with ylass production rates. Again, no clear correlation appears to exist relating aerosol emission rates with feeding or glass production rates. Moreover, the average DF value (130) established with these filters is lower than the values achieved by the two previous LFCM experiments, which were 600 for LFCM-4 and 170 for LFCM-6. However, it compares quite well with the cyclonically derived value of 140 . 
TABLE A.28. HEPA Filtration Data

\begin{tabular}{|c|c|c|c|c|c|c|}
\hline Date & $\begin{array}{l}\text { Sampliny } \\
\text { Period }\end{array}$ & $\begin{array}{l}\text { Sample } \\
\text { Wei yht, } \\
y\end{array}$ & $\begin{array}{l}\text { Glass } \\
\text { Rate, } \\
\mathrm{ky} / \mathrm{min} \\
\end{array}$ & 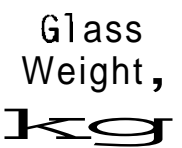 & $\begin{array}{c}\text { Loading, (a) } \\
\mathrm{mg} / \mathrm{L}\end{array}$ & $\mathrm{DF}$ \\
\hline $8 / 24$ & $0805-1013$ & 390 & 0.25 & 32 & 0.45 & 82 \\
\hline $8 / 25$ & $0648-0815$ & 370 & 0.59 & 51 & 0.63 & 137 \\
\hline $8 / 25$ & $2233-2336$ & 360 & 0.97 & 61 & 0.84 & 170 \\
\hline $8 / 27$ & $0900-0938$ & 420 & 0.98 & 37 & 1.6 & 89 \\
\hline $8 / 28$ & $0442-0534$ & 360 & 1.1 & 57 & 1.0 & 158 \\
\hline $8 / 24-28$ & Average & $\overline{---}$ & -- & $\overline{--}$ & 0.9 & $\overline{130}$ \\
\hline
\end{tabular}

(a) Based on an average total flow rate reduced to STP.

Additional off-yas particulate loading data were also generated by the prefilter associated with the off-gas differential sampliny apparatus. This data is summarized in Table A.29. These particulate samples were collected over relatively lony periods of time and thus should be less sensitive to the erratic nature of the LFCM-7 feediny rates. As with the previous data, off-gas loading and DFs are compared to feediny and ylass production rates averaged over the sampling intervals. This data does exhibit a weak correlation between feediny or ylass production rates and total particulate off-gas loading conditions. However, the quantity of entrained material per unit weight of feed processed (DF) appears to be independent of the feediny rates. In other words, this suggests that DFs are independent of the extent of development of the melter cold cap.

Particulate and total melter feed component DFs associated with the LFCM-7 test have been established for most elemental constituents (see Table A.30). A comparison of average LFCM-7 DFs with results obtained from previous melter experiments is presented in Table A.31. Clearly, melter effluent emission rates associated with the LFCM-7 experiment were, with few exceptions, the highest ever recorded since effluent studies began in Auyust 1980 . However, the averaye LFCM-7 melter DF value for Cs is higher than has been achieved in the previous three melter tests. 
TABLE A.29. Particulate Data From Off-Gas Sampling Train

\begin{tabular}{|c|c|c|c|c|c|c|}
\hline \multirow[b]{2}{*}{ Date } & \multirow[b]{2}{*}{$\begin{array}{l}\text { Sampling } \\
\text { Period }\end{array}$} & \multirow[b]{2}{*}{$\begin{array}{l}\text { Net Sample } \\
\text { Wei yht, } y\end{array}$} & \multicolumn{2}{|c|}{ Particulate } & \multicolumn{2}{|c|}{ Average Rates } \\
\hline & & & $\begin{array}{c}\text { Loading, (a) } \\
\mathrm{mg} / \mathrm{L}\end{array}$ & $\mathrm{DE}$ & $\begin{array}{r}\text { Glass, } \\
\mathrm{kg} / \mathrm{m}\end{array}$ & $\begin{array}{l}\text { Feed, } \\
\mathrm{L} / \mathrm{m}\end{array}$ \\
\hline $8 / 24$ & $0913-1615$ & 2.7 & 1.9 & 50 & U.34 & 0.98 \\
\hline $8 / 25$ & $0840-1530$ & 3.2 & 2.2 & 65 & 0.59 & 1.2 \\
\hline $8 / 26$ & $0833-1804$ & 3.8 & 3.8 & 45 & 0.79 & 1.8 \\
\hline $8 / 27$ & $0857-1806$ & 2.8 & 3.8 & 65 & 0.70 & 2.0 \\
\hline $8 / 28$ & $0830-1246$ & 1.6 & 2.0 & 130 & 1.6 & 2.7 \\
\hline $8 / 24-27$ & Average & -- & 2.7 & 71 & -- & -- \\
\hline
\end{tabular}

(a) STP.

TABLE H.30. Particulate and Total Feed Component DFs

\begin{tabular}{|c|c|c|c|c|c|c|c|c|c|c|c|c|}
\hline \multirow[b]{3}{*}{ El ement } & \multicolumn{12}{|c|}{ Melter DFs } \\
\hline & \multicolumn{2}{|c|}{$8 / 24$} & \multicolumn{2}{|c|}{$8 / 25$} & \multicolumn{2}{|c|}{$8 / 26$} & \multicolumn{2}{|c|}{$8 / 27$} & \multicolumn{2}{|c|}{$8 / 28$} & \multicolumn{2}{|c|}{ Ave. } \\
\hline & Part & Total & Part & Total & Part & Total & Part & Total & part & Total & Part & Total \\
\hline Al & 136 & 132 & 92 & 91 & 71 & 71 & 139 & 139 & 540 & 530 & 200 & 190 \\
\hline B & 56 & 44 & 72 & 53 & 59 & 46 & 103 & 80 & 260 & 150 & 110 & 75 \\
\hline $\mathrm{Ca}$ & 41 & 40 & 52 & 52 & 36 & 36 & 63 & 63 & 120 & 120 & 62 & 62 \\
\hline $\mathrm{Cd}$ & 11 & 10 & 8.1 & 8.1 & 5.3 & 5.3 & 6.6 & 6.6 & 10 & 10 & 8.2 & 8.0 \\
\hline Cs & 16 & 16 & 24 & 24 & 9 & 9 & 4.5 & 4.5 & 5.9 & 5.9 & 12 & 12 \\
\hline $\mathrm{Fe}$ & 48 & 48 & 65 & 65 & 49 & 48 & 64 & 63 & 130 & 120 & 71 & 69 \\
\hline La & -- & -- & 92 & 92 & 69 & 69 & 109 & 109 & 290 & 290 & 140 & 140 \\
\hline Li & 52 & 57 & 66 & 66 & 55 & 55 & 77 & 77 & 200 & 190 & 90 & 89 \\
\hline $\mathrm{Mg}$ & 79 & 78 & 89 & 89 & 66 & 66 & 106 & 106 & 270 & 270 & 120 & 120 \\
\hline Mn & 46 & 46 & 64 & 64 & 44 & 44 & 64 & 64 & 162 & 160 & 76 & 76 \\
\hline $\mathrm{Na}$ & 50 & 50 & 65 & 64 & 43 & 43 & 50 & 50 & 93 & 91 & 60 & 60 \\
\hline $\mathrm{Ru}$ & -- & -- & -- & -- & 16 & 16 & -- & -- & -- & -- & 16 & 16 \\
\hline $\mathrm{Sb}$ & 54 & 54 & 86 & 86 & 62 & 62 & -- & - & -- & - & 67 & 67 \\
\hline $\mathrm{Se}$ & -- & - & 1 & 1 & -- & - & - & -- & - & - & 1 & 1 \\
\hline $\mathrm{Si}$ & 70 & 70 & 82 & 82 & 65 & 65 & 102 & 101 & 270 & 260 & 120 & 120 \\
\hline $\mathrm{Sr}$ & 35 & 35 & 44 & 44 & 32 & 32 & 45 & 45 & 140 & 140 & 55 & 55 \\
\hline $\mathrm{Te}$ & 6.4 & 6.3 & 3.3 & 3.3 & 4 & 4 & 6.1 & 6.1 & 8.5 & 8.5 & 5.7 & 5.6 \\
\hline $\mathrm{Ti}$ & 73 & 73 & 91 & 91 & 66 & 66 & 106 & 106 & 280 & 280 & 120 & 120 \\
\hline $\mathrm{Zr}$ & 78 & 78 & 94 & 94 & 63 & 63 & 95 & 95 & 270 & 270 & 120 & 120 \\
\hline
\end{tabular}


TABLE A.31. LFCM-7 Comparative DFs

\begin{tabular}{|c|c|c|c|c|c|c|c|c|}
\hline \multirow[b]{3}{*}{ Element } & \multirow{3}{*}{$\begin{array}{l}\text { LFCM-7 } \\
\text { Avg DF }\end{array}$} & \multicolumn{7}{|c|}{ DF Ratio } \\
\hline & & LFCM-7 & LFCM-7 & LFCM-7 & LFCM-7 & LFCM-7 & LFCM-7 & LFCM-7 \\
\hline & & PSCM-3 & LFCM-6 & $\mathrm{PSCM}-2$ & $\mathrm{LFCM}-4$ & PSCM-1 & LFCM-3 & LFCM-2 \\
\hline Al & 190 & 0.03 & 0.58 & 0.13 & 0.35 & 0.02 & 0.08 & 0.04 \\
\hline B & 75 & 0.38 & 0.83 & 0.47 & 0.58 & 0.36 & 0.62 & 0.29 \\
\hline $\mathrm{Ca}$ & 62 & 0.06 & 0.34 & 0.10 & 0.24 & 0.03 & 0.03 & 0.08 \\
\hline $\mathrm{Cd}$ & 8 & -- & 0.10 & 0.17 & 0.11 & 0.04 & 0.10 & -- \\
\hline Cs & 12 & 3.2 & 1.2 & 4.0 & 0.21 & 0.24 & 1.7 & 0.30 \\
\hline $\mathrm{Fe}$ & 69 & 0.04 & 0.30 & 0.10 & 0.27 & 0.02 & 0.10 & 0.16 \\
\hline Li & 89 & 0.03 & 0.56 & 0.10 & 0.25 & 0.01 & 0.05 & 0.18 \\
\hline $\mathrm{Mg}$ & 120 & 0.01 & 0.46 & 0.13 & 0.34 & 0.01 & 0.07 & 0.25 \\
\hline $\mathrm{Mh}$ & 76 & 0.02 & 0.23 & 0.12 & 0.18 & 0.01 & 0.02 & 0.05 \\
\hline $\mathrm{Na}$ & 60 & 0.07 & 0.67 & 0.46 & 0.18 & 0.07 & 0.21 & 0.18 \\
\hline $\mathrm{Ru}$ & 16 & - & 1.23 & 0.33 & 0.62 & 0.50 & 0.27 & 2.3 \\
\hline $\mathrm{Sb}$ & 67 & -- & - & 0.67 & 0.04 & - & -- & 0.14 \\
\hline Se & 1 & -- & -- & -- & - & -- & - & 0.004 \\
\hline$S \mathbf{S}$ & 120 & 0.04 & 0.43 & 0.08 & 0.29 & 0.01 & 0.05 & 0.13 \\
\hline $\mathrm{Sr}$ & 55 & 0.09 & 0.19 & 0.09 & 0.27 & 0.01 & 0.04 & 0.15 \\
\hline $\mathrm{Te}$ & 5.6 & 0.18 & 0.03 & 0.10 & 0.09 & 0.03 & 0.02 & 0.09 \\
\hline $\mathrm{Ti}$ & 120 & 0.03 & 0.71 & 0.09 & -- & -- & - & 0.11 \\
\hline
\end{tabular}

Gross melter entrainment has been measured by several different approaches and at many different feed rates during LFCM-7. Table A.32 is a collection of all the yross $D F$ values established during this experiment.

Due to the potential hazards associated with melter-generated $\mathrm{H}_{2}$ and $\mathrm{CO}$, noncondensible yas monitoring was conducted throuyhout the duration of LFCM-7. As in PSCM-3, the gas samples were extracted and analyzed by a GC at the exhaust of the venturi ejector (see Fiyure A.I). The compositional data yenerated with this sampling system is yraphically illustrated in Fiyure A.65. The inleakaye rates $(90 \mathrm{scfm})$ for LFCM-7 were much yreater than those occurring during the previous PSCM-3 test $(-20 \mathrm{scfm})$. Consequently, $\mathrm{CO}$ and $\mathrm{H}_{2}$ concentrations were never much of a safety concern throuyhout the run. In fact, $\mathrm{H}_{2}$ was hardly detectable until one of the laryer off-gas leaks was eliminated 
TABLE A.32. Gross DF Values

\begin{tabular}{|c|c|c|c|c|c|c|}
\hline \multirow[b]{3}{*}{ Date } & \multirow{2}{*}{\multicolumn{2}{|c|}{ Sarnpling }} & \multicolumn{2}{|c|}{ Particulate } & \multicolumn{2}{|c|}{ Average Rates } \\
\hline & & & \multirow{2}{*}{$\begin{array}{c}\text { Loading, (b) } \\
\mathrm{mg} / \mathrm{L}\end{array}$} & \multirow[b]{2}{*}{$\mathrm{DF}$} & Glass, & Feed, \\
\hline & Period & Type (a) & & & $\mathrm{kg} / \mathrm{m}$ & \\
\hline $8 / 24$ & $0727-0925$ & C & 1.08 & 120 & - & 0.85 \\
\hline $8 / 24$ & $0805-1013$ & HEPA & 0.45 & 82 & 0.25 & -- \\
\hline $8 / 24$ & $0913-1615$ & $S$ & 1.90 & 50 & 0.34 & 0.98 \\
\hline $8 / 24$ & $1635-1805$ & c & 0.67 & 170 & 0.46 & 0.95 \\
\hline $8 / 25$ & $0553-0640$ & C & 1.70 & 80 & 0.46 & 1.3 \\
\hline $8 / 25$ & $0648-0815$ & HEPA & 0.63 & 137 & 0.59 & -- \\
\hline $8 / 25$ & $0840-1530$ & $S$ & 2.2 & 65 & 0.59 & 1.2 \\
\hline $8 / 25$ & $1415-1515$ & C & 0.67 & 245 & 0.82 & 1.6 \\
\hline $8 / 25$ & $2233-2336$ & HEPA & 0.84 & 170 & 0.97 & -- \\
\hline $8 / 26$ & $0833-1804$ & $S$ & 3.8 & 45 & 0.79 & 1.8 \\
\hline $8 / 27$ & $0811-0831$ & c & 1.8 & 120 & 0.73 & 2.4 \\
\hline $8 / 27$ & $0900-0938$ & HEPA & 1.6 & 89 & 0.98 & -- \\
\hline $8 / 27$ & $0857-1806$ & $S$ & 3.8 & 65 & 0.70 & 2.0 \\
\hline $8 / 28$ & $0442-0534$ & HEPA & 1.0 & 158 & 1.1 & -- \\
\hline $8 / 28$ & $0830-1246$ & $S$ & 2.0 & 130 & -- & 2.7 \\
\hline $8 / 24-28$ & Average & ALL & $\overline{1.61}$ & 115 & & \\
\hline
\end{tabular}

(a) $C=$ cyclone $\quad S=$ differential sampler HEPA = absolute filtration. (b) STP.

toward the end of the run. As in PSCM-3, $\mathrm{H}_{2}$ concentrations were established using a gas mass spectrometer. This data, along with a condensation of the results appearing in Figure A.65, is presented in Table A.33. A curve showing $\mathrm{H}_{2}$ concentration as a function of time, has been constructed from the GC data (see Section "PSCM-3, JULY 1981"). This curve, displayed in Figure A.66, is designed to give the reader a semiquantitative notion of the way in which $\mathrm{H}_{2}$ concentrations varied throughout the LFCM-7 experiment. The reader is cautioned that the correlation presented in this figure is nonlinear.

The sampling difficulties encountered with the $\mathrm{SO}_{2}$ monitor during PSCM-3 were eliminated, allowing $\mathrm{SO}_{2}$ to be monitored during LFCM-7. However, no significant responses were recorded during the sampling periods ernployed. Thus, the upper concentration limit of $\mathrm{SO}_{2}$ in the rnelter exhaust is $50 \mathrm{ppm}$. 


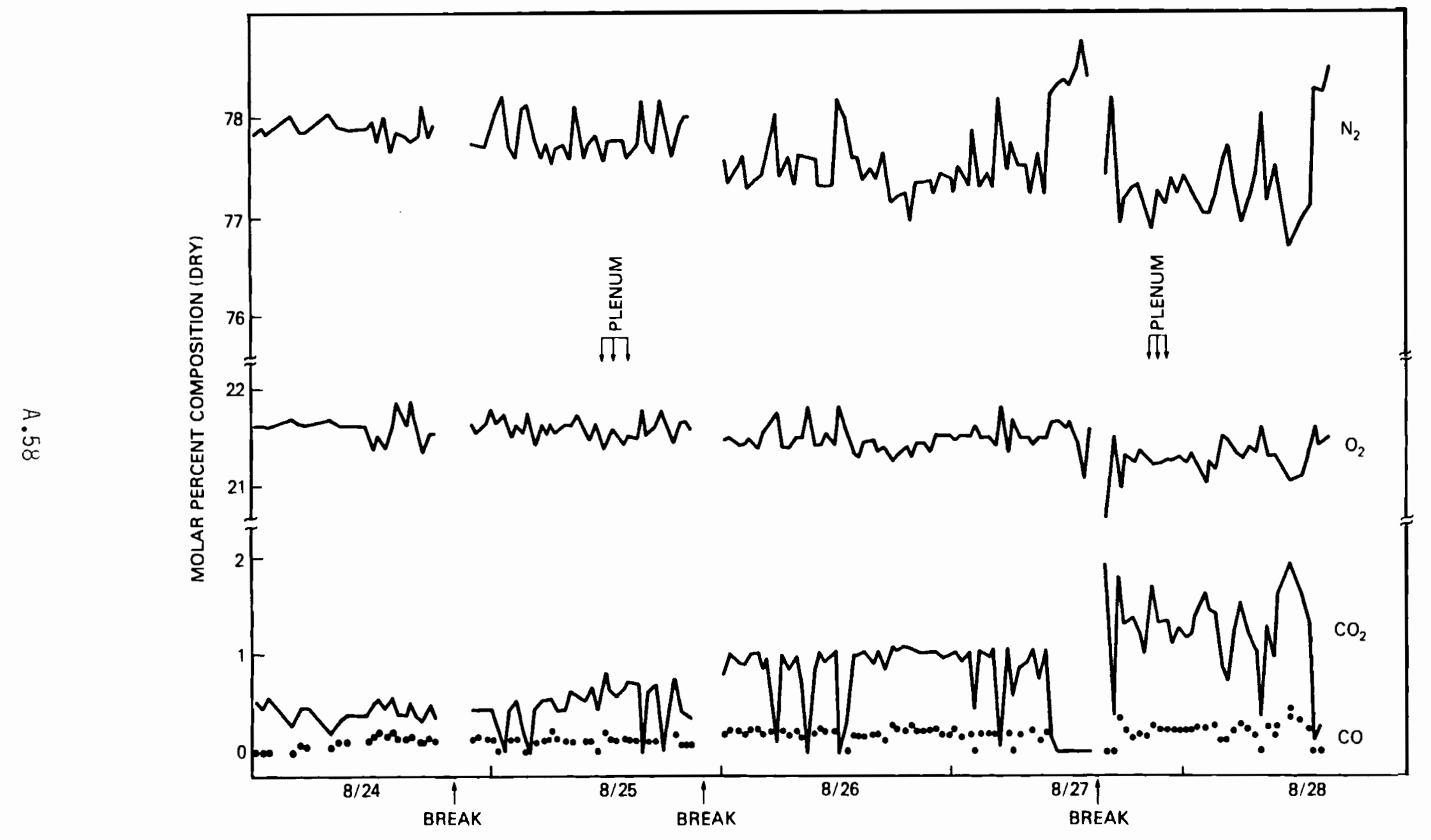

FIGURE A.65. LFCM-7 Noncondensible Off-Gas Composition 
TABLE A.33. LFCM-7 Off-Gas Composition

Molar Composition, \%

\begin{tabular}{|c|c|c|c|c|c|c|c|}
\hline \multirow[b]{2}{*}{ Day } & \multirow{2}{*}{$\begin{array}{l}\text { Data } \\
\text { Type }\end{array}$} & \multicolumn{5}{|c|}{ Dry Basis } & \multirow[b]{2}{*}{$\underline{\mathrm{H}_{2} \mathrm{O}}$} \\
\hline & & $\mathrm{CO}_{2}$ & $\mathrm{O}_{2}(\mathrm{a})$ & $\mathrm{N}_{2}$ & $\mathrm{CO}^{-}$ & $\mathrm{H}_{2}$ & \\
\hline $8 / 23$ & Avy. & 0.49 & 21.6 & 77.9 & $<20(\mathrm{~b})$ & -- & -- \\
\hline $8 / 24$ & Avy. & 0.43 & 21.6 & 77.8 & 0.12 & -- & 22 \\
\hline $8 / 25$ & Avg. & 0.47 & 21.6 & 77.9 & 0.12 & -- & 27 \\
\hline $8 / 26$ & Avg. & 0.91 & 21.4 & 77.5 & 0.18 & -- & 35 \\
\hline $8 / 27$ & Avg. & 0.87 & 21.4 & 77.6 & 0.13 & 0.44 & 41 \\
\hline $8 / 28$ & Avy. & 1.19 & 21.3 & 77.4 & 0.21 & 0.63 & 46 \\
\hline $8 / 23-28$ & $\mathrm{Hi}$ & 2.2 & 21.8 & 78.8 & 0.44 & 0.63 & 46 \\
\hline $8 / 23-28$ & Lo & 0.03 & 20.9 & 76.3 & $<1 a^{(b)}$ & 0.40 & 22 \\
\hline
\end{tabular}

(a) Includes 1\% $\mathrm{Ar}$.

(b) In ppm.

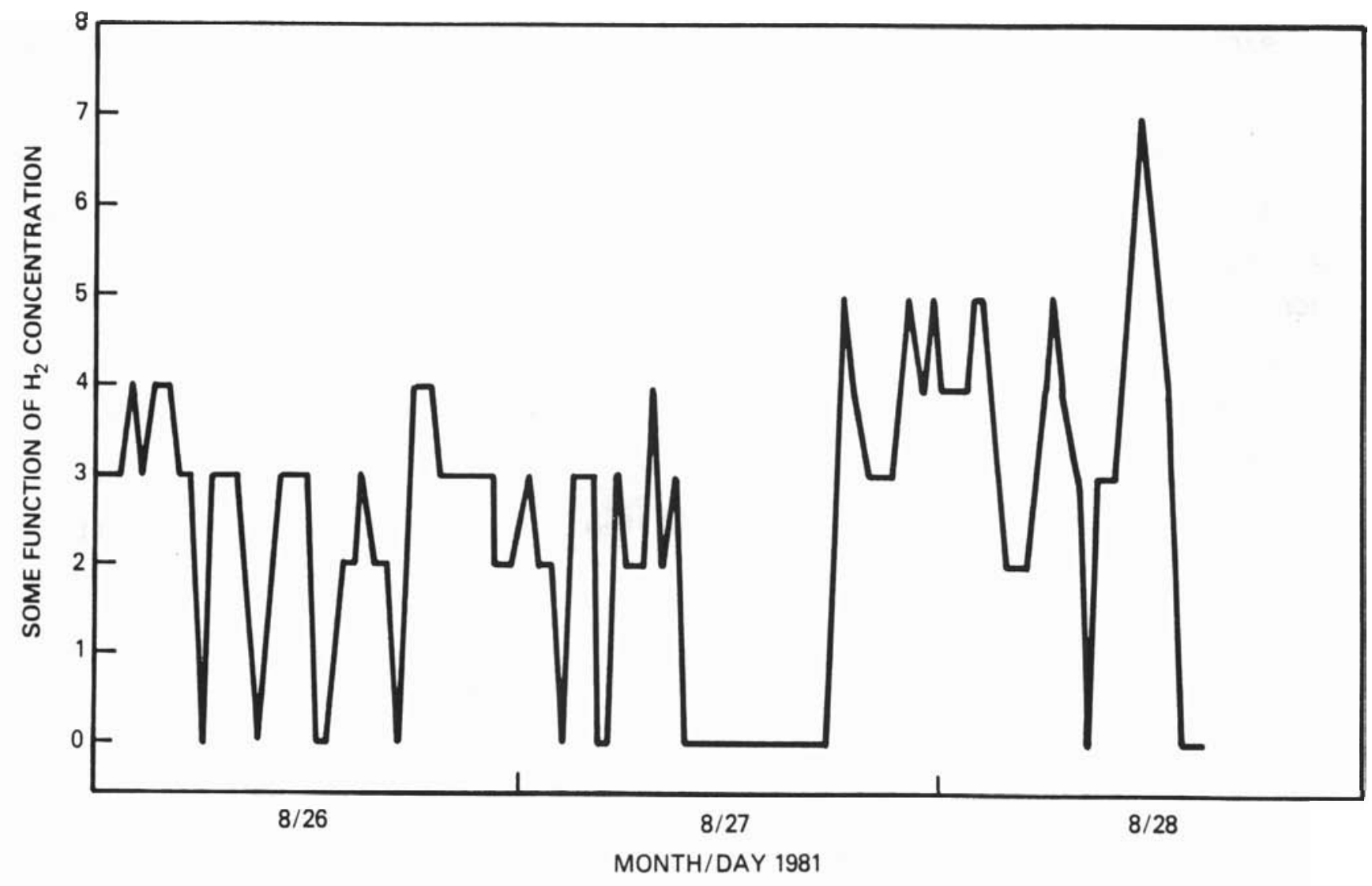

FIGURE A.66. $\mathrm{H}_{2}$ Variation Duriny LFCM-7 
PSCM-4 - DECEMBER 1981

PSCM-4 was a nonboosted, 109-h experiment designed to demonstrate a steady-state feeding capacity of $39 \mathrm{~kg} / \mathrm{h}-\mathrm{m}^{2}$. Unlike the previous LFCM-7 experiment where inleakaye rates were very high and probably a contributing factor to the high entrainment observed during that test, PSCM-4 was conducted with a newly rebuilt melter, with very low air inleakage (20 scfm). As such, the performance of this melter is most suitably comparable to the previous, unboosted PSCM-1 and PSCM-3 tests, as is clearly shown in Table A.1. The offgas-line deposits generated by the PSCM-4 melter are illustrated in Figures A.68 through A.70. The locations of these off-gas line components are illustrated in Figure A.67. A comparison of these photographs with those taken during PSCM-1 (see FY-1981 Summary) and PSCM-3 (see Section "PSCM-3, JULY 1981") reveals moderate entrainment rates associated with PSCM-4.

The magnitude of gross melter entrainment occurring during PSCM-4 was established by total HEPA filtration of the melter exhaust stream. These data appearing in Table A.34. Entrainment generated by the PSCM-4 test is greater than that observed during both the PSCM-1 and the PSCM-3 experiments.

The off gas was also sampled during PSCM-4 to establish individual melter feed component DFs. Table A.35 presents this data for all elemental feed components detected in the off-gas stream. The distribution of these effluents across sampling train components (particulate versus condensible) is also given in the table. Physically, the melter-generated effluents are predominantly particulate in nature, at least at the point at which they enter the off-gas system.

A possible exception to the above statement is the semivolatile element Ru. No airborne state or phase of this element was detected by any of the offgas sampling experiments conducted during PSCM-4 in spite of a high feed loading for this element. The most plausible explanation for this observation is that $\mathrm{Ru}$ is being reduced by the formic acid in the feed and is subsequently lost to the melter floor as slag. A surface plate-out mechanism is a possible, but less likely explanation for these losses. However, no local deposits of Ru metal have been observed in off-gas line components. 


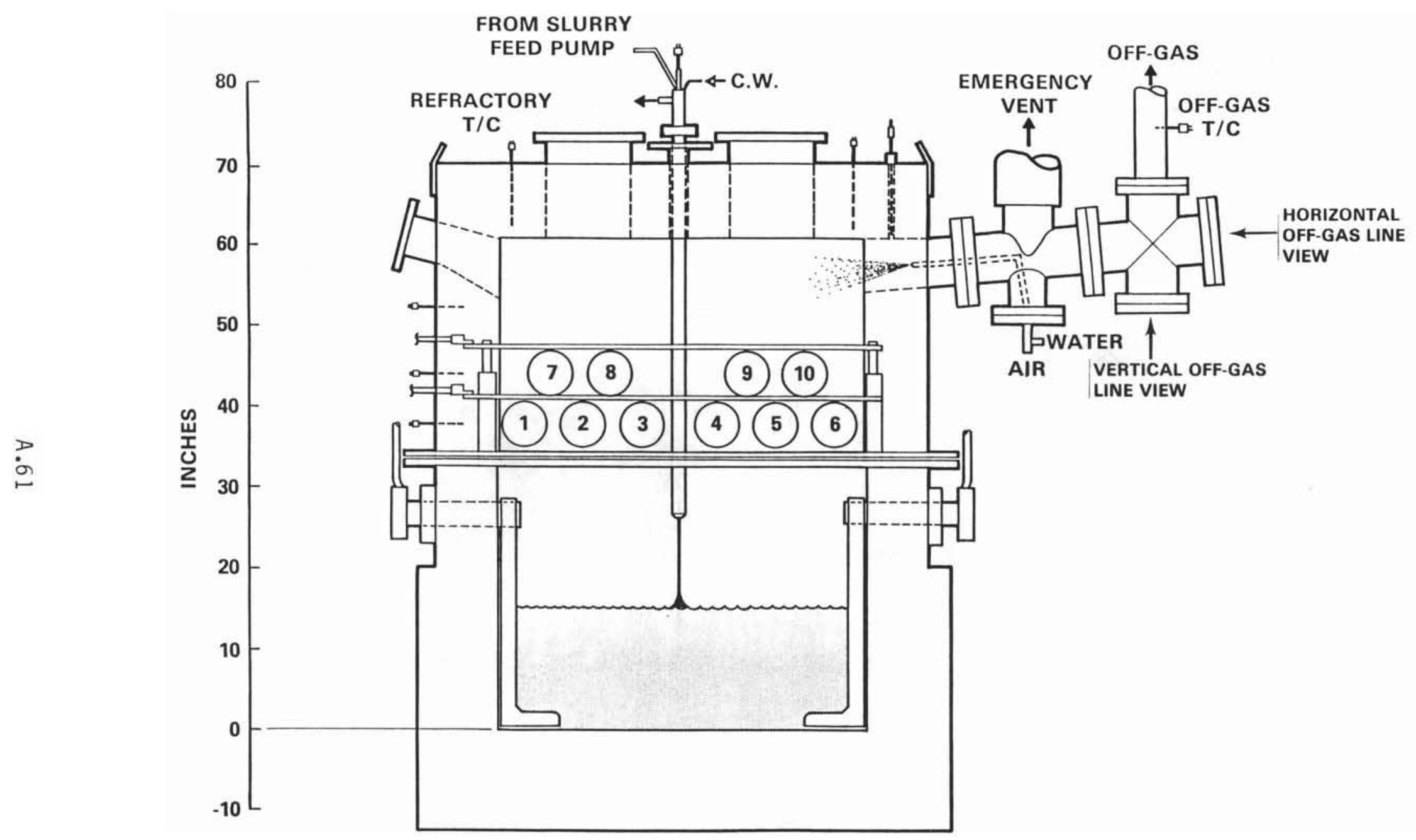

FIGURE A.67. PSCM Off-Gas-Line Configuration 


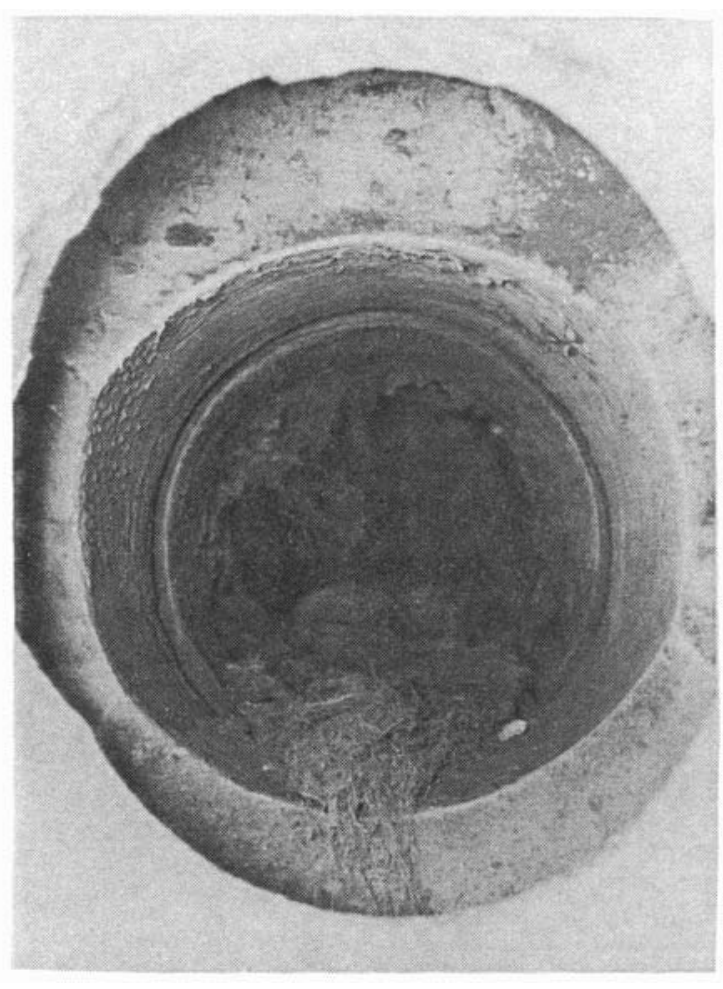

FIGURE A.68. PSCM-4 Off-Gas Line Horizontal Section

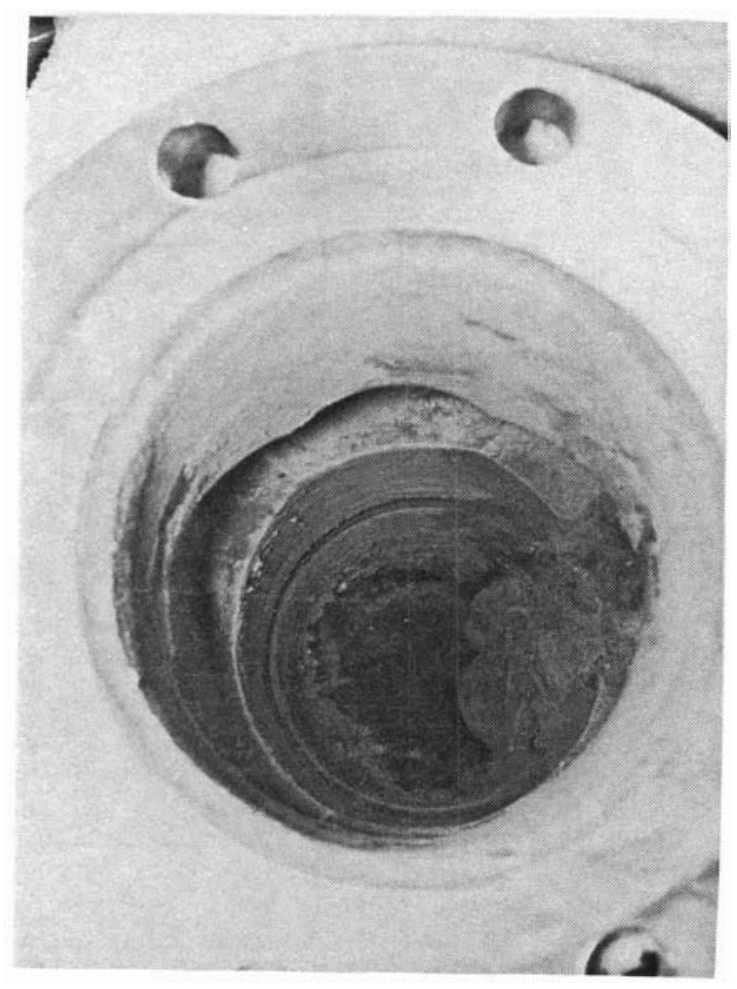

FIGURE A.69. PSCM-4 Off-Gas Line Horizontal Section

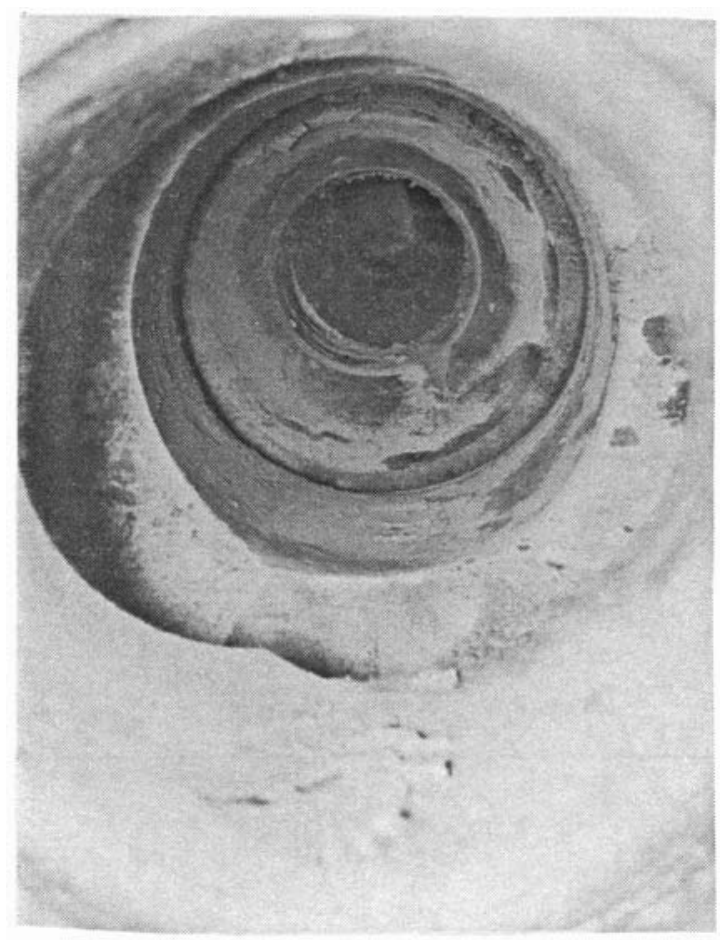

FIGURE A.70. PSCM-4 Off-Gas Line Vertical Section 
TABLE A.34. PSCM-4 Aerosol DFs

\begin{tabular}{|c|c|c|c|c|}
\hline \multicolumn{2}{|c|}{ Sampling Period } & \multirow{2}{*}{$\begin{array}{c}\text { Sarnple } \\
\text { Type }\end{array}$} & \multirow{2}{*}{$\begin{array}{c}\text { Feed Rate, } \\
\text { L/h }\end{array}$} & \\
\hline Date & Interval & & & $\mathrm{DF}$ \\
\hline $12 / 08$ & $2242-0252$ & HEPA & 62 & 516 \\
\hline $12 / 10$ & $0026-0600$ & HEPA & 62 & 500 \\
\hline $12 / 11$ & $0200-1015$ & HEPA & 67 & 509 \\
\hline
\end{tabular}

TABLE A.35. Particulate and Total Elemental Melter DFs

\begin{tabular}{|c|c|c|c|c|c|c|c|c|}
\hline \multirow[b]{3}{*}{ Element } & \multicolumn{2}{|c|}{$12 / 07 / 81$} & \multicolumn{2}{|c|}{$12 / 08 / 81$} & \multicolumn{2}{|c|}{$12 / 09 / 81$} & \multicolumn{2}{|c|}{ Average } \\
\hline & & & D & & D & & & \\
\hline & Part & Total & Part & Total & Part & Total & Part & Total \\
\hline $\mathrm{Al}$ & $1.9 \times 10^{4}$ & $1.9 \times 10^{4}$ & $2.9 \times 10^{4}$ & $2.4 \times 10^{4}$ & $3.1 \times 10^{4}$ & $2.6 \times 10^{4}$ & $2.6 \times 10^{4}$ & $2.3 \times 10^{4}$ \\
\hline B & $7.3 \times 10^{3}$ & 350 & $9.2 \times 10^{3}$ & 180 & $7.2 \times 10^{3}$ & 160 & $7.9 \times 10^{3}$ & 230 \\
\hline $\mathrm{Ca}$ & $2.1 \times 10^{3}$ & $2.0 \times 10^{3}$ & $2.4 \times 10^{3}$ & $2.2 \times 10^{3}$ & $1.7 \times 10^{3}$ & $1.4 \times 10^{3}$ & $2.1 \times 10^{3}$ & $1.9 \times 10^{3}$ \\
\hline $\mathrm{Cd}$ & 19 & 19 & 4.1 & 4.0 & 4.5 & 4.5 & 9.2 & 9.2 \\
\hline $\mathrm{Cl}$ & 13 & 9.9 & 5.1 & 3.2 & 3.0 & 2.0 & 7 & 5 \\
\hline Cs & 27 & 27 & 8.9 & 8.5 & 11 & 11 & 16 & 16 \\
\hline $\mathrm{Fe}$ & $2.7 \times 10^{3}$ & $2.7 \times 10^{3}$ & $2.4 \times 10^{3}$ & $1.8 \times 10^{3}$ & $1.8 \times 10^{3}$ & $1.6 \times 10^{3}$ & $2.3 \times 10^{3}$ & $2.0 \times 10^{3}$ \\
\hline LI & $1.6 \times 10^{3}$ & $1.6 \times 10^{3}$ & 700 & 677 & $7.6 \times 10^{3}$ & $7.2 \times 10^{3}$ & $3.3 \times 10^{3}$ & $3.2 \times 10^{3}$ \\
\hline$M n$ & $2.6 \times 10^{3}$ & $2.6 \times 10^{3}$ & $2.7 \times 10^{3}$ & $2.2 \times 10^{3}$ & $2.2 \times 10^{3}$ & $1.6 \times 10^{3}$ & $2.5 \times 10^{3}$ & $2.1 \times 10^{3}$ \\
\hline $\mathrm{Na}$ & 380 & 380 & 1.5 & 1.5 & 170 & 170 & 180 & 180 \\
\hline $\mathrm{Ni}$ & $1.9 \times 10^{3}$ & $1.8 \times 10^{3}$ & $2.3 \times 10^{3}$ & $1.2 \times 10^{3}$ & $1.8 \times 10^{3}$ & $1.3 \times 10^{3}$ & $2.0 \times 10^{3}$ & $1.4 \times 10^{3}$ \\
\hline s & 100 & 26 & 15 & 6.9 & 55 & 16 & 57 & 16 \\
\hline si & $8.2 \times 10^{3}$ & $8.1 \times 10^{3}$ & $1.4 \times 10^{4}$ & $1.2 \times 10^{4}$ & $1.1 \times 10^{4}$ & $7.6 \times 10^{3}$ & $1.1 \times 10^{4}$ & $9.2 \times 10^{3}$ \\
\hline $\mathrm{Sr}$ & -- & -- & 310 & 310 & 190 & 190 & 250 & 250 \\
\hline $\mathrm{Te}$ & 5 & 5 & 1.9 & 1.9 & 2.3 & 2.3 & 3.1 & 3.1 \\
\hline$T i$ & $8.2 \times 10^{3}$ & $8.2 \times 10^{3}$ & $1.1 \times 10^{4}$ & $1.0 \times 10^{4}$ & $7.9 \times 10^{3}$ & $7.8 \times 10^{3}$ & $9.0 \times 10^{3}$ & $8.7 \times 10^{3}$ \\
\hline $2 r$ & $4.2 \times 10^{3}$ & $4.2 \times 10^{3}$ & $6.4 \times 10^{3}$ & $6.4 \times 10^{3}$ & $4.4 \times 10^{3}$ & $4.4 \times 10^{3}$ & $5.0 \times 10^{3}$ & $5.0 \times 10^{3}$ \\
\hline
\end{tabular}

Individual melter feed component DFs observed in PSCM-4 are compared in Table A.36 with DFs collected from all previous rnelter experiments. This comparison reveals that PSCM- 4 effluent emission rates are, on the average, lower than those observed during PSCM-3, but remain higher than those associated with PSCM-1, the "cleanest" rnelter experiment conducted to date. 
TABLE A.36. PSCM-4 Comparative DFs

\begin{tabular}{|c|c|c|c|c|c|c|c|c|c|}
\hline \multirow[b]{3}{*}{ Element } & \multirow{3}{*}{$\begin{array}{l}\text { PSCM-4 } \\
\text { Avg. DF }\end{array}$} & \multicolumn{8}{|c|}{ DF Ratio } \\
\hline & & PSCALA & RSCM 4 & RSCA-4 & RSEM-4 & RSCA44 & PSCA-4 & PSCAL 4 & RSAM \\
\hline & & $\underline{\text { LFCM }-7}$ & PSCM-3 & LFCM-6 & PSOM2 & LFCM-4 & PSCM-I & LFCM-3 & LFCM-2 \\
\hline Al & $2.3 \times 10^{4}$ & 120 & 3.8 & 70 & 23 & 43 & 2.1 & 9.6 & 4.7 \\
\hline B & 230 & 3.1 & 1.2 & 2.6 & 1.4 & 1.8 & 1.1 & 1.9 & 0.89 \\
\hline $\mathrm{Ca}$ & $1.9 \times 10^{3}$ & 31 & 1.7 & 11 & 3.1 & 7.3 & 1.0 & 1.0 & 2.6 \\
\hline $\mathrm{Cd}$ & 9.2 & 1.2 & - & 0.12 & 0.20 & 0.13 & 0.05 & 0.11 & -- \\
\hline $\mathrm{Cl}$ & 5 & -- & 1.2 & 1.8 & 1.7 & 2.3 & 1.6 & 0.56 & 0.29 \\
\hline Cs & 16 & 1.3 & 4.2 & 1.6 & 5.3 & 0.28 & 0.31 & 2.3 & 0.40 \\
\hline $\mathrm{Fe}$ & $2.0 \times 10^{3}$ & 29 & 1.2 & 8.7 & 2.9 & 7.7 & 0.53 & 2.9 & 4.8 \\
\hline $\mathrm{Li}$ & $3.2 \times 10^{3}$ & 36 & 1.2 & 20 & 9.4 & 10 & 1.7 & 4.8 & 3.5 \\
\hline $\mathrm{Mn}$ & $2.1 \times 10^{3}$ & 28 & 0.64 & 6.4 & 3.3 & 5.0 & 0.37 & 0.68 & 1.3 \\
\hline $\mathrm{Na}$ & 180 & 3.0 & 0.20 & 2.0 & 1.4 & 0.53 & 0.22 & 0.64 & 0.54 \\
\hline $\mathrm{Ni}$ & $1.4 \times 10^{3}$ & -- & 0.15 & 1.5 & - & 5.4 & 0.93 & 3.3 & 3.3 \\
\hline $\mathbf{s}$ & 16 & -- & 2.0 & 1.5 & 0.84 & 16 & 16 & 3.2 & 0.84 \\
\hline Si & $9.2 \times 10^{3}$ & 77 & 3.1 & 33 & 5.8 & 22 & 0.61 & 3.5 & 9.8 \\
\hline sr & 250 & 4.6 & 0.39 & 0.86 & 0.39 & 1.2 & 0.03 & 0.17 & 0.66 \\
\hline Te & 3.1 & 0.55 & 0.10 & 0.01 & 0.05 & 0.05 & 0.02 & 0.01 & 0.05 \\
\hline $\mathrm{Ti}$ & $8.7 \times 10^{3}$ & 72 & 2.1 & 51 & 6.2 & - & -- & - & 7.9 \\
\hline $\mathrm{Zr}$ & $5 \times 10^{3}$ & - & - & -- & -- & -- & -- & -- & -- \\
\hline
\end{tabular}

Total aerosol DFs were also extracted from the data presented in

Table A.35. These values, combined with the HEPA data previously discussed, are summarized in Table A.37. Overall, the entrainment DF values were fairly consistent throughout the run, with an average value of 630 . This is lower than the values from both the PSCM-1 and PSCM-3 experiments, but is still quite respectable.

The size distribution of particulate matter conveyed to the off-gas system by the unboosted PSCM-4 melter was also investigated during this test by a four-stage cyclonic particle-size separator having $16 \mu \mathrm{m}, 6 \mu \mathrm{m}, 1 \mu \mathrm{m}$ and $<1 \mu \mathrm{m}$ cut points. The results of this study are summarized in Table A.38. Unlike the previous LFCM- 7 experiment where $>80 \%$ of the melter entrained mass was 
TABLE A.37. PSCM-4 Gross Aerosol DFs

\begin{tabular}{|c|c|c|c|c|}
\hline$\frac{\text { Sampling }}{\text { Date }}$ & $\frac{\text { Period }}{\operatorname{lnterval}}$ & $\begin{array}{l}\text { Feed Rate, } \\
\text { Sample Type }\end{array}$ & $L / h$ & DF \\
\hline $12 / 07$ & $\overline{1715-2018}$ & $\overline{S-F I L T E R}(a)$ & 52 & $\overline{970}$ \\
\hline $12 / 08$ & $1848-2218$ & S - FILTER & 60 & 460 \\
\hline $12 / 8-9$ & $2241-0252$ & HEPA & 62 & 520 \\
\hline $12 / 09$ & $1650-2302$ & $S-$ FILTER & 63 & 470 \\
\hline $12 / 10$ & $0026-0600$ & ЮEPA & 62 & 500 \\
\hline $12 / 10$ & $1720-2306$ & $S-$ FILTER & 66 & 980 \\
\hline $12 / 11$ & $0200-1015$ & HEPA & 67 & $\underline{510}$ \\
\hline $12 / 07-11$ & Average & ALL & & 630 \\
\hline
\end{tabular}

(a) Sample stream filter.

TABLE A.38. PSCM-4 Particulate Size Data

\begin{tabular}{|c|c|c|c|c|c|}
\hline \multicolumn{2}{|c|}{ Sampliny Period } & \multicolumn{4}{|c|}{ Wt\% Versus Cut Point } \\
\hline$\overline{D a t e}$ & Interval & $16 \mu \mathrm{m}$ & $6 \mu \mathrm{m}$ & $1 \mu \mathrm{m}$ & $\leq 1 \mu \mathrm{m}$ \\
\hline $12 / 07$ & $1811-1901$ & 0 & 3.4 & 4.7 & 91.9 \\
\hline $12 / 08$ & $2202-2212$ & 0 & 0 & 0 & 100.0 \\
\hline $12 / 09$ & $1712-1720$ & 0 & 0 & 9.6 & 90.4 \\
\hline $12 / 10$ & $1950-1959$ & 卫 & 0 & $\underline{0}$ & 100.0 \\
\hline & Average & 0 & 0.9 & 3.6 & 95.6 \\
\hline
\end{tabular}

collected by the $16 \mu \mathrm{m}$ cyclone, PSCM-4 emitted predominantly submicron aerosols. The composition of PSCM-4 submicron particulate matter is presented in Table A.39. As was the case during LFCM-7, the submicron melter-generated aerosol was highly enriched with semivolatile elements relative to the feed. If a material balance is conducted for this submicron matter by assuming an oxide form for all elements except for a stoichiometric quantity of $\mathrm{Na}$, which is associated with the $\mathrm{Cl}$ in the sample, $98.8 \%$ of the matter present can be accounted for. It should be noted that the submicron particulate sample is $83 \%$ $\mathrm{NaCl}$.

The noncondensible composition of the melter exhaust was determined by a GC at 30 -min intervals throughout the duration of PSCM-4. The percentages of 
TABLE A.39. PSCM-4 Submicron Particulate Composition

\begin{tabular}{|c|c|c|c|c|}
\hline El ement & $\begin{array}{c}\text { Elemental } \\
W t \%\end{array}$ & $\begin{array}{l}\text { Elemental } \\
\text { Form } \\
\end{array}$ & $\begin{array}{c}\text { Compound } \\
W t \%\end{array}$ & $\begin{array}{c}\text { Feed } \\
\text { Composition, \% } \\
\end{array}$ \\
\hline Al & 0.04 & $\mathrm{Al}_{2} \mathrm{O}_{3}$ & 0.08 & 4.95 \\
\hline B & 0.07 & $\mathrm{~B}_{2} \mathrm{O}_{3}$ & 0.24 & 9.86 \\
\hline $\mathrm{Ca}$ & 0.14 & $\mathrm{CaO}$ & 0.20 & 1.66 \\
\hline $\mathrm{Cd}$ & 0.55 & $\mathrm{cdO}$ & 0.63 & 0.006 \\
\hline $\mathrm{Cl}$ & 55.0 & -- & -- & 0.4 \\
\hline Cs & 2.1 & $\mathrm{Cs}_{2} \mathrm{O}$ & 2.2 & 0.044 \\
\hline $\mathrm{Cu}$ & 0.06 & $\mathrm{CuO}$ & 0.09 & -- \\
\hline $\mathrm{Fe}$ & 0.29 & $\mathrm{Fe}_{2} \mathrm{O}_{3}$ & 0.41 & 13.69 \\
\hline k & 0.36 & $\mathrm{~K}_{2} \mathrm{O}$ & 0.43 & -- \\
\hline Li & 1.1 & $\mathrm{Li}_{2} \mathrm{O}$ & 2.4 & 3.98 \\
\hline Mg & 0.02 & $\mathrm{MgO}$ & 0.03 & 1.29 \\
\hline Mn & 0.08 & $\mathrm{MnO}_{2}$ & 0.13 & 3.25 \\
\hline $\mathrm{Na}$ & 33.7 & $\begin{array}{l}\mathrm{NaCl} \\
\mathrm{Na}_{2} \mathrm{O}\end{array}$ & $\begin{array}{r}83.0 \\
6.7\end{array}$ & $\overline{13.88}$ \\
\hline $\mathrm{Ni}$ & 0.03 & NiO & 0.04 & 0.76 \\
\hline $\mathrm{Pb}$ & 0.04 & PbO & 0.05 & -- \\
\hline Si & 0.66 & $\mathrm{SiO}_{2}$ & 1.4 & 44.47 \\
\hline $\mathrm{Te}$ & 0.56 & $\mathrm{TeO}_{2}$ & 0.71 & 0.006 \\
\hline $2 n$ & 0.02 & $\mathrm{ZnO}$ & 0.02 & -- \\
\hline Total & & & 98.8 & \\
\hline
\end{tabular}

$\mathrm{N}_{2}, \mathrm{O}_{2}+\mathrm{Ar}, \mathrm{CO}, \mathrm{CO}_{2}$ and $\mathrm{H}_{2}$ are plotted in Figure A.71. The $\mathrm{H}_{2}$ data presented in Figure $A .71$ is included to illustrate $\mathrm{H}_{2}$ concentration trends only. The GC response function for this molecule has not been determined. A summary of offgas composition is presented in Table A.40.

Off-gas concentrations of $\mathrm{SU}_{2}$ were also continuously measured during part of PSCM-4 (see Figure A.71 and Table A.40). Table A.41 compares the $\mathrm{SO}_{2}$ offgas monitoring data with average $\mathrm{SO}_{2}$ values derived from off-gas scrubbing data. The low values obtained from the $\mathrm{SO}_{2}$ monitor resulted from the unavoidable interaction of this gas with condensed-phase $\mathrm{H}_{2} \mathrm{O}$ and/or the presence of $\mathrm{SO}_{3}$. 

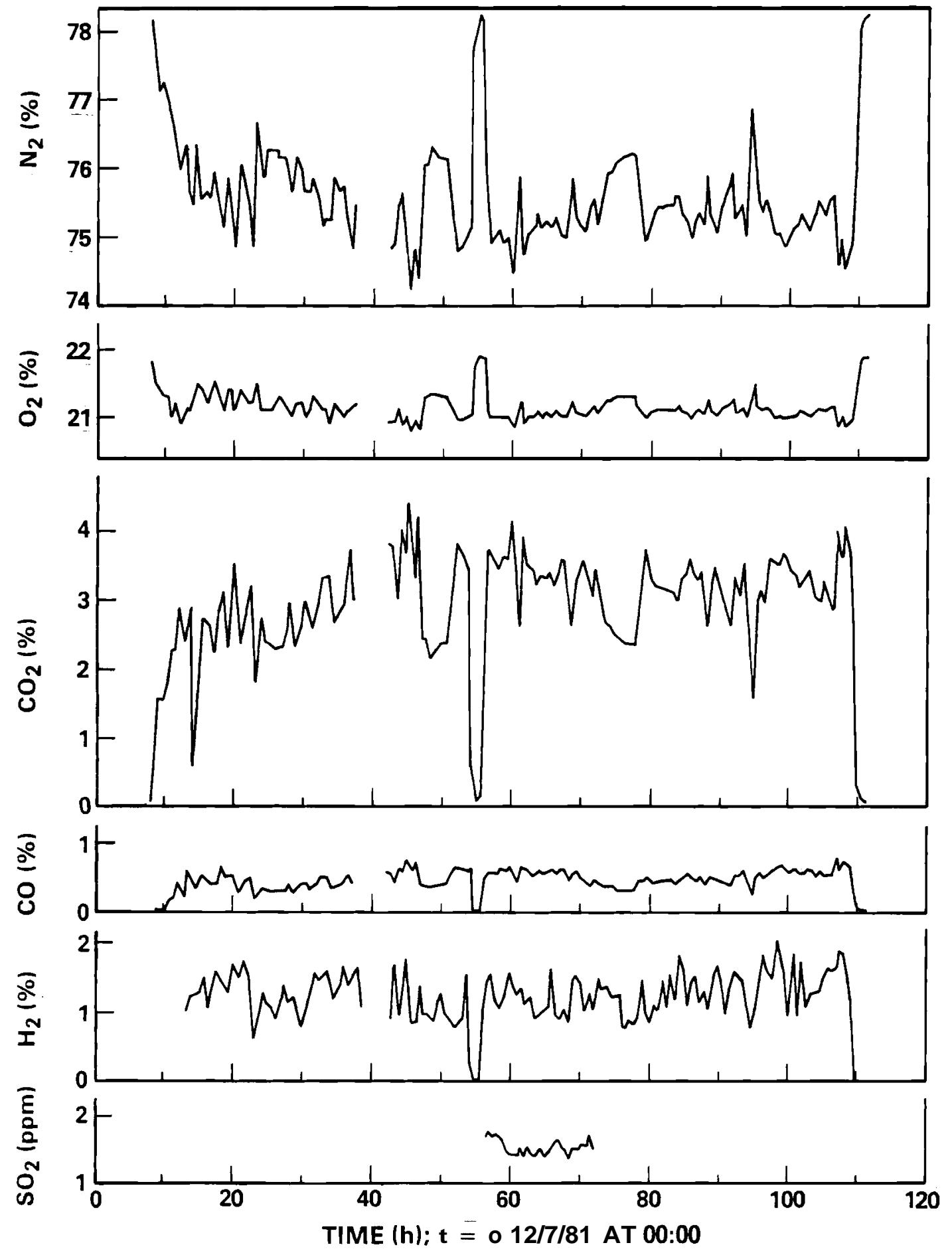

FIGURE A.7 1. PSCM-4 Off-Gas Cornposition 
TABLE A.40. PSCM-4 Noncondensible Off-Gas Composition

\begin{tabular}{|c|c|c|c|c|c|c|c|c|}
\hline \multirow[b]{3}{*}{ Date } & \multirow{3}{*}{$\begin{array}{l}\text { Data } \\
\text { Type }\end{array}$} & \multicolumn{7}{|c|}{ Molar Composition, \% } \\
\hline & & & & $\mathrm{Dr}$ & 3asis & & & \\
\hline & & $\mathrm{CO}_{2}$ & $\mathrm{O}_{2}(\mathrm{a})$ & $\mathrm{N}_{2}$ & $\mathrm{CO}$ & $\mathrm{H}_{2}$ & $\mathrm{SO}_{2} \mathrm{ppm}$ & $\mathrm{H}_{2} \mathrm{O}$ \\
\hline $12 / 07$ & Avg. & 2.5 & 20.9 & 76.3 & 0.37 & -- & - & 77.0 \\
\hline $12 / 08$ & Avg. & 3.0 & 20.7 & 75.8 & 0.43 & -- & -- & 80.5 \\
\hline $12 / 09$ & Avy. & 3.0 & 20.7 & 75.8 & 0.48 & 1.3 & 1.5 & 78.6 \\
\hline $12 / 10$ & Avg. & 3.0 & 20.8 & 75.8 & 0.42 & -- & $>2.0$ & 81.1 \\
\hline $12 / 11$ & Avg. & 3.0 & 20.7 & 75.8 & 0.49 & 1.0 & $>2.0$ & -- \\
\hline $12 / 7-11$ & $\mathrm{Hi}$ & 4.4 & 21.0 & 77.1 & 0.75 & 1.3 & $>2.0$ & 81.1 \\
\hline $12 / 7-11$ & Lo & 0.5 & 20.4 & 74.5 & 0.20 & 1.0 & 1.34 & 77.0 \\
\hline
\end{tabular}

(a) Includes $-1 \%$ Ar.

TABLE A.41. PSCM-4 $\mathrm{SO}_{2} \mathrm{Off}-\mathrm{Gas}$ Concentration

\begin{tabular}{lcccc}
\multicolumn{2}{c}{ Sampliny Period } & & \multicolumn{3}{c}{ Concentration, ppm (V1/V1) } \\
\cline { 1 - 2 }$\frac{\text { Date }}{12 / 07}$ & $\frac{\text { Interval }}{1715-2018}$ & & 1.8 & -- \\
$12 / 08$ & $1848-2218$ & & 7.6 & -- \\
$12 / 09$ & $1650-2320$ & & 12.0 & 1.5 (Avg.) \\
$12 / 10$ & $1720-2306$ & & 23.0 & $>2.0$ \\
$12 / 11$ & $0800-1300$ & & -- & $>2.0$
\end{tabular}

During the PSCM-4 run, samples were taken of the scrubbing solution from the venturi scrubber and the packed tower. The analyses of the solutions were used to calculate a melter DF and a venturi DF. These results are based on the assumption that the venturi scrubber and the packed tower collected greater than $99 \%$ of the material leaving the melter, and that the venturi scrubbing solution had reached steady state. PSCM-4 was a smooth, steady run, so the steady-state assumption should be good.

The results of the analysis are shown in Table A.42. Calcium was left out of the analysis because of large amounts added to the venturi scrub solution to neutralize the condensate and retard corrosion. The total oxide DF compared very well with values reported for the HEPA filters (500 average). 
TABLE A.42. Melter Decontamination Factors

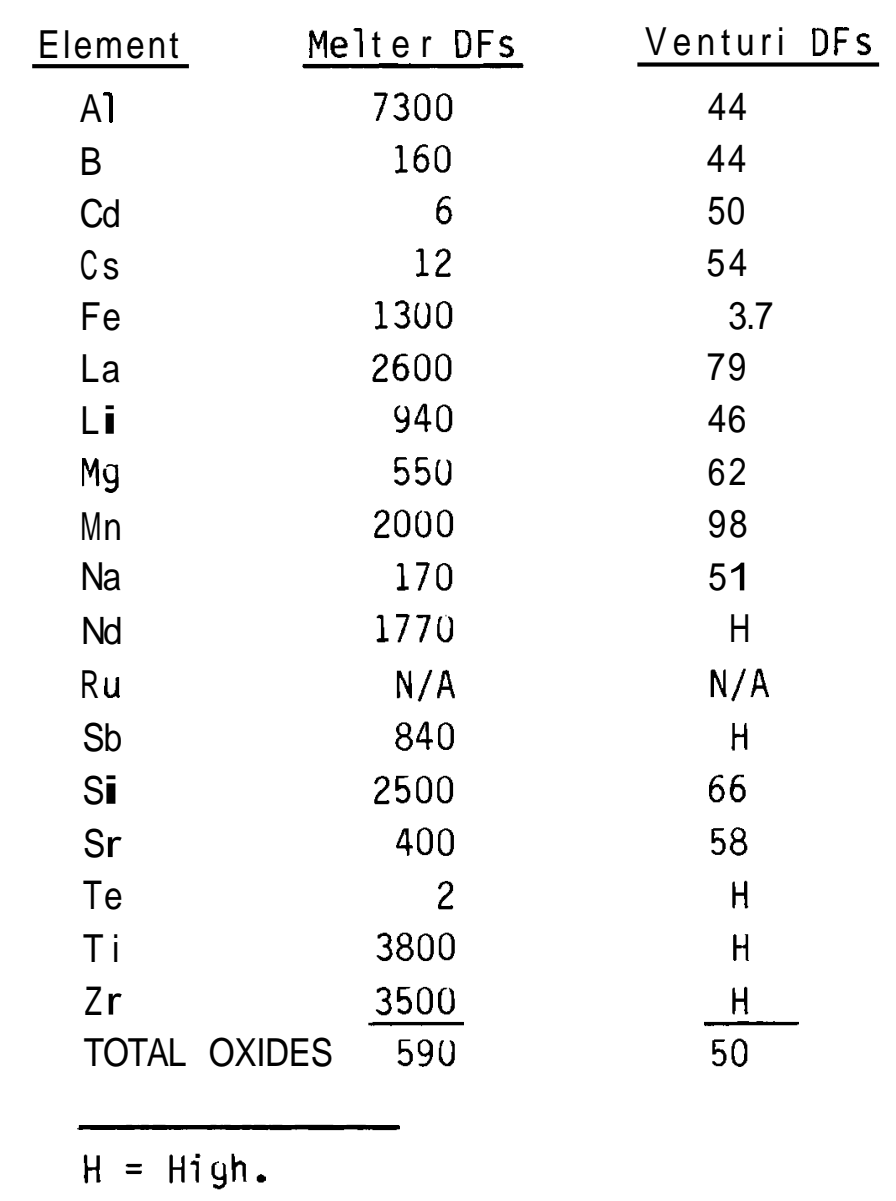

PSCM-5 - FEBRUARY 1982

PSCM-5 was a 99-h experiment designed to characterize maximum feeding rates achievable utilizing electric lid heat boosting. As such, it represents the second boosted experiment utilizing the new formate feed composition. As revealed in Section "LFCM-7, AUGUST 1981," the first boosted test (LFCM-7) with the formate-feed formulation exhibited melter DFs, which were generally the lowest ever recorded. Consequently, the effluent behavior associated with this experiment was of keen interest.

The off-yas lines of the pilot-scale melter were visually examined upon completion of the PSCM-5 test. Melter depositions were greatest around off-gas line penetrations, which tended to collect glass strands and other debris. Overall, the conditions of the melter off-yas lines were quite similar to what 
was found at the conclusion of the previous melter test (PSCM-4). The largest accumulation of melter debris developed around the off-gas line spray nozzle, which is located at the plenum exhaust port. These deposits did not significantly restrict off-gas flow, but would present a problem under prolonged continuous melter operation.

The extent of gross melter aerosol emission was established during PSCM-5 through HEPA filtration of the entire melter exhaust stream. The results obtained from these filtration studies are summarized in Table A.43.

Although the data available are limited, the average DF value $(-500)$ extracted from this filtration study is basically the same as was obtained during the unboosted PSCM-4 test.

Particulate and total feed component DFs were also measured during PSCM-5 and are summarized in Table A.44. It is clear from this and the previous studies that, apart from the mechanisms responsible for producing airborne effluents, particulate transport through the off-gas system is the predominant loss mechanism associated with liquid-fed melter operation. This is apparently not true, however, for Ru. Again, as in PSCM-4, no airborne Ru was detected in PSCM-5 melter exhaust, even though feed and glass analyses indicate significant $\mathrm{Ru}$ melter losses. No specific sink for the element has yet been conclusively identified to account for these losses.

Table A.45 compares PSCM-5 melter feed component DFs with those measured during all previous melter tests. PSCM-5 exhibited greater overall effluent emission rates than did the unboosted PSCM-4 test. However, much higher feed component DFS were achieved during PSCM-5 than were recorded during the previous boosted LFCM-7 test, which also employed a formate-based feed.

TABLE A.43. PSCM-5 Gross Melter Entrainment

\begin{tabular}{lrlrl}
\multicolumn{2}{c}{ Sampling Period } & & \multicolumn{2}{c}{ Melter Entrainment } \\
$1 / 27$ & $\frac{1 \text { Interval }}{1820-2135}$ & & $\frac{\% \text { Loss }}{0.27}$ & $\frac{\text { DF }}{370}$ \\
$1 / 28$ & $1920-2400$ & & 0.15 & 670
\end{tabular}


TABLE A.44. PSCM-5 Particulate and Total Feed Component DFs

\begin{tabular}{|c|c|c|c|c|c|c|c|c|}
\hline \multirow[b]{3}{*}{ Element } & \multicolumn{8}{|c|}{ DF } \\
\hline & \multicolumn{2}{|c|}{$1 / 26 / 82$} & \multicolumn{2}{|c|}{$1 / 27 / 82$} & \multicolumn{2}{|c|}{$1 / 28 / 82$} & \multicolumn{2}{|c|}{ Average } \\
\hline & Part & Total & Part & Total & Part & Total & Part & Total \\
\hline Al & $1.5 \times 10^{4}$ & $1.4 \times 10^{4}$ & $1.4 \times 10^{4}$ & $1.3 \times 10^{4}$ & $1.4 \times 10^{4}$ & $1.4 \times 10^{4}$ & $1.4 \times 10^{4}$ & $1.4 \times 10^{4}$ \\
\hline B & $3.9 \times 10^{3}$ & 130 & $4.3 \times 10^{3}$ & 160 & $3.9 \times 10^{3}$ & 120 & $4.0 \times 10^{3}$ & 140 \\
\hline $\mathrm{Ca}$ & 880 & 860 & $1.1 \times 10^{3}$ & $1.1 \times 10^{3}$ & $1.2 \times 10^{3}$ & $1.2 \times 10^{3}$ & $1.1 \times 10^{3}$ & $1.1 \times 10^{3}$ \\
\hline $\mathrm{Cd}$ & 6.0 & 5.9 & 5.7 & 5.7 & 5.4 & 5.4 & 5.7 & 5.7 \\
\hline $\mathrm{Cl}$ & 3.8 & 1.8 & 3.2 & 1.5 & 3.2 & 1.1 & 3.4 & 1.5 \\
\hline Cs & 8.8 & 8.8 & 10 & 10 & 9.5 & 9.5 & 9.4 & 9.4 \\
\hline$F_{\theta}$ & $1.5 \times 10^{3}$ & $1.3 \times 10^{3}$ & $1.3 \times 10^{3}$ & $1.0 \times 10^{3}$ & $1.4 \times 10^{3}$ & $1.0 \times 10^{3}$ & $1.4 \times 10^{3}$ & $1.1 \times 10^{3}$ \\
\hline La & $7.0 \times 10^{3}$ & $7.0 \times 10^{3}$ & $8.1 \times 10^{3}$ & $8.1 \times 10^{3}$ & $1.6 \times 10^{4}$ & $1.6 \times 10^{4}$ & $1 \times 10^{4}$ & $1.0 \times 10^{4}$ \\
\hline Li & 640 & 640 & 830 & 830 & 730 & 730 & 730 & 730 \\
\hline $\mathrm{Mg}$ & $2.9 \times 10^{3}$ & $2.9 \times 10^{3}$ & $3.7 \times 10^{3}$ & $3.7 \times 10^{3}$ & $3.8 \times 10^{3}$ & $3.8 \times 10^{3}$ & $3.5 \times 10^{3}$ & $3.5 \times 10^{3}$ \\
\hline Mn & $8.5 \times 10^{3}$ & $7.5 \times 10^{3}$ & $9.2 \times 10^{3}$ & $6.3 \times 10^{3}$ & $1.0 \times 10^{4}$ & $7.6 \times 10^{3}$ & $6.2 \times 10^{3}$ & $7.1 \times 10^{3}$ \\
\hline $\mathrm{Na}$ & 150 & 150 & 170 & 170 & 150 & 150 & 160 & 160 \\
\hline Nd & 6.8 & 6.8 & -- & -- & - & -- & -- & -- \\
\hline $\mathrm{Ni}$ & $1.1 \times 10^{3}$ & 640 & $1.1 \times 10^{3}$ & 500 & $1.1 \times 10^{3}$ & 590 & $1.1 \times 10^{3}$ & 580 \\
\hline$s$ & 11 & 2.8 & 28 & 5.6 & 26 & 5.2 & 22 & 4.5 \\
\hline $\mathrm{Sb}$ & 580 & 350 & 720 & 720 & 330 & 340 & 540 & 440 \\
\hline Se & -- & -- & 110 & 110 & 140 & 140 & 130 & 130 \\
\hline $\mathrm{si}$ & $5.5 \times 10^{3}$ & $4.8 \times 10^{3}$ & $5.7 \times 10^{3}$ & $5.4 \times 10^{3}$ & $6.3 \times 10^{3}$ & $5.6 \times 10^{3}$ & $5.8 \times 10^{3}$ & $5.3 \times 10^{3}$ \\
\hline $\mathrm{Te}$ & 2.2 & 2.2 & 2.8 & 2.8 & 4.40 & 4.40 & 3.1 & 3.1 \\
\hline$T i$ & $7.6 \times 10^{3}$ & $7.6 \times 10^{3}$ & -- & -- & $6.8 \times 10^{3}$ & $6.8 \times 10^{3}$ & $7.2 \times 10^{3}$ & $7.2 \times 10^{3}$ \\
\hline $\mathrm{Zr}$ & $1.2 \times 10^{4}$ & $1.2 \times 10^{4}$ & -- & - & $1.4 \times 10^{4}$ & $1.4 \times 10^{4}$ & $1.3 \times 10^{4}$ & $1.3 \times 10^{4}$ \\
\hline
\end{tabular}

Particle size analysis of melter-entrained aerosols was conducted during PSCM-5 using a cyclonic separator system. Table A.46 summarizes the distribution of the melter-generated aerosols through the four stages of this differential particle-size analyzer. Unlike PSCM-4, which produced predominantly subrnicron aerosols, the boosted PSCM- 5 melter exhibited a bimodal particle distribution much like that observed in the boosted LFCM-7 test. However, the full distribution associated with PSCM-5 was weighted much more heavily toward the submicron region than was LFCM-7s. 
TABLE A.45. PSCM-5 Comparative DFs

\begin{tabular}{|c|c|c|c|c|c|c|c|c|c|c|}
\hline \multirow[b]{2}{*}{ El ement } & \multirow[b]{2}{*}{ PSCM-5 } & \multicolumn{9}{|c|}{ DF Ratio } \\
\hline & & $\begin{array}{l}\text { PSCM - - } \\
\text { PSCM4 } \\
\end{array}$ & $\begin{array}{l}\text { RSCA45 } \\
\text { LFCM77 }\end{array}$ & $\begin{array}{l}\text { PSCM-5 } \\
\text { PSCM-3 }\end{array}$ & $\begin{array}{l}\text { PSCA45 } \\
\text { LFCM-6 }\end{array}$ & $\begin{array}{l}\text { PSCM-5 } \\
\text { PSCM-2 }\end{array}$ & $\begin{array}{l}\text { RSCA45 } \\
\text { LFCM-4 }\end{array}$ & $\begin{array}{l}\text { PSCM-5 } \\
\text { PSCM-I }\end{array}$ & $\begin{array}{l}\text { PSCM-5 } \\
\text { LFCM-3 }\end{array}$ & $\begin{array}{l}\text { PSCM-5 } \\
\text { LFCM-2 }\end{array}$ \\
\hline $\mathrm{Al}$ & $1.4 \times 10^{4}$ & 0.61 & 74.0 & 2.3 & 42.0 & 14.0 & 26.0 & 1.3 & 5.8 & 2.8 \\
\hline B & 140 & 0.61 & 1.9 & 0.70 & 1.6 & 0.88 & 1.1 & 0.67 & 1.2 & 0.54 \\
\hline $\mathrm{Ca}$ & $1.1 \times 10^{3}$ & 0.58 & 18.0 & 1.0 & 6.1 & 1.8 & 4.2 & 0.60 & 0.59 & 1.5 \\
\hline $\mathrm{Cd}$ & 5.7 & 0.62 & 0.71 & -- & 0.07 & 0.12 & 0.08 & 0.03 & 0.07 & -- \\
\hline $\mathrm{Cl}$ & 1.5 & 0.30 & - & 0.38 & 0.56 & 0.50 & 0.68 & 0.48 & 0.17 & 0.09 \\
\hline Cs & 9.4 & 0.59 & 0.78 & 2.5 & 0.94 & 3.1 & 0.16 & 0.18 & 1.3 & 0.24 \\
\hline $\mathrm{Fe}$ & $1.1 \times 10^{3}$ & 0.55 & 16.0 & 0.69 & 4.8 & 1.6 & 4.2 & 0.29 & 1.6 & 2.6 \\
\hline La & $1 \times 10^{4}$ & -- & -- & -- & - & - & - & - & - & -- \\
\hline LI & 730 & 0.23 & 8.2 & 0.28 & 4.6 & 2.2 & 2.4 & 0.38 & 1.1 & 0.79 \\
\hline $\mathrm{Mg}$ & $3.5 \times 10^{3}$ & -- & 29.0 & 0.43 & 13.0 & 3.8 & 10.0 & 0.39 & 1.9 & 7.2 \\
\hline$M n$ & $7.1 \times 10^{3}$ & 3.4 & 93.0 & 2.2 & 22.0 & 11.0 & 17.0 & 1.2 & 2.3 & 4.5 \\
\hline $\mathrm{Na}$ & 160 & 0.89 & 2.7 & 0.18 & 1.8 & 1.2 & 0.47 & 0.19 & 0.57 & 0.48 \\
\hline $\mathrm{Ni}$ & 580 & 0.41 & -- & 0.06 & 0.62 & -- & 2.2 & 0.39 & 1.4 & 1.4 \\
\hline $\mathrm{s}$ & 4.5 & 0.28 & - & 0.56 & 0.41 & 0.24 & 4.50 & 4.50 & 0.90 & 0.24 \\
\hline Sb & 440 & -- & 6.6 & - & -- & 4.4 & 0.24 & -- & -- & 0.91 \\
\hline Se & 130 & - & - & -- & - & $\cdots$ & -- & -- & -- & -- \\
\hline si & $5.3 \times 10^{3}$ & 0.58 & 44.0 & 1.8 & 19.0 & 3.3 & 13.0 & 0.35 & 2.0 & 5.6 \\
\hline $\mathrm{Te}$ & 3.1 & 1.0 & 0.55 & 0.10 & 0.01 & 0.05 & 0.05 & 0.02 & 0.01 & 0.05 \\
\hline $\mathrm{TI}$ & $72 \times 10^{3}$ & 0.83 & 60.0 & 1.8 & 42.0 & 5.1 & -- & -- & -- & 6.6 \\
\hline $\mathrm{Zr}$ & $1.3 \times 10^{4}$ & 2.6 & - & -- & - & -- & -- & -- & - & -- \\
\hline
\end{tabular}

TABLE A.46. PSCM-5 Differential Particulate Data

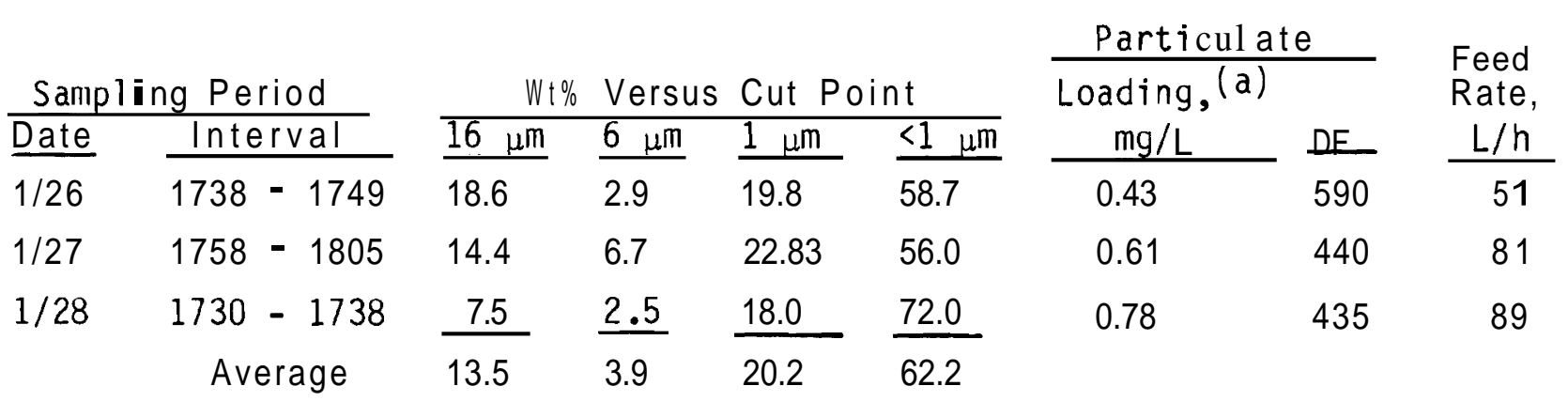

(a) STP. 
The compositions of the various cyclonic particulate size fractions were analyzed to establish the nature of semivolatile melter emissions. The resultant data appearing in Table A.47 suggest that most of the effluent mass associated with the radiologically important semivolatiles is conveyed to the melter off-gas system as submicron particulate matter.

Gross melter aerosol emissions can be characterized from most of the sampling data which has already been presented. Table A.48 summarizes all gross particulate melter DF values derived from these data. Comparison of this data with corresponding results from the nonboosted PSCM-4 experiment reveal only a slight increase in effective melter entrainment associated with the present test. Based upon past LFCM experiments, it is surprising that the lid heat boosting associated with PSCM-5 did not have a more pronounced effect upon melter entrainment.

Noncondensible melter off-yas data was collected during this experiment usiny a GC (analyzing for $\mathrm{O}_{2}, \mathrm{~N}_{2}, \mathrm{CO}$ and $\mathrm{CO}_{2}$ ) as well as continuous gas monitors (analyzing for $\mathrm{H}_{2}, \mathrm{O}_{2}, \mathrm{CO}$ and $\mathrm{CO}_{2}$ ). The $\mathrm{GC}$ data is displayed in Figure A.72. Fiyure A.73 is a plot of the continuous data taken at 15-min intervals, which provides a hiyher resolution study of $\mathrm{H}_{2}, \mathrm{O}_{2}, \mathrm{CO}$ and $\mathrm{CO}_{2}$ than is afforded by the GC. Baseline drifts were observed in both $\mathrm{O}_{2}$ and $\mathrm{H}_{2}$ data. The oxygen data was corrected by approximating the nonlinear drift by a series of linear segments (a piecewise linear relationship). The $\mathrm{H}_{2} \mathrm{drift}$, which amounted to $0.25 \% \mathrm{H}_{2}$ at the end of the run, was probably due to gradual changes in the dewpoint of the sample stream and was not corrected. The discontinuities present in these data plots are produced by instrument calibrations. Table A.49 summarizes all the noncondensible off-gas compositional data taken during PSCM-5.

Off-yas deposits were taken from the off-gas lines and viewports after PSCM-5. The results are shown in Table A.50. The results are similar to each other and to past runs, which have shown off-gas-line deposits enriched in $\mathrm{Cl}$, Cs, $\mathrm{Na}, \mathrm{S}, \mathrm{Te}, \mathrm{Cd}$, and $\mathrm{Ru}$. 
TABLE A.47. Elemental Distribution Across Cyclonic Aerosol Size Fractions

\begin{tabular}{|c|c|c|c|c|c|c|c|c|}
\hline \multirow[b]{3}{*}{ Element } & \multicolumn{8}{|c|}{ Elemental Distribution, \% } \\
\hline & & Fract & n $1 / 26$ & & & Frac & n $1 / 28$ & \\
\hline & $16 \mu \mathrm{m}$ & $6 \mu \mathrm{m}$ & $1 \mu m$ & $<1 \mu \mathrm{m}$ & $16 \mu \mathrm{m}$ & $6 \mu \mathrm{m}$ & $1 \mu m$ & $\leq 1 \mu \mathrm{m}$ \\
\hline Al & 60.5 & 6.1 & 29.3 & 4.1 & 49.7 & 12.8 & 30.6 & 7.0 \\
\hline B & 30.3 & 9.6 & 53.2 & 6.9 & 23.1 & 14.9 & 55.4 & 6.6 \\
\hline $\mathrm{Ba}$ & 40.4 & 9.6 & 43.1 & 7.0 & 30.3 & 17.6 & 48.0 & 4.1 \\
\hline $\mathrm{Ca}$ & 27.1 & 7.3 & 58.3 & 7.3 & 24.6 & 14.4 & 56.1 & 4.9 \\
\hline $\mathrm{Cd}$ & 4.6 & 2.5 & 18.0 & 74.8 & 2.1 & 3.8 & 17.2 & 76.9 \\
\hline $\mathrm{Ce}$ & 53.9 & -- & 46.1 & -- & -- & -- & 100.0 & -- \\
\hline C] & 2.5 & 1.6 & 15.3 & 80.6 & 5.2 & 11.4 & 60.2 & 23.3 \\
\hline Co & -- & -- & 58.8 & 41.2 & -- & 9.7 & 33.2 & 57.1 \\
\hline $\mathrm{Cr}$ & 4.2 & 2.6 & 22.0 & 71.2 & 19.0 & 17.9 & 30.3 & 32.8 \\
\hline CS & 2.0 & 1.9 & 18.6 & 77.6 & 1.5 & 3.8 & 22.0 & 72.2 \\
\hline $\mathrm{Cu}$ & 7.4 & 4.1 & 27.6 & 61.0 & 5.9 & 6.4 & 21.7 & 66.0 \\
\hline$F$ & 64.5 & 25.8 & 9.7 & 0 & 15.1 & 11.1 & 61.7 & 12.0 \\
\hline $\mathrm{Fe}$ & 36.1 & 10.1 & 46.8 & 7.0 & 23.6 & 17.5 & 54.2 & 4.7 \\
\hline K & -- & 1.3 & 26.5 & 72.2 & -- & 4.3 & 25.9 & 69.8 \\
\hline $\mathrm{La}$ & 41.5 & 9.2 & 44.3 & 5.0 & 31.8 & 14.7 & 50.2 & 3.3 \\
\hline Li & 8.9 & 2.7 & 29.7 & 58.7 & 6.5 & 7.0 & 31.0 & 55.5 \\
\hline $\mathrm{Mg}$ & 20.2 & 6.6 & 66.3 & 6.9 & 20.8 & 14.1 & 59.9 & 5.2 \\
\hline $\mathrm{Mn}$ & 66.2 & 7.1 & 21.2 & 5.6 & 50.7 & 14.7 & 30.1 & 4.5 \\
\hline $\mathrm{Mb}$ & -- & -- & -- & -- & -- & -- & -- & 100.0 \\
\hline $\mathrm{Na}$ & 3.3 & 1.4 & 15.5 & 79.8 & 2.6 & 3.5 & 18.5 & 75.4 \\
\hline Nd & 43.4 & 10.3 & 46.3 & -- & 25.4 & 11.8 & 40.2 & 22.7 \\
\hline $\mathrm{Ni}$ & 23.6 & 9.3 & 37.9 & 29.1 & 24.0 & 14.9 & 48.2 & 12.9 \\
\hline P & -- & -- & 100.0 & -- & 24.6 & 17.1 & 58.3 & -- \\
\hline $\mathrm{Pb}$ & -- & -- & 22.8 & 77.2 & -- & 11.0 & 18.8 & 70.2 \\
\hline Ru & -- & -- & -- & -- & -- & - & 26.2 & 13.8 \\
\hline $\mathrm{Sb}$ & -- & -- & 9.6 & 90.4 & -- & -- & 14.8 & 85.2 \\
\hline Se & 0 & 5.4 & 92.0 & 2.6 & 33.9 & 3.2 & 53.7 & 9.2 \\
\hline $\mathrm{si}$ & 29.0 & 7.6 & 50.0 & 13.4 & 15.5 & 12.7 & 49.1 & 22.7 \\
\hline S & 6.1 & 18.9 & 19.1 & 55.9 & 21.4 & 13.2 & 56.4 & 8.9 \\
\hline $\mathrm{Sr}$ & 9.1 & 2.9 & 67.7 & 20.4 & 36.6 & 9.1 & 53.5 & 0.8 \\
\hline $\mathrm{Te}$ & 2.4 & 3.0 & 52.0 & 42.7 & 1.4 & 4.1 & 27.1 & 67.4 \\
\hline $\mathrm{Ti}$ & 39.5 & 42.2 & 5.9 & 39.5 & 29.3 & 20.4 & 46.3 & 4.0 \\
\hline Zn & 16.2 & 10.4 & 34.5 & 39.0 & 19.7 & 18.2 & 31.1 & 31.0 \\
\hline $\mathrm{Zr}$ & 24.7 & 8.6 & 58.7 & 8.2 & 18.6 & 17.3 & 59.0 & 5.1 \\
\hline
\end{tabular}


TABLE A.48. PSCM-5 Gross Entrainment DFs

\begin{tabular}{|c|c|c|c|c|c|}
\hline \multirow{2}{*}{\multicolumn{2}{|c|}{ Sampl ing Period }} & \multirow{2}{*}{$\begin{array}{l}\text { Sample } \\
\text { Trupe }\end{array}$} & \multirow{2}{*}{$\begin{array}{c}\text { Feed Rate, } \\
L / h\end{array}$} & \multicolumn{2}{|c|}{ Particulate } \\
\hline & & & & Loading,(b) & DF \\
\hline $1 / 26 / 82$ & $1739-1749$ & $\mathrm{c}$ & 51 & 0.55 & 470 \\
\hline $1 / 26 / 82$ & $2201-2345$ & $S$ & 72 & 0.49 & 460 \\
\hline $1 / 27 / 82$ & $0818-1130$ & $S$ & 79 & 0.44 & 510 \\
\hline $1 / 27 / 82$ & $1758-1805$ & C & 81 & 0.61 & 440 \\
\hline $1 / 27 / 82$ & $1820-2135$ & HEPA & 81 & -- & 370 \\
\hline $1 / 28 / 82$ & $0732-1143$ & S & 86 & 0.48 & 492 \\
\hline $1 / 28 / 82$ & $1730-1738$ & c & 93 & 0.78 & 440 \\
\hline $1 / 28 / 82$ & $1920-2400$ & HEPA & 93 & -- & 670 \\
\hline $1 / 26-28$ & Average & ALL & 80 & 0.56 & 480 \\
\hline
\end{tabular}

(a) $S=$ differential sampler; $C=$ cyclone; HEPA = absolute filter.

(b) STP.

PSCM-6 - MARCH 1982

PSCM-6 was a 138-h melter experiment designed to test a new frit composition which could prove to form a more durable glass product. This experiment was nominally run under the same conditions as the previous PSCM- 5 test (see Table A.I) except that the plenum heater power was increased. However, the last 18 hours of the experiment were conducted without Iid heat boosting, allowing comparisons to also be made with the previous PSCM-4 test.

The extent of melter-generated off-gas depositions were assessed at the conclusion of this test. As in the previous PSCM test, off-gas line deposits were generally quite light. The only significant accumulations occurred around devices projecting into the off-gas lines. Qualitatively, less "hairlike" effluent (fine glass strands) was found in the off-gas lines during the present test than duriny previous tests involving the 131 frit.

Overall melter aerosol DFs were determined at two separate feeding rates by HEPA filtration of the melter exhaust stream. These data, which do not include contributions from off-gas line deposits upstream of the filter, appear in Table A.51. These results suggest that gross melter entrainment has been 


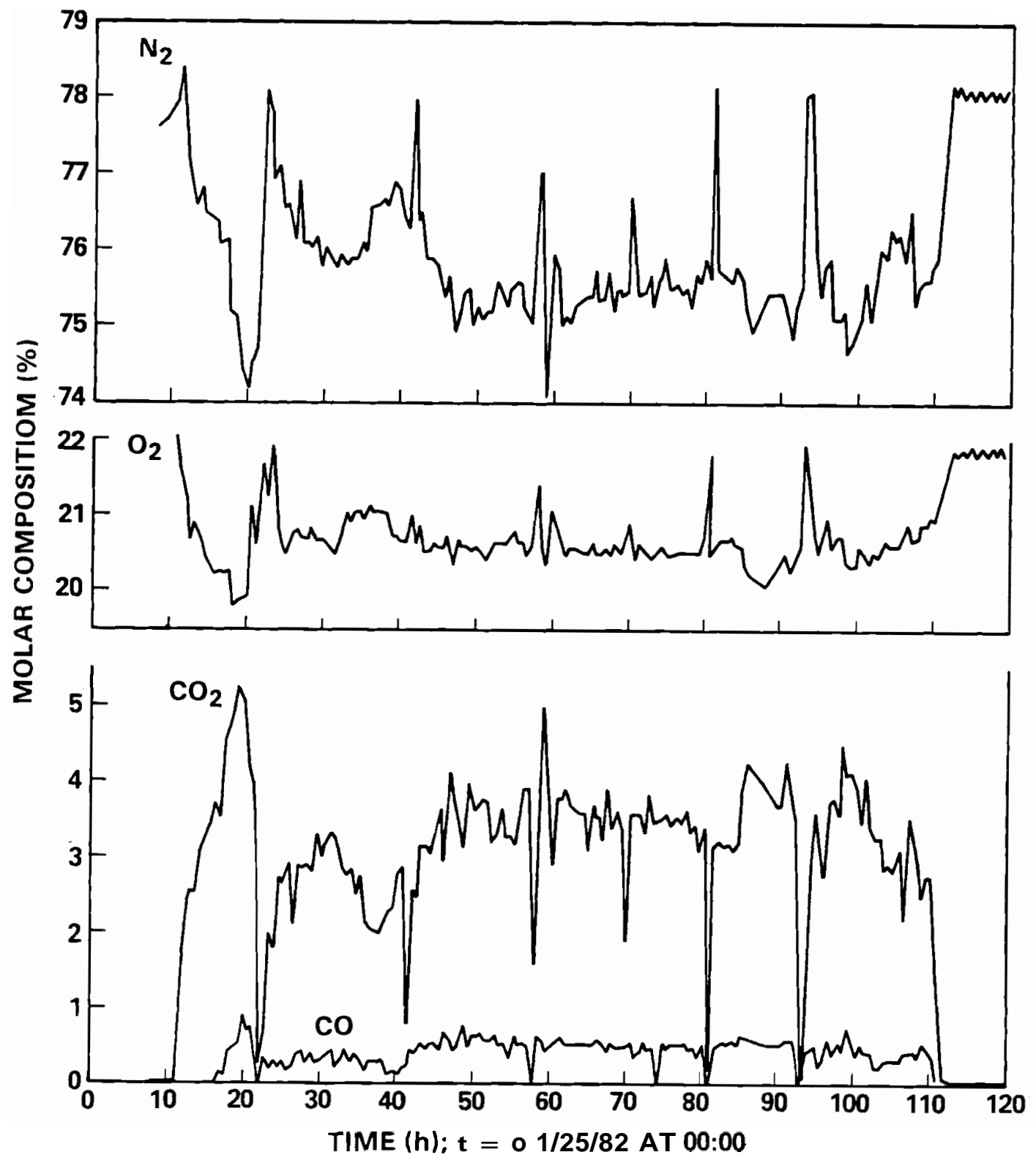

FIGURE A.72. PSCM-5 Off-Gas Composition

reduced more than for both the PSCM-4 and PSCM-5 experiments, which exhibited average DFs of $\sim 500$ and 600 , respectively.

The effect of melter operation upon individual feed component DFs was also examined during the PSCM-6 experiment. Table A.52 presents partial particulate DFs and total overall melter DFs. The absence of Ru from this table strengthens the argument that the formic acid feed component must be responsible for Ru 

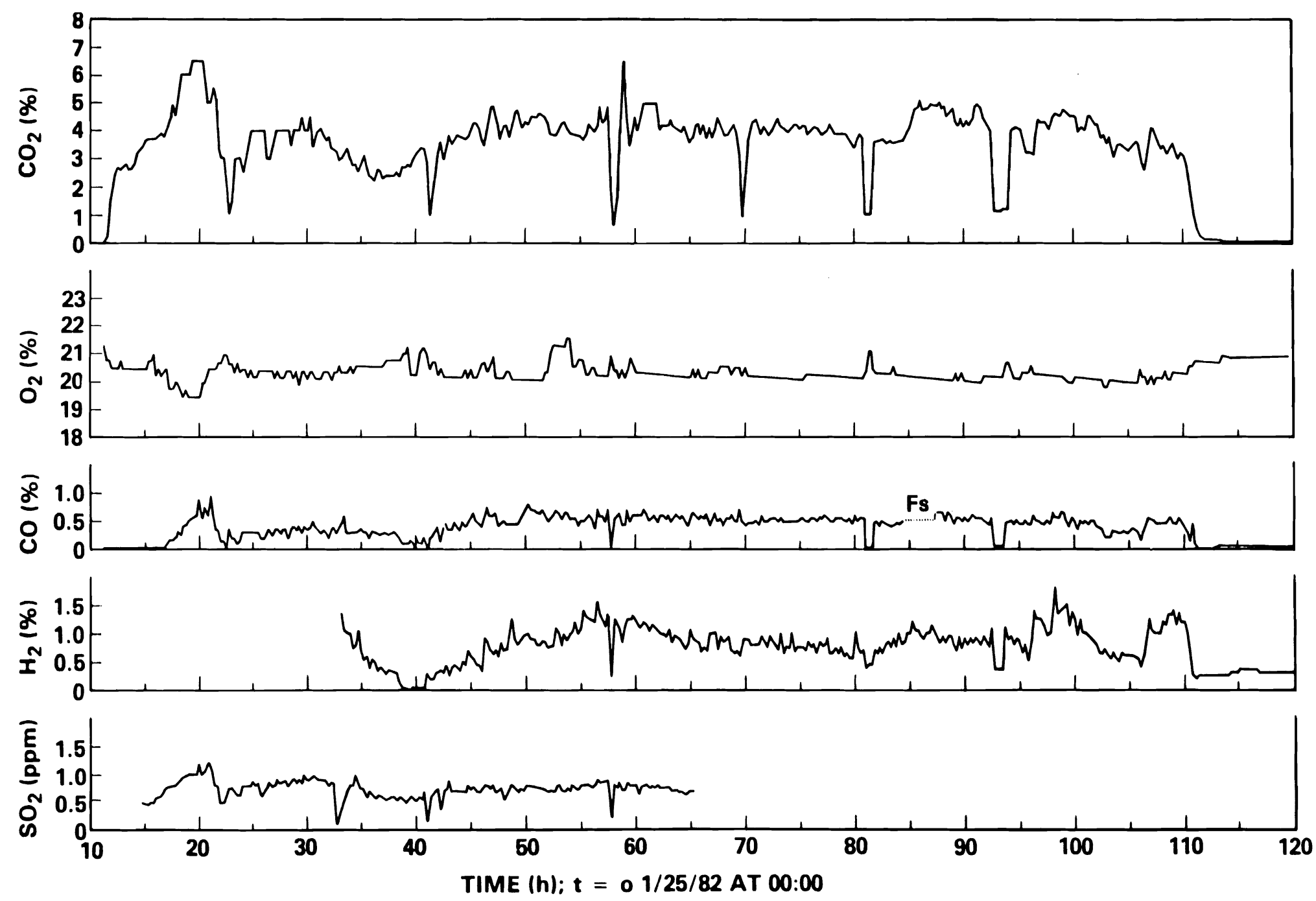

FIGURE A.73. PSCM-5 Off-Gas Composition 
TABLE A.49. PSCM-5 Noncondensible Off-Gas Composition

\begin{tabular}{|c|c|c|c|c|c|c|c|c|}
\hline \multirow[b]{3}{*}{ Date } & \multirow{3}{*}{$\begin{array}{l}\text { Data } \\
\text { Type }\end{array}$} & \\
\hline & & & & & Basis & & & \\
\hline & & $\mathrm{CO}_{2}$ & $\mathrm{O}_{2}(\mathrm{a})$ & $\mathrm{N}_{2}$ & $\mathrm{CO}$ & $\mathrm{H}$ & $\mathrm{SO}_{2} \mathrm{ppm}$ & $\mathrm{H}_{2} \mathrm{O}$ \\
\hline $1 / 25$ & Avg. & 2.4 & 21.0 & 76.4 & 0.18 & - & 0.79 & -- \\
\hline $1 / 26$ & Avg. & 2.7 & 20.6 & 76.2 & 0.32 & 0.48 & 0.75 & 81.8 \\
\hline $1 / 27$ & Avg. & 3.4 & 20.6 & 75.4 & 0.52 & 1.0 & 0.76 & 80.3 \\
\hline $1 / 28$ & Avg. & 3.2 & 20.6 & 75.7 & 0.45 & 0.81 & -- & 83.1 \\
\hline $1 / 29$ & Avg. & 2.2 & 21.1 & 76.5 & 0.27 & 0.96 & -- & -- \\
\hline $1 / 25-29$ & $\mathrm{Hi}$ & 6.5 & 21.2 & 76.9 & 0.9 & 1.8 & 1.25 & 83.1 \\
\hline $1 / 25-29$ & Lo & 2.0 & 19.8 & 74.1 & 0.1 & -- & 0.5 & 80.3 \\
\hline
\end{tabular}

(a) Includes $-1 \%$ Ar.

TABLE A.50. PSCM-5 Off-Gas-Line Deposits

\begin{tabular}{|c|c|c|c|c|}
\hline \multirow[b]{2}{*}{ Element } & \multicolumn{4}{|c|}{ Weight Percent } \\
\hline & $\begin{array}{l}\text { South } \\
\text { Viewport }\end{array}$ & $\begin{array}{c}\text { North } \\
\text { Viewport }\end{array}$ & $\begin{array}{c}\text { Off-Gas Line } \\
\text { Exiting Melter }\end{array}$ & $\begin{array}{l}\text { PSCM-5 } \\
\text { Feed } \\
\end{array}$ \\
\hline Al & 0.72 & -- & 1.8 & 2.7 \\
\hline B & 0.92 & 0.19 & 2.1 & 3.3 \\
\hline $\mathrm{Ca}$ & 0.64 & 0.02 & 1.83 & 1.2 \\
\hline $\mathrm{Cd}$ & 0.10 & 0.12 & 0.15 & 0.007 \\
\hline$C 1$ & 16.0 & 37.0 & 5.3 & 0.40 \\
\hline $\mathrm{Cr}$ & 0.82 & 0.85 & 0.17 & $<0.01$ \\
\hline Cs & 2.1 & 2.1 & 0.31 & 0.05 \\
\hline $\mathrm{F}$ & 0.26 & 7.3 & 0.66 & $<0.01$ \\
\hline $\mathrm{Fe}$ & 5.4 & 0.30 & 8.9 & 8.9 \\
\hline La & 0.10 & -- & 0.22 & 0.30 \\
\hline Li & 0.950 & 0.40 & 1.53 & 1.9 \\
\hline $\mathrm{Mg}$ & 0.21 & -- & 0.61 & 0.80 \\
\hline $\mathrm{Mn}$ & 0.56 & 0.08 & 1.08 & 1.8 \\
\hline $\mathrm{Na}$ & 17.4 & 14.0 & 11.0 & 10.0 \\
\hline Ru & 1.22 & 1.6 & 0.05 & 0.014 \\
\hline S & 3.2 & 3.7 & 1.8 & 0.05 \\
\hline Si & 6.5 & 0.12 & 15.3 & 21.0 \\
\hline $\mathrm{Sr}$ & -- & -- & 0.02 & 0.018 \\
\hline $\mathrm{Te}$ & 0.17 & 0.12 & 0.21 & 0.009 \\
\hline $\mathrm{Ti}$ & 0.16 & 0.02 & 0.37 & 0.42 \\
\hline $\mathrm{Zr}$ & 0.30 & 0.03 & 0.22 & 0.30 \\
\hline
\end{tabular}




\section{TABLE A.51. PSCM-6 Gross Melter Entrainment}

\begin{tabular}{|c|c|c|c|}
\hline \multicolumn{2}{|c|}{ Sampling Period } & \multirow{2}{*}{$\begin{array}{c}\text { Feed Rate, } \\
\mathrm{kg} / \mathrm{min}\end{array}$} & \multirow[b]{2}{*}{$\mathrm{DF}$} \\
\hline Date & Interval & & \\
\hline $3 / 24$ & $0036-1117$ & 1.5 & 810 \\
\hline $3 / 25-26$ & $2024-0040$ & 2.0 & 720 \\
\hline
\end{tabular}

melter losses (dropout). No airborne Ru has been observed during the last three melter experiments and, yet, idling emissions of particulate Ru are quite easily detected (see section on Melter Idling).

A comparison of the average PSCM-6 feed component DFs with all previous melter tests is tabulated in Table A.53. With the exception of LFCM-7, no dramatic changes in melter effluent characteristics have been observed since the introduction of the new formate feed formulation (PSCM-3).

Particle size sampling of PSCM-6-generated aerosols was also conducted using a cyclonic differential particle-size separator system. Data collected with this device during three distinct operational modes of the PSCM-6 melter are summarized in Table A.54. The size distribution of aerosols collected during PSCM-6 appears to be quite similar to that exhibited by PSCM-5. Moreover, this data suggests that lid heating has, at best, only a minor effect upon the size distribution of melter-generated aerosols.

Compositional analysis of the various particle-size fractions collected by the cyclone was conducted to establish the functional dependence of elemental loss on particle size. The resultant distribution appears in Table A.55. As has been found in all previous cases, the major carrier responsible for semivolatile melter losses is submicron particulate matter.

A summary of all measurements of melter aerosol DFs appears in Table A.56. The agreement between these results is quite satisfying. Moreover, the consistency of these results suggest that melter entrainment has not been strongly influenced by either feeding rates or lid heat boosting techniques. In addition, the average melter entrainment DF associated with PSCM-6 is greater than has been achieved by either the nonboosted PSCM- 4 or the boosted PSCM- 6 
TABLE A.52. PSCM-6 Particulate and Total Feed Components DFs

\begin{tabular}{|c|c|c|c|c|c|c|c|c|c|c|}
\hline \multirow[b]{3}{*}{ Element } & \\
\hline & \multicolumn{2}{|c|}{$3 / 23 / 82$} & \multicolumn{2}{|c|}{$3 / 24 / 82$} & \multicolumn{2}{|c|}{$3 / 25 / 82$} & \multicolumn{2}{|c|}{$3 / 26 / 82$} & \multicolumn{2}{|c|}{ Average } \\
\hline & Part & Total & Part & Total & Part & Total & Part & Total & Part & Total \\
\hline Al & $1.3 \times 10^{4}$ & $9.3 \times 10^{3}$ & $2.2 \times 10^{4}$ & $2.0 \times 10^{4}$ & $1.8 \times 10^{4}$ & $1.6 \times 10^{4}$ & $5.6 \times 10^{4}$ & $4.4 \times 10^{4}$ & $2.7 \times 10^{4}$ & $2.2 \times 10^{4}$ \\
\hline B & $2.8 \times 10^{3}$ & 105 & $3.0 \times 10^{3}$ & 100 & $3.2 \times 10^{3}$ & 100 & $1.8 \times 10^{4}$ & 110 & $6.8 \times 10^{3}$ & 100 \\
\hline $\mathrm{Ca}$ & 750 & 730 & 770 & 760 & 890 & 890 & $2.4 \times 10^{3}$ & $2.4 \times 10^{3}$ & $1.2 \times 10^{3}$ & $1.2<10^{3}$ \\
\hline Cd & 2.2 & 2.2 & 2.7 & 2.7 & 32 & 32 & 2.5 & 2.5 & 9.9 & 9.9 \\
\hline $\mathrm{Cl}$ & 26 & 2.6 & 15 & 1.9 & 11 & 2.2 & 33 & 4.7 & 21 & 2.9 \\
\hline Cs & 17 & 17 & 14 & 14 & 8.0 & 8.0 & 17 & 17 & 14 & 14 \\
\hline $\mathrm{Fe}$ & $1.4 \times 10^{3}$ & $1.4 \times 10^{3}$ & $1.8 \times 10^{3}$ & $1.7 \times 10^{3}$ & $1.8 \times 10^{3}$ & $1.8 \times 10^{3}$ & $2.4 \times 10^{3}$ & $2.3 \times 10^{3}$ & $1.9 \times 10^{3}$ & $1.8 \times 10^{3}$ \\
\hline La & $2.2 \times 10^{3}$ & $2.2 \times 10^{3}$ & $1.7 \times 10^{3}$ & $1.7 \times 10^{3}$ & $1.8 \times 10^{3}$ & $1.8 \times 10^{3}$ & $2.8 \times 10^{3}$ & $2.8 \times 10^{3}$ & $2.1 \times 10^{3}$ & $2.1 \times 10^{3}$ \\
\hline LI & $1.2 \times 10^{3}$ & $1.2 \times 10^{3}$ & $1.4 \times 10^{3}$ & $1.4 \times 10^{3}$ & -- & -- & $1.2 \times 10^{3}$ & $1.2 \times 10^{3}$ & $1.3 \times 10^{3}$ & $1.3 \times 10^{3}$ \\
\hline $\mathrm{Mg}$ & $3.5 \times 10^{3}$ & $3.5 \times 10^{3}$ & $2.3 \times 10^{3}$ & $2.3 \times 10^{3}$ & $2.3 \times 10^{3}$ & $2.3 \times 10^{3}$ & $2.3 \times 10^{4}$ & $2.3 \times 10^{4}$ & $7.8 \times 10^{3}$ & $7.8 \times 10^{3}$ \\
\hline Mn & $1.4 \times 10^{3}$ & $1.4 \times 10^{3}$ & $1.5 \times 10^{3}$ & $1.5 \times 10^{3}$ & $1.7 \times 10^{3}$ & $1.7 \times 10^{3}$ & $2.6 \times 10^{3}$ & $2.6 \times 10^{3}$ & $1.8 \times 10^{3}$ & $x \quad 10^{3}$ \\
\hline $\mathrm{Na}$ & 330 & 320 & 360 & 360 & 280 & 280 & 240 & 230 & 300 & 300 \\
\hline $\mathbf{N d}$ & $3.4 \times 10^{3}$ & $3.4 \times 10^{3}$ & $1.8 \times 10^{3}$ & $1.8 \times 10^{3}$ & $1.9 \times 10^{3}$ & $1.9 \times 10^{3}$ & $3 \times 10^{3}$ & $3 \times 10^{3}$ & $2.5 \times 10^{3}$ & $2.5 \times 10^{3}$ \\
\hline Ni & $1.2 \times 10^{3}$ & $1.2 \times 10^{3}$ & 700 & 670 & $1.1 \times 10^{3}$ & $1.0 \times 10^{3}$ & $2.1 \times 10^{3}$ & $1.6 \times 10^{3}$ & $1.3 \times 10^{3}$ & $1.1 \times 10^{3}$ \\
\hline$S$ & 2.4 & 1.9 & 5.0 & 3.8 & 22 & 12 & 13 & 4.4 & 11 & 5.5 \\
\hline Si & $6.3 \times 10^{3}$ & $\times 10^{3}$ & $3.9 \times 10^{4}$ & $1.5 \times 10^{4}$ & $3.5 \times 10^{4}$ & $1.3 \times 10^{4}$ & $4.5 \times 10^{4}$ & $\times 10^{4}$ & $3.1 \times 10^{4}$ & $1.3 \times 10^{4}$ \\
\hline $\mathrm{Sr}$ & $1.7 \times 10^{3}$ & $1.7 \times 10^{3}$ & $1.5 \times 10^{3}$ & $1.5 \times 10^{3}$ & $1.5 \times 10^{3}$ & $1.6 \times 10^{3}$ & $2.4 \times 10^{3}$ & $2.4 \times 10^{3}$ & $\times 10^{3}$ & $1.8 \times 10^{3}$ \\
\hline Te & 2.7 & 2.7 & 3.5 & 3.5 & 2.7 & 2.7 & 3.1 & 3.1 & 3.0 & 3.0 \\
\hline $\mathrm{Ti}$ & $6.0 \times 10^{3}$ & $\times 10^{3}$ & $5.0 \times 10^{3}$ & $5.0 \times 10^{3}$ & $5.5 \times 10^{3}$ & $5.5 \times 10^{3}$ & $7.2 \times 10^{3}$ & $\times 10^{3}$ & $\times 10^{3}$ & $\times 10^{3}$ \\
\hline $\mathrm{Zr}$ & $9.3 \times 10^{3}$ & $9.3 \times 10^{3}$ & $1.3 \times 10^{4}$ & $1.3 \times 10^{4}$ & $1.7 \times 10^{4}$ & $1.7 \times 10^{4}$ & $x 10^{4}$ & $4.9 \times 10^{4}$ & $\times 10^{4}$ & $2.2 \times 10^{4}$ \\
\hline
\end{tabular}


TABLE A.53. PSCM-6 Comparative DFs

\begin{tabular}{|c|c|c|c|c|c|c|c|c|c|c|c|}
\hline \multirow[b]{3}{*}{ Element } & \multirow[b]{2}{*}{ PSCM-6 } & \multicolumn{10}{|c|}{ DF Ratio } \\
\hline & & PSCM-6 & PSCM-6 & PSCM-6 & PSCM-6 & PSCM-6 & PSCM-6 & PSCM-6 & PSCM-6 & PSCM-6 & PSCM-6 \\
\hline & Avg. DF & PSCM-5 & PSCM-4 & LFCM-7 & PSCM-3 & LFCM-6 & PSCM-2 & LFCM-4 & PSCM-1 & LFCM-3 & LFCM-2 \\
\hline Al & $2.2 \times 10^{4}$ & 1.6 & 0.96 & 120 & 3.7 & 67 & 22 & 41 & 2.0 & 9.2 & 4.5 \\
\hline B & 100 & 0.71 & 0.43 & 1.3 & 0.50 & 1.1 & 0.63 & 0.77 & 0.48 & 0.83 & 0.39 \\
\hline $\mathrm{Ca}$ & $1.2 \times 10^{3}$ & 1.1 & 0.63 & 19 & 1.1 & 6.7 & 2.0 & 4.6 & 0.65 & 0.65 & 1.62 \\
\hline $\mathrm{Cd}$ & 9.9 & 1.7 & 1.1 & 1.2 & -- & 0.12 & 0.21 & 0.14 & 0.05 & 0.12 & - \\
\hline $\mathrm{Cl}$ & 2.9 & 1.9 & 0.58 & -- & 0.73 & 1.1 & 0.97 & 1.3 & 0.94 & 0.32 & 0.17 \\
\hline Cs & 14 & 1.5 & 0.88 & 1.2 & 3.7 & 1.4 & 4.7 & 0.25 & 0.27 & 2.0 & 0.35 \\
\hline $\mathrm{Fe}$ & $1.8 \times 10^{3}$ & 0.55 & 1.6 & 26 & 1.1 & 7.8 & 2.6 & 6.9 & 0.47 & 2.6 & 4.3 \\
\hline La & $2.1 \times 10^{3}$ & 2.6 & - & -- & -- & -- & -- & -- & - & -- & -- \\
\hline$L I$ & $1.3 \times 10^{3}$ & 1.8 & 0.41 & 15 & 0.50 & 8.1 & 3.8 & 4.28 & 0.68 & 2.0 & 1.4 \\
\hline $\mathrm{Mg}$ & $7.8 \times 10^{3}$ & 2.2 & -- & 65 & 0.95 & 30 & 8.5 & 22 & 0.87 & 4.3 & 16 \\
\hline$M n$ & $1.8 \times 10^{3}$ & 0.25 & 0.86 & 24 & 0.55 & 55 & 2.9 & 4.3 & 0.32 & 0.58 & 1.14 \\
\hline $\mathrm{Na}$ & 300 & 1.9 & 1.7 & 5.0 & 0.3 & 3.3 & 2.3 & 0.88 & 0.36 & 1.1 & 0.89 \\
\hline Nd & $2.5 \times 10^{3}$ & -- & - & -- & - & -- & -- & -- & -- & -- & -- \\
\hline $\mathrm{Ni}$ & $1.1 \times 10^{3}$ & 1.9 & 0.79 & -- & 0.12 & 1.2 & - & 4.2 & 0.73 & 2.6 & 2.6 \\
\hline $\mathrm{s}$ & 5.5 & 1.2 & 0.34 & - & 0.69 & 0.50 & 0.29 & 5.5 & 5.5 & 1.1 & 0.29 \\
\hline si & $1.3 \times 10^{4}$ & 2.4 & 1.4 & 110 & 4.3 & 46 & 8.1 & 31 & 0.87 & 5.0 & 14 \\
\hline $\mathrm{Sr}$ & $1.8 \times 10^{4}$ & - & 7.2 & 33 & 2.8 & 6.2 & 2.8 & 8.8 & 0.24 & 1.20 & 4.8 \\
\hline Te & 3.0 & 0.97 & 0.97 & 0.54 & 0.09 & 0.01 & 0.05 & 0.05 & 0.02 & 0.01 & 0.05 \\
\hline $\mathrm{Ti}$ & $5.9 \times 10^{3}$ & 0.82 & 0.68 & 49 & 1.4 & 35 & 4.2 & -- & -- & -- & 5.36 \\
\hline $\mathrm{Zr}$ & $2.2 \times 10^{4}$ & 1.7 & 4.4 & - & - & -- & -- & -- & -- & -- & -- \\
\hline
\end{tabular}

TABLE A.54. PSCM-6 Differential Particle Size Data

\begin{tabular}{|c|c|c|c|c|c|c|c|c|c|}
\hline \multirow{2}{*}{\multicolumn{2}{|c|}{ Sampling Period }} & \multirow[b]{2}{*}{ WT } & \multirow{2}{*}{\multicolumn{3}{|c|}{ Versus Cut Point }} & \multicolumn{2}{|c|}{ Particulate } & \multirow[b]{2}{*}{$\begin{array}{c}\text { Feed Rate, } \\
\mathrm{kg} / \mathrm{min}\end{array}$} & \multirow[b]{2}{*}{$\begin{array}{l}\text { Lid Heat } \\
\text { (?) }\end{array}$} \\
\hline & & & & & & $\begin{array}{l}\text { Loading, } \\
\mathrm{mg} / \mathrm{L}\end{array}$ & DF & & \\
\hline $3 / 24$ & $1125-1137$ & 67.1 & 0.9 & 14.9 & 17.1 & 0.37 & 840 & 15 & Yes \\
\hline $3 / 25$ & $1220-1229$ & 38.6 & - & 14.6 & 46.8 & 0.41 & 700 & 2.0 & Yes \\
\hline $3 / 26$ & $1430-1453$ & 32.5 & 0.7 & 8.6 & 58.2 & 0.54 & 660 & 1.3 & No \\
\hline
\end{tabular}

experiments. Although the differences in these DFs are not startling, the result may be a reflection of the new glass formulation which has distinguished the PSCM- 6 test.

The noncondensible composition of the melter-generated exhaust was continuously recorded during PSCM- 6 using real-time gas monitors. A composite plot of all the gas data generated appears in Figure A.74. The most interesting feature of this figure is the absence of significant combustible gas concentrations throughout most of the run. Only after the lid heaters had been turned off $\mathrm{did}_{2}$ and $\mathrm{CO}$ concentrations increase to significant levels. 
TABLE A.55. Feed Component Distribution Across Cyclonic Aerosol Size Fractions

Elemental Distribution, $\%$

\begin{tabular}{|c|c|c|c|c|c|c|c|c|c|c|c|c|}
\hline \multirow[b]{3}{*}{ Element } & \multicolumn{4}{|c|}{$3 / 24 / 82$} & \multicolumn{4}{|c|}{$3 / 25 / 82$} & \multicolumn{4}{|c|}{$3 / 26 / 82$} \\
\hline & \multicolumn{4}{|c|}{ Size Fraction } & \multicolumn{4}{|c|}{ Size Fraction } & \multicolumn{4}{|c|}{ Size fraction } \\
\hline & $16 \mu \mathrm{nI}$ & $6 \mu \mathrm{m}$ & $1 \mu \mathrm{m}$ & $<1 \mu \mathrm{m}$ & $16 \mu \mathrm{m}$ & $6 \mu \mathrm{m}$ & $I \mu \mathrm{m}$ & $s 1 \mu \mathrm{m}$ & $16 \mu \mathrm{m}$ & $6 \mu \mathrm{m}$ & $I \mu \Pi$ & $\leq 1 \mu m$ \\
\hline $\mathrm{Al}$ & 92.8 & -- & 2.8 & 4.4 & 75.5 & $\ldots$ & 13.4 & 11.1 & 89.8 & -- & 10.2 & -- \\
\hline B & 69.7 & -- & 19.7 & 10.6 & 39.3 & - & 35.0 & 25.7 & 68.0 & -- & 27.3 & 4.7 \\
\hline $\mathrm{Ba}$ & 79.6 & -- & 9.8 & 10.6 & 25.6 & -- & 34.0 & 40.4 & 77.8 & -- & 26.2 & -- \\
\hline $\mathrm{Ca}$ & 61.4 & -- & 23.5 & 15.0 & 41.1 & -- & 38.9 & 20.0 & 58.4 & -- & 36.6 & 5.0 \\
\hline $\mathrm{Cd}$ & 14.3 & -- & 16.5 & 69.1 & 6.3 & -- & 9.9 & 83.8 & 12.2 & $-\infty$ & 10.9 & 76.9 \\
\hline $\mathrm{Ce}$ & 100.0 & -- & -- & -- & -- & -- & -- & -- & 100.0 & -- & -- & -- \\
\hline $\mathrm{Cl}$ & 78.4 & -- & 15.1 & 6.5 & 19.8 & -- & 44.4 & 35.8 & 1.7 & -- & 6.2 & 92.2 \\
\hline Co & 98.5 & -- & 1.5 & -- & 29.1 & -- & 11.0 & 59.9 & 30.1 & -- & 16.0 & 53.9 \\
\hline $\mathrm{Cr}$ & 95.5 & -- & 1.9 & 2.5 & 91.3 & -- & 4.6 & 4.1 & 84.4 & -- & 9.3 & 6.3 \\
\hline Cs & 24.0 & -- & 21.0 & 55.0 & 2.55 & -- & 13.2 & 84.3 & 23.7 & -- & 9.2 & 67.1 \\
\hline $\mathrm{Cu}$ & 65.0 & -- & 13.2 & 21.8 & 23.4 & -- & 27.1 & 49.5 & 27.5 & -- & 20.7 & 51.7 \\
\hline Dy & 81.8 & -- & 18.2 & -- & 46.8 & - & 53.2 & -- & 55.6 & $\cdots$ & 44.4 & -- \\
\hline$F$ & 93.5 & -- & 4.2 & 2.3 & 18.9 & - & 64.9 & 16.2 & 1.7 & -- & 10.0 & 88.3 \\
\hline $\mathrm{Fe}$ & 86.4 & -- & 10.1 & 3.5 & 73.9 & -- & 23.6 & 2.4 & 60.2 & -- & 35.9 & 3.9 \\
\hline$k$ & 24.5 & -- & 16.3 & 59.2 & 2.3 & - & 13.0 & 84.7 & 11.3 & -- & 7.5 & 81.1 \\
\hline La & 81.8 & -- & 18.2 & -- & 46.9 & -- & 44.5 & 8.5 & 56.5 & -- & 40.1 & 3.4 \\
\hline Li & 37.5 & -- & 8.9 & 43.6 & 17.1 & -- & 19.9 & 63.0 , & 18.4 & -- & 9.1 & 72.5 \\
\hline Mg & 64.3 & -- & 12.4 & 23.3 & 35.8 & -- & 28.4 & 35.9 & 85.5 & -- & 14.5 & -- \\
\hline Mn & 66.3 & -- & 31.3 & 2.5 & 61.3 & -- & 34.8 & 4.0 & 57.9 & -- & 37.7 & 4.4 \\
\hline Mo & 33.4 & - & 18.5 & 48.1 & 33.9 & -- & 15.6 & 50.5 & 49.1 & -- & 15.7 & 35.2 \\
\hline $\mathrm{Na}$ & 43.0 & -- & 13.5 & 43.6 & 8.5 & -- & 14.2 & 77.3 & 16.4 & -- & 6.3 & 77.4 \\
\hline $\mathrm{Nd}$ & 60.0 & -- & 40.0 & -- & 39.7 & -- & 60.3 & -- & 51.8 & -- & 48.2 & -- \\
\hline$N 1$ & 94.3 & - & 5.2 & 0.5 & 63.0 & -- & 30.8 & 6.2 & 59.6 & $\ldots$ & 32.0 & 8.4 \\
\hline$P$ & -- & -- & - & 100.0 & -- & $-\infty$ & -- & 100.0 & 100.0 & -- & -- & -- \\
\hline PD & 15.6 & -- & 15.2 & 64.3 & 5.3 & -- & 15.1 & 79.6 & 35.4 & -- & 1.2 & 63.4 \\
\hline Si & 64.8 & -- & 12.3 & 22.8 & 38.2 & - & 24.9 & 36.8 & 51.9 & -- & 31.4 & 16.7 \\
\hline$S$ & 67.5 & -- & 25.7 & 6.8 & 11.8 & -- & 67.0 & 21.2 & 77.3 & -- & 2.9 & 19.8 \\
\hline $\mathrm{Sr}$ & 60.8 & -- & 27.0 & 12.2 & 40.7 & -- & 27.3 & 32.0 & 56.5 & -- & 30.0 & 13.5 \\
\hline Te & 14.7 & -- & 17.7 & 67.6 & 51.3 & -- & 48.7 & -- & 11.7 & -- & 23.7 & 64.6 \\
\hline $\mathrm{Ti}$ & 51.7 & -- & 48.3 & -- & 5.20 & -- & 12.2 & 82.6 & 94.6 & -- & 5.4 & -- \\
\hline $2 n$ & 52.0 & -- & 11.5 & 36.5 & 25.8 & -- & 22.9 & 51.2 & 40.0 & -- & 22.4 & 37.7 \\
\hline$Z r$ & 79.0 & -- & 21.0 & -- & 55.3 & -- & 39.8 & 4.9 & 81.8 & -- & 14.8 & 3.3 \\
\hline
\end{tabular}

Apparently an $850^{\circ} \mathrm{C}$ plenum temperature is more than sufficient to burn all combustibles before they were able to pass into the off-gas line. The discontinuities present in these data plots are produced by instrument calibrations. A summary of this gas compositional data is tabulated in Table A.57. 
TABLE A.56. PSCM-6 Aerosol DFs

\begin{tabular}{|c|c|c|c|c|c|}
\hline \multicolumn{2}{|c|}{ Sampl ing Period } & \multirow{2}{*}{$\begin{array}{l}\text { Sample } \\
\text { Type }\end{array}$} & \multirow[b]{2}{*}{$\begin{array}{c}\text { Feed Rate, } \\
\mathrm{L} / \mathrm{h}\end{array}$} & \multirow[b]{2}{*}{$\begin{array}{c}\text { Loading, } \\
\mathrm{mg} / \mathrm{L}\end{array}$} & \multirow[b]{2}{*}{ DF } \\
\hline$\frac{\mathrm{Sam}}{\mathrm{Mo} / \mathrm{d}}$ & $\frac{g \text { Period }}{\text { Interval }}$ & & & & \\
\hline $3 / 23$ & $1735-1920$ & S & 68 & 0.29 & 820 \\
\hline $3 / 24$ & $0036-1117$ & HEPA & -- & -- & 810 \\
\hline $3 / 24$ & $1125-1137$ & C & 67 & 0.37 & 840 \\
\hline $3 / 24$ & $1615-1841$ & S & 74 & 0.25 & 910 \\
\hline $3 / 25$ & $1220-1229$ & C & 90 & 0.41 & 700 \\
\hline $3 / 25$ & $1620-1835$ & S & 91 & 0.28 & 840 \\
\hline $3 / 25$ & $2024-0040$ & HEPA & -- & -- & 720 \\
\hline $3 / 26$ & $0915-1141$ & S & 58 & 0.32 & 870 \\
\hline $3 / 26$ & $1430-1453$ & c & 58 & 0.54 & 660 \\
\hline $3 / 23-26$ & Average & ALL & & & 800 \\
\hline
\end{tabular}

(a) $\mathrm{S}=$ sample train; $\mathrm{C}=$ cyclone; $\mathrm{HEPA}=$ absolute filtration.

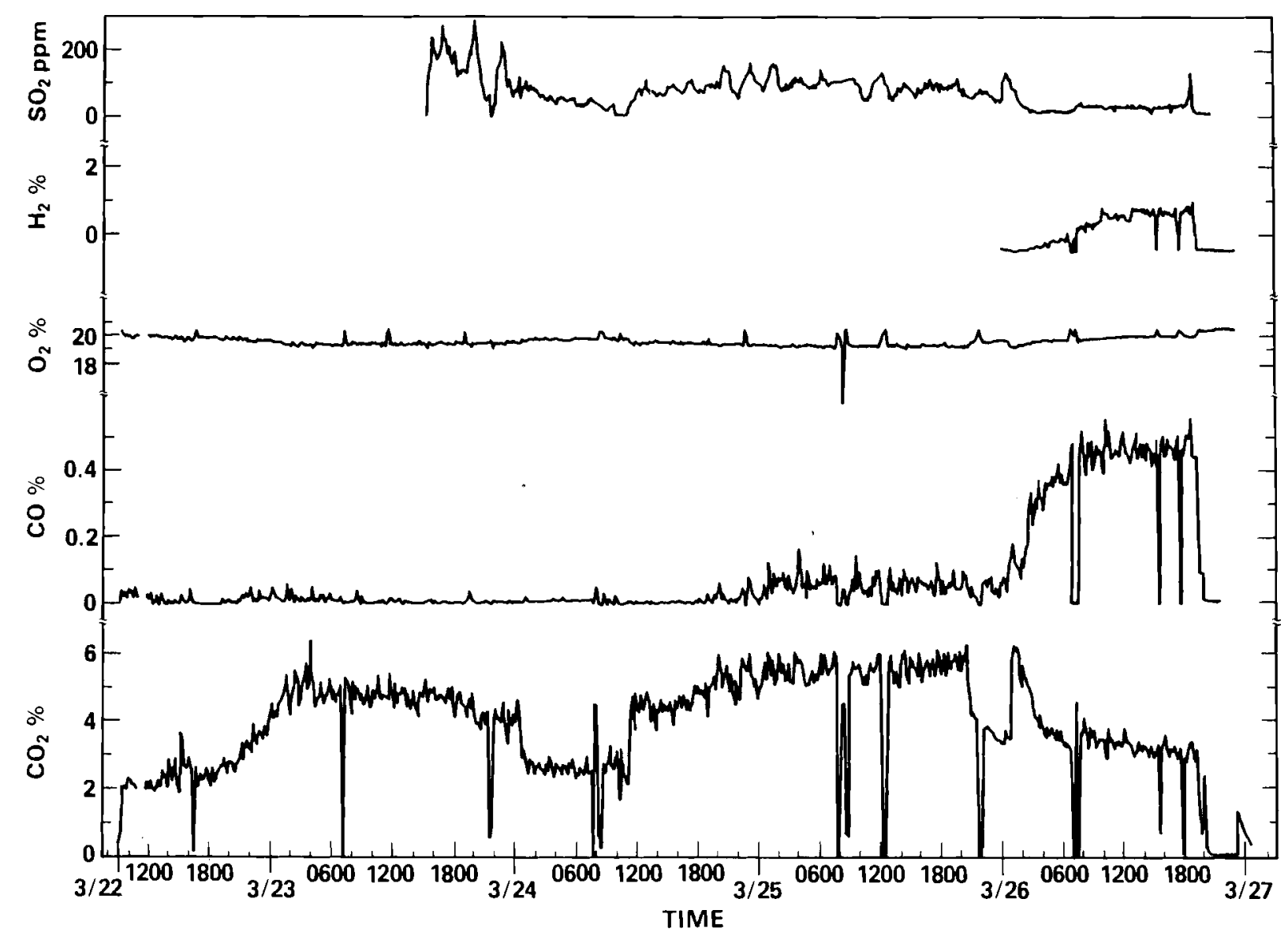

FIGURE A.74. PSCM-6 Off-Gas Composition 


\section{TABLE A.57. PSCM-6 Off-Gas Composition}

\begin{tabular}{|c|c|c|c|c|c|c|c|c|}
\hline \multirow[b]{3}{*}{ Date } & \multirow{3}{*}{$\begin{array}{l}\text { Data } \\
\text { Type }\end{array}$} & \multicolumn{7}{|c|}{ Molar Composition, $\%$} \\
\hline & & & & & ry $\mathrm{Bas}$ & & & \\
\hline & & $\overline{\mathrm{CO}_{2}}$ & $\mathrm{O}_{2}(\mathrm{a})$ & $\mathrm{N}_{2}$ & $\mathrm{CO}$ & & $\mathrm{SO}_{2}(\mathrm{a})$ & $\mathrm{H}_{2} \mathrm{O}$ \\
\hline $3 / 22$ & Avg. & 2.6 & 19.8 & & 0.002 & -- & -- & -- \\
\hline $3 / 23$ & Avg. & 5.2 & 19.0 & -- & 0.011 & -- & 154 & 66 \\
\hline $3 / 24$ & Avg. & 3.9 & 18.8 & -- & 0.014 & -- & 69 & 67 \\
\hline $3 / 25$ & Avg. & 5.3 & 18.7 & -. & 0.060 & -- & 85 & 69 \\
\hline $3 / 26$ & Avg. & 3.7 & 19.3 & -- & 0.382 & 1.1 & 27 & 55 \\
\hline
\end{tabular}

(a) ppm.

The nature of combustible yas generation within an operating melter was also investigated during PSCM-6. Figure A.75 portrays the time-dependent compositional behavior of the melter exhaust stream upon feed interruption or termination. With the exception of $\mathrm{SO}_{2}$, none of the melter-generated gases increased in concentration when feeding was terminated. This fact implies that volatile decomposition and reaction products generated from the melter feed are formed soon after introduction of the feed into the melter environment.

Consequently, chemically reactive organic feed components within the melter cold cap apparently do not accumulate significantly under steady-state feeding conditions.

On the other hand, the increase in terminal $\mathrm{SO}_{2}$ exhaust concentration (illustrated in Figure A.75) suggests that sulfur, as $\mathrm{Na}_{2} \mathrm{SO}_{4}$, may be accumulating within the melter as a molten salt. Post-run inspection of the idling melter glass surface later proved this. This observation stimulated speculation that accumulations of $\mathrm{Na}_{2} \mathrm{SO}_{4}$ could be responsible for changes in the melting capacity of liquid-fed melters during the initial $-24 \mathrm{~h}$ of liquid feeding (the startup phase). Melter emissions of $\mathrm{SO}_{2}$ during the PSCM-8 test further support this notion, as will be shown in the next section.

Off-gas deposits were taken from the off-gas lines and viewports after PSCM-6. The results are shown in Table A.58. These results are similar to each other and to past runs, which have shown off-gas-line deposits enriched in $\mathrm{Cl}, \mathrm{Cs}, \mathrm{Na}, \mathrm{S}, \mathrm{Te}, \mathrm{Cd}$, and Ru. The overflow sampling port shows the most 


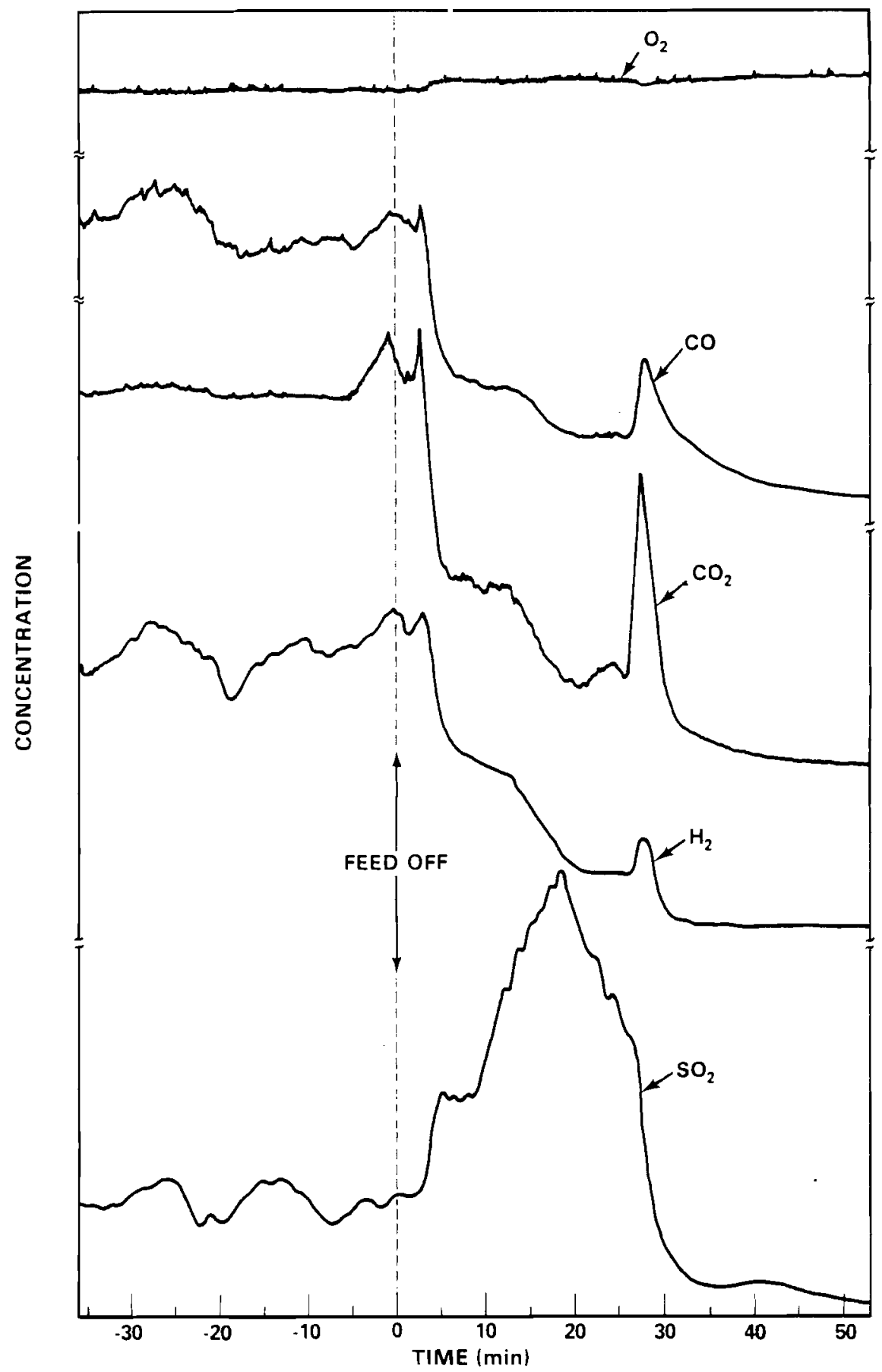

FIGURE A.75. Melter Off-Gas Compositional Behavior Associated with Feed Termination. (The $\mathbf{t}=30 \mathrm{~min}$ compositional spike is due to the injection of a small quantity of liquid feed.) 
TABLE A.58. Off-Gas-Line Deposits (wt\%) - PSCM-5 \& -6

\begin{tabular}{|c|c|c|c|c|c|c|}
\hline Element & $\begin{array}{l}\text { South } \\
\text { Viewport }\end{array}$ & $\begin{array}{c}\text { North } \\
\text { Viewport } \\
\end{array}$ & $\begin{array}{c}\text { Off-Gas Line } \\
\text { Exiting Melter } \\
\end{array}$ & $\begin{array}{l}\text { Overflow } \\
\text { Sample } \\
\text { Port } \\
\end{array}$ & $\begin{array}{l}\text { Off-Gas } \\
\text { Cooling } \\
\text { Nozzle } \\
\end{array}$ & $\begin{array}{l}\text { PSCM-6 } \\
\text { Feed } \\
\end{array}$ \\
\hline Al & 0.37 & 0.33 & 0.21 & 1.0 & 1.39 & 2.7 \\
\hline B & 0.34 & 0.35 & 1.41 & 0.48 & 0.82 & 2.2 \\
\hline $\mathrm{Ca}$ & 0.26 & 0.34 & 0.43 & 0.16 & 3.84 & 1.1 \\
\hline $\mathrm{Cd}$ & 0.20 & 0.15 & 0.17 & 0.02 & 0.38 & 0.004 \\
\hline $\mathrm{C} 1$ & 18.0 & 17.0 & 18.0 & 36.0 & 4.3 & 0.42 \\
\hline $\mathrm{Cr}$ & 3.2 & 0.04 & 2.96 & 0.09 & 0.21 & $<0.01$ \\
\hline Cs & 1.4 & 1.1 & 0.52 & 3.3 & 0.26 & 0.05 \\
\hline $\mathrm{F}$ & 0.25 & 0.28 & 1.2 & 0.39 & 0.8 & $<0.01$ \\
\hline $\mathrm{Fe}$ & 2.3 & 7.6 & 21.7 & 0.41 & 10.9 & 7.1 \\
\hline $\mathrm{La}$ & 0.02 & 0.02 & 0.01 & -- & 0.15 & 0.05 \\
\hline Li & 0.84 & 0.51 & 0.71 & 0.97 & 1.33 & 2.33 \\
\hline M9 & -- & -- & -- & -- & 0.41 & 0.46 \\
\hline $\mathrm{Mn}$ & 0.33 & 0.41 & 1.63 & -- & 2.68 & 2.1 \\
\hline $\mathrm{Na}$ & 20.4 & 15.0 & 8.4 & 2.3 & 5.54 & 7.6 \\
\hline $\mathrm{Ru}$ & 0.60 & 1.8 & -- & 0.53 & 0.04 & 0.014 \\
\hline$S$ & 8.0 & 4.3 & 2.8 & 2.7 & 3.2 & 0.05 \\
\hline Si & 2.4 & 2.3 & 2.4 & 0.41 & 16.0 & 25.0 \\
\hline $\mathrm{Sr}$ & 0.005 & -- & -- & -- & 0.05 & 0.018 \\
\hline $\mathrm{Te}$ & 0.26 & 0.35 & 0.08 & 0.09 & 0.76 & 0.007 \\
\hline $\mathrm{Ti}$ & 0.05 & 0.08 & 0.01 & -- & 0.05 & 0.07 \\
\hline $\mathrm{Zr}$ & 0.21 & 0.08 & 0.09 & 0.08 & 0.34 & 0.57 \\
\hline
\end{tabular}

enrichment in the semivolatiles because all the deposits come from volatilization, while the other deposits contain volatilized and entrained material.

PSCM-7 - MAY 1982

PSCM-7 was a 115-h nonboosted melter experiment designed to assess the effect of increased slurry solids loading (decreased water loadiny) upon maximum achievable melter feeding rates. In addition, an air sparge was utilized at the conclusion of this experiment to test the effects of forced melter glass convection upon feed melting rates. The new glass former, Frit-165, which was utilized for the first time during PSCM-6, was also employed during PSCM-7. 
There was little melter off-gas-line deposition apparent at the conclusion of PSCM-7. The minor accumulations that did occur all formed around off-gas line penetrations as in the past. The overall deposition rate associated with PSCM-7, however, appeared to be less than that of the previous boosted PSCM-6 experiment.

Gross melter DF was measured during steady state feeding by HEPA filtration of the entire melter exhaust stream. The resultant DF, which appears in Table A.59, is significantly higher than the -800 value recorded during PSCM-6, and further confirms the qualitative statement made above with regard to PSCM-7 off-gas line deposition rates.

Differential sampling of the PSCM-7 melter off-gas stream was also conducted in order to establish individual melter feed component DFs. Table A.60 presents these data in terms of partial particulate and total overall melter DFs. As has been the case for all formate feed tests, no airborne Ru was detectable in the PSCM-7 off-gas stream.

A comparison of average melter feed component DFs for PSCM-7 with a11 previous liquid-fed melter tests is given in Table A.61. Overall, the emissions during PSCM-7 are some of the lowest ever recorded. However, Cs DFs are quite comparable to all previous PSCM formate feed tests.

Particulate size analysis of the melter-generated aerosols was also conducted during PSCM-7. The results of these studies are summarized in Table A.62. The size distributions of PSCM-7 aerosols are much like those from previous PSCM tests (bimodal in nature) except that the overall, distribution is much more heavily weighted by the small diameter component during PSCM-7.

Compositional analysis of the various particle-size fractions collected by the cyclone was conducted to establish the dependence of elemental loss on

\section{TABLE A.59. Gross Melter DF}

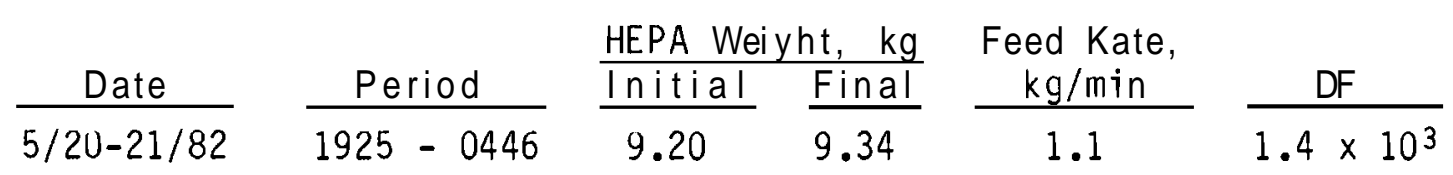


TABLE A.60. PSCM-7 Particulate and Total Feed Components DFs

\begin{tabular}{|c|c|c|c|c|c|c|c|c|}
\hline \multirow[b]{2}{*}{ Element } & \multicolumn{2}{|c|}{$5 / 18$ DFs } & \multicolumn{2}{|c|}{$5 / 20$ DFs } & \multicolumn{2}{|c|}{$5 / 21 \mathrm{DFs}^{(\mathrm{a})}$} & \multicolumn{2}{|c|}{ Average DFs } \\
\hline & Part & Total & Part & Total & Part & Total & Part & Total \\
\hline $\mathrm{Al}$ & $3.3 \times 10^{4}$ & $2.6 \times 10^{4}$ & $4.7 \times 10^{4}$ & $4.3 \times 10^{4}$ & $8.2 \times 10^{3}$ & $8.2 \times 10^{3}$ & 29,000 & 2,600 \\
\hline B & $1.2 \times 10^{4}$ & 204 & $1.0 \times 10^{4}$ & 214 & $1.9 \times 10^{3}$ & 202 & 8,000 & 210 \\
\hline $\mathrm{Ca}$ & $3.5 \times 10^{3}$ & $3.2 \times 10^{3}$ & $3.8 \times 10^{3}$ & $3.6 \times 10^{3}$ & 921 & 910 & 2,700 & 2,600 \\
\hline Cd & 8.0 & 8.0 & 4.0 & 4.0 & 7.4 & 7.4 & 6.5 & 6.5 \\
\hline $\mathrm{Cl}$ & 15.7 & 11 & 12 & 4.8 & 9.5 & 3.3 & 12 & 6.4 \\
\hline Cs & 16.2 & 16.2 & 13 & 13 & 10.2 & 10.2 & 13 & 13 \\
\hline $\mathrm{Fe}$ & $3.9 \times 10^{3}$ & $3.9 \times 10^{3}$ & $5.2 \times 10^{3}$ & $3.0 \times 10^{3}$ & $1.4 \times 10^{3}$ & $1.4 \times 10^{3}$ & 3,500 & 2800 \\
\hline La & $3.2 \times 10^{3}$ & $3.2 \times 10^{3}$ & $6.5 \times 10^{3}$ & $6.5 \times 10^{3}$ & $1.2 \times 10^{3}$ & $1.2 \times 10^{3}$ & 3,600 & 3,600 \\
\hline Li & $1.4 \times 10^{3}$ & $1.4 \times 10^{3}$ & $1.3 \times 10^{3}$ & $1.3 \times 10^{3}$ & 678 & 678 & 1,100 & 1,100 \\
\hline Mg & $1.5 \times 10^{4}$ & $1.5 \times 10^{4}$ & $1.4 \times 10^{4}$ & $1.4 \times 10^{4}$ & $3.2 \times 10^{3}$ & $3.2 \times 10^{3}$ & 11,000 & 11,000 \\
\hline$M n$ & $5.5 \times 10^{3}$ & $5.4 \times 10^{3}$ & $4.8 \times 10^{3}$ & $4.4 \times 10^{3}$ & $1.2 \times 10^{3}$ & $1.2 \times 10^{3}$ & 3,800 & 3,700 \\
\hline $\mathrm{Na}$ & 345 & 345 & 323 & 322 & 191 & 191 & 290 & 290 \\
\hline Nd & $6.4 \times 10^{3}$ & $6.4 \times 10^{3}$ & $5.7 \times 10^{3}$ & $5.7 \times 10^{3}$ & 311 & 311 & 4,100 & 4,100 \\
\hline $\mathrm{Ni}$ & $6.2 \times 10^{3}$ & $5.4 \times 10^{3}$ & $6.0 \times 10^{3}$ & $1.6 \times 10^{3}$ & $2.7 \times 10^{3}$ & $2.4 \times 10^{3}$ & 5,000 & 3,100 \\
\hline $\mathrm{s}$ & 40 & 3.0 & 359 & 1 & 64.9 & 4.6 & 150 & 2.9 \\
\hline Sb & 730 & 730 & 793 & 793 & 620 & 620 & 710 & 710 \\
\hline $\mathrm{Se}$ & 2.8 & 2.8 & 90 & 90 & 28.8 & 28.8 & 40 & 40 \\
\hline si & $1.5 \times 10^{4}$ & $1.1 \times 10^{4}$ & $1.9 \times 10^{4}$ & $9.8 \times 10^{3}$ & $5.4 \times 10^{3}$ & $5.3 \times 10^{3}$ & 13,000 & 8,700 \\
\hline $\mathrm{Sr}$ & $5.3 \times 10^{3}$ & $5.3 \times 10^{3}$ & $6.2 \times 10^{3}$ & $6.2 \times 10^{3}$ & 960 & 960 & 4,200 & 4,200 \\
\hline $\mathrm{Te}$ & 8.4 & 8.4 & 23 & 23 & 43.3 & 43.3 & 24 & 24 \\
\hline $\mathrm{Ti}$ & $7.6 \times 10^{3}$ & $7.6 \times 10^{3}$ & $3.3 \times 10^{4}$ & $3.3 \times 10^{4}$ & $5.1 \times 10^{3}$ & $5.1 \times 10^{3}$ & 15,000 & 15,000 \\
\hline $\mathrm{Zr}$ & $2.0 \times 10^{4}$ & $2.0 \times 10^{4}$ & $2.8 \times 10^{4}$ & $3.3 \times 10^{3}$ & $4.9 \times 10^{3}$ & $4.9 \times 10^{3}$ & 18,000 & 9,400 \\
\hline
\end{tabular}

(a) Air sparge In operation.

particle size. The resultant distributional data appear in Table A.63. As in all previous cases, the major carrier responsible for semivolatile melter losses is submicron particulate matter.

The performance of the newly installed venturi ejector was also evaluated during the present test. In this study, off-gas aerosol DFs were established for individual effluent species. This data appears in Table A.64. The values listed are consistent with anticipated performance.

A summary of melter-scrubber performance as determined by off-gas particulate loading appears in Table A.65. The data are quite consistent. The low melter and high scrubber DFs recorded on $5 / 21$ resulted from melter sparging. Apparently, sparginy increased gross feed component carryover into the 
TABLE A.61. PSCM-7 Comparative DFs

\begin{tabular}{|c|c|c|c|c|c|c|c|c|c|c|c|c|}
\hline \multirow[b]{3}{*}{ Element } & \multirow[b]{2}{*}{ PSCM-7 } & \multicolumn{11}{|c|}{ DF Ratio } \\
\hline & & PSCM-7 & PSCM-7 & PSCM-7 & PSCM-7 & PSCM-7 & PSCM-7 & PSCM-7 & PSCM-7 & PSCM-7 & PSCM-7 & PSCM-7 \\
\hline & Average DF & $\overline{\mathrm{PSCM}-6}$ & PSCM-5 & PSCM-4 & LFCM-7 & $\overline{\mathrm{PSCM}-3}$ & $\overline{\text { LFCM-6 }}$ & $\overline{P S C M-2}$ & LFCM-4 & $\overline{P S C M-1}$ & $\overline{\mathrm{LFCM}-3}$ & LFCM-2 \\
\hline Al & 26,000 & 1.2 & 1.8 & 1.1 & 135.0 & 4.3 & 78.0 & 26.0 & 49.0 & 2.3 & 11.0 & 5.2 \\
\hline B & 210 & 2.1 & 1.5 & 0.9 & 2.8 & 1.0 & 2.3 & 1.3 & 1.6 & 1.0 & 1.7 & 0.80 \\
\hline $\mathrm{Ca}$ & 2,600 & 2.1 & 2.3 & 1.4 & 42.0 & 2.3 & 14.0 & 4.2 & 1.0 & 1.4 & 1.4 & 3.5 \\
\hline Cd & 6.5 & 0.65 & 1.1 & 0.70 & 0.81 & - & 0.08 & 0.14 & 0.09 & 0.03 & 0.08 & 0.02 \\
\hline $\mathrm{Cl}$ & 6.4 & 2.2 & 4.2 & 1.3 & - & 1.6 & 2.4 & 2.1 & 2.9 & 2.0 & 0.71 & 0.37 \\
\hline Cs & 13 & 0.94 & 1.4 & 0.82 & 1.1 & 3.5 & 1.3 & 4.4 & 0.23 & 0.26 & 1.9 & 0.33 \\
\hline $\mathrm{Fe}$ & 2,800 & 1.6 & 2.6 & 1.4 & 42.0 & 1.8 & 12.0 & 4.1 & 11.0 & 0.79 & 4.2 & 6.7 \\
\hline La & 3,600 & 1.7 & 0.36 & -- & -- & -- & -- & -- & -- & -- & -- & -- \\
\hline LI & 1,100 & 0.87 & 1.5 & 0.35 & 12.0 & 0.43 & 7.0 & 3.3 & 3.6 & 0.59 & 1.7 & 1.2 \\
\hline $\mathrm{Mg}$ & 11,000 & 1.4 & 3.1 & 0.01 & 89.0 & 1.3 & 41.0 & 11.0 & 30.0 & 1.2 & 6.0 & 22 \\
\hline$M n$ & 3,700 & 2.0 & 0.52 & 1.8 & 48.0 & 1.1 & 11.0 & 5.8 & 8.7 & 0.64 & 1.2 & 2.3 \\
\hline $\mathrm{Na}$ & 290 & 0.95 & 1.8 & 1.6 & 4.8 & 0.32 & 3.2 & 2.2 & 0.84 & 0.34 & 1.0 & 0.85 \\
\hline Nd & 4,100 & 1.65 & -- & -- & -- & -- & - & -- & - & -- & -- & -- \\
\hline $\mathrm{Ni}$ & 3,100 & 2.8 & 5.4 & 2.2 & -- & 0.33 & 3.4 & -- & 12.0 & 2.1 & 7.3 & 7.3 \\
\hline $\mathrm{S}$ & 2.9 & 0.52 & 0.64 & 0.18 & - & 0.36 & 0.26 & 0.15 & 2.9 & 2.9 & 0.57 & 0.15 \\
\hline $\mathrm{Sb}$ & 710 & -- & 1.6 & -- & 10.0 & -- & -- & 7.1 & 0.40 & -- & -- & 1.5 \\
\hline $\mathrm{Se}$ & 40 & -- & 0.31 & -- & 40.0 & -- & -- & -- & -- & -- & - & 0.19 \\
\hline Si & 8,700 & 0.67 & 1.6 & 0.95 & 72.0 & 2.9 & 31.0 & 5.4 & 20.0 & 0.58 & 3.4 & 9.3 \\
\hline $\mathrm{Sr}$ & 4,200 & 2.3 & -- & 16.0 & 75.0 & 6.5 & 14.0 & 6.5 & 20.0 & 0.56 & 2.8 & 11 \\
\hline $\mathrm{Te}$ & 24 & 8.3 & 8.0 & 8.0 & 4.5 & 0.78 & 0.12 & 0.43 & 0.40 & 0.15 & 0.00 & 0.41 \\
\hline $\mathrm{Ti}$ & 15,000 & 2.6 & 2.1 & 1.8 & 130.0 & 3.7 & 89.0 & 10.0 & 0.02 & 0.02 & $0.0 \xi$ & 13 \\
\hline $\mathrm{Zr}$ & 9,400 & 0.43 & 0.72 & 1.9 & 0.01 & 0.01 & 0.01 & 0.01 & 0.01 & 0.01 & 0.01 & 0.01 \\
\hline
\end{tabular}


TABLE A.62. Cyclonic Melter Aerosol Size Analysis

\begin{tabular}{|c|c|c|c|c|c|c|}
\hline \multirow[b]{2}{*}{ Date } & \multirow[b]{2}{*}{ Period } & \multirow{2}{*}{$\begin{array}{c}\text { Feed Rate, } \\
\mathrm{kg} / \mathrm{min}\end{array}$} & \multicolumn{4}{|c|}{ Weight Percent } \\
\hline & & & $16 \mu \mathrm{m}$ & $6 \mu \mathrm{m}$ & $1 \mu \mathrm{m}$ & $\langle 1 \mu \mathrm{m}$ \\
\hline $5 / 1 s$ & $1645-1806$ & 1.1 & 7.6 & 4.0 & 9.4 & 79.0 \\
\hline $5 / 21 / 82$ & $0542-0729$ & 1.2 & 7.3 & 2.5 & 9.4 & 80.8 \\
\hline
\end{tabular}

off-gas system, which reduced overall melter emission performance (DF). However, the fact that the scrubber DF increased during this same period suggests that melter sparging must generate larye-diameter aerosols which are easily removed by the close-coupled ejector venturi. Moreover, the overall system DF (melter + scrubber) during sparging is not significantly different than during nonsparging periods, which further reinforces the above argument.

The PSCM-7 melter test was distinguished by very low inleakage rates (10 to $15 \mathrm{scfm})$. Moreover, since this test did not employ lid heaters, plenum oxidation rates of combustible gases were quite slow. As a result, very high concentrations of $\mathrm{H}_{2}$ and $\mathrm{CO}$ were generated by the melter throughout the test as is clearly shown in Figure A.76. Although $C 0$ presented no particular off-gas problem, melter exhaust stream dilution was required to maintain $\mathrm{H}_{2}$ below $70 \%$ of its lower flammability limit. The peak concentration of $\mathrm{H}_{2}$ recorded during this test was $3.5 \%$.

After PSCM-7, molten salt samples were skimmed from the glass surface of the melter. Samples were taken four times on different days to determine the fate of the salt layer. The weight and molar percents for each element are shown in Table A.66. The salt layer diminished with time, and the last sample taken on 6/08 was very difficult to obtain. The last two samples may have had some glass mixed in with the salt, so only the leachable constituents are reported. The salt layer appears to volatilize and, in a few weeks, is almost indistinguishable from the molten glass. The chloride salts disappear first. The majority of the salt layer appears to be $\mathrm{Na}_{2} \mathrm{SO}_{4}$. An attempt to match up cations and anions is shown in Table A.67, where $\mathrm{Na}$ was combined with sulfates, where possible. 
TABLE A.63. Elemental Distribution Across Cyclonic Size Fractions

Elemental Distribution, \%

\begin{tabular}{|c|c|c|c|c|c|c|c|c|c|c|}
\hline & \\
\hline \multirow[b]{2}{*}{ ement } & & size $F r$ & ction & $19 / 82$ & & & Size & action & $5 / 31 / 82$ & \\
\hline & $16 \mu \mathrm{m}$ & $6 \mu \mathrm{m}$ & $1 \mu \mathrm{m}$ & $\leq 1 \mu \mathrm{m}$ & Cond. & $16 \mu \mathrm{m}$ & $6 \mu \mathrm{m}$ & $1 \mu \mathrm{m}$ & $\leq 1 \mu \mathrm{m}$ & Cond. \\
\hline$A 1$ & 67.0 & 10.2 & 20.8 & 2.1 & -. & 41.8 & 8.5 & 17.5 & 32.2 & -- \\
\hline B & 0.8 & 0.2 & 0.7 & 0.1 & 98.2 & 0.9 & 0.3 & 1.02 & 0.07 & 97.7 \\
\hline $\mathrm{Ba}$ & 49.5 & -- & 50.5 & -- & -- & 21.32 & 19.8 & 58.8 & -- & -- \\
\hline $\mathrm{Ca}$ & 34.2 & 11.4 & 44.2 & 10.2 & $\cdots$ & 31.28 & 13.53 & 43.6 & 8.9 & 2.6 \\
\hline $\mathrm{Cd}$ & 1.7 & 1.4 & 4.7 & 92.3 & -- & 1.9 & 2.6 & 5.9 & 89.6 & -- \\
\hline $\mathrm{Cl}$ & 1.0 & 0.8 & 3.1 & 26.0 & 69.1 & 2.1 & 2.4 & 4.9 & 46.7 & 43.9 \\
\hline Co & 7.3 & -. & 12.4 & 80.3 & -- & 5.8 & 5.1 & 9.4 & 79.7 & -- \\
\hline $\mathrm{Cr}$ & 22.9 & 5.2 & 9.7 & 6.7 & 55.4 & 29.3 & 19.0 & 10.6 & 22.5 & 18.5 \\
\hline Cs & 1.3 & 1.3 & 4.6 & 92.8 & -- & 1.2 & 1.5 & 3.7 & 93.6 & -- \\
\hline $\mathrm{Cu}$ & 5.2 & 3.8 & 10.2 & 78.0 & 2.8 & 7.6 & 3.8 & 9.9 & 78.7 & -- \\
\hline Dy & 41.4 & 9.7 & 48.8 & -. & -- & 35.9 & 12.7 & 51.4 & -- & -- \\
\hline$F$ & 1.2 & 0.7 & 2.5 & 14.9 & 80.6 & 0.8 & 0.9 & 1.9 & 13.2 & 83.1 \\
\hline $\mathrm{Fe}$ & 30.2 & 10.5 & 46.8 & 9.0 & 3.6 & 28.1 & 12.8 & 48.3 & 6.6 & 4.2 \\
\hline La & 31.2 & 11.1 & 47.5 & 10.3 & -- & 29.8 & 13.6 & 52.2 & 4.4 & -- \\
\hline Li & 6.7 & 2.2 & 8.3 & 82.8 & -. & 6.7 & 3.8 & 8.8 & 80.7 & -. \\
\hline Mg & 58.6 & 8.1 & 33.3 & -. & .- & 59.3 & -- & 40.7 & -- & -- \\
\hline$M n$ & 34.3 & 10.9 & 45.5 & 7.2 & 2.0 & 32.2 & 14.0 & 47.0 & 6.2 & 0.6 \\
\hline Mo & 56.6 & -. & 43.4 & -- & -- & 24.5 & -- & 12.0 & 63.4 & -. \\
\hline $\mathrm{Na}$ & 2.8 & 1.6 & 5.8 & 89.8 & -. & 3.2 & 2.9 & 5.6 & 88.3 & -- \\
\hline $\mathrm{Nd}$ & 32.6 & 9.5 & 47.6 & 10.3 & -- & 29.4 & 11.2 & 46.4 & 13.0 & -- \\
\hline $\mathrm{Ni}$ & 21.7 & 8.3 & 25.6 & 18.0 & 26.4 & 27.9 & 13.1 & 26.4 & 21.8 & 10.8 \\
\hline $\mathrm{P}$ & 8.3 & -- & -- & 91.7 & -- & -. & -- & -- & -- & -- \\
\hline$P D$ & 1.5 & 1.4 & 5.9 & 91.1 & -- & 3.3 & 3.0 & 9.0 & 84.7 & -- \\
\hline S & -- & -- & 0.2 & 0.7 & 99.1 & -- & 0.1 & 0.3 & 1.0 & 98.6 \\
\hline Sb & 19.1 & 3.0 & 13.1 & 64.8 & -- & 9.8 & 5.2 & 9.0 & 76.0 & -- \\
\hline $\mathrm{Se}$ & 9.0 & 4.9 & 6.9 & 79.3 & -- & 8.6 & 9.1 & 15.8 & 66.5 & -- \\
\hline $\mathrm{Si}$ & 53.3 & 9.7 & 27.9 & 5.4 & 3.7 & 47.7 & 13.8 & 27.1 & 5.1 & 6.2 \\
\hline $\mathrm{Sr}$ & 38.9 & 11.5 & 49.6 & -. & -- & 27.5 & 13.6 & 25.9 & 33.1 & -- \\
\hline $\mathrm{Te}$ & 10.0 & 6.6 & 31.0 & 52.4 & - & 1.8 & 2.5 & 7.2 & 88.5 & -. \\
\hline $\mathrm{Ti}$ & 13.4 & 35.0 & 34.3 & 17.3 & -- & 29.4 & 6.5 & 13.2 & 50.8 & -- \\
\hline $\mathrm{Zn}$ & 1.5 & 1.0 & 2.9 & 84.7 & 9.8 & 9.6 & 3.8 & 23.5 & 22.3 & 40.9 \\
\hline $\mathrm{Zr}$ & 54.7 & 14.6 & 19.9 & 10.8 & $\ldots$ & 48.3 & 15.2 & 29.7 & 6.8 & -- \\
\hline
\end{tabular}


TABLE A.64. PSCM-7 Close-Coupled Scrubber Particulate DFs

\begin{tabular}{|c|c|c|c|c|}
\hline \multirow[b]{2}{*}{ Element } & \multicolumn{4}{|c|}{ DFs } \\
\hline & $5 / 18$ & $5 / 20$ & $5 / 21$ & Avg. \\
\hline$A 1$ & -- & 2.0 & 160 & 81 \\
\hline$B$ & 1.9 & 1.7 & 12 & 5.2 \\
\hline $\mathrm{Ba}$ & -- & 1.0 & -- & -- \\
\hline $\mathrm{Ca}$ & 50 & 32 & 190 & 90 \\
\hline $\mathrm{Cd}$ & 17 & 19 & 21 & 19 \\
\hline Co & -- & 36 & -- & 36 \\
\hline $\mathrm{Cr}$ & 33 & -- & 32 & 32 \\
\hline Cs & 17 & 17 & 21 & 18 \\
\hline $\mathrm{Cu}$ & 23 & 16 & 22 & 20 \\
\hline $\mathrm{F}$ & 11 & 10 & 12 & 11 \\
\hline $\mathrm{Fe}$ & 350 & 43 & 400 & 260 \\
\hline $\mathrm{La}$ & -- & 14 & 90 & 52 \\
\hline $\mathrm{Li}$ & 20 & 22 & 29 & 23 \\
\hline $\mathrm{Mn}$ & 430 & 410 & 560 & 470 \\
\hline $\mathrm{Na}$ & 17 & 20 & 24 & 20 \\
\hline $\mathrm{Nd}$ & -- & -- & 140 & 140 \\
\hline $\mathrm{Ni}$ & 82 & 46 & 220 & 120 \\
\hline $\mathrm{Pb}$ & 2.7 & 16 & 20 & 12 \\
\hline$S$ & 12 & 3.3 & 7.7 & 7.7 \\
\hline $\mathrm{Sb}$ & 19 & 27 & 24 & 23 \\
\hline Se & 17 & 3.0 & 3.6 & 7.9 \\
\hline Si & 200 & 25 & 330 & 180 \\
\hline$S r$ & -- & 9.1 & -- & 9.1 \\
\hline $\mathrm{Te}$ & 19 & 15 & 9.3 & 14 \\
\hline $\mathrm{Ti}$ & -- & 6.1 & 21 & 13 \\
\hline $\mathrm{Zn}$ & 4.1 & 23 & 43 & 23 \\
\hline $\mathrm{Zr}$ & 49 & 9.1 & 51 & 36 \\
\hline
\end{tabular}

PSCM-8 - JUNE 1982

PSCM-8 was a boosted 232-h test which utilized a new slurry feed composition possessing a higher alumina and lower iron content than the standard feed formulation. This new feed was expected to produce a higher viscosity ylass than observed with Frit-165. Since both feed and glass alterations might be expected to affect the effluent characteristics of the slurry-fed melter, off-gas studies were of special interest during the test. 
TABLE A.65. PSCM-7 Gross Aerosol DFs

\begin{tabular}{|c|c|c|c|c|c|}
\hline \multicolumn{2}{|c|}{ Sampling Period } & \multirow{2}{*}{$\begin{array}{c}\text { Sample } \\
\text { Type }\end{array}$} & \multirow{2}{*}{$\begin{array}{c}\text { Feed Rate, } \\
\mathrm{kg} / \mathrm{min}\end{array}$} & \multicolumn{2}{|c|}{ DF } \\
\hline Date & Interval & & & Melter & Scrubber \\
\hline $5 / 18$ & $1755-2033$ & Scrub & 0.75 & 1100 & 8 \\
\hline $5 / 19$ & $1645-1806$ & Cyclo & 1.10 & 1300 & -- \\
\hline $5 / 20$ & $1442-1715$ & Scrub & 1.15 & 1100 & 9 \\
\hline $5 / 20$ & $1925-0446$ & HEPA & 1.1 & 1400 & -- \\
\hline $5 / 21$ & $0542-0723$ & Cyclo & 1.15 & 1300 & 10 \\
\hline $5 / 21(a)$ & $1620-1731$ & Scrub & 1.40 & 540 & 18 \\
\hline
\end{tabular}

(a) Sparge testing.

Because of its length, this experiment was a good test of the total melter off-gas system. The only difficulty encountered was associated with the buildup of entrained matter about the off-gas cooling spray nozzle (see Figure A.2). These spray nozzle accumulations restricted melter off-gas flow, which necessitated cleaning halfway through the PSCM-8 experiment. The soft, nonfused deposits were easily removed. Figure A.77 is a photograph of the spray nozzle deposits that had accumulated by the end of the PSCM-8 test. These deposits had formed after the mid-run cleaning operation. The only other off-gas-1ine depositions were found around line penetrations, and these were quite limited in size. Figure A.78 illustrates the unobstructed condition of the horizontal off-gas line between the melter and the close coupled scrubber at the end of the PSCM-8.

Although accumulations of melter entrained matter restricted melter offgas flow, the extent of effective entrainment was moderately low. Data from HEPA filtration of the entire melter exhaust stream was used to establish overall melter aerosol performance. This data appears in Table A.68.

Although this DF value for PSCM-8 is lower than that achieved in PSCM-7, it is quite respectable when compared to results obtained from all other PSCM tests utilizing formate feed.

Melter performance with respect to individual feed components was also established during PSCM-8. This data appears in Table A.69. The most startling aspect of data present in this table is the high DF values recorded for 


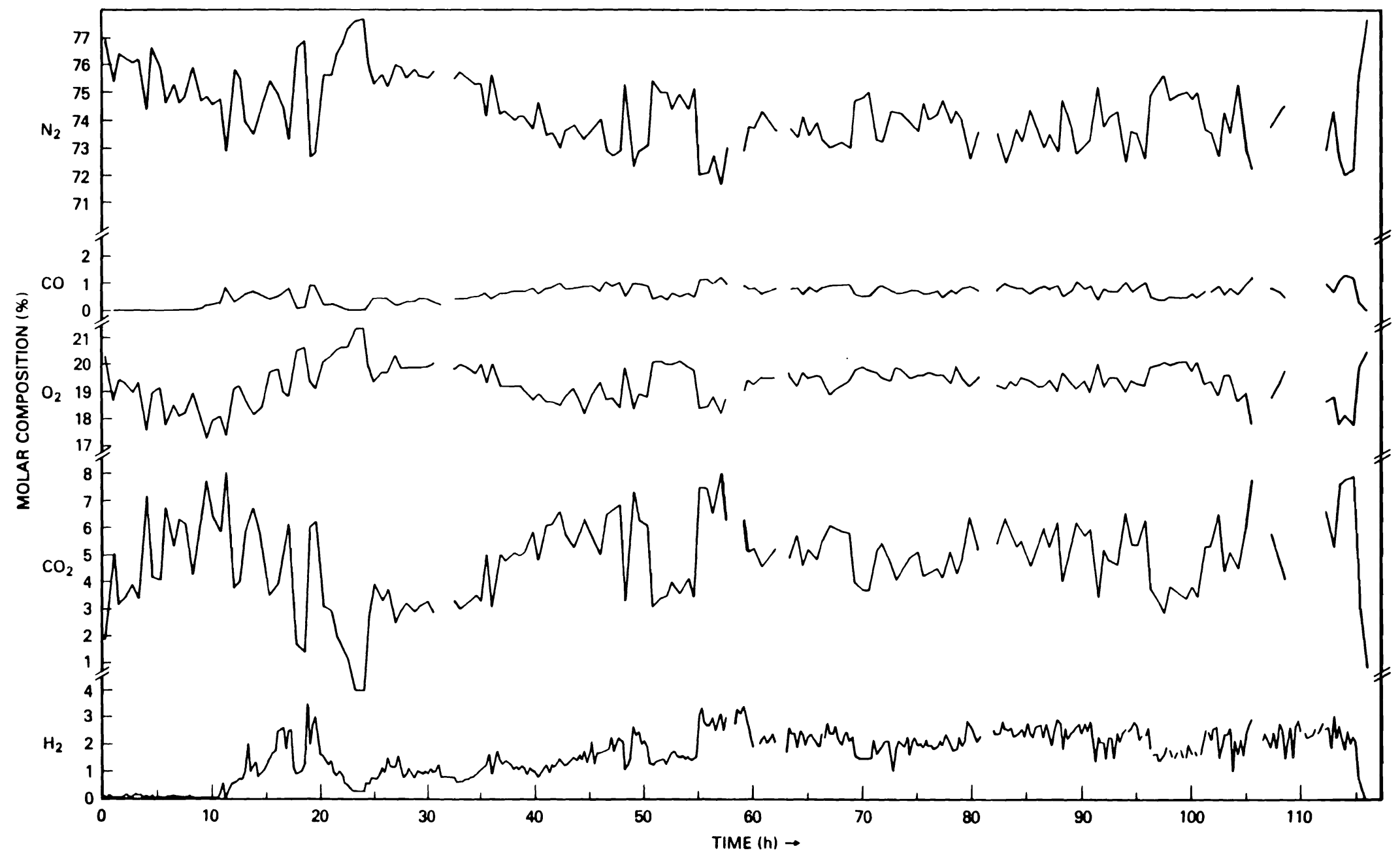

FIGURE A.76. PSCM-7 Off-Gas Composition 
TABLE A.66. Melter Surface Samples After PSCM-7

\begin{tabular}{|c|c|c|c|c|c|c|c|c|}
\hline \multirow[b]{2}{*}{ Element } & \multicolumn{2}{|c|}{$5 / 22 / 81$} & \multicolumn{2}{|c|}{$5 / 24 / 82$} & \multicolumn{2}{|c|}{$6 / 01 / 82$} & \multicolumn{2}{|c|}{$6 / 08 / 82$} \\
\hline & $W t \%$ & $M(a)$ & Wt\% & $M(a)$ & $W t \%$ & $M(a)$ & $\mathrm{Wt} \%$ & $M(a)$ \\
\hline B & 0.08 & 0.007 & 0.08 & 0.007 & 0.28 & 0.02 & 0.005 & -- \\
\hline $\mathrm{Ca}$ & 0.46 & 0.011 & 0.50 & 0.013 & 0.11 & 0.003 & 0.04 & 0.001 \\
\hline$C 1$ & 20.1 & 0.57 & 0.21 & 0.01 & 2.9 & 0.08 & 1.6 & 0.05 \\
\hline Cs & 0.13 & 0.001 & 0.05 & -- & -- & -- & -- & -- \\
\hline $\mathrm{F}$ & 0.73 & 0.04 & 0.20 & 0.01 & 0.28 & 0.02 & 0.19 & 0.01 \\
\hline $\mathrm{Li}$ & 3.4 & 0.49 & 3.7 & 0.53 & 4.0 & 0.58 & 0.35 & 0.05 \\
\hline $\mathrm{Na}$ & 28.2 & 1.22 & 25.5 & 1.11 & 26.8 & 1.16 & 25.7 & 1.12 \\
\hline$S$ & 49.6 & 0.52 & 71.2 & 0.74 & 62.8 & 0.65 & 70.0 & 0.73 \\
\hline$S \mathbf{i}$ & 0.04 & 0.001 & 0.04 & 0.001 & 2.8 & 0.10 & -- & -- \\
\hline $\mathrm{Sr}$ & 0.008 & -- & 0.02 & -- & 0.02 & -- & 0.005 & -- \\
\hline TOTAL & 2.86 & 2.42 & 2.61 & 1.96 & & & & \\
\hline
\end{tabular}

(a) $M=$ moles $/ 100$ grams.

TABLE A.67. Assumed Salt Compounds for PSCM-7, wt\%

\begin{tabular}{|c|c|c|c|c|}
\hline \multirow{2}{*}{$\begin{array}{l}\text { Elemental } \\
\text { Oxides }\end{array}$} & \multicolumn{4}{|c|}{ Weight Percent } \\
\hline & $5 / 22$ & $5 / 24$ & $6 / 01$ & $6 / 08$ \\
\hline $\mathrm{Na}_{2} \mathrm{SO}_{4}$ & 73.8 & 79.0 & 82.4 & 79.5 \\
\hline $\mathrm{NaCl}$ & 10.0 & -- & -- & -- \\
\hline $\mathrm{Li}_{2} \mathrm{SO}_{4}$ & -- & 20.0 & 7.7 & -- \\
\hline $\mathrm{LiCl}$ & 15.0 & 0.4 & 3.4 & 2.1 \\
\hline \multirow[t]{2}{*}{ LiF } & 0.5 & 0.2 & 0.5 & 0.2 \\
\hline & 0.5 & 1.0 & 2.3 & -- \\
\hline $\mathrm{SO}_{4}(\mathrm{a})$ & -- & -- & -- & 17.0 \\
\hline
\end{tabular}

(a) Ions with unknown counterpart.

Cs. PSCM-8 exhibited a CS DF a factor of 10 higher than the average obtained from all previous formate feed tests. In fact, the greatest formate feed CS DF recorded prior to the PSCM-8 test was 16, which was achieved during the nonboosted PSCM-4 experiment. Glass compositional data further reinforces this Cs off-gas data by reporting much higher Cs capacities than have been experienced 


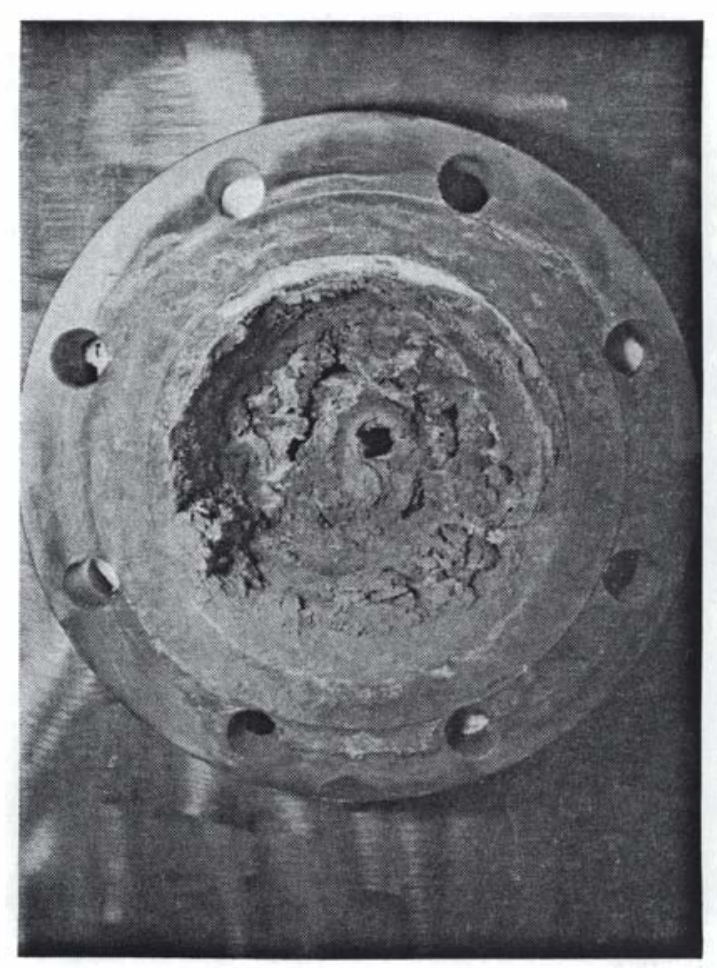

FIGURE A.77. Material Buildup in Melter Plenum Exhaust Port - Axial Hose was Where Spray Nozzle was Located

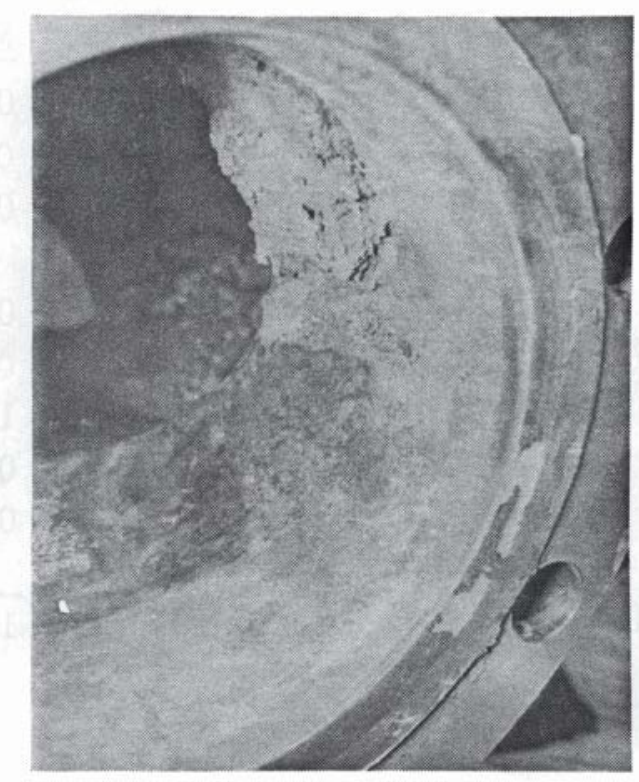

FIGURE A.78. Horizontal Off-Gas Line

TABLE A.68. Gross Melter Aerosol DF

$\frac{\text { Date }}{6 / 19-20} \quad \frac{\text { Interval }}{0447-1426} \quad \frac{\begin{array}{c}\text { Feed Rate, } \\ \mathrm{kg} / \text { min }\end{array}}{1.7} \quad \frac{\mathrm{DE}}{820}$

in the past. These results are quite exciting and have important implication if these results are reproducible. This new feed/glass formulation should be tested further.

The average melter feed component DFs listed in Table A.69 are compared with DFs collected from all previous melter tests in Table A.70. These results show that, with the exception of Cs, PSCM-8 exhibits rather average emission performance characteristics. 
TABLE A.69. PSCM-8 Particulate and Total Melter Feed Component DFs

\begin{tabular}{|c|c|c|c|c|c|c|c|c|c|c|}
\hline \multirow[b]{2}{*}{ Element } & \multicolumn{2}{|c|}{$6 / 17$} & \multicolumn{2}{|c|}{$6 / 18$ DFs } & \multicolumn{2}{|c|}{ 6/22 DFs } & \multicolumn{2}{|c|}{ 6/23 DFs } & \multicolumn{2}{|c|}{ Average DF } \\
\hline & Part & Total & Part & Total & Part & Total & Part & Iotal & Part & Total \\
\hline Al & 2600 & 2600 & 3100 & 3100 & 1795 & 1795 & 1100 & 1100 & 2200 & 2200 \\
\hline$B$ & 2900 & 150 & 2800 & 120 & 1800 & 1200 & 950 & 97 & 2100 & 390 \\
\hline $\mathrm{Ca}$ & 340 & 340 & 370 & 340 & 440 & 440 & 260 & 260 & 350 & 340 \\
\hline$c d$ & 4.8 & 4.8 & 3.8 & 3.8 & 5.0 & 5.0 & 8.8 & 8.8 & 5.6 & 5.6 \\
\hline $\mathrm{Cl}$ & 35 & 4.5 & 39 & 4.2 & 20 & 3.6 & 44 & 6.6 & 34 & 4.7 \\
\hline Cs & 120 & 120 & 86 & 86 & 72 & 72 & 250 & 250 & 130 & 130 \\
\hline $\mathrm{Fe}_{\boldsymbol{\theta}}$ & 630 & 630 & 640 & 640 & 640 & 640 & 380 & 380 & 570 & 570 \\
\hline La & 360 & 360 & 520 & 520 & 500 & 500 & 980 & 980 & 590 & 590 \\
\hline LI & 1700 & 1700 & 1500 & 1500 & 2100 & 2100 & 930 & 930 & 1600 & 1600 \\
\hline $\mathrm{Mg}$ & 1940 & 1940 & 2100 & 2100 & 1500 & 1500 & 660 & 660 & 1600 & 1600 \\
\hline Mn & 590 & 590 & 750 & 750 & 660 & 660 & 400 & 400 & 600 & 600 \\
\hline $\mathrm{Na}$ & 830 & 830 & 770 & 770 & 760 & 760 & 490 & 490 & 710 & 710 \\
\hline Nd & 400 & 400 & 500 & 500 & 450 & 450 & 790 & 790 & 540 & 540 \\
\hline $\mathrm{Ni}$ & 3600 & 3600 & 3700 & 3700 & 3000 & 3000 & 5900 & 5900 & 4000 & 4000 \\
\hline $\mathrm{s}$ & 20 & 12 & 16 & 9.7 & 30 & 14 & 13 & 7.3 & 19 & 10 \\
\hline Sb & 52 & 52 & 110 & 110 & 120 & 120 & 230 & 230 & 130 & 130 \\
\hline Se & 18 & 4.0 & 23 & 2.4 & 22 & 2.2 & 27 & 1.5 & 22 & 2.5 \\
\hline Si & 2600 & 2600 & 2600 & 2600 & 1600 & 1600 & 760 & 760 & 1900 & 1900 \\
\hline $\mathrm{Sr}$ & 560 & 560 & 570 & 570 & 670 & 670 & 390 & 390 & 550 & 550 \\
\hline $\mathrm{Te}$ & 6.6 & 6.6 & 8.3 & 8.3 & 6.2 & 6.2 & 9.5 & 9.5 & 7.6 & 7.6 \\
\hline $\mathrm{Ti}$ & 3300 & 3300 & 2200 & 2200 & 1300 & 1300 & 690 & 690 & 1900 & 1900 \\
\hline $\mathrm{Zr}$ & 2500 & 2500 & 2600 & 2600 & 1600 & 1600 & 700 & 700 & 1900 & 1900 \\
\hline
\end{tabular}

Size distributions of PSCM-8 aerosols established using a cyclonic sampliny system are summarized in Table A.71. As expected, the overall particle size distribution is bimodal. However, the small-diameter component of this distribution is not so heavily weighted as it was in PSCM-7. The usual differences in composition between the large- and small-diameter fractions are also present in PSCM-8 samples, as illustrated in Table A.72. Semivolatile aerosols are again found to be almost exclusively submicron. Selenium volatility is also suggested, but caution in interpretation is advised since this has not been observed previously, and since a new analytical technique for Se analysis was employed.

The off-gas performance of the close-coupled venturi ejector was also evaluated for melter-generated aerosols. Table A.73 presents scrubber DF values evaluated for individual aerosol feed components. The DFs obtained 
TABLE A.70. PSCM-8 Comparative DFs

\begin{tabular}{|c|c|c|c|c|c|c|c|c|c|c|c|c|c|}
\hline Element & $\begin{array}{l}\text { PSCM-8 } \\
\text { Avy. DF }\end{array}$ & $\frac{\text { PSCM-8 }}{\text { PSCM-7 }}$ & $\frac{\text { PSCM-8 }}{\text { PSCM-6 }}$ & $\frac{\text { PSCM-8 }}{\text { PSCM-5 }}$ & $\begin{array}{l}\text { PSCM-8 } \\
\text { PSCM-4 } \\
\end{array}$ & $\frac{\text { PSCM-8 }}{\text { LFCM-7 }}$ & $\frac{\text { DF }}{\text { PSCM-8 }}$ & $\frac{\text { Ratio }}{\frac{\text { PSCM-8 }}{\text { LFCM-6 }}}$ & $\frac{\text { PSCM-8 }}{\text { PSCM-2 }}$ & $\begin{array}{l}\text { PSCM-8 } \\
\text { LFCM-4 }\end{array}$ & $\begin{array}{l}\text { PSCM-8 } \\
\text { PSCM-1 } \\
\end{array}$ & $\frac{\text { PSCM-8 }}{\text { LFCM-3 }}$ & $\begin{array}{l}\text { PSCM-8 } \\
\text { LFCM-2 } \\
\end{array}$ \\
\hline Al & 2200 & 0.08 & 0.10 & 0.15 & 0.09 & 11 & 0.36 & 6.5 & 2.2 & 4.0 & 0.20 & 0.90 & 0.44 \\
\hline$B$ & 390 & 1.9 & 3.9 & 2.8 & 1.7 & 5.2 & 2.0 & 4.4 & 2.4 & 3.0 & 1.9 & 3.2 & 1.5 \\
\hline $\mathrm{Ca}$ & 340 & 0.13 & 0.29 & 0.31 & 0.18 & 5.6 & 0.31 & 1.9 & 0.57 & 1.3 & 0.19 & 0.19 & 0.47 \\
\hline $\mathrm{Cd}$ & 5.6 & 0.87 & 0.57 & 0.98 & 0.61 & 0.70 & -- & 0.07 & 0.12 & 0.08 & 0.03 & 0.07 & 0.02 \\
\hline $\mathrm{Cl}$ & 4.7 & 0.74 & 1.6 & 3.2 & 0.95 & -- & 1.2 & 1.8 & 1.6 & 2.2 & 1.5 & 0.53 & 0.28 \\
\hline Cs & 130 & 10.0 & 9.4 & 14 & 8.2 & 11 & 34 & 13 & 44 & 2.3 & 2.6 & 18 & 3.3 \\
\hline $\mathrm{Fe}$ & 570 & 0.21 & 0.32 & 0.52 & 0.29 & 8.3 & 0.36 & 2.5 & 0.84 & 2.2 & 0.15 & 0.83 & 1.4 \\
\hline La & 590 & 0.16 & 0.28 & 0.06 & -- & -- & - & - & -- & -- & -- & -- & -- \\
\hline Li & 1600 & 1.4 & 1.2 & 2.1 & 0.49 & 17 & 0.60 & 9.7 & 4.6 & 5.0 & 0.82 & 2.4 & 1.7 \\
\hline $\mathrm{Mg}$ & 1600 & 0.14 & 0.20 & 0.44 & -- & 12 & 0.19 & 6.0 & 1.7 & 4.4 & 0.17 & 0.86 & 3.2 \\
\hline$M n$ & 600 & 0.16 & 0.33 & 0.08 & 0.29 & 7.9 & 0.18 & 1.8 & 0.95 & 1.4 & 0.11 & 0.19 & 0.38 \\
\hline $\mathrm{Na}$ & 710 & 2.5 & 2.4 & 4.4 & 4.0 & 11 & 0.79 & 7.9 & 5.5 & 2.1 & 0.86 & 2.5 & 2.1 \\
\hline $\mathrm{Na}$ & 540 & 0.13 & 0.21 & -- & -- & - & - & -- & - & -- & -- & -- & -- \\
\hline $\mathrm{Ni}$ & 4000 & 1.3 & 3.7 & 7.0 & 2.9 & -- & 0.43 & 4.4 & -- & 15 & 2.7 & 9.4 & 9.4 \\
\hline$S$ & 10 & 3.8 & 2.0 & 2.4 & 0.67 & -- & 1.3 & 0.98 & 0.57 & 10 & 10 & 2.2 & 0.57 \\
\hline Sb & 130 & 0.18 & - & 0.29 & -- & 1.9 & -- & -- & 1.3 & 0.07 & -- & -- & 0.27 \\
\hline Se & 2.5 & 0.06 & -- & 0.02 & -- & 2.5 & -- & -- & -- & -- & -- & -- & 0.01 \\
\hline Si & 1900 & 0.22 & 0.15 & 0.36 & 0.21 & 15 & 0.63 & 6.8 & 1.2 & 4.5 & 0.13 & 0.73 & 2.0 \\
\hline $\mathrm{Sr}$ & 550 & 0.13 & 0.30 & -- & 2.2 & 1.0 & 0.86 & 1.9 & 0.86 & 2.7 & 0.07 & 0.37 & 1.4 \\
\hline Te & 7.6 & 0.31 & 2.6 & 2.5 & 2.5 & 1.4 & 0.24 & 0.04 & 0.13 & 0.12 & 0.05 & 0.03 & 0.13 \\
\hline$T i$ & 1900 & 0.12 & 0.32 & 0.26 & 0.21 & 15 & 0.45 & 11 & 1.3 & -- & -- & -- & 1.7 \\
\hline $\mathrm{Zr}$ & 1900 & 0.20 & 0.08 & 0.14 & 0.37 & -- & -- & - & -- & -- & -- & -- & -- \\
\hline
\end{tabular}


TABLE A.71. PSCM-8 Particulate Analysis of Melter-Generated Aerosols Sampling Period Weight Percent Versus Cut Point

\begin{tabular}{|c|c|c|c|c|c|}
\hline Date & Interval & $16 \mu \mathrm{m}$ & $6 p m$ & $1 \mu \mathrm{m}$ & $\leq 1 \mu \mathrm{m}$ \\
\hline $6 / 18$ & $0833-1004$ & 38.2 & 5.0 & 24.1 & 32.7 \\
\hline $6 / 21$ & $0815-1200$ & 41.2 & 7.3 & 21.1 & 30.4 \\
\hline $6 / 22$ & $2010-2301$ & 52.8 & 9.5 & 13.5 & 24.2 \\
\hline
\end{tabular}

during the present test are, on the average, much higher than those recorded during the previous PSCM-7 test. This is due to differences in both particle size and water loading. PSCM-8 generated larger aerosols and produced much higher off-gas water loadings [80\% versus 60\%] than did PSCM-7.

The size and composition of aerosols exiting the close-coupled off-gas scrubber were investigated using a scanning electron microscope (SEM). Figure A.79 shows the collected particulates under various degrees of magnification. Two filter samples were taken, corresponding to a low $(21 \mathrm{~L})$ and high $(120$ L) volume exposure. Unfortunately, both filters were too highly loaded to conduct a statistically significant particle size analysis. However, by comparing filter pore size $(0.2 \mu \mathrm{m})$ with impacted particulate matter at $10,000 \mathrm{x}$ magnification, it is clear that the particle size distribution of aerosols being carried downstream of the close-coupled scrubber is weighted quite strongly by submicron particulate matter. The composition and size of representative particles which are called out in Figure A.79 are detailed in Figure A.80. Clearly, the concept of average composition has no real meaning when dealing with individual particles.

Table A.74 summarizes the gross aerosol off-gas performance of both the PSCM melter and the close-coupled scrubber during PSCM-8. The deterioration of melter performance on $6 / 23$ was caused by unstable melter operation which occurred when the flow of feed was interrupted. The melter was not able to recover from this interruption and overfeeding resulted. As can be seen from Table A.74, the overall melter performance deteriorated, but the scrubber efficiency increased which acted to maintain the overall system performance. As in the sparging situation in PSCM-7, overfeeding apparently generates relatively large diameter aerosols which are easily removed by the close-coupled ejector venturi. 
TABLE A.72. PSCM-8 Elemental Distribution Across Cyclonic Fractions

\begin{tabular}{|c|c|c|c|c|c|c|c|c|c|c|c|c|c|c|c|c|}
\hline \multirow{3}{*}{\multicolumn{2}{|c|}{ Element }} & \multicolumn{15}{|c|}{ Elemental Distribution, $\%$} \\
\hline & & \multicolumn{5}{|c|}{ 6/18 Sample Fraction } & \multicolumn{5}{|c|}{ 6/21 Sample Fraction } & \multicolumn{5}{|c|}{ 6/22 Sample Fraction } \\
\hline & & $16 \mu \mathrm{m}$ & $6 \mu \mathrm{m}$ & $\underline{\mu m}$ & $\leq 1 \mu \mathrm{m}$ & Cond. & $16 \mu \mathrm{m}$ & $6 \mu \mathrm{m}$ & $\underline{\mu m}$ & $\leq 1 \mu \pi$ & Cond. & $16 \mu \mathrm{m}$ & $6 \mu \mathrm{m}$ & $I \mu m$ & $\leq 1 \mu \mathrm{m}$ & Cond. \\
\hline & Al & 80.3 & 10.3 & 9.0 & 0.3 & -- & 75.8 & 3.3 & 11.4 & 1.0 & 8.5 & 66.5 & 7.3 & 4.5 & 21.7 & -- \\
\hline & $\mathrm{Ba}$ & 88.5 & 11.5 & -- & - & -- & 66.1 & -- & 33.9 & -- & -- & 71.5 & 28.5 & -- & -- & -- \\
\hline & $\mathrm{Ca}$ & 29.5 & 8.0 & 43.7 & 18.8 & -- & 29.5 & 8.6 & 46.6 & 15.3 & -- & 39.0 & 13.5 & 30.1 & 17.0 & 0.4 \\
\hline & $c d$ & 18.0 & 3.5 & 14.6 & $<3.9$ & -- & 19.3 & 13.0 & 12.8 & 54.9 & -- & 36.9 & 9.4 & 14.5 & 39.2 & - \\
\hline & $\mathrm{Cl}$ & 0.9 & 0.3 & 1.4 & 8.0 & 89.4 & 1.5 & 0.5 & 0.7 & 3.7 & 93.7 & 2.6 & 1.2 & 1.1 & 5.8 & 89.3 \\
\hline & $\mathrm{Co}$ & -- & -- & 67.8 & 32.2 & -- & - & -- & -- & -- & -- & -- & -- & $-\infty$ & -- & -- \\
\hline & $\mathrm{Cr}$ & 61.5 & 1.0 & 24.3 & 13.2 & -- & 74.8 & $\cdots$ & 16.0 & 9.2 & -- & 54.3 & 9.7 & 11.1 & 24.9 & -. \\
\hline & Cs & 2.9 & 2.9 & 12.5 & 81.7 & -- & 4.4 & 7.5 & 13.6 & 74.5 & -- & 10.1 & 1.2 & 1.7 & 87.0 & -- \\
\hline & $\mathrm{Cu}$ & 37.0 & 8.0 & 39.1 & 15.9 & -- & 20.0 & 3.5 & 17.2 & 59.3 & -- & 22.4 & 10.8 & 49.7 & 17.1 & -- \\
\hline & Dy & 51.3 & -- & 48.7 & -- & -- & 66.1 & -- & 33.9 & -- & -- & 35.9 & 12.9 & 18.3 & 32.9 & -- \\
\hline & $\mathrm{Fe}$ & 57.6 & 12.7 & 27.4 & 2.0 & 0.3 & 63.2 & 1.4 & 35.4 & -- & -- & 41.2 & 13.6 & 13.6 & 31.6 & -- \\
\hline & $k$ & -- & -- & -- & -- & -- & -- & 3.5 & 67.4 & 29.1 & -- & -- & - & - & -- & -- \\
\hline & La & 51.5 & 9.4 & 39.1 & -- & -- & 54.3 & 5.4 & 40.3 & -- & -- & 33.9 & 12.2 & 15.1 & 38.8 & -- \\
\hline & $L i$ & 36.9 & 4.9 & 17.8 & '40.4 & -- & 46.0 & 9.4 & 17.3 & 27.3 & -- & 62.9 & 9.9 & 13.2 & 14.0 & -- \\
\hline & $\mathrm{Mg}$ & 56.4 & 2.2 & 30.9 & 10.5 & - & 61.4 & 2.1 & 34.1 & 2.4 & -- & 64.2 & 10.3 & 12.8 & 12.7 & -- \\
\hline & $M n$ & 56.9 & 12.7 & 30.0 & 0.4 & $-m$ & 58.5 & 2.0 & 38.9 & 0.6 & -- & 38.9 & 12.7 & 14.4 & 34.0 & -- \\
\hline & Mo & 12.7 & 0.8 & 48.3 & 38.2 & -- & 7.0 & 12.4 & 28.8 & 51.8 & -- & -- & -- & -- & -- & -- \\
\hline & $\mathrm{Na}$ & 17.5 & 3.6 & 20.6 & 58.3 & 0.1 & 21.1 & 15.2 & 18.3 & 45.3 & 0.1 & 31.0 & 5.7 & 13.7 & 49.5 & 0.1 \\
\hline & $\mathrm{Nd}$ & 47.0 & 3.4 & 49.6 & -- & -- & 48.9 & 4.3 & 37.7 & 9.1 & -- & 29.5 & 12.4 & 17.6 & 40.5 & -- \\
\hline & $\mathrm{Ni}$ & -- & 53.2 & -- & 46.8 & -- & -- & 14.4 & 72.5 & 13.1 & -- & 46.0 & 18.0 & 24.5 & 11.5 & -- \\
\hline & $\mathrm{Pb}$ & 27.1 & 1.8 & -- & 71.1 & -- & 8.3 & 13.0 & 2.5 & 76.2 & -- & 38.3 & 15.7 & 8.4 & 37.6 & -- \\
\hline & $S$ & 11.7 & 6.9 & 27.1 & 19.0 & 35.3 & 2.4 & 1.6 & 27.7 & 44.6 & 23.7 & 3.1 & 2.0 & 20.5 & 49.8 & 24.6 \\
\hline & Sb & 27.4 & 3.3 & 38.8 & 30.5 & -- & 18.3 & 38.7 & 27.7 & 15.3 & -- & 33.3 & 16.0 & 48.2 & 2.5 & -- \\
\hline & $\mathrm{Se}$ & 3.8 & 0.9 & 4.3 & -- & 91.0 & 0.6 & 0.1 & 0.4 & 73.3 & 25.6 & 1.4 & 0.4 & 1.1 & 9.5 & 87.7 \\
\hline & Si & 82.6 & 7.1 & 5.6 & 3.1 & 1.6 & 87.0 & 1.3 & 8.4 & 1.9 & 1.4 & 67.1 & 9.1 & 5.0 & 18.3 & 0.5 \\
\hline & $\mathrm{Sr}$ & 46.6 & 14.1 & 39.3 & -- & -- & 36.0 & 6.4 & 30.9 & 26.7 & -- & 44.1 & 13.2 & 22.5 & 20.2 & -- \\
\hline & Te & 7.0 & 1.0 & 14.2 & 77.8 & -- & 7.8 & 9.8 & 13.6 & 68.8 & -- & 16.2 & 8.0 & 27.4 & 48.4 & -. \\
\hline & $2 r$ & 81.1 & 6.9 & 6.3 & 5.7 & -- & 89.4 & -- & 7.8 & 2.8 & -- & 65.1 & 9.6 & 4.9 & 20.4 & -- \\
\hline
\end{tabular}


TABLE A.73. Particulate Melter Scrubber DFs

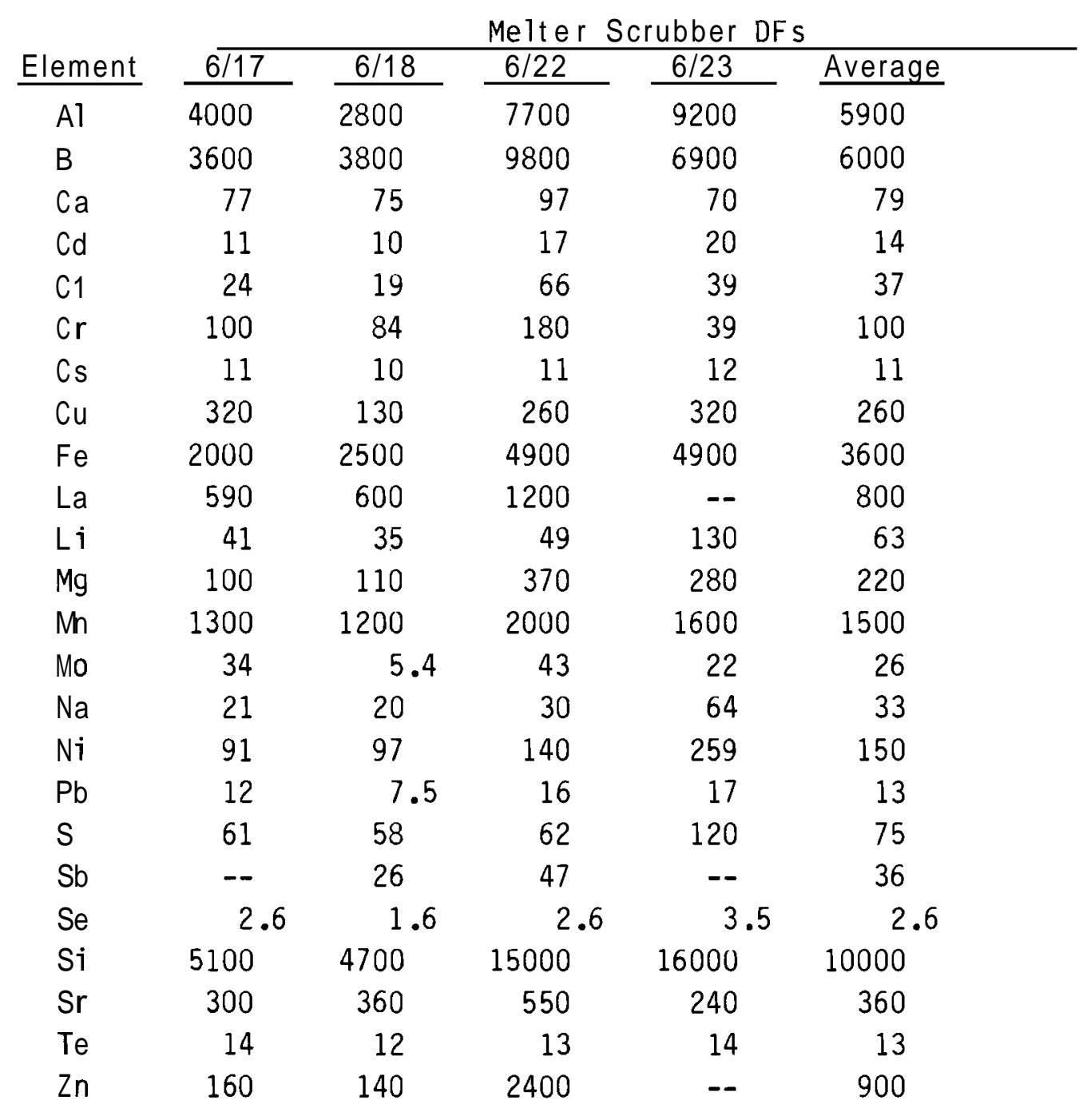

The compositional behavior of noncondensible melter exhaust components during the PSCM-8 experiment are graphically displayed in Figure A.81. Being a boosted test, exhaust concentrations of combustibles were quite low. Carbon monoxide was rarely over $0.5 \%$ and exhibited a maximum overall experiment maximum of only $-0.75 \% . \quad \mathrm{H}_{2}$ was hardly ever detectable.

However, large excursions in the concentrations of all noncondensible gases occurred during melter flow surges. The behavior of some of the more important melter off-gas stream components accompanying an excursion three times the average flow is detailed in Figure A.82. The off-gas behavior 
PSCM-8 LOW LOADING

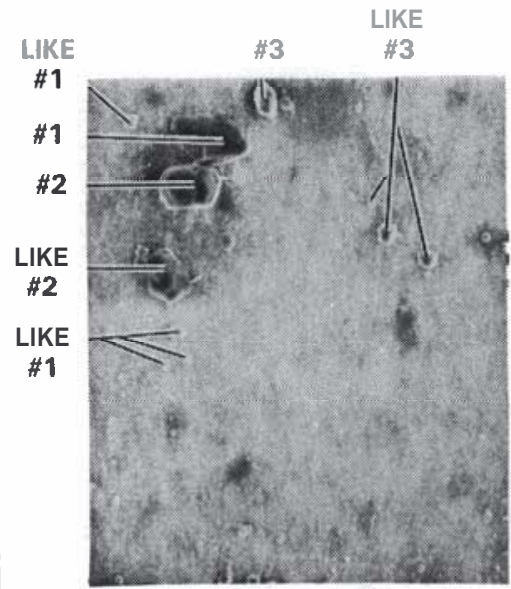

$300 x$

宫

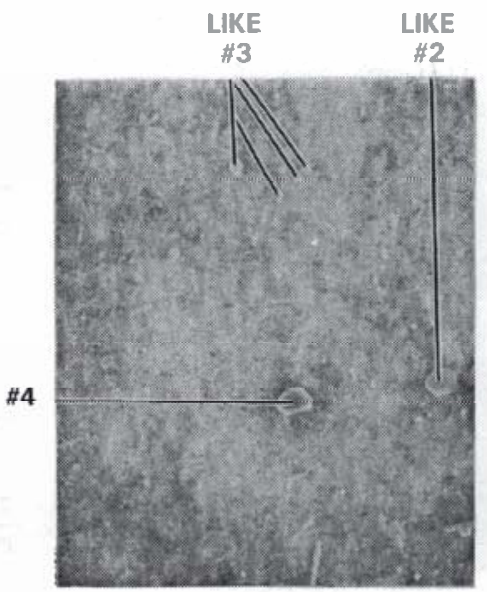

$1000 \mathrm{x}$

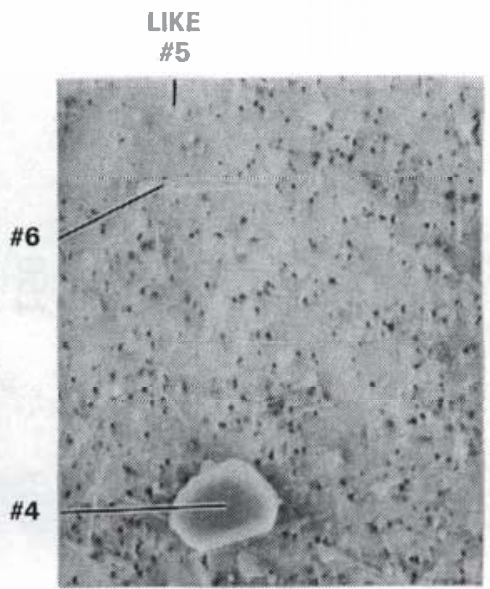

$3000 \mathrm{x}$

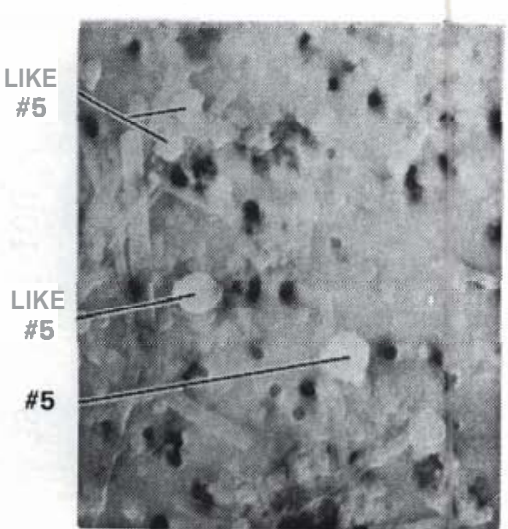

$10,000 x$

PSCM-8 HIGH LOADING

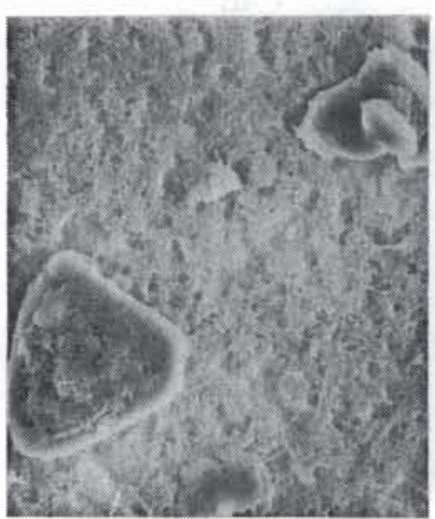

$1000 \mathrm{x}$

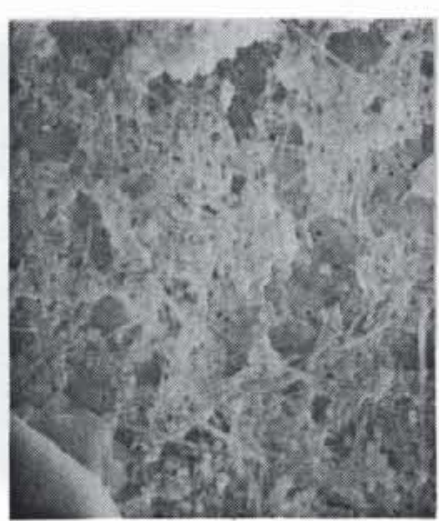

$3000 x$

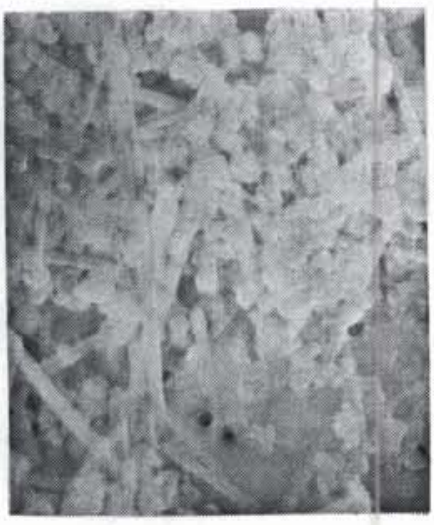

$10,000 \mathrm{X}$

FIGURE A.79. SEM Photographs of Particulate Samples Taken Downstream of the Close-Coupled Scrubber 

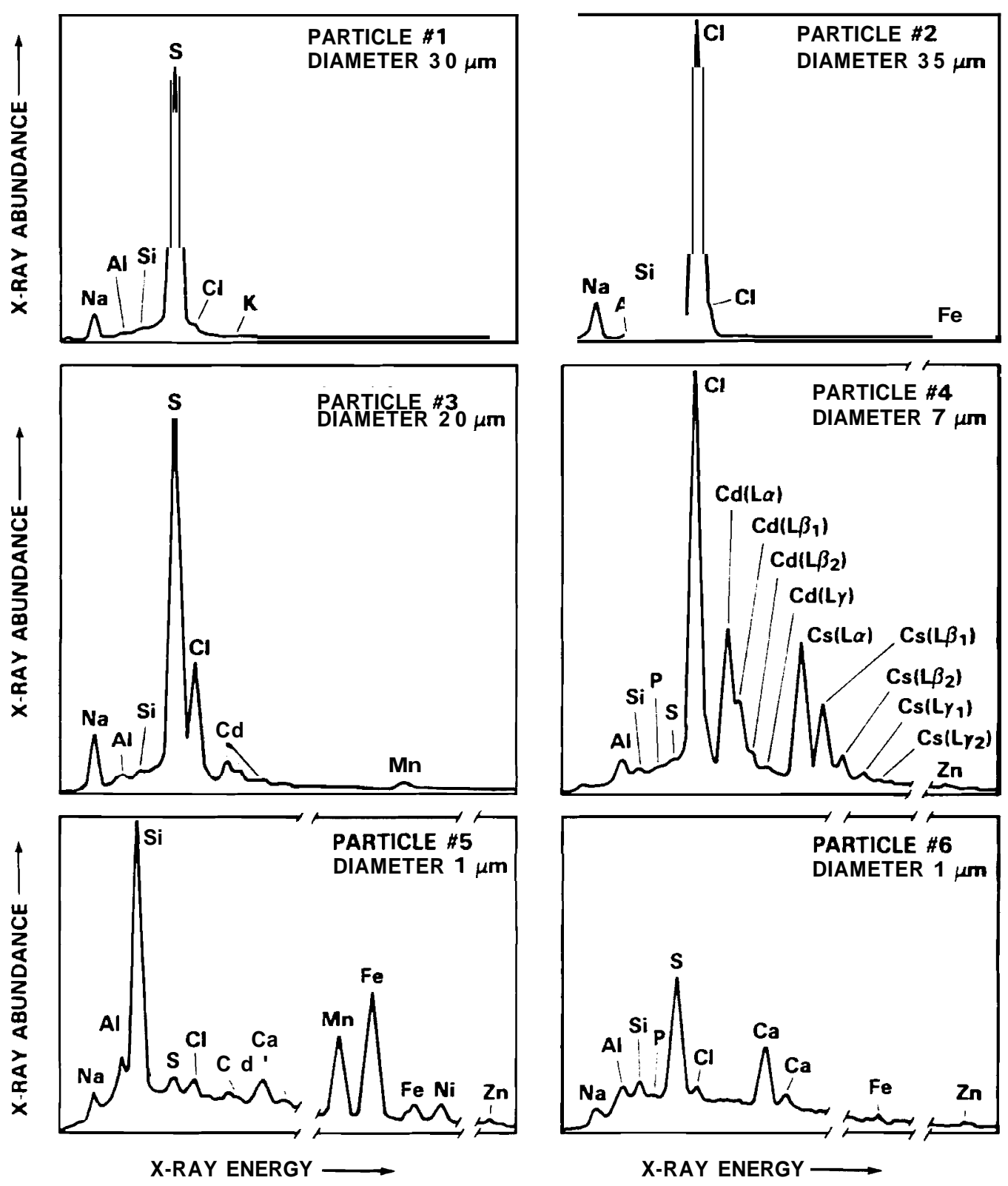

FIGURE A.80. X-Ray Fluorescence Spectra of Individual Particles Called Out in Figure A.79

exhibited in this figure is typical of all off-gas surging events observed during PSCM-8. However, caution should be used in interpreting the hydrogen spike in Figure A.82 because it may be due in part to a pressure fluctuation in the sampling line stimulated by the melter event. 
TABLE A.74. PSCM-8 Gross Aerosol DFs

\begin{tabular}{|c|c|c|c|c|c|}
\hline Sampl in & g Period & Sample & Feed Rate, & & $F$ \\
\hline Date & Interval & Type & $\mathrm{kg} / \mathrm{min}$ & Melter & Scrubber \\
\hline $6 / 17$ & $1017-1157$ & Scrub & 1.7 & 1100 & 67 \\
\hline $6 / 18$ & $0833-1004$ & Cyclo & 1.6 & 1200 & -- \\
\hline $6 / 18$ & $1143-1346$ & Scrub & 1.7 & 1100 & 44 \\
\hline $6 / 19-20$ & $0447-1426$ & HEPA & 1.7 & 820 & -- \\
\hline $6 / 21$ & $0815-1200$ & Cyclo & 1.7 & 1200 & -- \\
\hline $6 / 22$ & $1001-1327$ & Scrub & 2.0 & 950 & 51 \\
\hline $6 / 22$ & $2010-2301$ & Cyclo & 2.0 & 870 & -- \\
\hline $6 / 23$ & $0847-1436$ & Scrub & 1.7 & 580 & 110 \\
\hline
\end{tabular}

During the PSCM-6 run (see Section "PSCM-6 - MARCH 1982"), $\mathrm{SO}_{2}$ exhaust concentrations increased when feeding was terminated at the conclusion of the run, which suggested that $\mathrm{Na}_{2} \mathrm{SO}_{4}$ was accumulating within the melter. This was indeed found to be the case, as was later demonstrated in a post-run inspection of the idling melter glass surface. This stimulated speculation that accumulations of $\mathrm{Na}_{2} \mathrm{SO}_{4}$ could be responsible for changes in the melting capacity of liquid-fed melters that occur during the initial $24 \mathrm{~h}$ of liquid feeding (the startup phase). PSCM-8 melter emissions of $\mathrm{SO}_{2}$ further support this notion, as is shown in Figure A.83. During the initial feeding phase, when the melter's ability to handle feed was limited, feed-rate-normalized $\mathrm{SO}_{2}$ emission rates were uncharacteristically low, indicating that $\mathrm{Na}_{2} \mathrm{SO}_{4}$ was probably accumulating. As processing continued at a fixed feeding rate, $\mathrm{SO}_{2}$ emission rates yradually increased along with the melting capacity of the liquid-fed melter. Apparently a molten $\mathrm{Na}_{2} \mathrm{SO}_{4}$ phase aids in the feed melting process. 


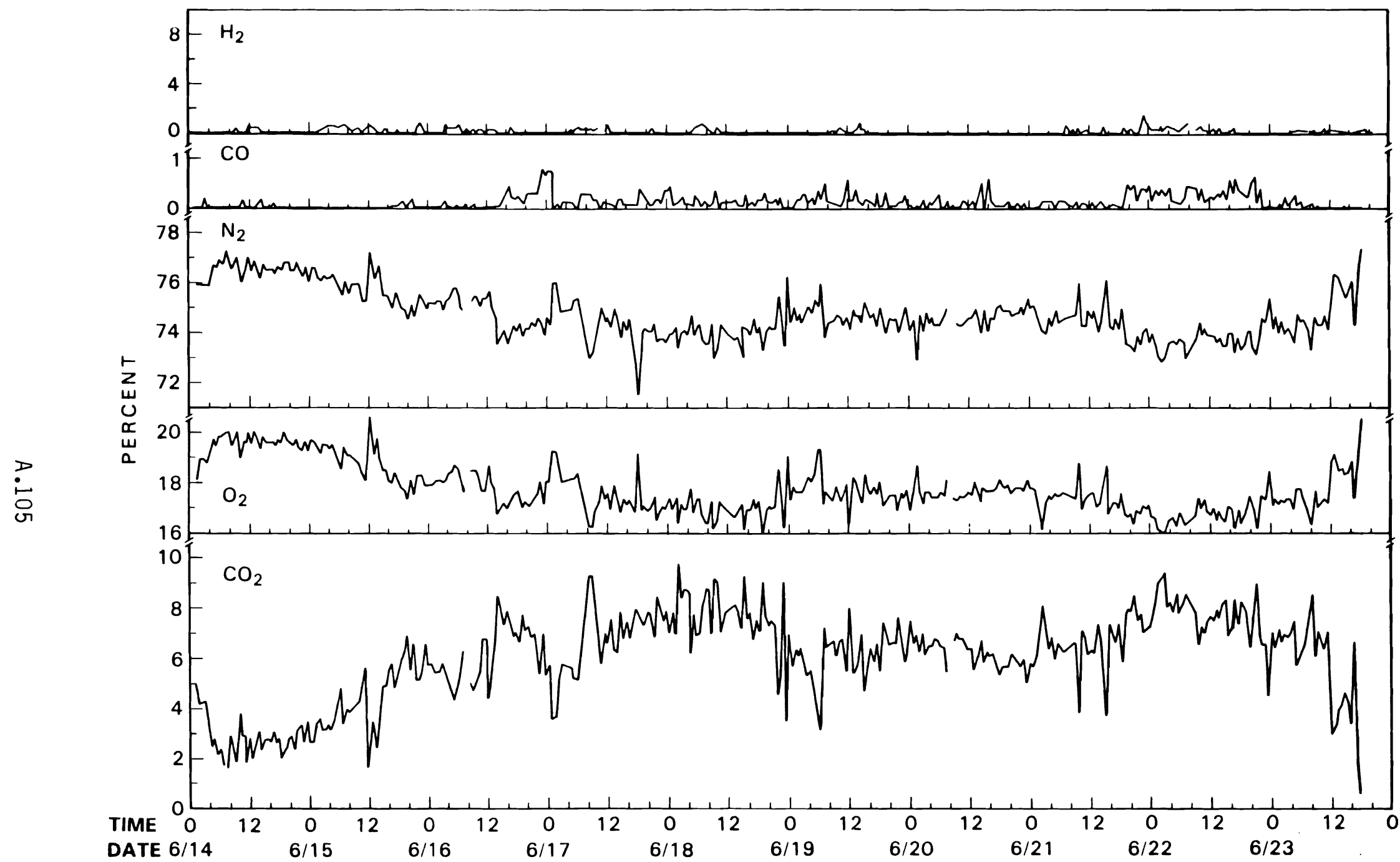

FIGURE A.81. PSCM-8 0ff-Gas Composition 


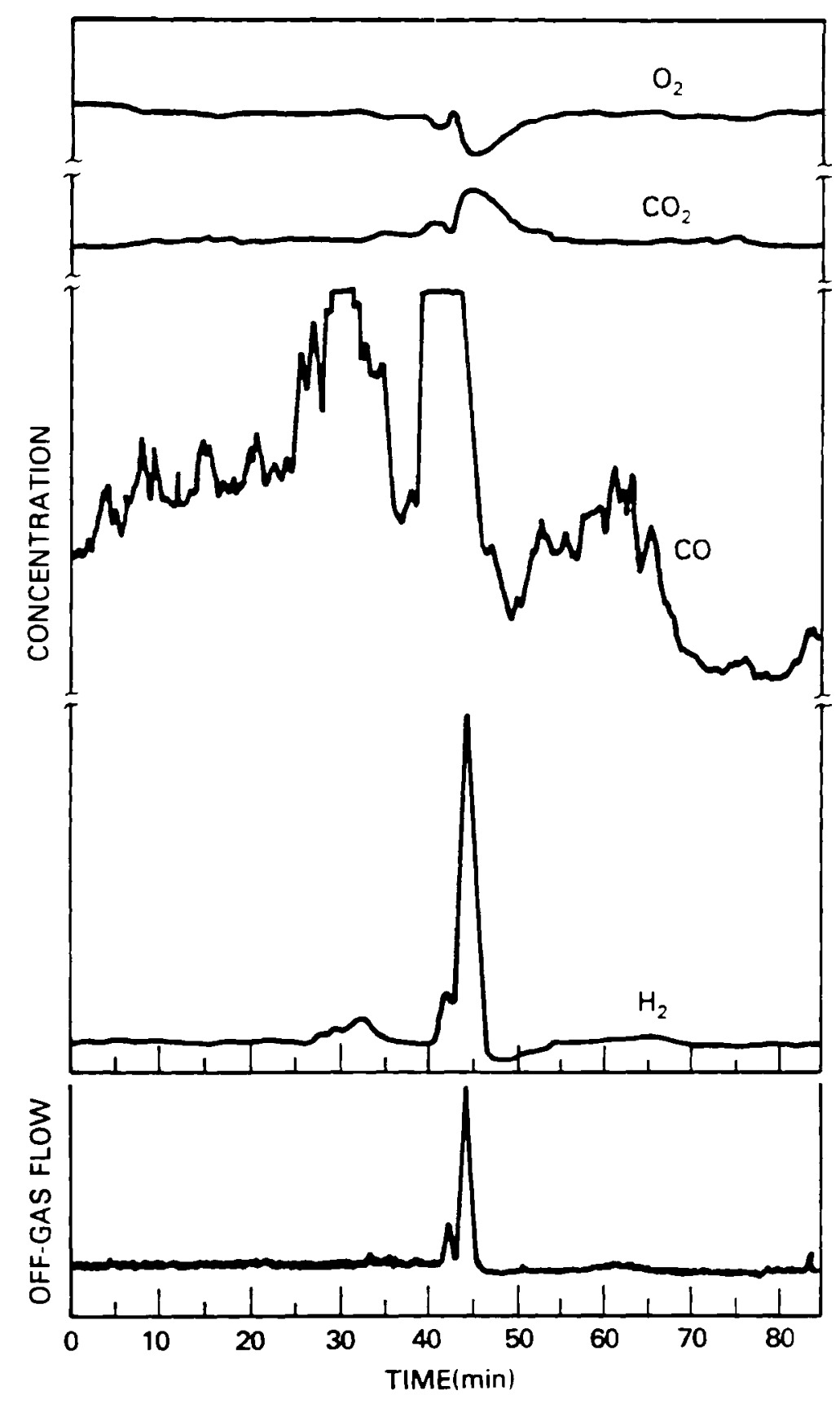

FIGURE A.82. Compositional Behavior of Noncondensible Melter Exhaust Gases Accompanying a Flow Surge. Maximum Extent of the Surge Event: Flow $3 \mathrm{X} ; \mathrm{H}_{2}<3.5 ; \mathrm{CO}>>0.5 \% ; \mathrm{CO}_{2} 15 \%$; $0_{2} 17 \%$ 


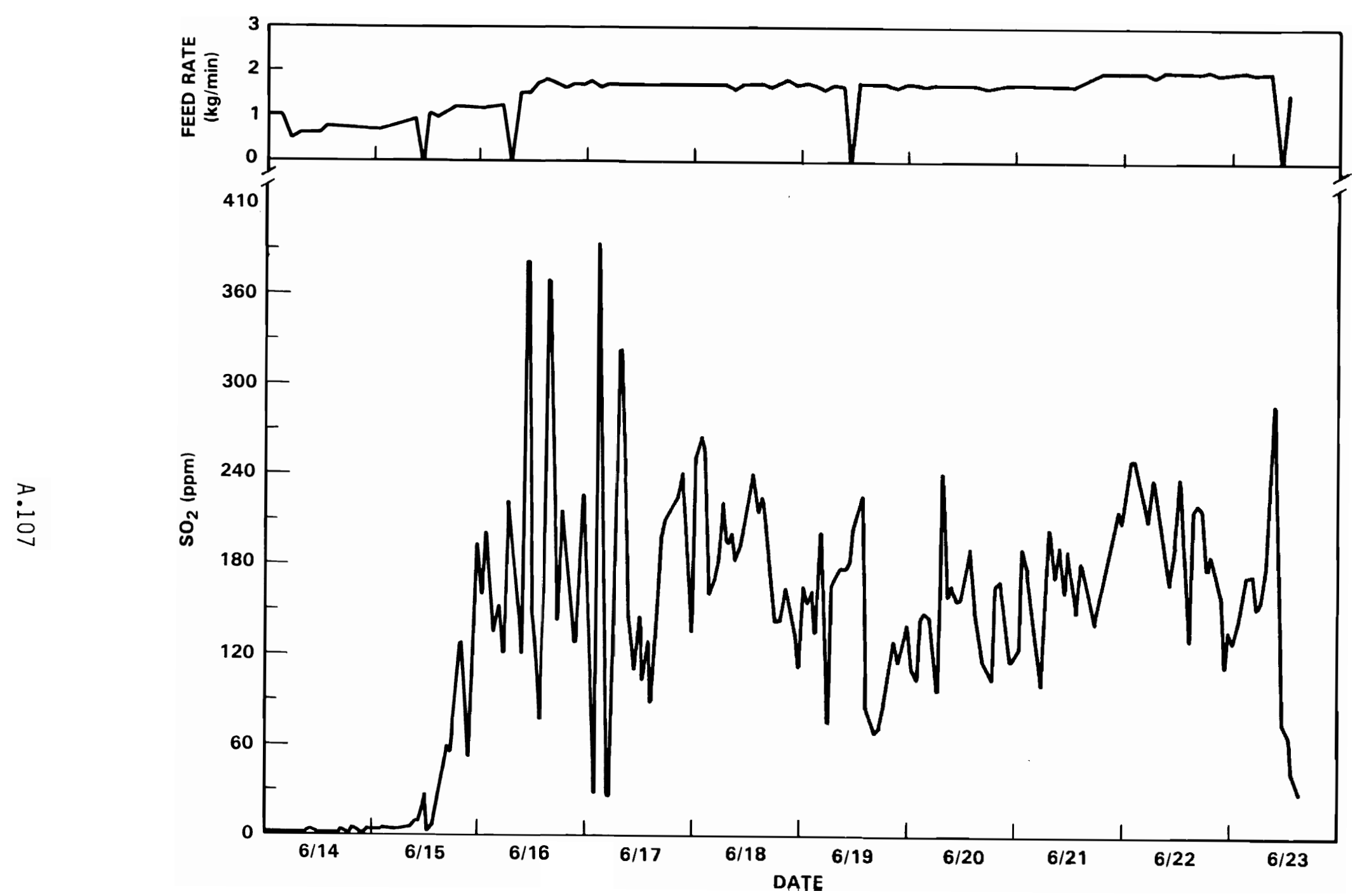

FIGURE A.83. Melter $\mathrm{SO}_{2}$ Emission haracteristics Accompanying $\sim 240-\mathrm{h}$ Test 
OFF-GAS RLW RATES

Flow rate behavior has been studied for all melter experiments (except PSCM-2) conducted since January 1, 1981. These include 1) two experiments (LFCM-4 and LFCM-6) utilizing a neutralized waste composition, 2) four tests (PSCM-3, LFCM-7, PSCM-4 and PSCM-5) involving the new formate feed composition, 3) two tests (PSCM-6 \& PSCM-7) employing a formate-feed composition and new frit, and 4) one test processing a high Al, low Fe formate feed. The results obtained from each test will now be discussed separately.

$\underline{\text { LFCM-4 - JANUARY } 1981}$

The off-gas flow rates of liquid-fed melters were first examined during the LFCM-4 experiment. What was observed was a noisy, erratic flow rate consisting of frequent suryes mixed with periods of relative calm. Portions of the strip-chart record generated by the flow transducer during this experiment are illustrated in Figure A.84. The conditions illustrated in this figure represent extremes within which the melter operations were maintained. A statistical analysis of the magnitude and duration of surging was conducted during an active 8 -h period of continuous melter operation. These results are summarized in Table A.75. The uncertainties listed with the averages represent one standard deviation of the data examined and, consequently, are measures of the spread or dispersion of this data (i.e., $68 \%$ of all data examined statistically lie within one standard deviation of the average).

During the LFCM-4 experiment, a significant number of off-gas surges exceeded the full-scale range of the flow transducer employed. These events were reexamined in order to extract information regarding their frequency, duration and extrapolated flows (triangular approximation). This data appears in Table A.76, where all emergency venting occurrences are so designated. It should be noted that conductance-1imiting restrictions involving loaded HEPA filters and/or valve throttliny of the system exhaust were responsible for the brief melter pressurizations that led to the emergency venting situations. The flows recorded during these melter pressurizations are probably not totally ascribable to the events which triggered the venting occurrence but, rather, 


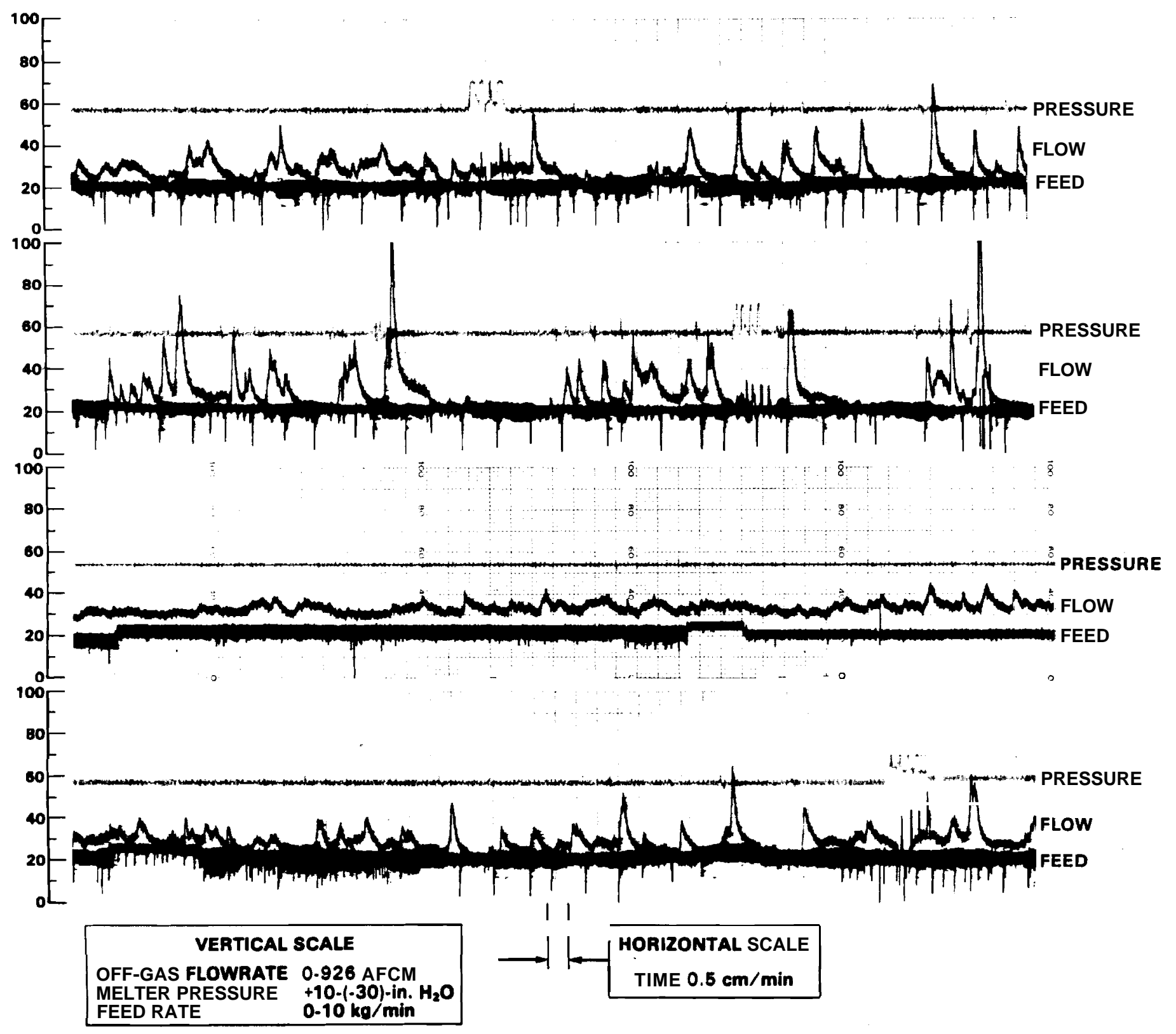

FIGURE A.84. LFCM-4 Off-Gas Flow Rate Behavior

are due (in part) to atmosphere flowback into the melter through the venting butterfly valve. This situation results primarily from the slow response time of the venting valve, coupled with an automated melter exhaust system that attempts to maintain a negative plenum pressure even when the melter is opened to the atmosphere. 
TABLE A.75. Flow Surging Characteristics During LFCM-4(a)

\begin{tabular}{ccc}
$\begin{array}{c}\text { Steady-State } \\
\text { Flow, scfm }\end{array}$ & $\begin{array}{c}\text { Average }(b) \\
\text { Surye Flow } \\
90, \text { scfm }\end{array}$ & $\begin{array}{c}\text { Average } \\
\text { Surge Duration } \\
\pm \sigma, \min \end{array}$ \\
\cline { 1 - 2 } & $\frac{2 \pm 1}{220 \pm 80}$ & $2 \pm 1$
\end{tabular}

(a) Study conducted over an 8 -h period on $1 / 22 / 81$.

(b) Total average flow (steady-state plus spike) is listed.

TABLE A.76. Frequency, Duration and Extent of LFCM-4 Surges

\begin{tabular}{|c|c|c|c|c|}
\hline Date & Time & $\begin{array}{c}\text { Duration, } \\
\min \end{array}$ & $\begin{array}{l}\text { Flow, } \\
\text { scfm }\end{array}$ & Vent \\
\hline \multirow[t]{4}{*}{$1 / 21 / 81$} & 1328 & 1.8 & 450 & Yes \\
\hline & 1600 & 2.4 & 450 & \\
\hline & 1655 & 3.0 & 450 & Yes \\
\hline & 1845 & 0.5 & 450 & \\
\hline \multirow[t]{10}{*}{$1 / 22 / 81$} & 1300 & 1.0 & 470 & \\
\hline & 1345 & 1.5 & 520 & \\
\hline & 1440 & 1.5 & 570 & Yes \\
\hline & 1505 & 1.0 & 500 & \\
\hline & 1515 & 3.2 & 450 & \\
\hline & 1700 & 3.2 & 450 & \\
\hline & 1815 & 3.2 & 450 & \\
\hline & 1820 & 2.7 & 580 & \\
\hline & 1948 & 3.2 & 590 & Yes \\
\hline & 2040 & 2.3 & 620 & Yes \\
\hline
\end{tabular}

LFCM-6 - JUNE 1981

One of the main objectives of the flow rate studies during LFCM-6 was to characterize the maximum flow surges generated by normal melter operation. Because off-gas surges extend beyond the dynamic range of the flow transducer employed during LFCM-4, a flow transducer was employed during the June run that responded to surge impulses but was relatively insensitive to the average flow rate. The maximum flow surges were cataloged and treated statistically. These 
results are summarized in Table A.77. It should be noted that no emergency venting occurred during this run. On the other hand, care was exercised to minimize conductance-limiting situations within the melter off-gas system.

\section{$\underline{\text { PSCM-3 - JULY } 1981}$}

The modest off-gas characteristics of the unboosted pilot-scale melter allowed both the average and surging flows to be characterized by a single offgas flow transducer. The data generated during PSCM-3 are summarized in Table A.78.

Melter flow rate behavior appears to have been drastically altered by the nature of the new formate feed. No longer is flow rate characterized by an erratic surging behavior; rather, a quiet, stable flow rate appears to be the dominant feature associated with steady-state melter operations.

LFCM-7 - AUGUST 1981

Due to the quiescent nature of PSCM-3 flow, a flow transducer capable of measuring the average flow rate was utilized in LFCM-7. It was hoped that the dynamic range of this transducer would be adequate for any surges which might be generated by this formate-fed, lid-boosted melter. This, indeed, did turn out to be the case, where only a single significant event occurred in $-120 \mathrm{~h}$ of melter operation. This event did cause melter pressurization, which initiated emergency venting. The maximum flow recorded during this event was a factor of 3 greater than the average flow. It should be noted that a partially-loaded

TABLE A.77. LFCM-6 Surging Flow Rate Behavior

$\frac{\begin{array}{c}\text { Mean Surge Flow, } \\ \text { scfm }\end{array}}{185} \quad \frac{\begin{array}{c}\text { Data Dispersion } \\ \text { scfm }\end{array}}{63} \quad \frac{\begin{array}{c}\text { Maximum Flow, } \\ \text { scfm }\end{array}}{465}$

TABLE A.78. PSCM-3 Flow Rate Behavior

$\frac{\text { Flow }(\mathrm{scfm})}{\frac{\text { Avg. }}{70}} \frac{\text { Max. }}{220} \quad \frac{\text { Surges a } \% \text { Average Flow }}{\frac{200}{11} \quad \frac{300}{2} \quad \frac{400}{0}}$


HEPA filter ( $\triangle P-10$ in.) was present in the off-gas line when this event occurred. In addition, the water present in a seal pot, which was blown into the hot off-gas line by the pressurization, accounted for some of the flow recorded during this event. A summary of all pertinent off-gas flow rate data generated during LFCM-7 appears in Table A.79.

\section{PSCM-4 - DECEMBER 1981}

During PSCM-4, the total off-gas flow was measured to characterize melter off-gas flow surges. The data collected are shown in Table A.80. It should be noted that 22 of the surges that were $>50 \%$ above the average flow occurred during a period when the melter surface was completely covered by a cold cap and when the melter seemed to be accumulating feed. The feed rate appeared to be higher than the melter's processing capabilities during that period. Later, the same feed rate was being processed with little surging, but the cold cap was not complete, and feed was not accumulating in the melter. These data indicate that frequent surges $>50 \%$ above average off-gas flow rate occur when the melter is being overfed.

TABLE A.79. LFCM-7 Flow Rate Behavior

\begin{tabular}{|c|c|c|c|}
\hline \multirow{2}{*}{\multicolumn{3}{|c|}{ Flow Rate, scfm }} & \multirow{3}{*}{$\frac{\text { Surges }}{\text { Maximum }}$} \\
\hline & & & \\
\hline M i nimum & Maximum & Average & \\
\hline 190 & 270 & 240 & 710 \\
\hline
\end{tabular}

TABLE A.80. Off-Gas Surging Behavior

\begin{tabular}{lcc}
\multicolumn{1}{c}{ Flow Characteristics } & Rate \\
\hline Average flow & & $70 \mathrm{scfm}$ \\
Maximum surge flow & $145 \mathrm{scfm}$ \\
Number of surges, $>150 \%$ average & & 26 \\
Average surge length & 4 minutes \\
Range of surge lengths & $0.5-8$ minutes \\
Maximum surge volume & $-1000 \mathrm{ft}^{3}$
\end{tabular}


PSCM-5 - JANUARY 1982

During the January PSCM-5 test, the off-gas flow was measured with a Ramapd target-type flowmeter. As the run progressed, the flowmeter collected deposits which affected the calibration of the instrument; however, the changes between readings are believed to be proportional. Surges in the off-gas flow were categorized by using the ratio of the surge to the average flow. The ratios were separated into stable and unstable operating periods, and these values are shown in Table A.81. The stable and unstable periods were identified by observation of the cold cap through the melter viewport. These data represent only the first two days of the PSCM-5 test due to flowmeter malfunctions. Off-gas flow chart recordings of stable and unstable periods are shown in Figure A.85. As can be seen, unstable periods are characterized by frequent high spikes in flow.

PSCM-6 - MARCH 1982

The off-gas flow rate was quite stable during most of PSCM-6. On March 21, the first day of the run, the melter was overfed because the glass temperatures were low. This overfeeding was responsible for all recorded offgas surges. This data is shown in Table A.82. The overfeeding situation described above was determined by visual observation of the melter cold cap. The unstable melter operation occurred between 0200 and 1100 hours on March 21 .

During steady-state operation, no off-gas surges occurred, and the Ramapo flowmeter recorded an average gas flow rate of $120 \mathrm{scfm}$. This flow rate

TABLE A.81. PSCM-5 Off-Gas Flow Rate Behavior

\begin{tabular}{|c|c|c|}
\hline Flow Characteristics & Stable & Unstable \\
\hline Maximum surge ratio & 1.8 & 2.9 \\
\hline Average surge ratio & 1.4 & 1.9 \\
\hline Average flow rate, $\operatorname{acfm}(a)$ & 180 & 180 \\
\hline Average surge duration, min & 3 & 3 \\
\hline Maximum surge duration, min & 15 & 5 \\
\hline
\end{tabular}

(a) Calculated average from feed rate with off gas at $400^{\circ} \mathrm{C}$. 
$\stackrel{\square}{0}$

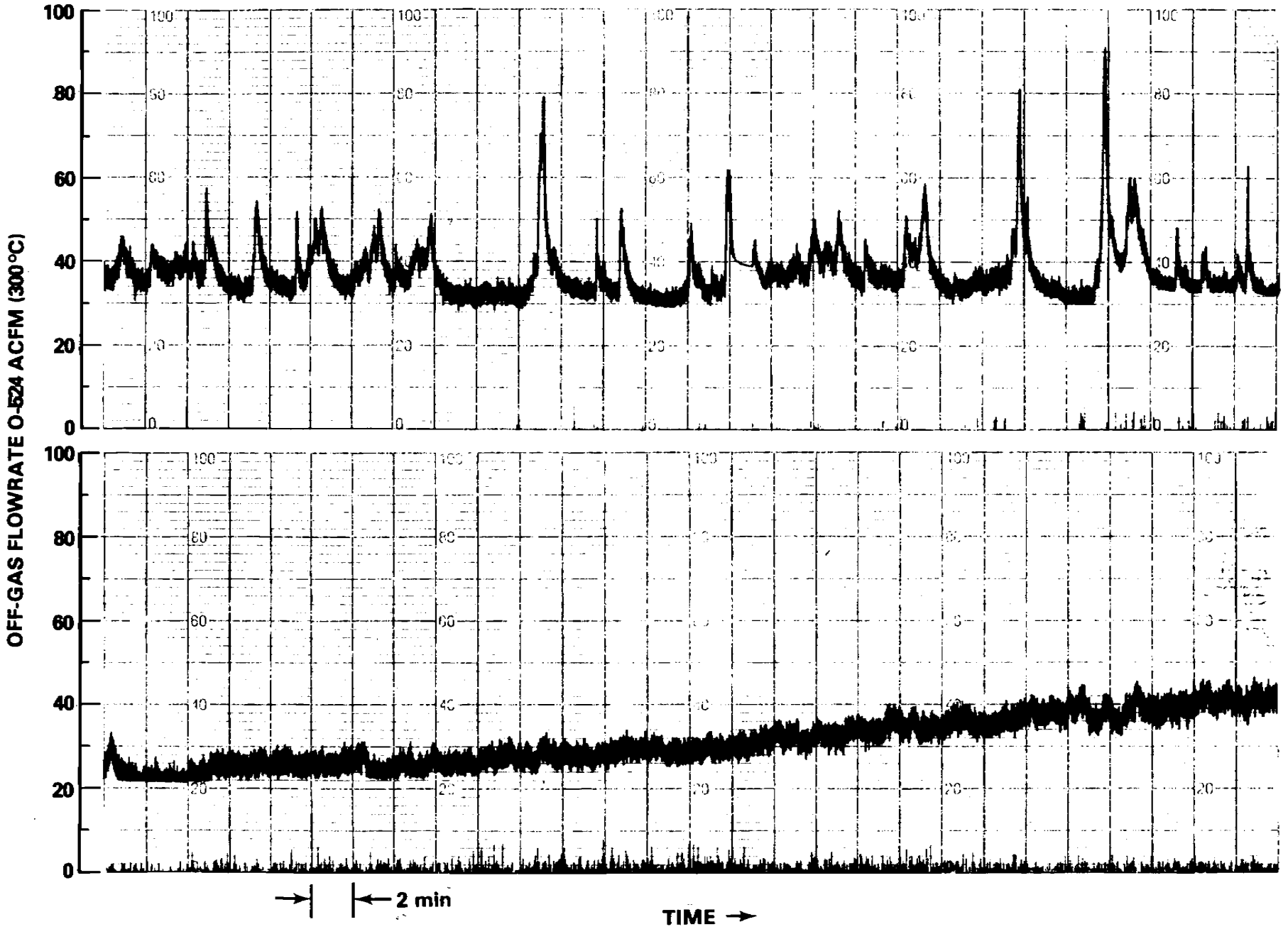

FIGURE A.85. PSCM-5 Off-Gas Flow Characteristics 
TABLE A.82. PSCM-6 Off-Gas Flow Characteristics

\begin{tabular}{ccccc} 
Flow, & scfm & & \multicolumn{2}{c}{$\begin{array}{c}\text { Surges, Greater than } \\
\text { Percent }\end{array}$} \\
& $\frac{\text { Maximum Average Flow }}{{ }_{80} \text { (a) }}$ & $\frac{150 \%}{7}$ & $\frac{200 \%}{4}$ & $\frac{300 \%}{0}$
\end{tabular}

(a) Average during period of surges

Feed rate 0 to $1.2 \mathrm{~kg} / \mathrm{min}$.

occurred with a slurry feed rate of $2 \mathrm{~kg} / \mathrm{min}$. The Ramapo flowmeter results were compared to a periodically checked pitot tube, which indicated an off-gas flow rate of $100 \mathrm{scfm}$. This indicates the Ramapo flowmeter gives reasonable values which might be slightly high because of the particulate in the off-gas lines.

The noncondensible gas flow was periodically measured with a pitot tube and calculated from the average $\mathrm{CO}$ and $\mathrm{CO}_{2}$ concentrations in the gas. The flow was calculated for seven different time periods representing the periods before and after the use of a sampling HEPA filter. The carbon content in the feed was used with feeding rate and $\mathrm{CO}+\mathrm{CO}_{2}$ exhaust concentration data to determine the total noncondensible gas flow. The results are shown in Table A.83.

The values calculated from both methods compare very well and indicate that a small leak is present in the HEPA filter holder. This leak would not affect HEPA filter results. The air-atomized water spray nozzle used to cool the off gas contributed -5 scfm to the noncondensible gas flow. The total inleakage into the melter was about 25 scfm.

PSCM-7 - MAY 1982

During PSCM-7, the total melter off-gas flow rate was monitored using the pressure drop across an orifice plate. The orifice was designed to detect and record large fluctuations in the off-gas flow rate. A graphical display of this flow data is shown in Figure A.86. This graph is a qualitative index of the off-gas flow rate instabilities and is compared to the melter operational stability index also shown in Figure A.86. Overall, there were $>150$ surges in PSCM-7; most of them occurred near the beginning of the test. 
TABLE A.83. Noncondensible Gas Flow (scfm)

\begin{tabular}{|c|c|c|c|c|}
\hline Date & Time & $\begin{array}{l}\text { Average } \\
\text { Pitot Tube } \\
\text { Reading } \\
\end{array}$ & $\begin{array}{c}\text { Calculated } \\
\text { From CO+CO2 } \\
\text { Concentrations } \\
\end{array}$ & $\begin{array}{r}\text { HEPA } \\
\text { Fi titer } \\
\text { Status } \\
\end{array}$ \\
\hline $3 / 23$ & $0033-2400$ & 30 & 28 & Out \\
\hline $3 / 24$ & $0036-1117$ & 45 & 48 & In \\
\hline $3 / 24$ & $1117-0100$ & NA & 30 & Out \\
\hline $3 / 25$ & $0132-2400$ & 33 & 31 & Out \\
\hline $3 / 25$ & $2024-2400$ & 41 & 43 & In \\
\hline $3 / 26$ & $0040-0302$ & NA & 33 & Out \\
\hline $3 / 26$ & $0302-1410$ & 30 & 35 & Out \\
\hline
\end{tabular}

The melter stability index is determined by feed rate and power input factors. The off-gas stability index is determined by counting the number of surges in a $1-h$ period, which exceeded two times the calculated average flow rate. If more than 10 surges were found, an index of 10 was given to that period. The section marked with "cyclone" may not be comparable to other areas because a particulate sampling cyclone placed in front of the orifice could have affected the orifice's operations. "Ramapo" indicates that the data were taken with a Ramapo flowmeter because the orifice flowmeter was bypassed at that time.

As a comparison, the off-gas flow rate stability(a) index during PSCM-6 was only above a value of two once, while the rest of the run had only a total of three surges. PSCM-6 was a much more stable test than was PSCM-7.

PSCM-8 - JUNE 1982

The total off-gas flow rate was monitored during PSCM-8 and is shown in Table A.84. An orifice flowmeter was used for most of the experiment, and a Ramapo flowmeter was used when a HEPA filter sample was being collected. The

(a) Currently, "stability" is a subjective decision made by the shift engineer, taking into consideration visual and recorded data and current melter behavior. The purpose of these analyses are to quantify a variable or measurement to use in place of subjective judgment. 


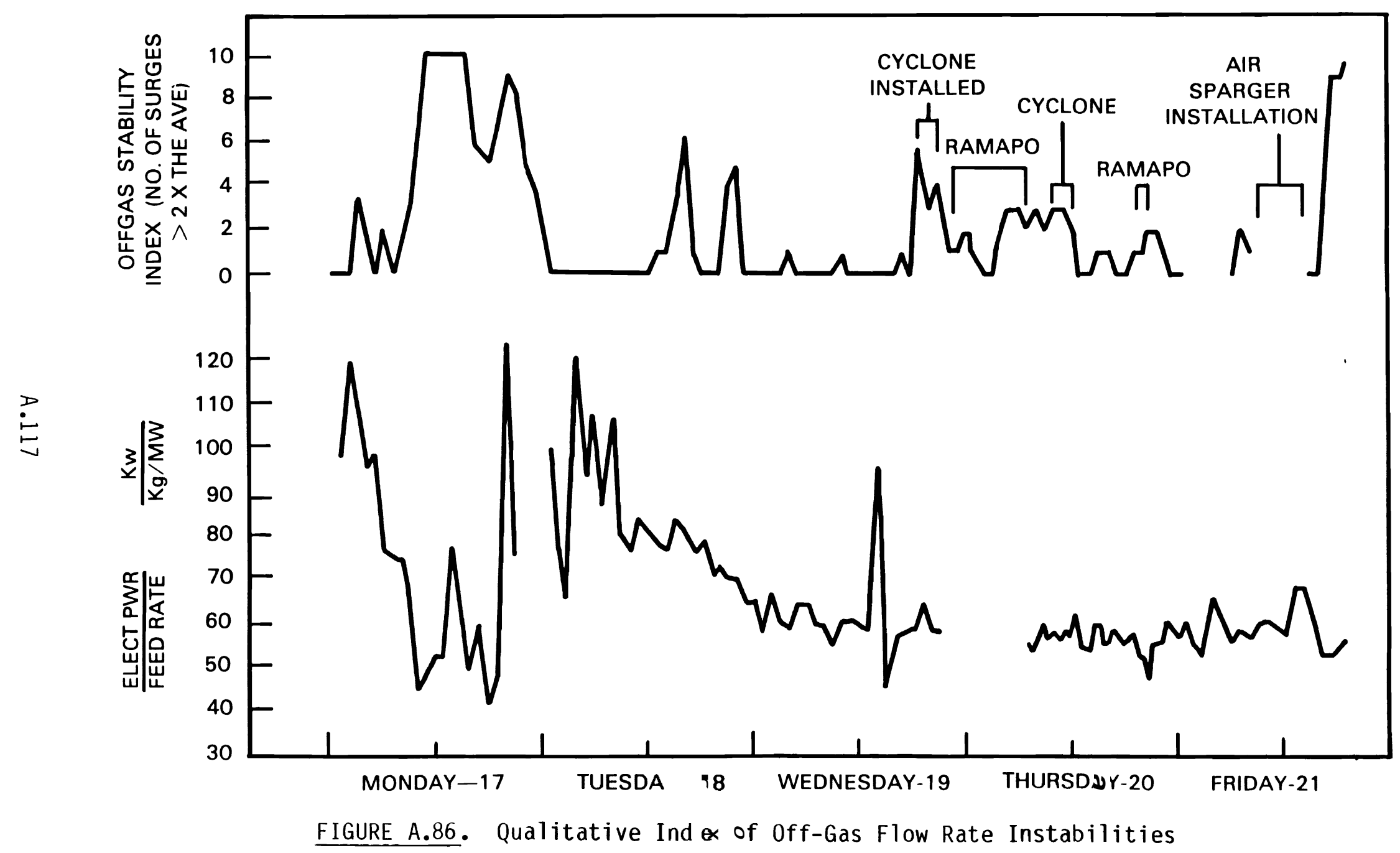


TABLE A.84. PSCM-8 Flow Data

\begin{tabular}{|c|c|c|c|c|c|c|}
\hline Flow, & acfm & & iber A & $\begin{array}{l}\text { f Sur } \\
\text { erage }\end{array}$ & & Average Surge \\
\hline Average & Maximum & 150 & 200 & 250 & 300 & Duration \\
\hline 138 & 391 & 17 & 4 & 4 & 1 & $3 \mathrm{~min}$ \\
\hline
\end{tabular}

noncondensible flow was periodically checked with a pitot tube. The average flow rate of the noncondensible gases was 16 scfm before the HEPA filter sample, $30 \mathrm{scfm}$ when the HEPA filter was valved in, and 22 when the HEPA filter was valved out again. PSCM-8 exhibited much more stable off-gas flow behavior than previous PSCM tests. The average flow rate recorded by the orifice flowmeter was comparable to the calculated value obtained from the noncondensible flow and melter feeding rates. The orifice flowmeter value was $140 \mathrm{acfm}$, and the calculated value was 190 acfm. 


\section{MELTER IDLING TESTS}

Melter emission rates of semivolatile elements were investigated under various idling conditions at the conclusion of PSCM- 5 . Briefly, melter emission rates were determined by direct plenum sampling as a function of plenum temperature and surface glass viscosity. Temperature control was maintained through use of plenum water sprays, which cooled but did not disturb the surface of the melter glass pool. A brief qualitative description of melter characteristics during the test follows.

At a water spraying rate of $43.5 \mathrm{~L} / \mathrm{h}$ and with the melter running under automatic resistance control, the glass surface was cooled to the point that it formed a continuous nonconvective layer above the bulk melter glass pool (plenum $280^{\circ} \mathrm{C}$ ). At $26.5 \mathrm{~L} / \mathrm{h}$, the surface viscosity decreased significantly. Convective mixing opened vents, or fumaroles, in the glass surface that migrated at random across the melter glass pool. However, plenum temperatures were not high enough to melt feed deposits formed upon the melter walls and lid during PSCM-5. Finally, the cooling spray was terminated and the melter was allowed to idle at a fixed current rate, which slowly brought the melter plenum up to $850^{\circ} \mathrm{C}$. Samples were collected from the plenum during all phases of this study.

The results obtained from these plenum samples are summarized in Figure A.87, which characterizes the emission rates of the semivolatile elements under various idling conditions (temperature) employed during this test. These data indicate that emission rates of all semivolatile elements decreased as a function of time after the completion of PSCM-5 under the influence of a $42 \mathrm{~L} / \mathrm{h}$ water spraying rate. Reducing the cooling spray rate to $27 \mathrm{~L} / \mathrm{h}$ measurably increased both plenum temperature and semivolatile emission rates; however, an equilibrated plenum temperature was not achieved during the brief period $(24 \mathrm{~h}$ ) of reduced spraying.

Termination of the water-cooling spray increased the plenum temperature steadily to the point where plenum surface deposits formed during PSCM-5 began to melt and "burn" away. This period was responsible for the dramatic peaking 


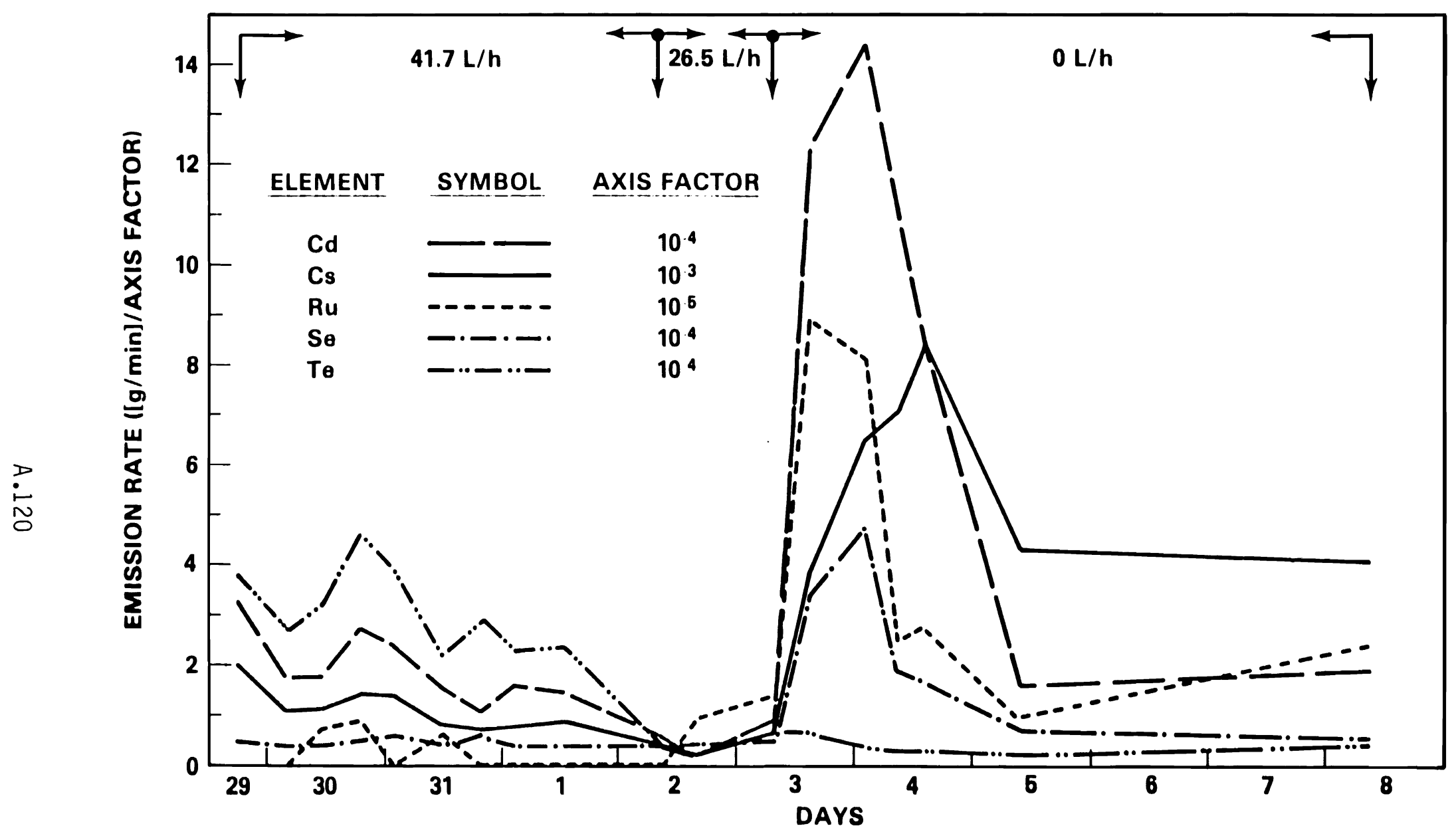

FIGURE A.87. Melter Idling Emission Rates of Semivolatile Elements 
of emission rates of the semivolatile elements. The fact that all semivolatiles do not form maxima at the same point in time is probably due to temperature, which was steadily increasing throughout the interval over'which these maxima occur.

The plenum temperature during the last two sampling periods was $\sim 850^{\circ} \mathrm{C}$, and all plenum surfaces appeared clean. The emission rates during these periods are, with the exception of Se and Te, significantly greater than the minimum emission rates of these elements during full $42 \mathrm{~L} / \mathrm{h}$ spray cooling. However, these elevated idling emission rates are still significantly below those rates observed during moderate liquid feeding conditions. Specifically, the Cs emission rate expected from the PSCM for a liquid feeding rate of $50 \mathrm{~L} / \mathrm{h}$ $(1.1 \mathrm{~kg} / \mathrm{min}$ ) would be $\sim 8 \mathrm{mg} / \mathrm{min}$. This is twice the value observed during hot melter idling conditions. Consequently, it appears that the plenum cooling approach, although capable of reducing emission rates of most semivolatiles (by a factor of 10 for $C s$ ), is of little practical value in reducing the overall melter off-gas radiological burden.

At the conclusion of PSCM-4 the effect of water feeding on the idling melter was investigated. The plenum spray appears to be far superior to direct water feeding as a means of cooling the plenum and melter glass surface. The water feeding technique produced a high degree of entrainment and aerosol carryover into the off-gas system. Moreover, at the water feeding rates used $(45 \mathrm{~L} / \mathrm{h})$, convective mixing was actually exacerbated (total melter flooding was never attempted). On the other hand, the water plenum spray did not initiate entrainment, and minimized or eliminated convective surface mixing. 


\section{CORROSION}

Metal corrosion has been observed in the plenum and off-gas equipment in two liquid-fed melters operated by PNL, the LFCM and the PSCM. The LFCM was constructed with an externally insulated Incone ${ }^{\circledR}$ plenum liner and an Inconel off-gas port, while the PSCM melter has an internally insulated lid. The internal insulation is Alfrax-57. The off-gas port is made of Inconel-690 with a $\mathrm{Cr}_{2} \mathrm{O}_{3}$ plasma-sprayed coating. The only other metal in the PSCM is the Inconel plenum heater thimbles, the feed nozzle and the metal corrosion samples. Both melters use the same stainless steel off-gas system, which consists of a venturi scrubber, a packed tower and a blower. The corrosion of metal parts exposed to the melter off gas will be discussed in the following sections. The operating conditions of the melters during various tests are shown in Table A.85.

$\underline{\text { LFCM }}$

Six experiments were conducted with the LFCM between September 1980 and September 1981 and, duriny that time, a variety of metal parts have corroded. The first component which failed was a stainless steel flex hose installed in the LFCM off-gas line. The hose corroded badly during the first experiment (LFCM-2) after 15 days of idling and 7 days of melter operation. The flex hose was brittle and full of holes near the welded joints. The metal was also flaking badly. Analysis of the corroded metal showed considerable amounts of chloride ( $\mathrm{Cl}$ ) and sulfur (S). The analysis also showed a high chromium ( $\mathrm{Cr}$ ) concentration in relation to the iron ( $\mathrm{Fe}$ ) and nickel ( $\mathrm{Ni}$ ) present in stainless steel. The corroded pieces were magnetic, indicating that the $\mathrm{Ni}$ was being attacked by $\mathrm{S}$ and $\mathrm{Cl}$, which is typical of sulfidation attack. (Sulfidation causes high $\mathrm{Cr}-\mathrm{Fe}$ alloys to become magnetic like the flex hose.)

It was also noted that the deposits downstream of the flex hose had high concentrations of $\mathrm{Fe}$ and $\mathrm{Ni}$ relative to their concentrations in the glass. Analysis of the plug material is shown in Table A.86. Because $\mathrm{Fe}$ and $\mathrm{Ni}$ are not considered volatile, the extra $\mathrm{Fe}$ and $\mathrm{Ni}$ probably came from the flex hose 
TABLE A.85. Melter Operation Summary

\begin{tabular}{|c|c|c|c|c|c|c|c|c|c|c|c|c|}
\hline & & & FCM & & & & & & SCM & & & \\
\hline Run No. & 2 & 3 & 4 & 5 & 6 & 7 & 3 & 4 & 5 & 6 & 7 & 8 \\
\hline $\begin{array}{l}\text { Operating plenum } \\
\text { temperatore, }{ }^{\circ} \mathrm{C}\end{array}$ & $400-800$ & 350 & 600 & -- & 600 & 500 & 250 & 350 & 550 & 700 & 300 & 800 \\
\hline $\begin{array}{l}\text { Idlinz glenum } \\
\text { temperafure, }{ }^{\circ} \mathrm{C}\end{array}$ & $\sim 900$ & $\sim 900$ & $\sim 900$ & $\sim 900$ & $\sim 900$ & $\sim 900$ & $\sim 900$ & $\sim 900$ & $\sim 900$ & $\sim 900$ & $\sim 900$ & $\sim 900$ \\
\hline $\begin{array}{l}\text { Off-gas operating } \\
\text { temperature, }{ }^{\circ} \mathrm{C}\end{array}$ & $300-600$ & 325 & 325 & -- & 300 & 250 & 350 & 300 & 400 & 400 & 275 & 400 \\
\hline $\begin{array}{l}\text { Days idling } \\
\text { before run }\end{array}$ & 15 & 38 & 73 & 30 & 97 & 79 & 116 & $30(a)$ & 42 & 49 & 53 & 27 \\
\hline Days of operation & 9 & 1 & 5 & 1 & 5 & 5 & 5 & 5 & 5 & 6 & 5 & 10 \\
\hline $\begin{array}{l}\text { Plenum boosting } \\
\text { power, kW }\end{array}$ & 25 & 0 & 30 & 6 & 45 & 17 & 0 & 0 & 36 & 55 & 0 & 45 \\
\hline
\end{tabular}

(a) New lid. 
TABLE A.86. Composition of Material From Off-Gas Plug

\begin{tabular}{|c|c|c|c|}
\hline $\begin{array}{c}\text { Elemental } \\
\text { Oxides }\end{array}$ & $\begin{array}{l}\text { Average } \\
\text { Wt\% i n } \\
\text { Plug } \\
\end{array}$ & $\begin{array}{r}\text { Wt } \% \text { Feed } \\
9 / 18 / 72 \\
\text { at } 2030 \mathrm{~h} \\
\end{array}$ & $\begin{array}{l}\text { Ratio of } \\
W t \% \text { Plug/ } \\
W t \% \text { Feed }\end{array}$ \\
\hline $\mathrm{Al}_{2} \mathrm{O}_{3}$ & 1.67 & 2.96 & 0.56 \\
\hline $\mathrm{B}_{2} \mathrm{O}_{3}$ & 4.62 & 3.78 & 1.22 \\
\hline $\mathrm{CaO}$ & 4.40 & 4.62 & 0.95 \\
\hline $\mathrm{Cs}_{2} \mathrm{O}$ & 0.26 & 0.04 & 3.0 \\
\hline $\mathrm{Fe}_{2} \mathrm{O}_{3}$ & 20.3 & 10.9 & 1.86 \\
\hline $\mathrm{Li}_{2} \mathrm{O}$ & 2.02 & 2.42 & 0.83 \\
\hline $\mathrm{MgO}$ & 0.22 & 0.11 & 2.00 \\
\hline $\mathrm{MnO}_{2}$ & 1.21 & 3.67 & 0.32 \\
\hline $\mathrm{Na}_{2} \mathrm{O}$ & 16.9 & 13.0 & 1.30 \\
\hline $\mathrm{NiO}$ & 2.49 & 1.32 & 1.89 \\
\hline $\mathrm{RuO}_{2}$ & 0.30 & 0.01 & 30.0 \\
\hline $\mathrm{SiO}_{2}$ & 31.0 & 35.0 & 0.89 \\
\hline sro & 0.04 & 0.02 & 2.0 \\
\hline $\mathrm{TeO}_{2}$ & 0.07 & 0.004 & 17.5 \\
\hline $\mathrm{TiO}_{2}$ & 0.07 & 0.03 & 2.33 \\
\hline Zno & 0.08 & 0.04 & 2.0 \\
\hline
\end{tabular}

corrosion products. The flex hose corrosion was also caused by hightemperature cycling and flex hose stresses that were induced when tilting the melter. The plenum temperature during this period varied between 400 and $800^{\circ} \mathrm{C}$.

Since LFCM-2, the off-yas temperature has been kept below $400^{\circ} \mathrm{C}$ by using a water-cooliny spray during operation. During idling, the off-gas flow was decreased, so the off-gas temperature is relatively low a few feet from the melter, and the new flex hose has not corroded significantly.

About seven months after the flex hose corroded, signs of liner failure occurred. Some metal strips (Inconel-601) on the underside of the melter lid were observed to be hanging down from the melter lid. 
After the lid failure was observed, a temperature excursion occurred, raising the glass temperatures above $1400^{\circ} \mathrm{C}$. After the temperature excursion, the melter lid was inspected with a metallic mirror, and about 50\% of the lid's metal underside was missing, as shown in Figure A.88.

The Inconel-601 walls were relatively undamaged. The difference in damage between the walls and lid could be caused by the different stresses in the lid, or the different temperatures encountered. The walls form the protective shield for the plenum heaters, which keeps the walls above $900^{\circ} \mathrm{C}$ during operation, while the lid temperature cycles between 400 and $1000^{\circ} \mathrm{C}$.

After the next LFCM run, the badly-corroded off-gas port (Sch. 40 Inconel-601 pipe) broke away from the lid while the off-gas lines were being disassembled for inspection. Unlike Inconel, the port possessed magnetic properties. Analysis by x-ray diffraction showed layers of $\mathrm{NiCrO}_{4}, \mathrm{NiFe}_{2} \mathrm{O}_{4}$ spinels, and metallic $\mathrm{Ni}$. The analysis by SEM revealed large amounts of $\mathrm{Cl}$ and $\mathrm{S}$ in the void spaces, which indicates there was $\mathrm{Cl}$ and $\mathrm{S}$ attack.

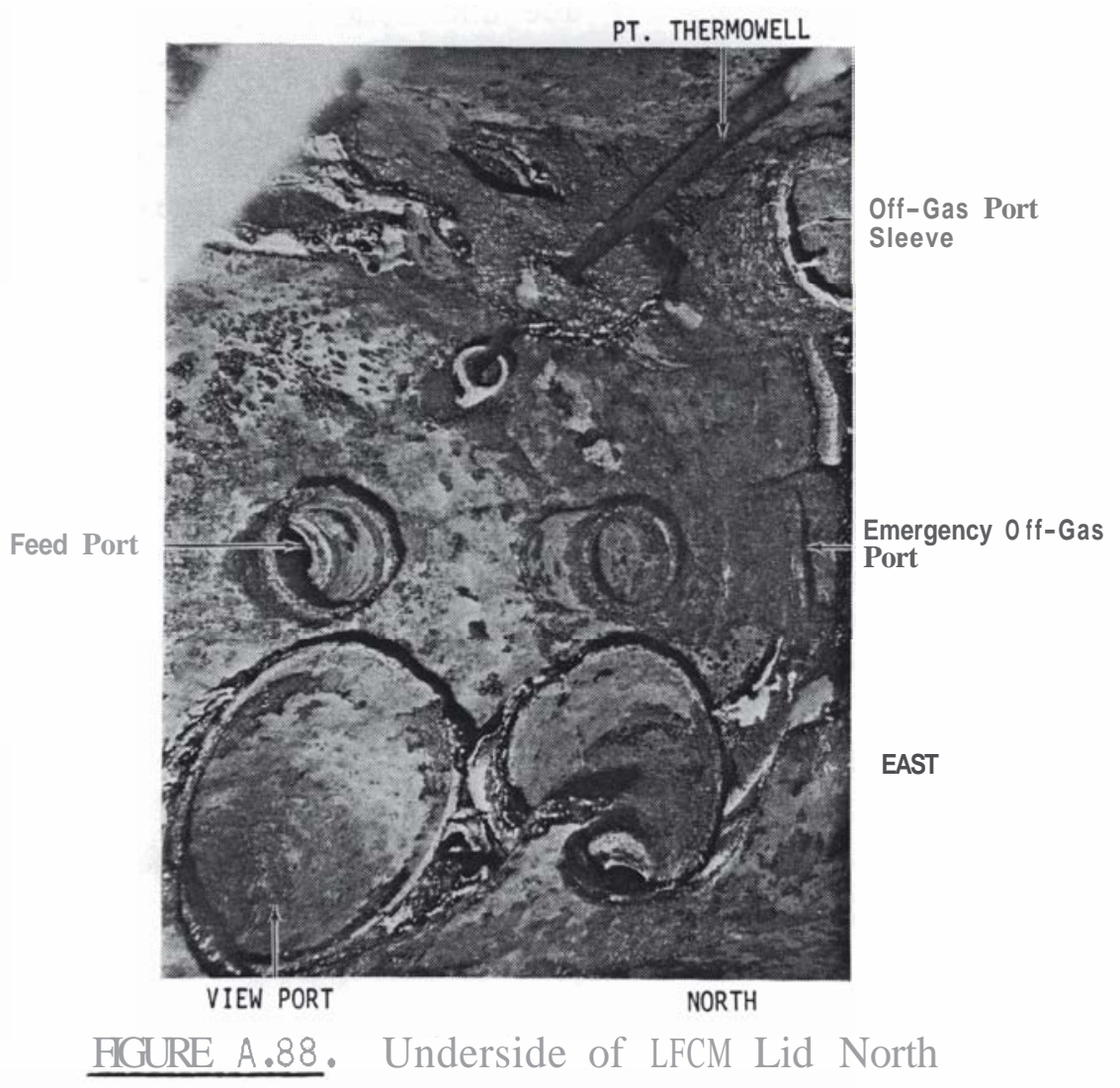


Analysis of off-gas line deposits formed during idling periods have shown $\mathrm{NaCl}$ concentrations ranging from 20 to $90 \%$ and $\mathrm{S}$ concentrations as high as $30 \%$. These analyses indicate sulfidation attack, but do not rule out the possibility that the high temperature excursion contributed to the port's premature failure.

After the incidents mentioned above, the off-gas port was replaced and corrosion samples were mounted in the LFCM plenum. The corrosion resistance of the metal samples are shown in Table A.87. Visual observations indicate that Inconel- 690 and -625 are the best alloys of the group.

The ability of the coatings to survive the plenum atmosphere is largely due to surface preparation, coating selection and a precisely controlled application technique. The oxide coating used and the application combination are shown in Tables A.88 and A.89.

All the oxide-coated samples spalled severely except for $\mathrm{Cr}_{2} \mathrm{O}_{3}$, where only a little coating was lost. The $\mathrm{Ni}-\mathrm{Cr}$ base coat alone did not spall, but there was some attack at the coating surface and some physical changes at the coating substrate interface which have not been defined at this point. Spalling and coating changes can be seen in Figures A.89 through A.94. A possible explanation for the spalling is that the small coupons were heated too high during the deposition step, severely cornpressiny the ceramic layer upon cooling. The

TABLE A.87. Metal1ic Corrosion Sample Results

$\begin{array}{lll}\frac{\text { Material }}{\text { Tantalum }} & & \text { No longer on sample rack; disappeared } \\ \text { Titanium }(a) & & \text { Large flakes, deep pits; badly corroded } \\ \text { Inconel-690 } & & \text { Discolored spots } \\ \text { Inconel-625 } & & \text { Discolored spots } \\ \text { Inconel-617 } & & \text { Discolored, green spots; obvious metal loss } \\ \text { Inconel-600 } & \text { Many discolored spots } \\ 304 \text { SS } & \text { Lots of flaking metal; oxidizing rapidly }\end{array}$

(a) Only one sample. Other materials had two samples each. 
TABLE A.88. Protective Coating Off-Gas Samples

\begin{tabular}{|c|c|c|c|c|c|c|}
\hline \multirow[b]{2}{*}{ Sample No. } & \multicolumn{2}{|c|}{ Bond Coating } & \multicolumn{2}{|c|}{ Outer Coating } & \multirow[b]{2}{*}{$\frac{\text { Surface }}{\text { Cleaned }}$} & \multirow[b]{2}{*}{$\begin{array}{l}\text { Preparation } \\
\text { Blasted }\end{array}$} \\
\hline & METCOID & $\begin{array}{c}\text { Thickness, } \\
\mu \mathrm{m}\end{array}$ & METCOID & $\begin{array}{c}\text { Thickness, } \\
\mu \mathrm{m}\end{array}$ & & \\
\hline 1 & -- & -- & -- & -- & $x$ & \\
\hline 2 & -- & -- & -- & -- & & $x$ \\
\hline 3 & $43 F-N S$ & 380 & -- & -- & $x$ & \\
\hline 4 & $43 F-N S$ & 380 & -- & -- & & $x$ \\
\hline 5 & $43 C$ & 250 & -- & -- & $x$ & \\
\hline 6 & $43 C$ & 250 & -- & -- & & $x$ \\
\hline 7 & 443 & 250 & -- & -- & $x$ & \\
\hline 8 & 443 & 250 & -- & -- & & $x$ \\
\hline 9 & 443 & 250 & $105 \mathrm{SF}$ & 250 & & $x$ \\
\hline 10 & 443 & 250 & 105 & 250 & & $x$ \\
\hline 11 & 443 & 250 & 106 & 250 & & $x$ \\
\hline 12 & 443 & 250 & 202NS & 250 & & $x$ \\
\hline 13 & 443 & 250 & 201 & 250 & & $x$ \\
\hline 14 & 443 & 250 & 201B-NS-1 & 250 & & $x$ \\
\hline
\end{tabular}

already weakened coating then spalled of $f$ when cycled back up to the plenum temperature. The pictures are grouped in pairs; the one marked CONTROL is an unexposed sample with the same type of coating as the plenum sample portrayed in the adjacent picture. The light shaded areas are the metal substrates and the areas with mixed shading are the coatings. Figures A.89 and A.90 are photos of the $\mathrm{Ni}-\mathrm{Cr}$ base coat, which shows very little corrosion, but it does show the base coat substrate interaction. Figures A.91 and A.92 are photos of the $\mathrm{Ni}-\mathrm{Cr}-6 \% \mathrm{Al}$ base coat with a $\mathrm{Cr}_{2} \mathrm{O}_{3}$ secondary coat, showing some cracking of the oxide coat and the same base coat-substrate interaction shown in Figures A.89 and A.90. Figures A.93 and A.94 are photos taken of the ZrO-coated sample with a $\mathrm{Ni}-\mathrm{Cr}$ base coat. A great deal of cracking and material loss of the ceramic layer are evident. These pictures are typical of the other coated samples. These results suggest that more work is needed to develop and refine coating techniques. 
TABLE A.89. Spray Powder Characteristics

\begin{tabular}{|c|c|c|c|c|c|}
\hline Spray Powder & Powder ID & Constituent & Percent & Ranye, $\mu \mathrm{m}$ & Comments \\
\hline Nickel-Chromium Alloy & 43F-NS & $\begin{array}{l}\mathrm{Ni} \\
\mathrm{Cr}\end{array}$ & $\begin{array}{l}80 \\
20\end{array}$ & $-53+10$ & $\begin{array}{l}\text { Best single coating for oxidation } \\
\text { resistance to } 980^{\circ} \mathrm{C} \text {. }\end{array}$ \\
\hline Nickel-Chromium Alloy & $43 \mathrm{C}$ & $\begin{array}{l}\mathrm{Ni} \\
\mathrm{Cr}\end{array}$ & $\begin{array}{l}80 \\
20\end{array}$ & $-105+10$ & Good bond coat $+\mathrm{O}_{2}$ barrier to $980^{\circ} \mathrm{C}$. \\
\hline $\begin{array}{l}\text { Nickel-Chromium/ } \\
\text { Aluminum Composit e }\end{array}$ & 443 & $\stackrel{\mathrm{Al}}{\mathrm{Ni}-\mathrm{Cr}}$ & $\begin{array}{l}60 \\
\text { Bal ance }\end{array}$ & $-120+45$ & Best bond coat $+\mathrm{O}_{2}$ barrier to $980{ }^{\circ} \mathrm{C}$. \\
\hline Ceramic & $105 S F$ & $\begin{array}{l}\qquad \mathrm{Al}_{2} \mathrm{O}_{3} \\
\mathrm{SiO}_{2} \\
\text { Other Oxides }\end{array}$ & $\begin{array}{l}98.5 \\
0.5 \\
1.5\end{array}$ & $-25+05$ & Wear resistant. \\
\hline White Alumina & 105 & $A 12^{O_{3}}$ & 98.5 & $-53+15$ & Resists erosion from 840 to $1650^{\circ} \mathrm{C}$. \\
\hline & & $\begin{array}{l}\mathrm{SiO}_{2} \\
\text { Other Oxides }\end{array}$ & $\begin{array}{c}1.0 \\
\text { Balance }\end{array}$ & & Wear resistant. \\
\hline Chromium Oxide & 106 & $\mathrm{Cr}_{2} \mathrm{O}_{3}$ & 98 & $-90+15$ & $\begin{array}{l}\text { Resists abrasion, cavitation \& erosion } \\
\text { to } 540^{\circ} \mathrm{C} \text {. Insoluble in acids, alkalis } \\
\text { and alcohol. }\end{array}$ \\
\hline $\begin{array}{l}\text { Zirconium Oxide } \\
\text { Composite }\end{array}$ & $202 N S$ & $\begin{array}{l}\mathrm{ZrO}_{2} \\
\mathrm{Y}_{2} \mathrm{O}_{3}\end{array}$ & $\begin{array}{l}80 \\
20\end{array}$ & $-90+10$ & $\begin{array}{l}\text { Resists thermal shock and particle } \\
\text { erosion to } 1650^{\circ} \mathrm{C} \text {. }\end{array}$ \\
\hline Zirconium Oxide & 201 & $\begin{array}{c}\mathrm{ZrO}_{2} \\
\mathrm{CaO} \\
\mathrm{Al}_{2} \mathrm{O}_{3} \\
\text { Other Oxides }\end{array}$ & $\begin{array}{c}80 \\
5 \\
0.5 \\
\text { Balance }\end{array}$ & $-90+10$ & $\begin{array}{l}\text { Resists thermal shock and particle } \\
\text { erosion above } 845^{\circ} \mathrm{C} \text {. }\end{array}$ \\
\hline $\begin{array}{l}\text { Zirconium Oxide } \\
\text { Composite }\end{array}$ & $201 B-N S-1$ & $\begin{array}{l}\mathrm{ZrO}_{2} \\
\mathrm{CaCO}_{3}\end{array}$ & $\begin{array}{l}92 \\
8\end{array}$ & & $\begin{array}{l}\text { Resists thermal shock and particle } \\
\text { erosion above } 845^{\circ} \mathrm{C} \text {. }\end{array}$ \\
\hline
\end{tabular}




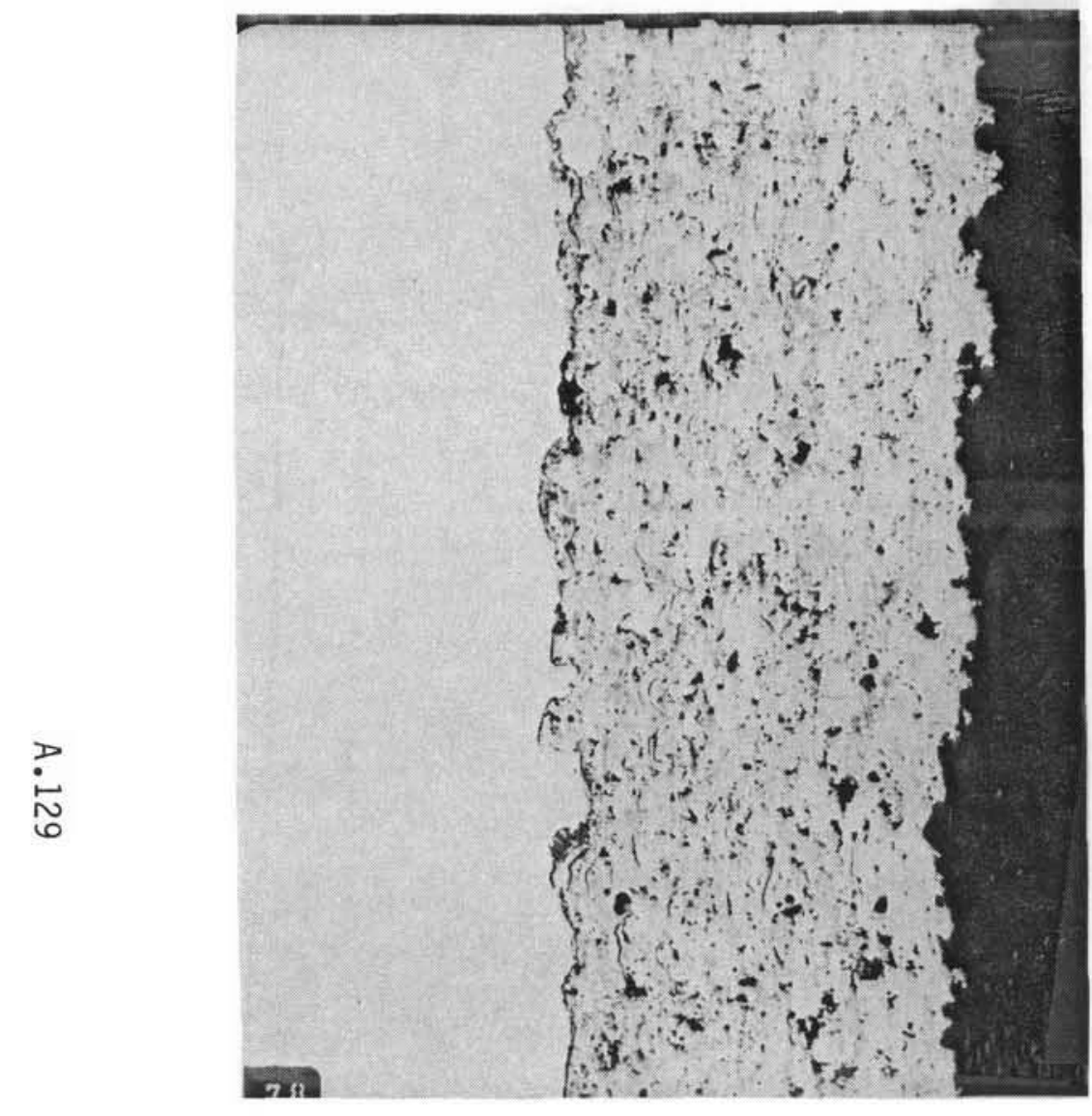

\#4 Control

$100 x$

FIGURE A.89. SEM Photograph of $\mathrm{Ni}-\mathrm{Cr}$ Base Coat Under 100X Magnification - Control

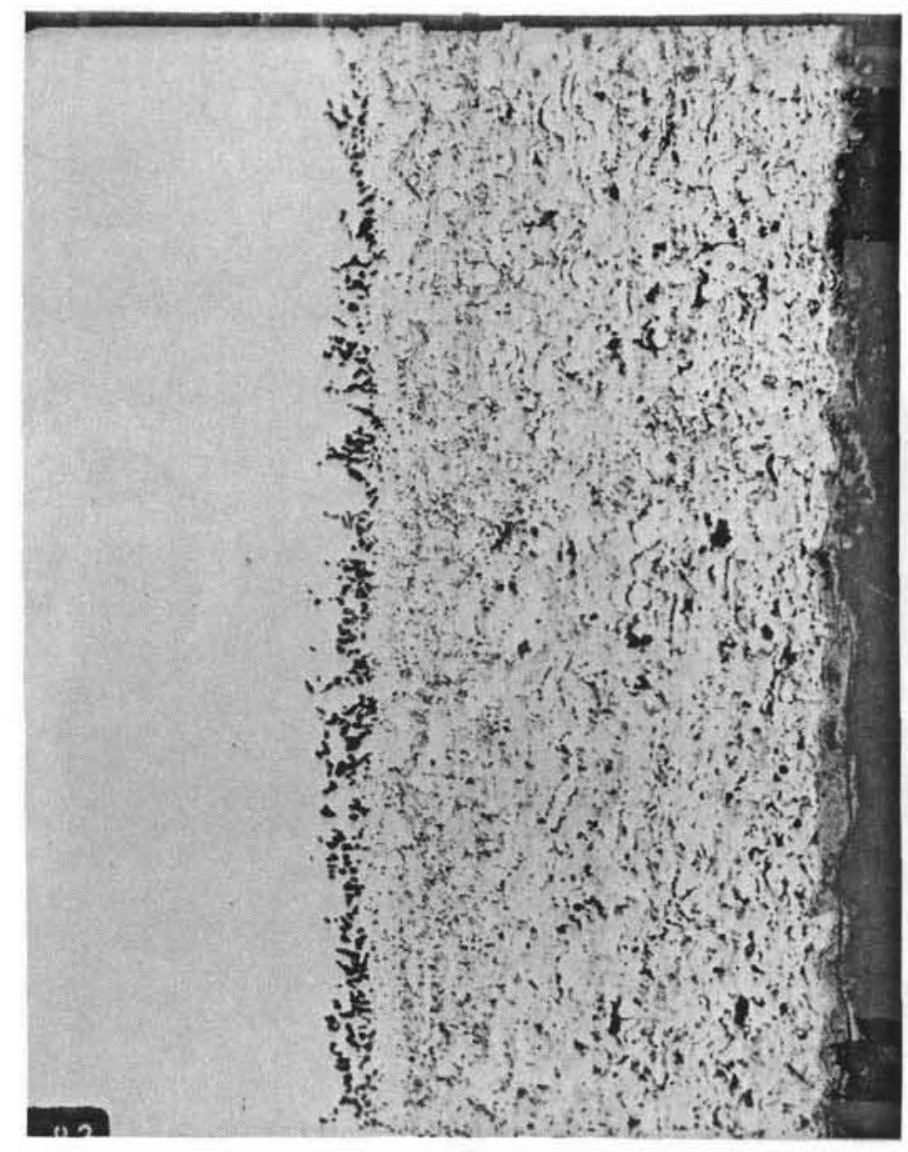

\#4

$100 x$

FIGURE A.90, SEM Photograph of $\mathrm{Ni}-\mathrm{Cr}$ Base Coat Showing Very Little Corrosion Under 100X Magnification 


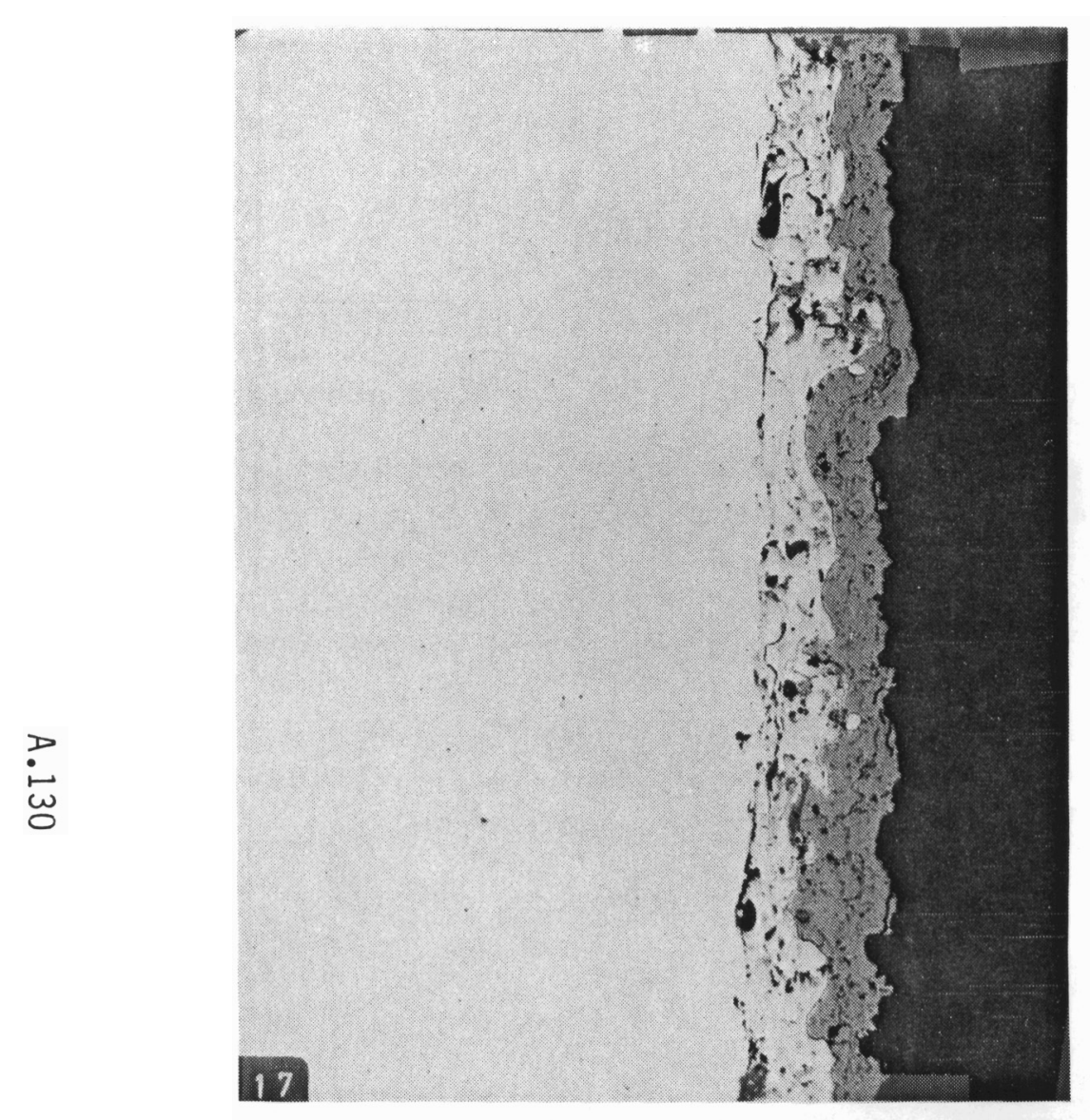

\#11 Control

$100 x$

FIGURE A.91. SEM thotograph of $\mathrm{Ni}-\mathrm{Cr}-6 \%$ Base Coat wi.hn a $\mathrm{Cr}_{2} \mathrm{O}_{3}$ Secondary coat Under 100x Magnification - Control

\section{2}

\#11

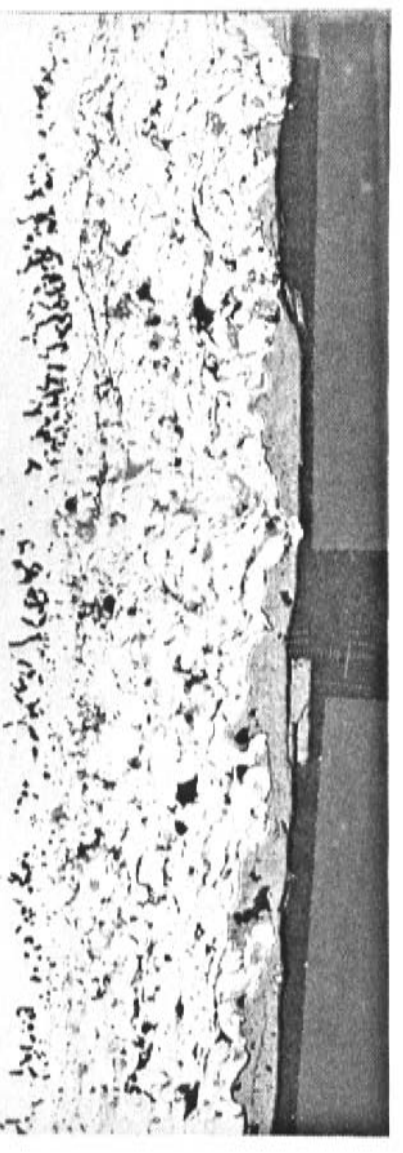

$100 x$

FIGURE A.92. SEM Whotograph of $\mathrm{Ni}-\mathrm{Cr}-6 \%$ Base Coat with a $\mathrm{Cr}_{2} \mathrm{O}_{3}$ Secondary coat and Some Crackinz Un $<e r$ 100X Magnification 


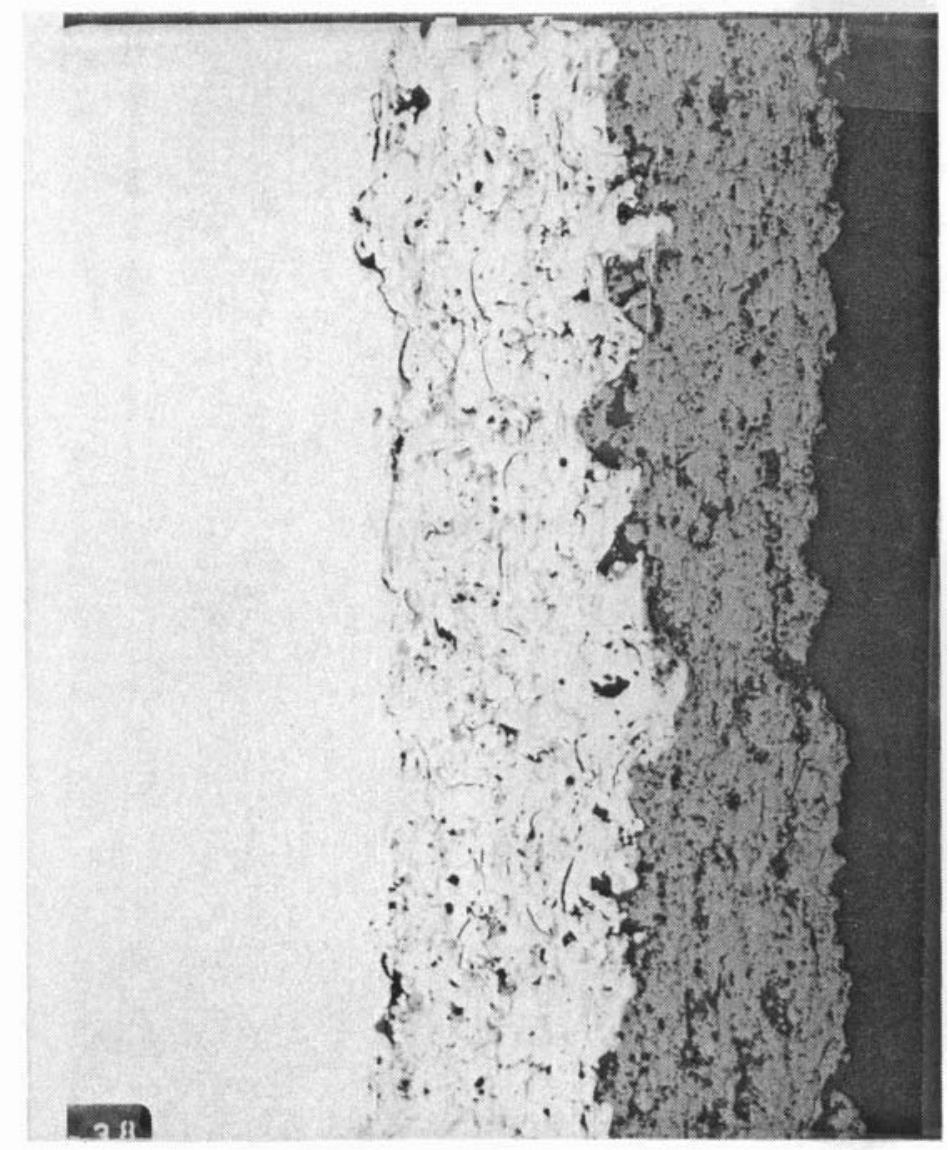

\#12 Control

$100 x$

FIGURE A.93. SEM Photograph of ZrO-Coated

Sample with a $\mathrm{Ni}-\mathrm{Cr}$ Base

Coat Under 100X Magnification Control

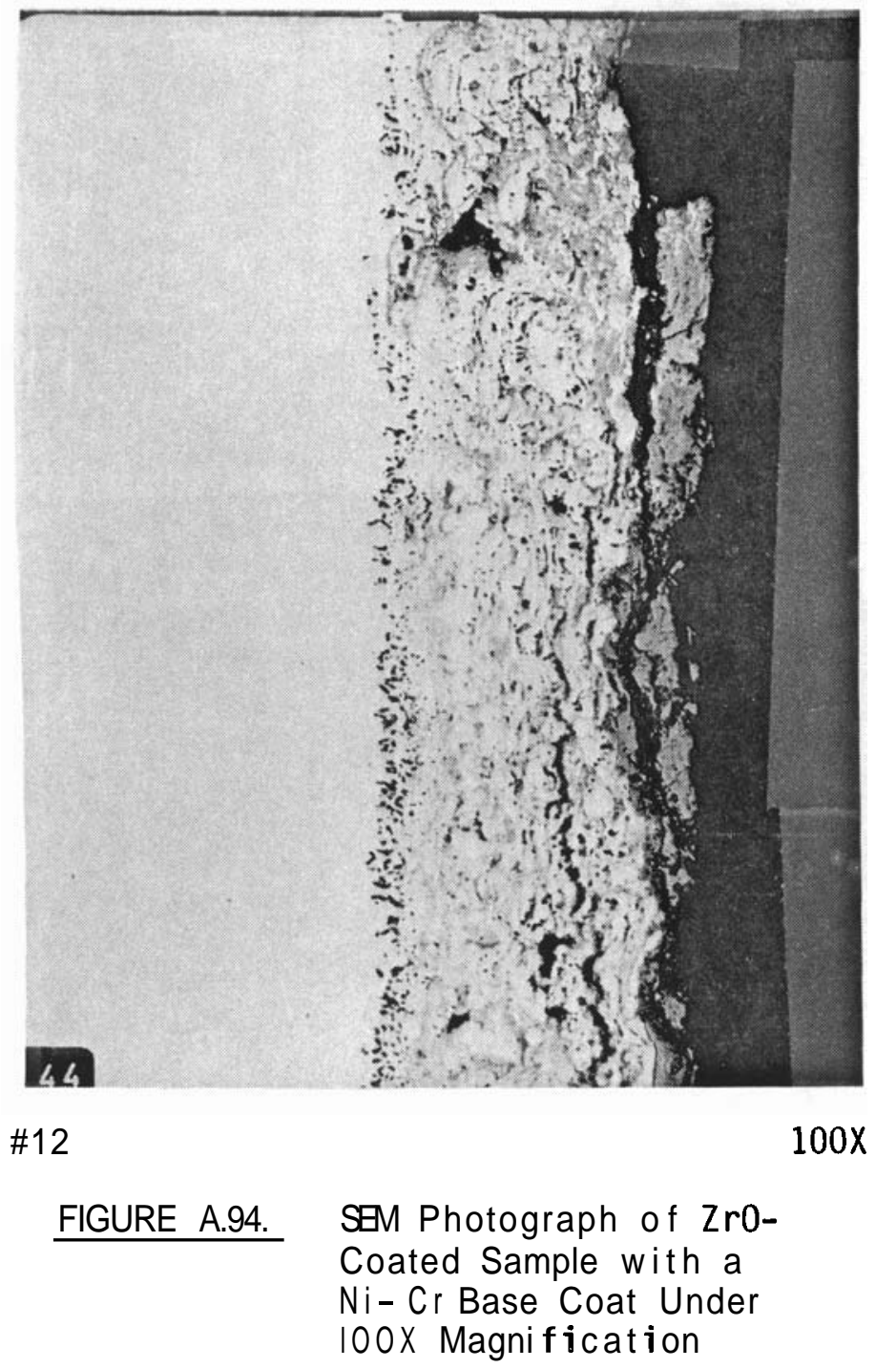


The most promising coupon samples from the LFCM tests were combined with additional metal samples for testing in the PSCM plenum after the LFCM tests were discontinued. The corrosion samples were chosen to represent different groups of alloys, and the exposure time was varied so the separate effects of idling and melter operation could be determined. The physical appearance and weight of the metal samples were recorded before and after exposure, and the results are shown in Table A.90. Some samples had tenacious particle deposits, so the corrosion rates shown may be low. The deposits also make sample comparison difficult, but the adherence of the deposit may indicate that the surface of the samples is in good condition; the samples with heavy spalling had no deposits.

Examination of the metal samples indicates that idling is not the major contributor to metal corrosion, since duplicate alloys exposed to lengthy idling periods have lower corrosion rates than samples primarily exposed to operating conditions. The cycling between idling and operation could be a cause of corrosion since all the coupons were subjected to cycling. The results also indicate that titanium, tantalum and alloys with high iron concentrations are very susceptible to corrosion.

The alloys' corrosion rate appears to be directly related to the iron concentration, as is clearly shown by comparing corrosion results obtained from RA-446, RA-330, Inconel-615 and the Haynes alloys (see Table A.90). The most promising alloys appear to have low iron, high nickel or cobalt, and 20 to $25 \%$ chromium. The cobalt-based alloys are yenerally considered more corrosion resistant to sulfidation corrosion and should be considered in place of nickelbased alloys.

SEM micrographs were obtained of the cross-sections of the best alloys, which include Inconel-690 and -625, Haynes 188 and 25, and Hastelloy $X$. (see Figures A.95 through A.103). Figure A.95 is an unexposed Inconel-625 sample for comparison. A summary of the samples' conditions and exposures is given in Table A.91. Overall, the micrographs show $\mathrm{Cr}$ migration to the surface of the alloys and voids underneath the $\mathrm{Cr}_{2} \mathrm{O}_{3}$ layer. The samples all appear depleted in $\mathrm{Ni}$ or $\mathrm{Co}$, with segregation of the $\mathrm{Ni}$ and $\mathrm{Cr}$. Most of the micrographs show $\mathrm{CrS}$ underneath the $\mathrm{Cr}_{2} \mathrm{O}_{3}$ layer typical of sulfidation or hot corrosion. A more detailed description of the coupon samples examined is given below. 
TABLE A.90. Corrosion Data

\begin{tabular}{|c|c|c|c|c|c|c|c|c|c|c|c|c|}
\hline \multirow[b]{2}{*}{ Material } & \multicolumn{2}{|c|}{$\begin{array}{l}\text { Corrosion } \\
\text { Exposure, } h\end{array}$} & \multirow{2}{*}{$\begin{array}{l}\text { Rate, } \\
\mathrm{mm} / \mathrm{yr}\end{array}$} & \multicolumn{2}{|c|}{ Observations } & \multicolumn{7}{|c|}{ Approximate Composition, wt\% } \\
\hline & Idinp & 0peratin $p$ & & Pitting & Spalling & Deposits & Co & $\mathrm{Cr}$ & $\mathrm{Fe}$ & $\mathrm{Mb}$ & $\mathrm{Ni}$ & W \\
\hline Inconel ${ }^{\otimes}-690$ & $\begin{array}{r}1340 \\
1270 \\
340 \\
460 \\
\end{array}$ & $\begin{array}{l}700 \\
584 \\
584 \\
700 \\
\end{array}$ & $\begin{array}{r}\star 0.23 \\
0.26 \\
0.43 \\
0.17 \\
\end{array}$ & $\begin{array}{l}\mathrm{N} \\
\mathrm{N} \\
\mathrm{N} \\
\mathrm{N}\end{array}$ & $\begin{array}{l}M \\
M \\
L \\
M\end{array}$ & $\begin{array}{l}\mathrm{N} \\
\mathrm{N} \\
\mathrm{N} \\
\mathrm{N}\end{array}$ & -- & 30 & 9.5 & -- & 60 & -- \\
\hline Inconelm-625 & $\begin{array}{r}460 \\
1270 \\
340 \\
1390 \\
\end{array}$ & $\begin{array}{l}700 \\
584 \\
584 \\
700 \\
\end{array}$ & $\begin{array}{c}\star 0.03 \\
0.03 \\
\mathbf{t} \\
{ }^{*} 0.01\end{array}$ & $\begin{array}{c}\mathrm{N} \\
\mathrm{N} \\
\mathrm{N} \\
\text { Small Pits }\end{array}$ & $\begin{array}{l}-- \\
-- \\
-- \\
--\end{array}$ & $\begin{array}{l}\mathrm{H} \\
\mathrm{L} \\
\mathrm{L} \\
\mathrm{M}\end{array}$ & -- & 21.5 & 2.5 & 9 & 61 & -- \\
\hline Haynes -188 & $\begin{array}{r}1270 \\
340 \\
100 \\
\end{array}$ & $\begin{array}{l}584 \\
584 \\
232 \\
\end{array}$ & $\begin{array}{c}\star 0.07 \\
0.05 \\
\star 3.6 \\
\end{array}$ & $\stackrel{N}{N}$ & $\begin{array}{c}\mathrm{M} \\
\text { Pitted }\end{array}$ & $\begin{array}{l}\mathrm{H} \\
\mathrm{M} \\
\mathrm{N} \\
\end{array}$ & 49 & 22 & $<3$ & -- & 22 & 15 \\
\hline Haynes ${ }^{\circ}-25$ & $\begin{array}{r}1270 \\
160 \\
340 \\
100 \\
\end{array}$ & $\begin{array}{l}584 \\
480 \\
584 \\
232 \\
\end{array}$ & $\begin{array}{c}\mathbf{t} \\
0.55 \\
\star 0.04 \\
9.6 \\
\end{array}$ & $\begin{array}{c}\mathrm{N} \\
\mathrm{N} \\
\mathrm{N} \\
\text { One Wide Pit } \\
\end{array}$ & $\begin{array}{c}\mathrm{H} \\
\mathrm{M} \\
\mathrm{M} \\
\text { Pitted } \\
\end{array}$ & $\begin{array}{l}\mathrm{L} \\
\mathrm{L} \\
\mathrm{L} \\
\mathrm{L}\end{array}$ & 54 & 21 & $<3$ & -- & 10 & 15 \\
\hline$H A "-330$ & $\begin{array}{r}1270 \\
340 \\
\end{array}$ & $\begin{array}{l}584 \\
584 \\
\end{array}$ & $\begin{array}{l}0.38 \\
0.62 \\
\end{array}$ & $\begin{array}{l}\mathrm{N} \\
\mathrm{N}\end{array}$ & $\begin{array}{l}\mathrm{H} \\
\mathrm{M}\end{array}$ & $\begin{array}{l}\mathrm{N} \\
\mathrm{N}\end{array}$ & -- & 18 & 47 & - & 35 & -- \\
\hline$R A^{\infty}-446$ & $\begin{array}{r}1170 \\
238 \\
\end{array}$ & $\begin{array}{l}352 \\
352 \\
\end{array}$ & $\begin{array}{l}1.9 \\
3.7\end{array}$ & $\begin{array}{l}\mathrm{N} \\
\mathrm{N}\end{array}$ & $\begin{array}{l}\mathrm{H} \\
\mathrm{H} \\
\end{array}$ & $\begin{array}{l}\mathrm{N} \\
\mathrm{N}\end{array}$ & -- & 25 & 75 & - & -- & -- \\
\hline Hastelloy $X$ & 100 & 232 & ${ }^{\star} 0.94$ & One $1 "$ dia pit & Pitted & $\mathrm{L}$ & 1.5 & 23 & 18.5 & 9 & 47 & 0.6 \\
\hline Hastelloy C-4 & 100 & 232 & $>48$ & Disappeared & -- & $\mathrm{N}$ & -- & 16 & 3 & 15 & 65 & -- \\
\hline Hastelloy S & 40 & 138 & 40 & Badly Pitted & $\mathrm{L}$ & $\mathrm{N}$ & -- & 16 & 3 & 15 & 65 & -- \\
\hline Inconel-600 & 222 & 348 & 0.23 & $\mathrm{~N}$ & $\mathrm{M}$ & $\mathrm{L}$ & - & 15.5 & 8 & -- & 76 & -- \\
\hline Inconel-617 & 122 & 116 & 0.16 & Pitted & $\ldots$ & M & 12 & 22 & 1.5 & 9 & 52 & -- \\
\hline Tantalum & 122 & 116 & 30 & Disappeared & -- & - & -- & -- & -- & -- & -- & -- \\
\hline Titanium & 122 & 116 & 2.1 & Pitted Badly & $\mathrm{H}$ & $\mathrm{N}$ & -- & -- & -- & -- & -- & -- \\
\hline
\end{tabular}

* Samples were not washed before obtaining final weight.

- Inconel is a registered trademark of Huntington Alloys.

- Haynes is a registered trademark of the Cabot Corporation, Kokomo, Indiana.

- $\mathrm{RA}$ is a registered trademark of Rolled Alloys, Detroit, Michigan.

$\mathrm{H}$ Heavy

$M$ Medium

L Light

$\mathrm{N}$ None 


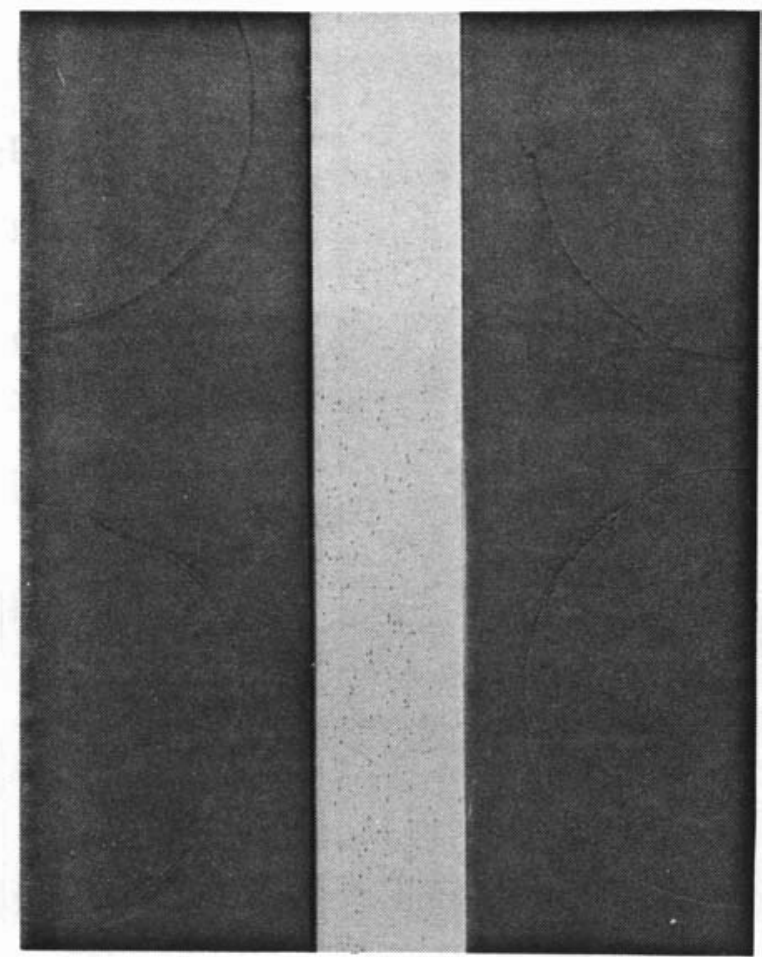

$10 x$
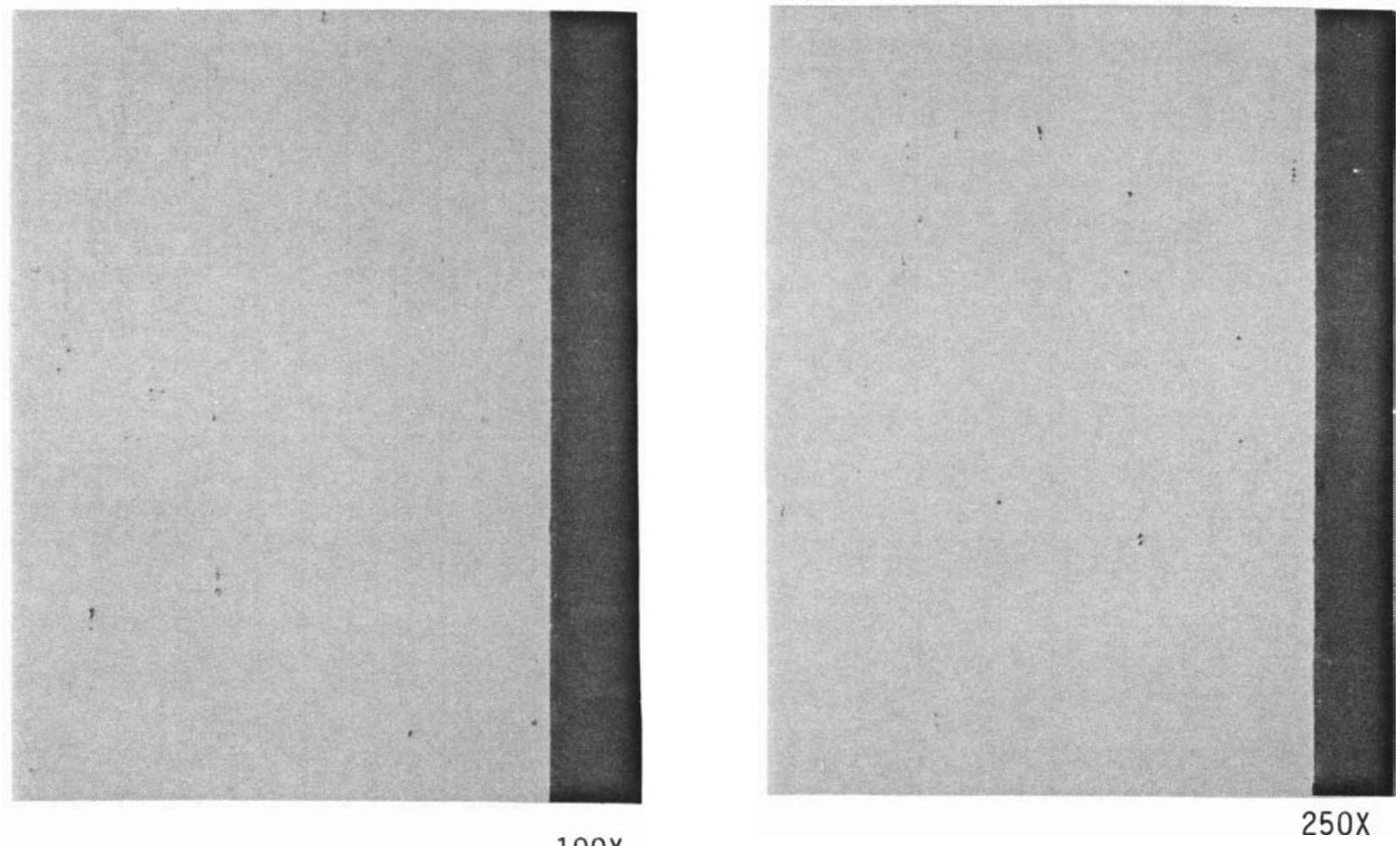

FIGURE A.95. Inconel-625 Unexposed Sample Under 10X, 100X and 250X SEM Magnification 


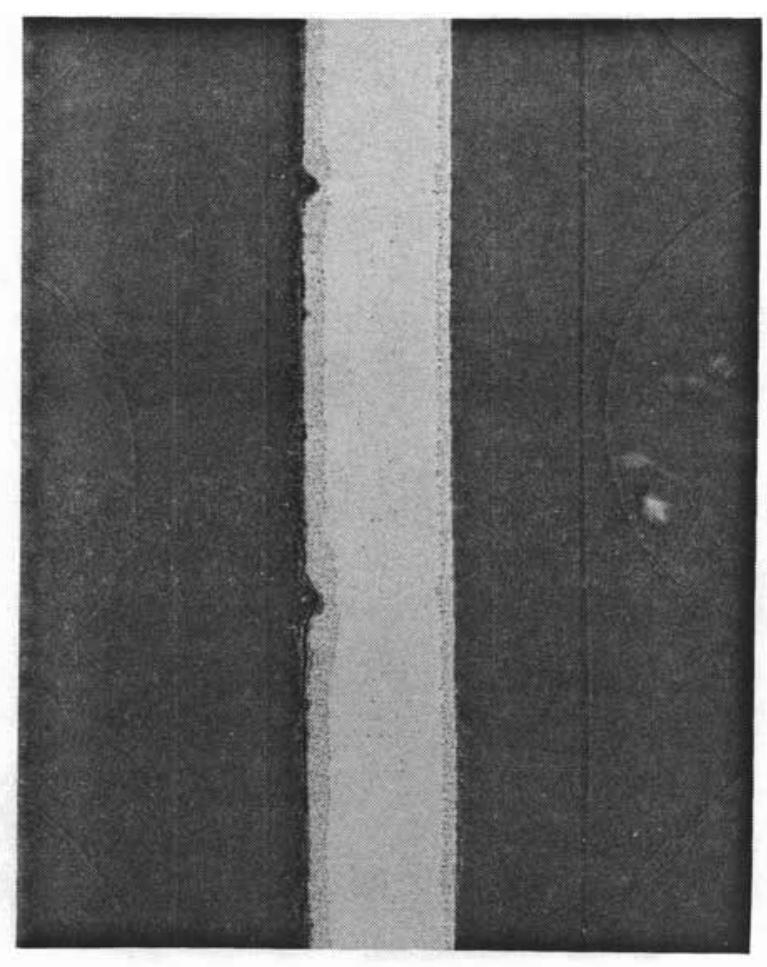

$10 X$
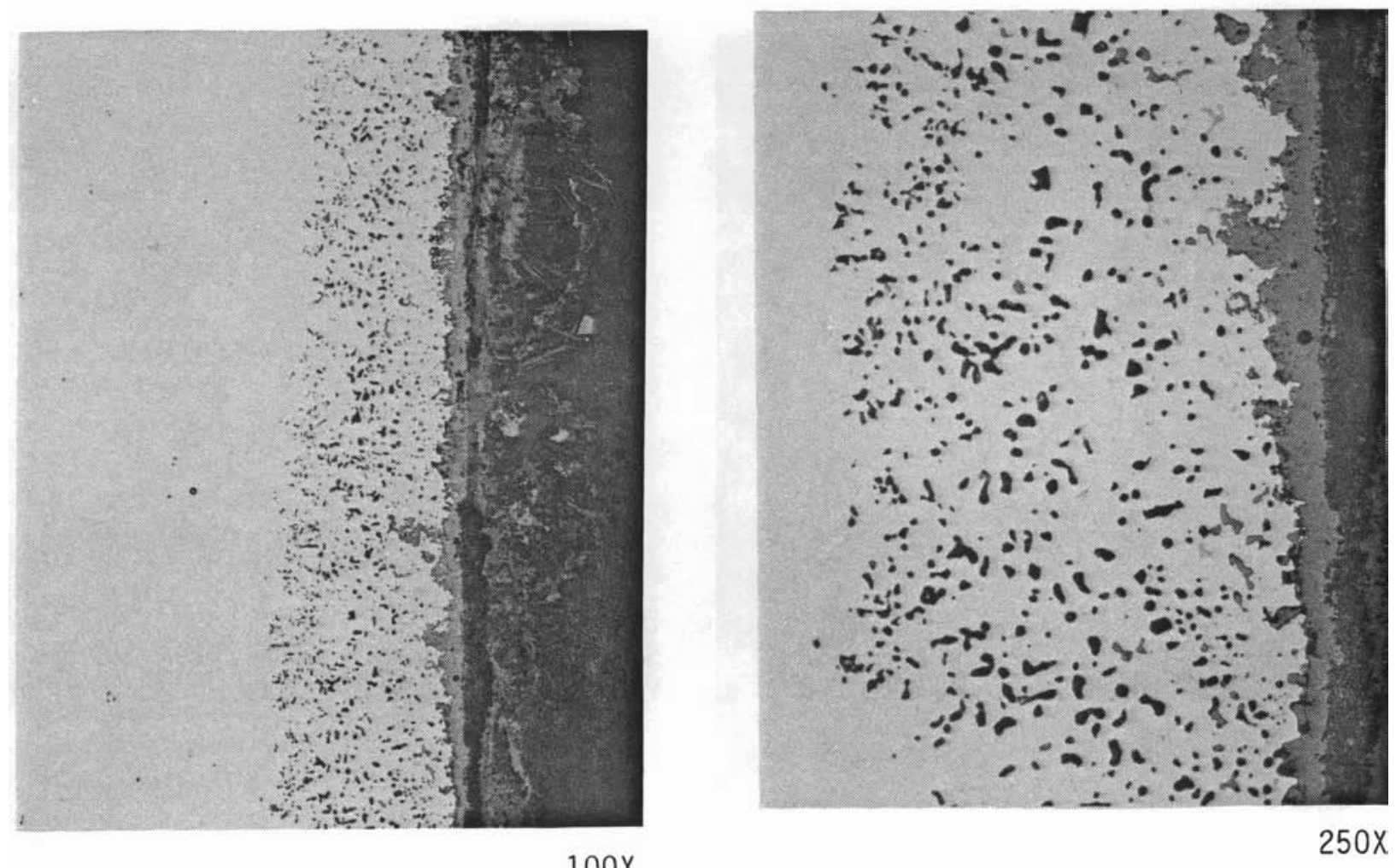

FIGURE A.96. Inconel-625 Sample Under 10X, 100X and 250X SEM Magnification 


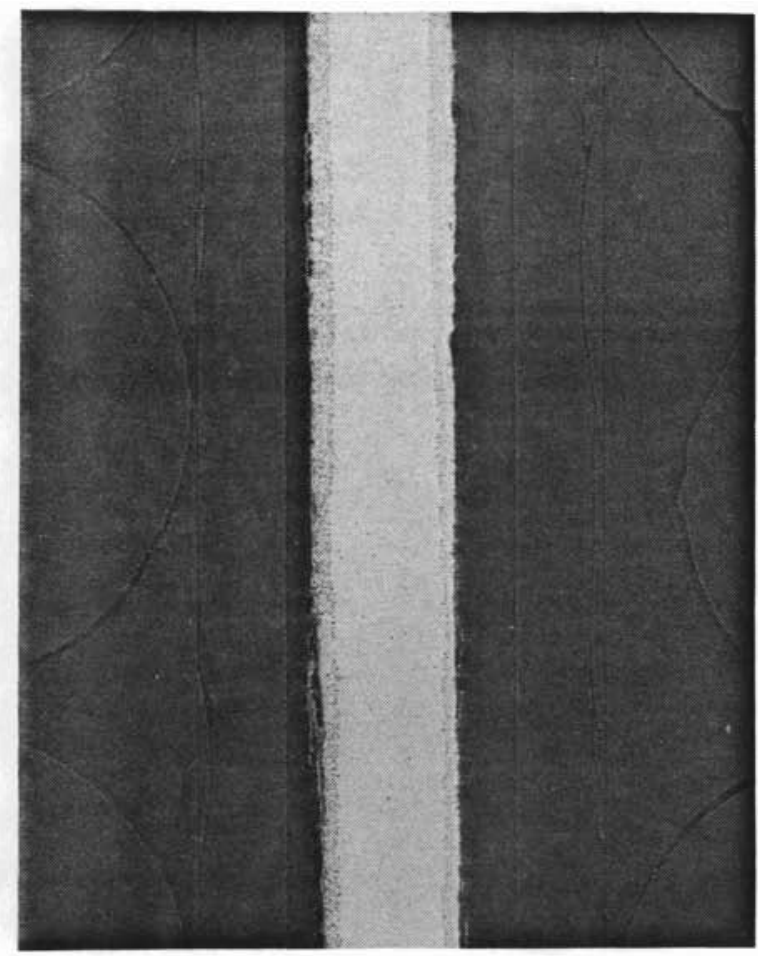

$10 x$
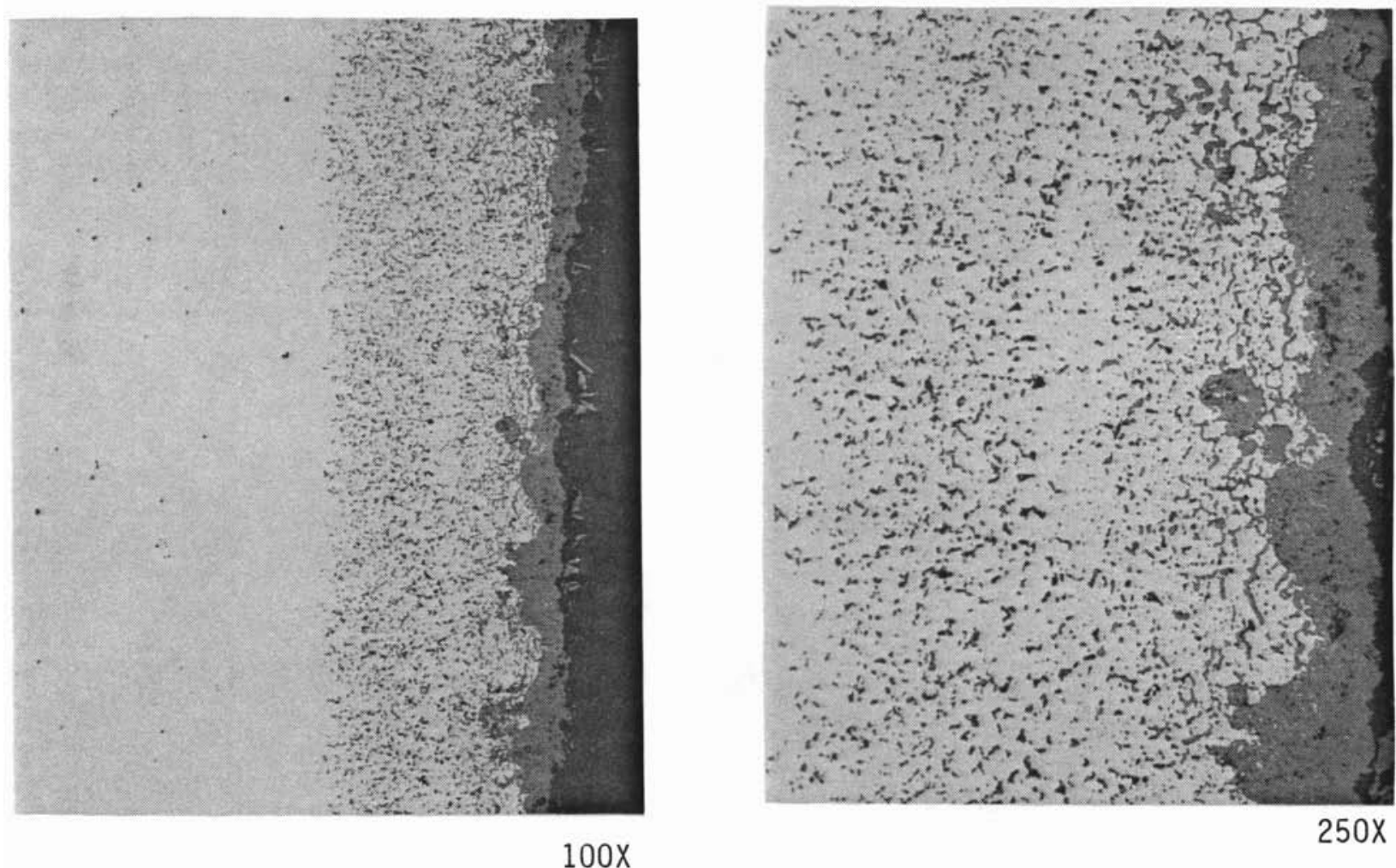

FIGURE A.97. Inconel-625 Sample Under 10X, 100X and 250X SEM Magnification 

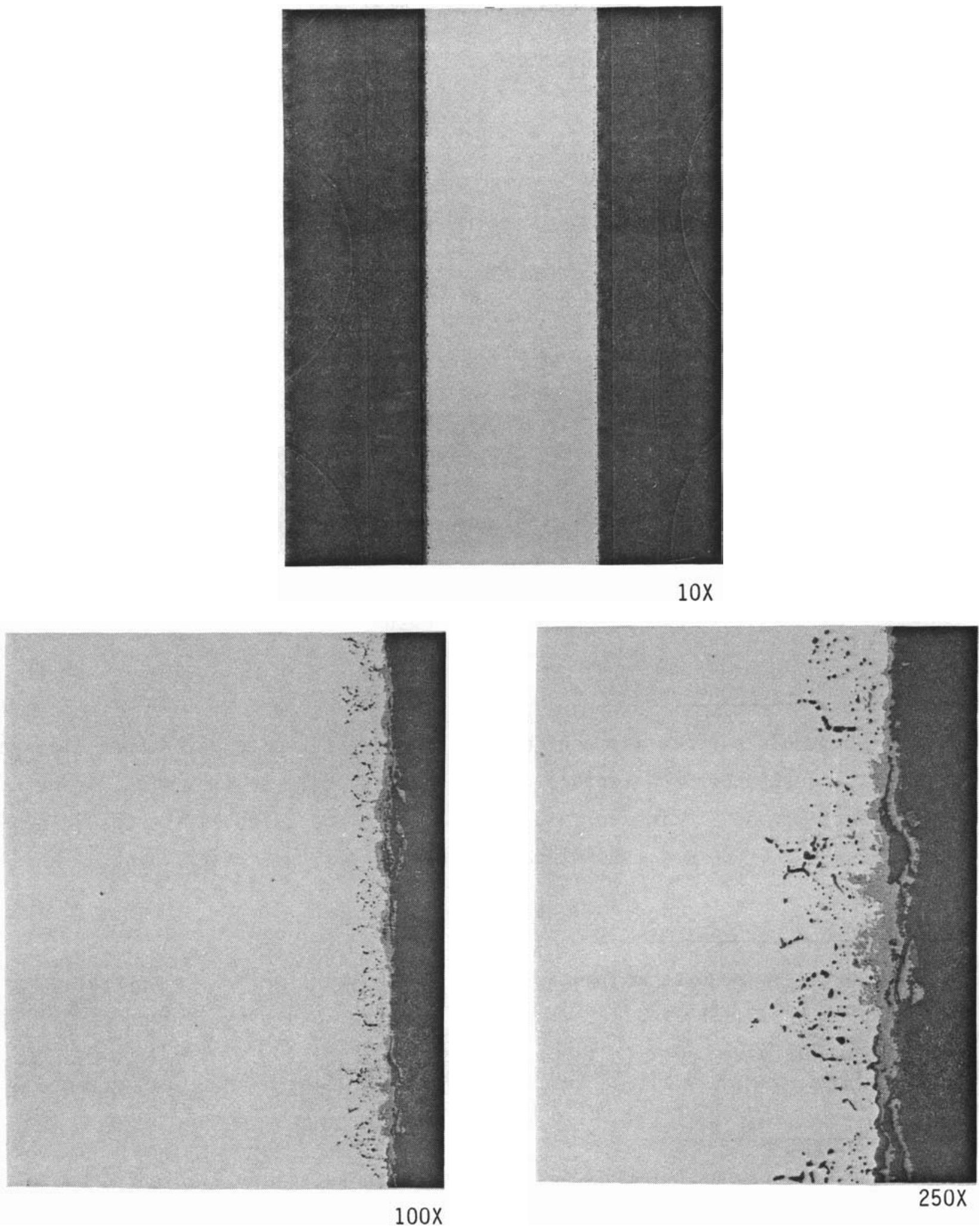

FIGURE A.98. Hastelloy Sample X Under 10X, 100X and 250X SEM Magnification 


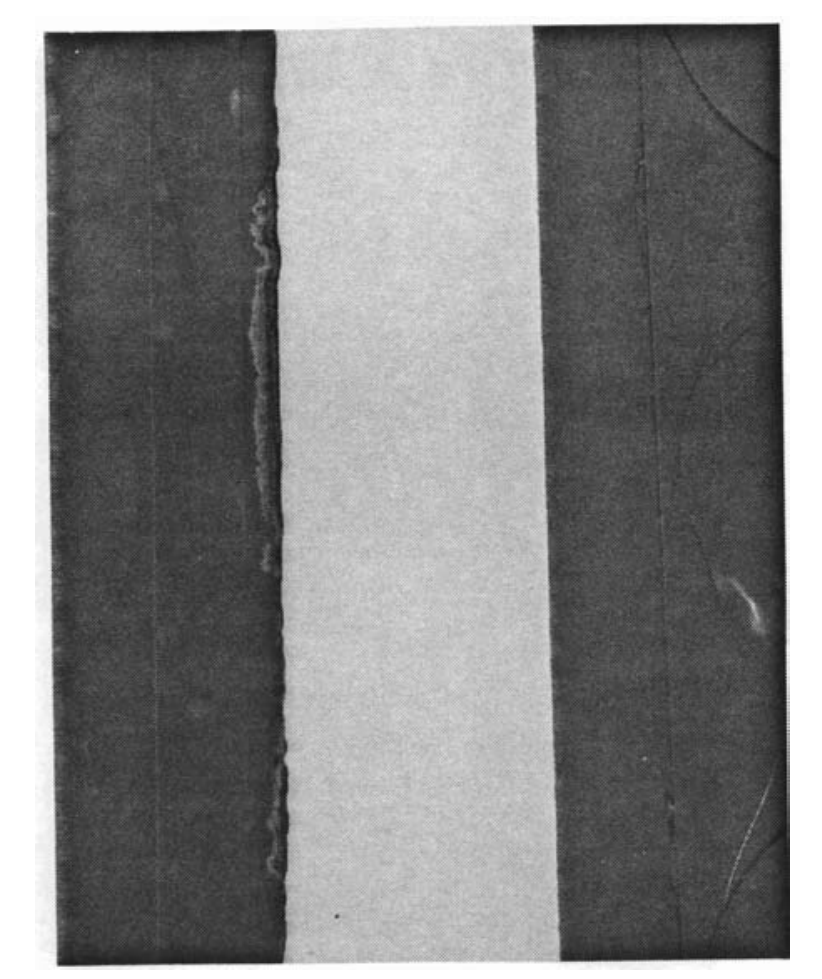

FIGURE A.99. Haynes 188 Sample \#1 Under 10X SEM Magnification

\section{Figure A.96 - Inconel-625\#2}

The sample surface was enriched in Fe and appears to have other glass components. Just under the surface was a Cr-enriched layer with significant amounts of $\mathrm{Ti}$ and $\mathrm{S}$. The solid grey area above the voids is the $\mathrm{Cr}_{2} \mathrm{O}_{3}$ layer and below the $\mathrm{Cr}_{2} \mathrm{O}_{3}$ was Inconel-625 depleted of $\mathrm{Cr}$, with many voids.

Figure A.97 - Inconel-625 \#1

The glass deposits on the surface of $\mathrm{Cr}_{2} \mathrm{O}_{3}$ had small NiCr crystals. Underneath the $\mathrm{Ni}-\mathrm{Cr}$ is a metal matrix of Inconel-625 with islands of $\mathrm{Cr}, \mathrm{S}$, and some $\mathrm{Ni}$.

\section{Figure A.98 - Hastelloy X}

The surface was enriched in $\mathrm{Fe}$ and with an adjacent layer enriched in $\mathrm{Cr}$. The substrate was the Hastelloy $X$ composition slightly depleted in $\mathrm{Cr}$. 

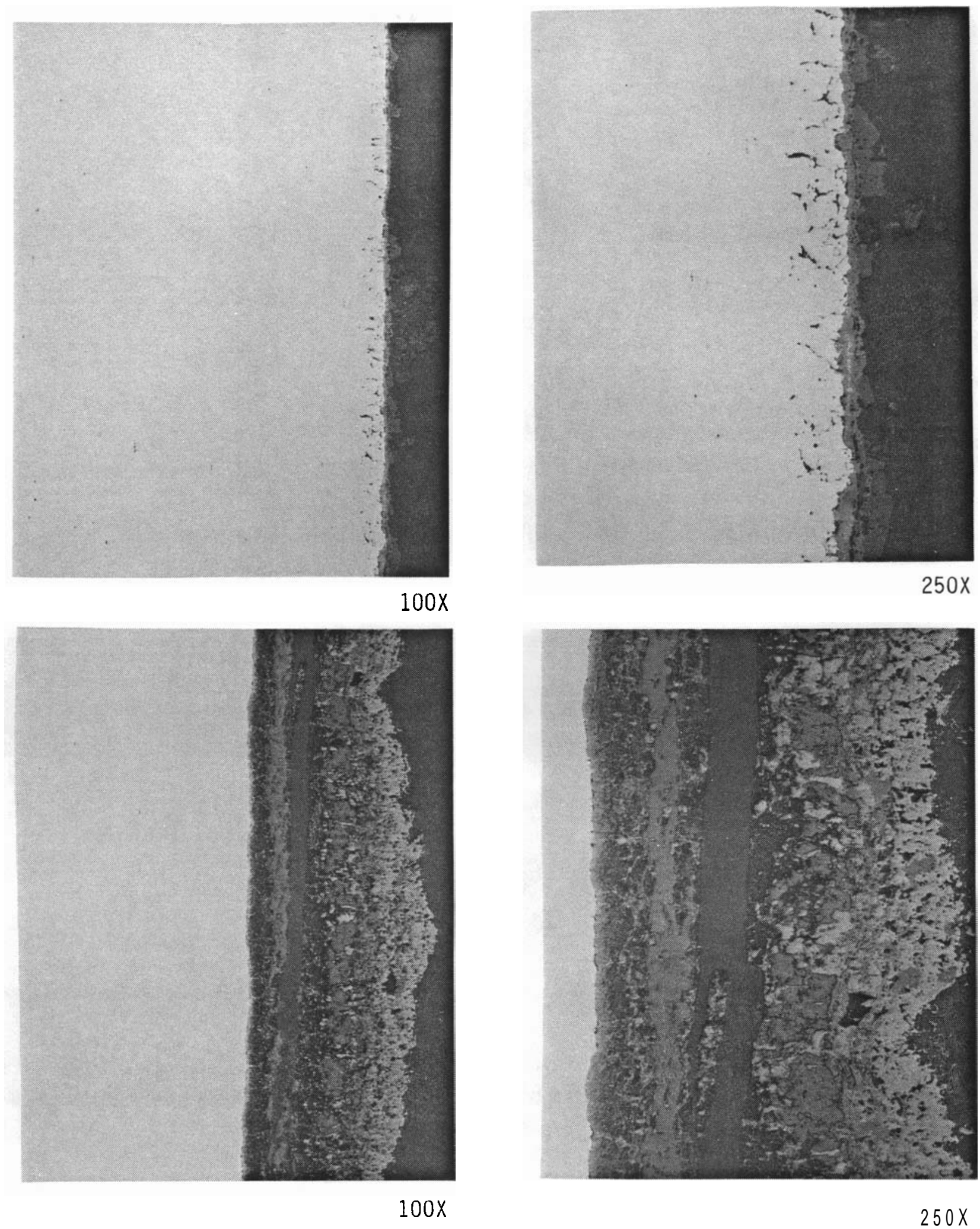

FIGURE A.100. Haynes 188 Sample \#1 Under 100X and 250X SEM Magnification 


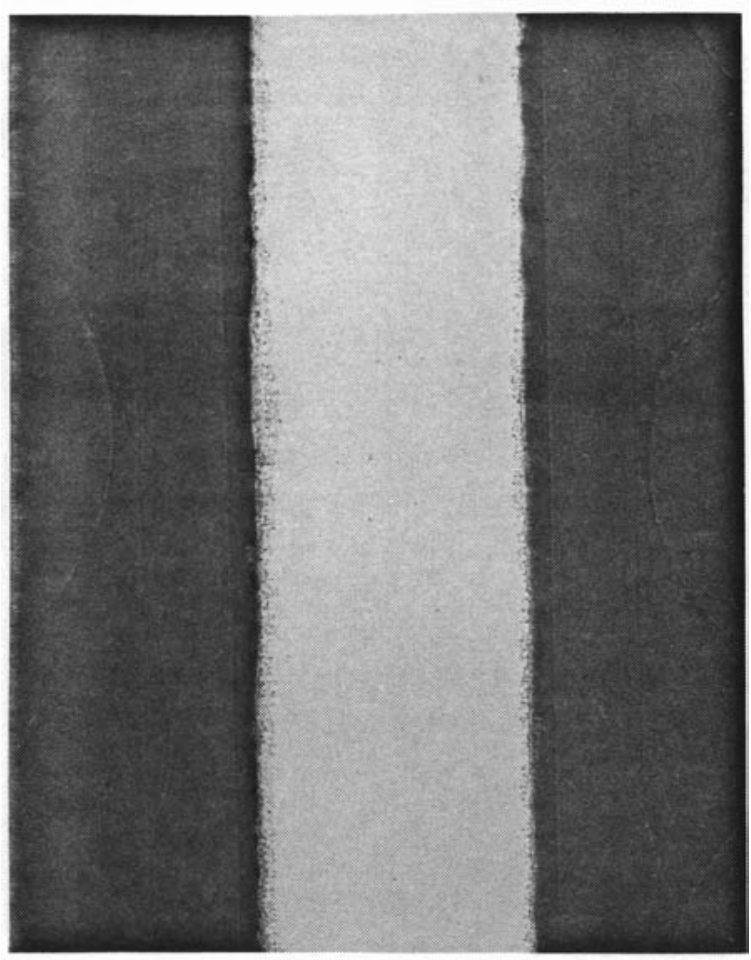

$10 x$
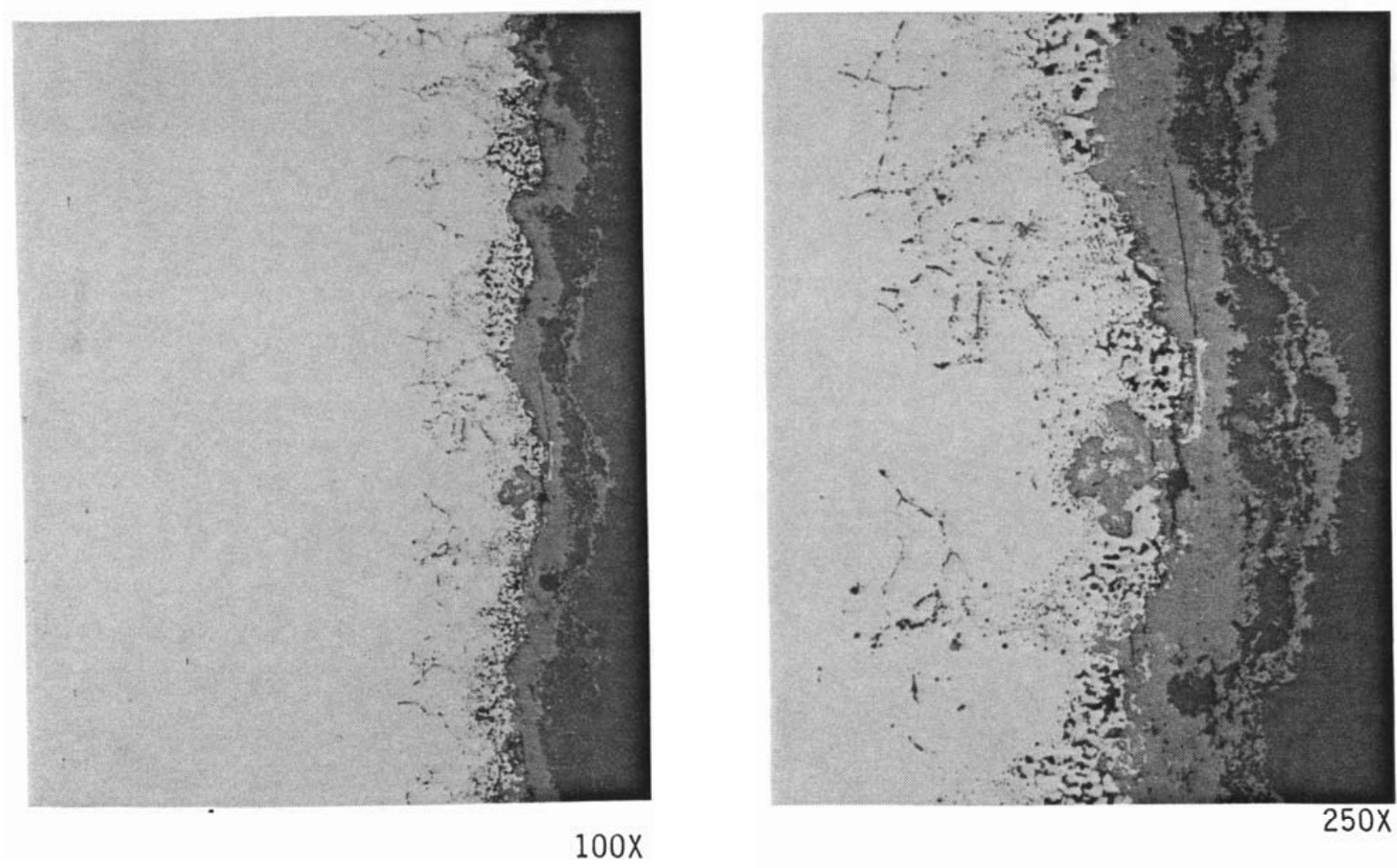

FIGURE A.I01. Haynes 188 Sample \#2 Under 10X, 100X and 250X SEM Magnification 

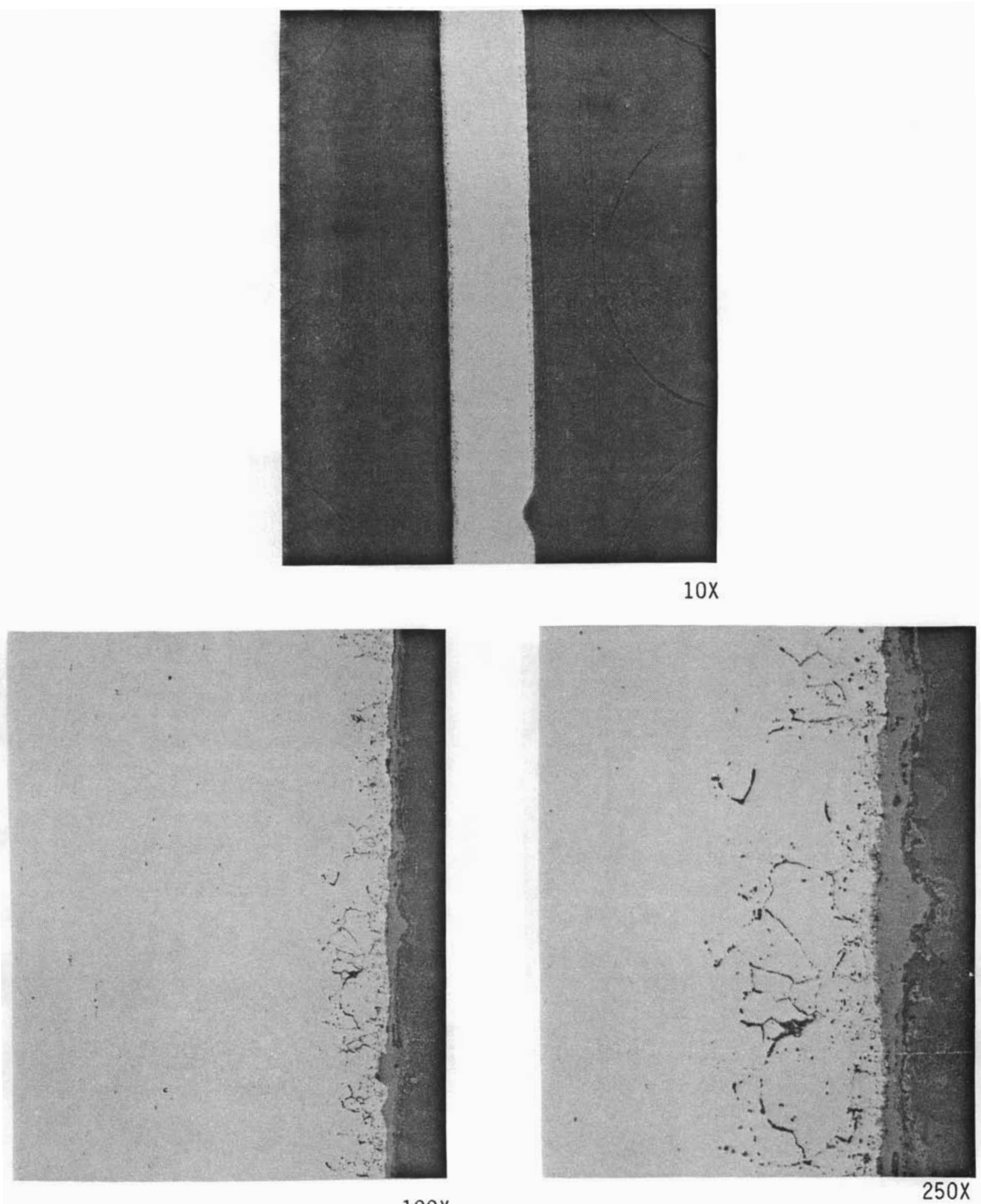

FIGURE A.102. Haynes 25 Sample Under 10X, 100X and 250X SEM Magnification 


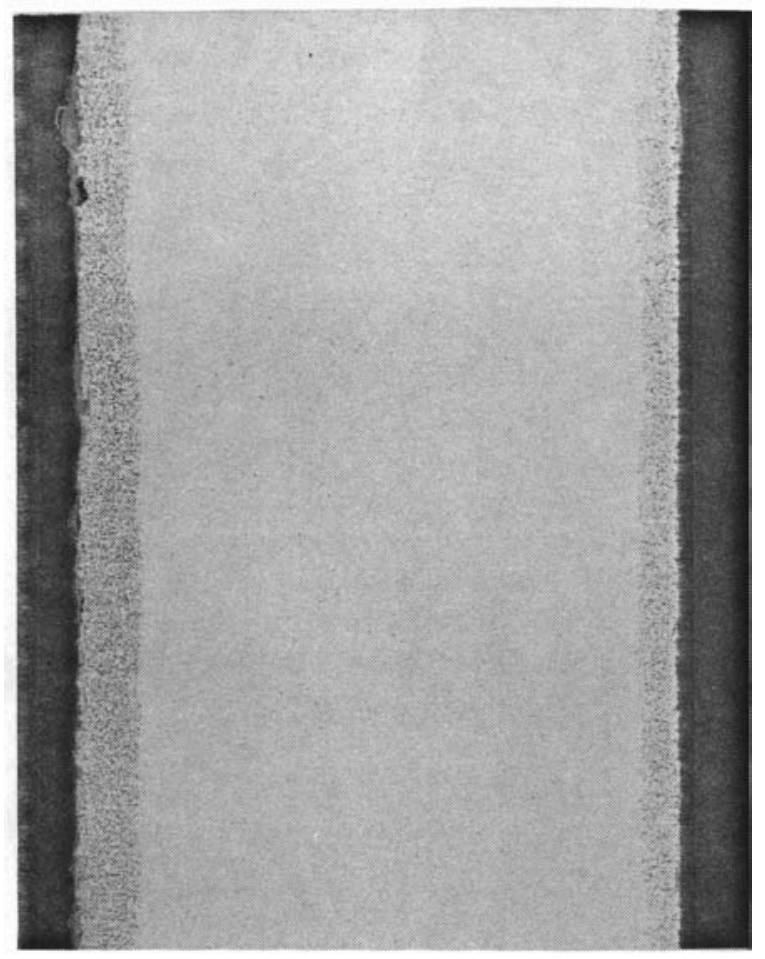

$10 x$
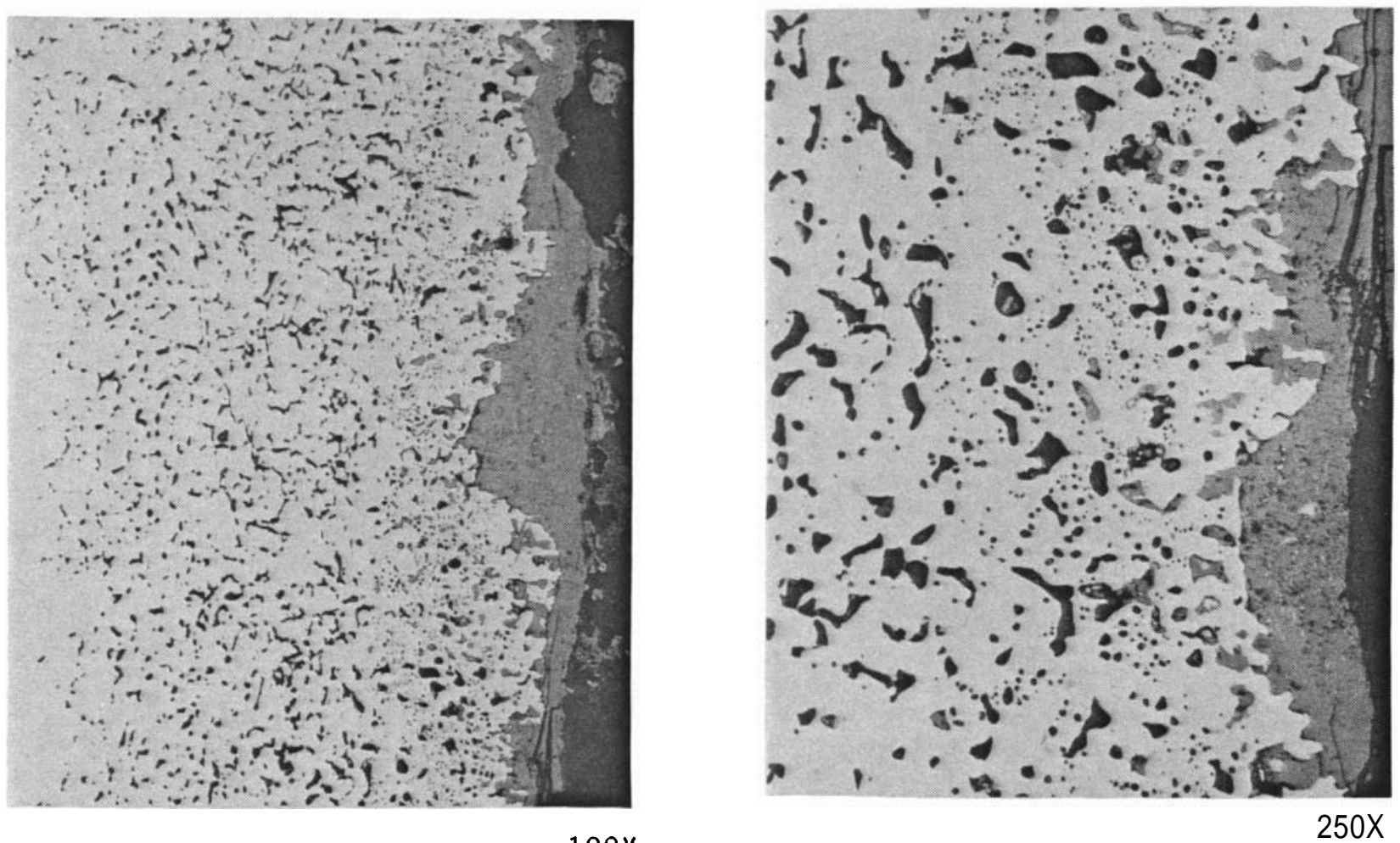

$100 x$

FIGURE A.103. Inconel-690 Sample Under 10X, 100X and 250X SEM Magnification 
TABLE A.91. Summary of Alloy Micrographs

\begin{tabular}{|c|c|c|c|}
\hline Alloy & $\begin{array}{l}\text { Exposure } \\
\text { Time, } \quad h\end{array}$ & $\begin{array}{c}\text { Void } \\
\text { Penetration, } \\
\text { um }\end{array}$ & $\begin{array}{c}\text { Thickness } \\
\text { Oxide Layer, } \\
\mu \mathrm{m}\end{array}$ \\
\hline Inconel-625 \#1 & 1850 & 300 & $40-50$ \\
\hline Inconel-615 \#2 & 2100 & 290 & 30 \\
\hline Hastelloy $X$ & 330 & 100 & $5-20$ \\
\hline Haynes 25 & 920 & 180 & $10-20$ \\
\hline Haynes $188 \# 1$ & 330 & 80 & 300 by $\mathrm{pit}$ \\
\hline Haynes 188 \#2 & 1850 & 260 & $40-80$ \\
\hline Inconel-690 & 2100 & 700 & $30-150$ \\
\hline
\end{tabular}

Figure A.99 \& A.100 - Haynes $188 \# 1$

The top two micrographs in Figure A.100 show a Cr-enriched layer on top of the metal substrate with voids. The bottom micrographs show a pitted area. The pitted area has a Cr-depleted surface, with significant amounts of $\mathrm{Si}$ and S. Other groups near the surface are enriched in $W$ or Mo, with very little $\mathrm{Cr}$. Below this mixture of groups is a $\mathrm{Cr}$ layer with less than half the original $\mathrm{Co}$ and $\mathrm{Ni}$. At the reaction interface there is a $\mathrm{Cr}$-enriched layer.

Figure A.101 - Haynes 188 \#2

The sample has a surface and substrate depleted in $\mathrm{O}$ with a $\mathrm{Cr}_{2} \mathrm{O}_{3}$ layer in the middle. The $\mathrm{Cr}_{2} \mathrm{O}_{3}$ layer contains almost $100 \% \mathrm{Cr}_{2} \mathrm{O}_{3}$. Some Te was found underneath the $\mathrm{Cr}_{2} \mathrm{O}_{3}$. The $\mathrm{W}$ was also depleted on the surface.

Figure A.102 - Haynes 25

The 10X micrograph shows a small pit developing. The general surface contains many cube-like crystals of $\mathrm{Cr}, \mathrm{Co}, \mathrm{Fe}, \mathrm{Ni}$, which are more enriched in $\mathrm{Cr}$ than the base alloy. The largest layer on top of the base metal is essentially all $\mathrm{Cr}_{2} \mathrm{O}_{3}$.

Figure A.103 - Inconel-690

The sample surface had $\mathrm{C}_{2} \mathrm{O}_{3}$ layer on top of a metal matrix of $\mathrm{Cr}$ depleted Inconel-690, voids, and islands of $\mathrm{Cr}$ and $\mathrm{S}$. 
$\underline{\text { PSCM }}$

The PSCM off-gas port was cleaned of deposits after nine months of operation, and severe pitting was observed. The off-gas port was Inconel-690 pipe, plasma spray coated with $80 \% \mathrm{Ni} / 20 \% \mathrm{Cr}$. This coating did not protect the pipe and appears to have spalled off. The Inconel viewports were also plasma spray coated, one with $\mathrm{Cr}_{2} \mathrm{O}_{3}$ and the other with $2 \mathrm{rO}-\mathrm{Y}_{2} \mathrm{O}_{3}$. Both the coatings appeared to have spalled, offering little protection to the metal viewports.

The Inconel-690 electrodes were removed from the melter and any adhering glass was chipped away so the electrodes could be inspected. Electrode surfaces normally below the glass surface showed no signs of corrosion. The portion of the electrodes exposed to the plenum vapors was spalling and contained some large pits. The corroded areas were magnetic with the pits being the most magnetic. The pits were found underneath large deposits of partially vitrified glass. These deposits are enriched in $\mathrm{Cl}$ and $\mathrm{S}$ in previous experiments, and the present deposits are similar. These types of deposits could be causing "hot corrosion," a thin-film salt corrosion process which is not well understood.

The plenum heater thimbles (Inconel-600, -601 and -690) showed the same pitting corrosion as the electrode, except that the Inconel-690 was not badly attacked. The Inconel-600 and -601 thimbles were attacked severely. One of the Inconel-600 thimbles was completely perforated after only 20 days of melter operation. The pits and surrounding areas were magnetic, indicating a loss of Cr from the alloy surface. The thimbles were also discolored where they were exposed to the plenum gases. The thimbles were fabricated from Inconel-600, Inconel-601 or Inconel-690; and only the two Inconel-690 thimbles remained unpitted. Of the five Inconel-600 thimbles used, four were pitted. The unpitted thimble was closest to the melter wall where the gas flow rate was lower. The Inconel-600 thimbles appear to be pitted the most. This can be seen in Figure A.104, where thimbles numbered 2, 3, 7 and 10 are of Inconel-600, and thimble number 8 is made of Inconel-601. Inconel-690 appears the most corrosion resistant of the three alloys used, but more testing is needed to determine resistance over the long term. 


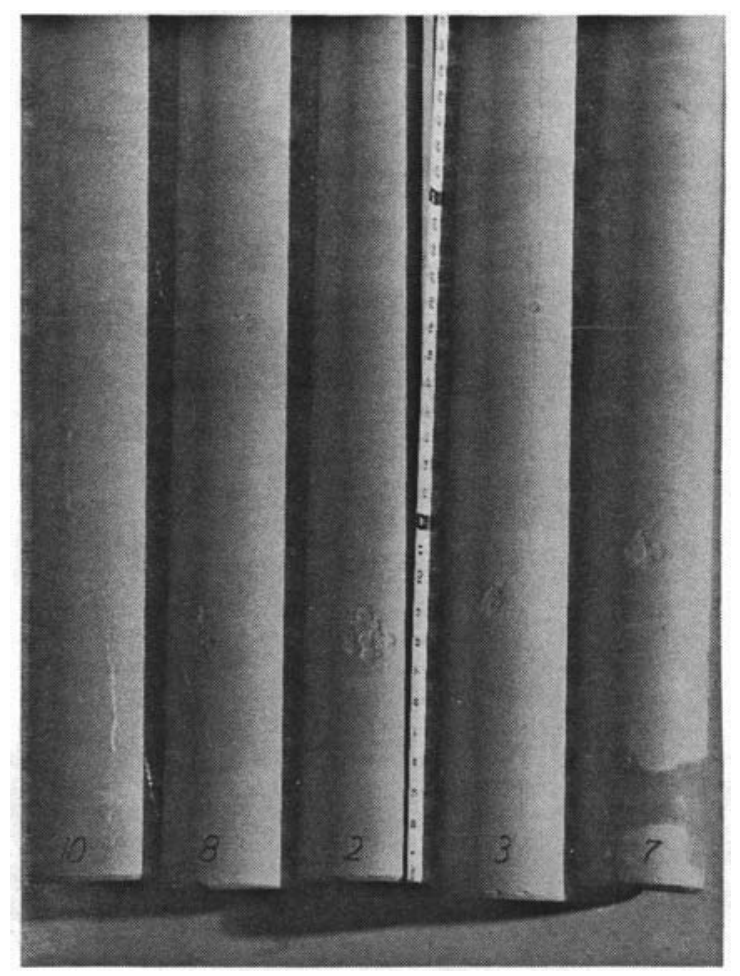

FIGURE A.104. PSCM Plenum Heater Thimbles

SEM micrographs of the plenum heater are shown in Figures A.105 through A.109. The micrographs show the $S$ under the $\mathrm{Cr}_{2} \mathrm{O}_{3}$ protective layer typical of sulfidation or hot corrosion.

The Incone1-690 plenum thermowell was also pitted excessively after PSCM-8. The original thermowell was $2.5 \mathrm{~cm}$ in diameter from top to bottom. Some areas had lost $0.25 \mathrm{am}$ as shown in Table A.92.

The feed nozzle used for the PSCM melter was closely inspected after PSCM-9, and many small pinholes were observed in the feed nozzle cooling jacket. The cooling jacket was then leak-tested with water at 40 psig, and many of the pinholes leaked. The overall leak rate was $<100 \mathrm{ml} / \mathrm{h}$. The outside of the cooling jacket, which is exposed to the melter plenum, was made of stainless steel with an Inconel-690 tip. The holes looked like typical $\mathrm{Cl}^{-}$ pitting corrosion in low pH solutions. This is reasonable since steam from the melter plenum condenses on the cold feed nozzle, and the condensate has a low $\mathrm{pH}$ and $\mathrm{a} \mathrm{Cl}^{-}$concentration of about $1000 \mathrm{ppm}$. 

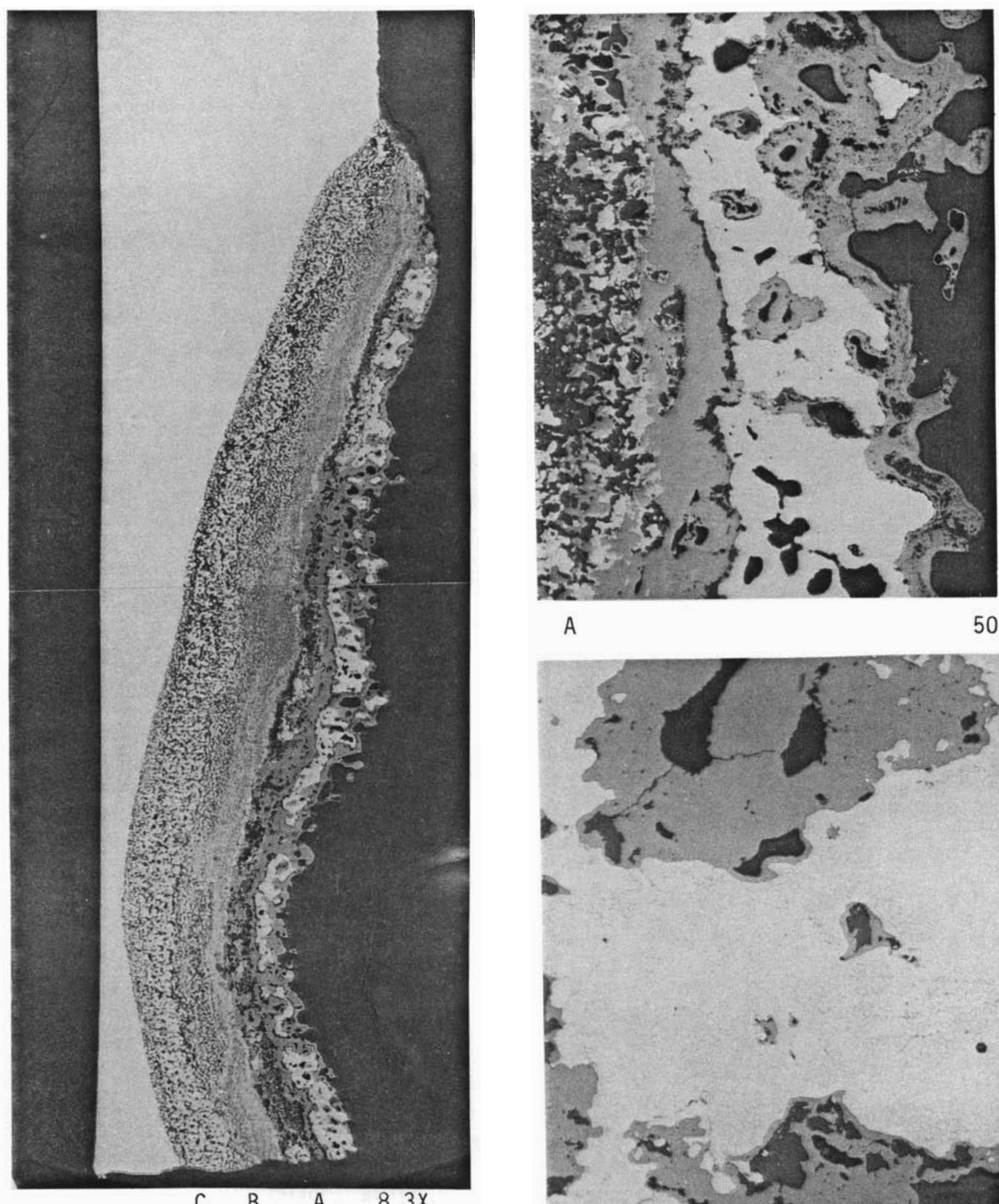

A

$50 \mathrm{x}$

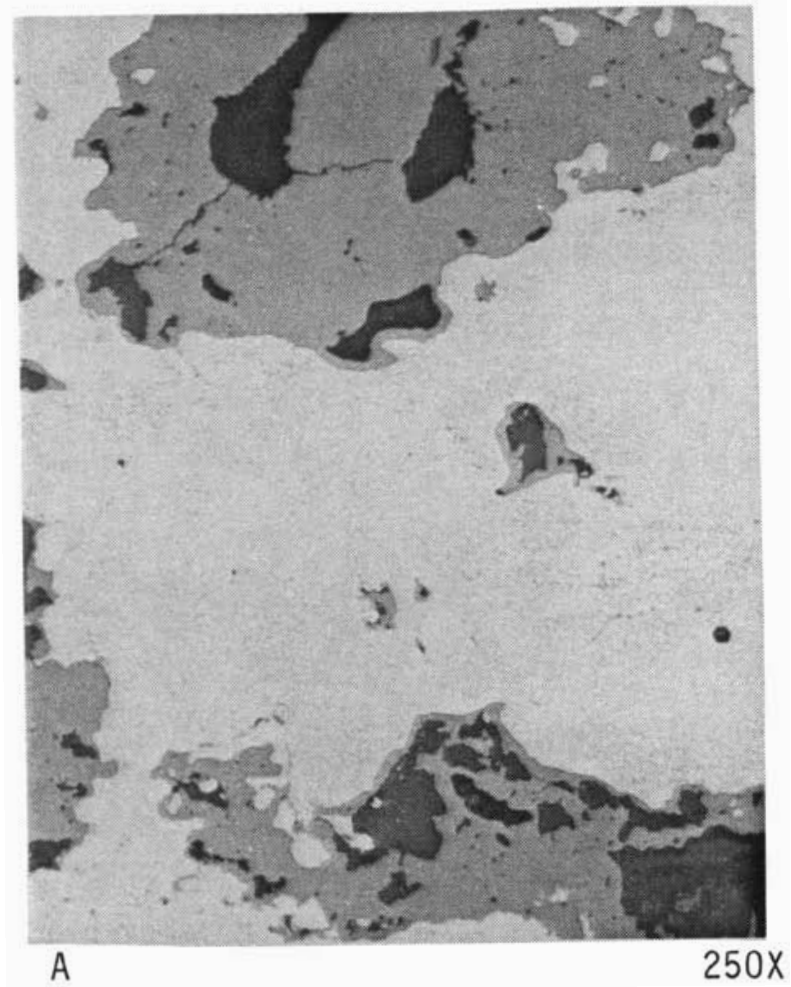

FIGURE A.105. Inconel-600 Thimble 8X SEM Cross Section with 50X and 250X Magnification 


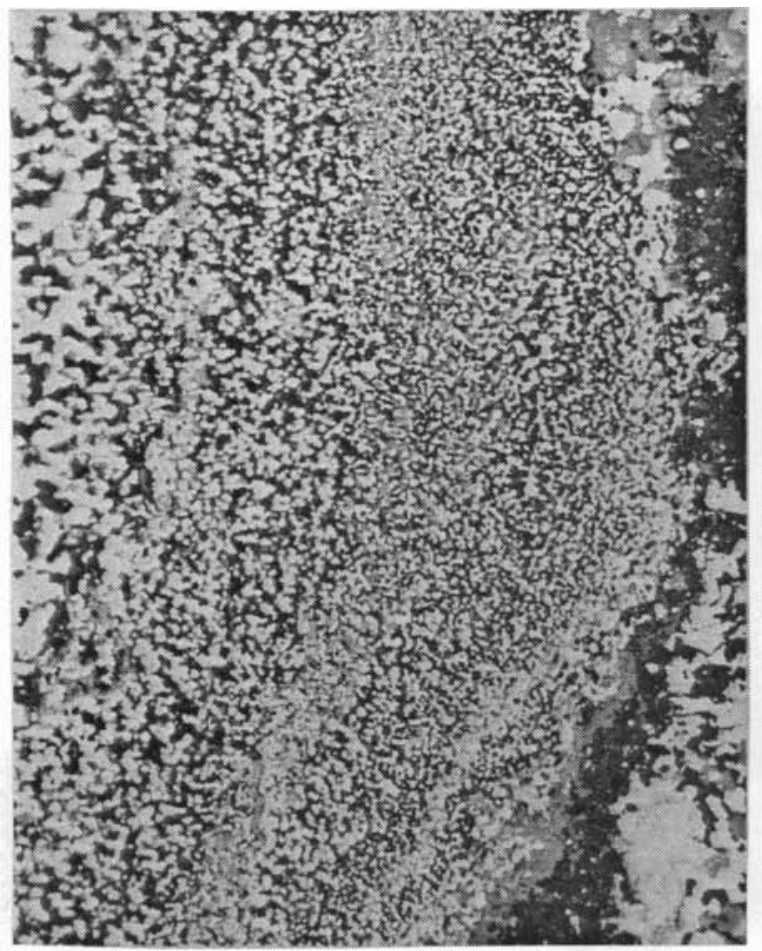

B

$50 x$
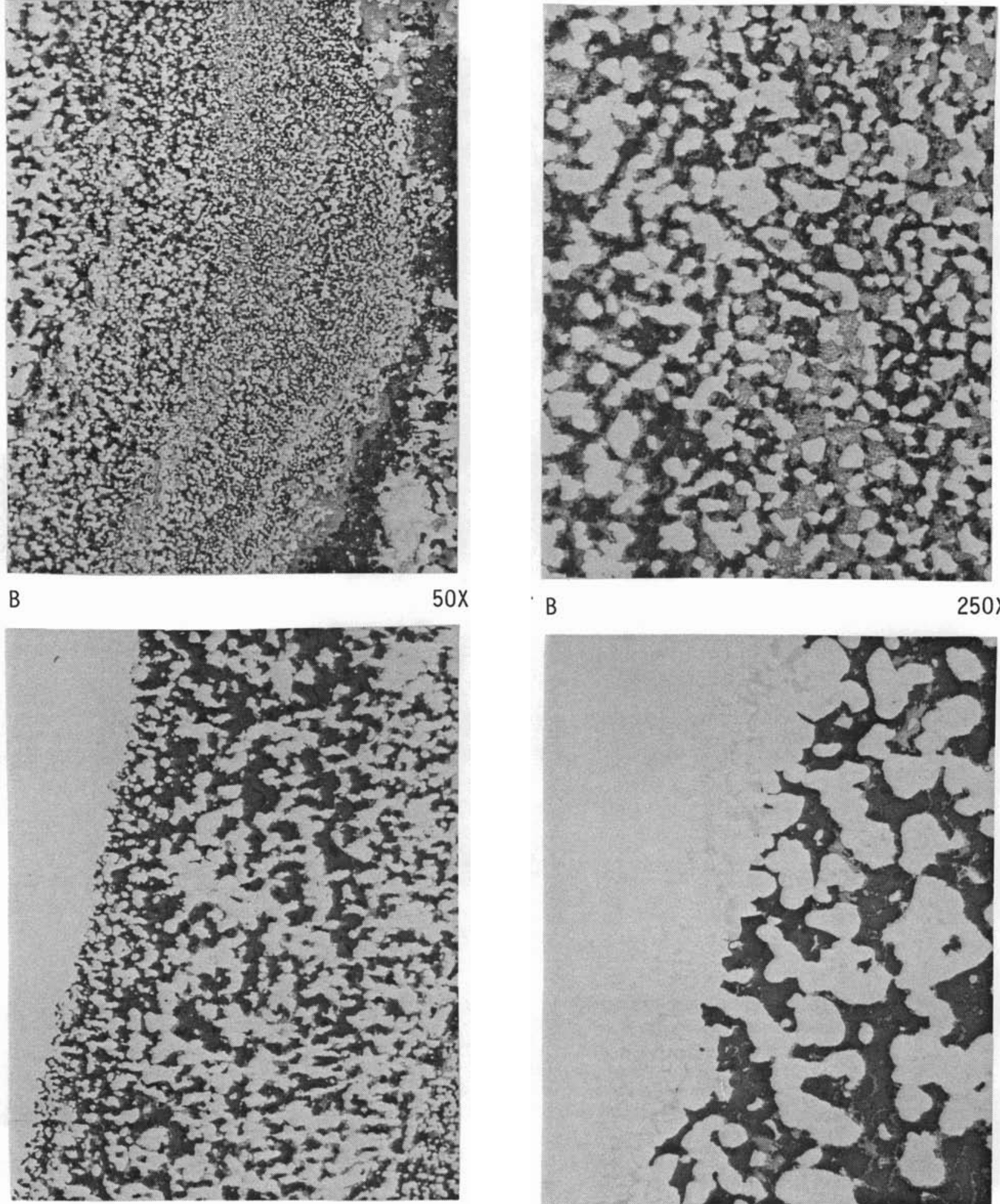

C

$50 x$

B

$250 x$

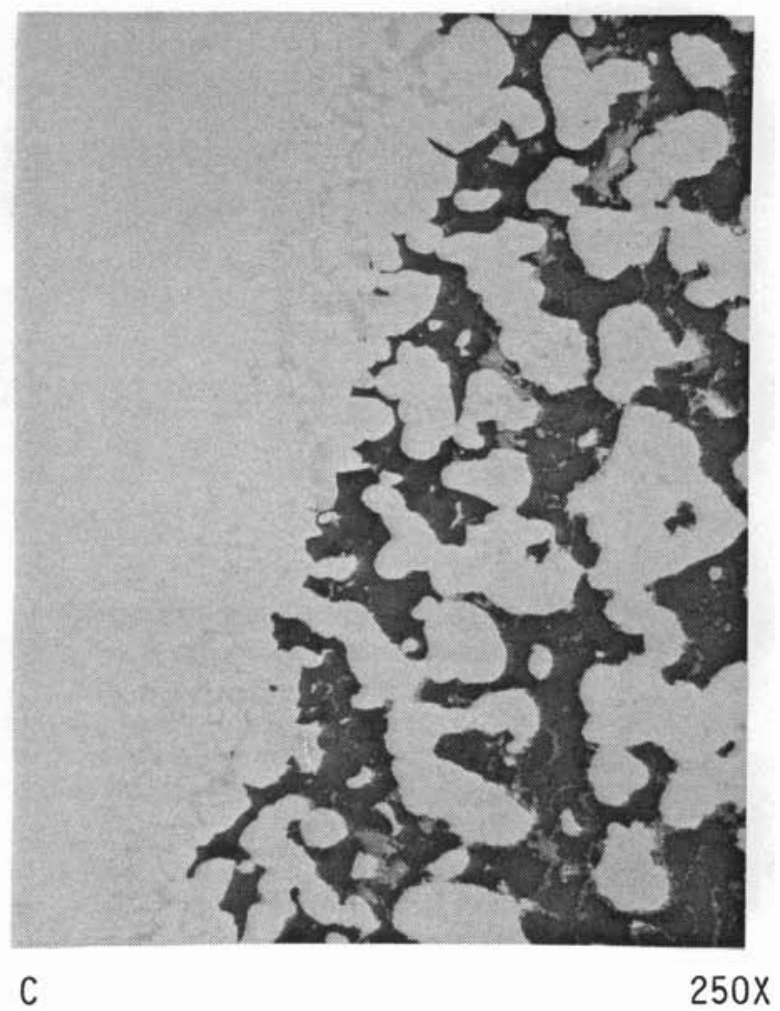

FIGURE A.106. Inconel-600 Thimble C.ross Sections of Regions B and C (see Figure 105) Under 50X and 250X Magnifications 


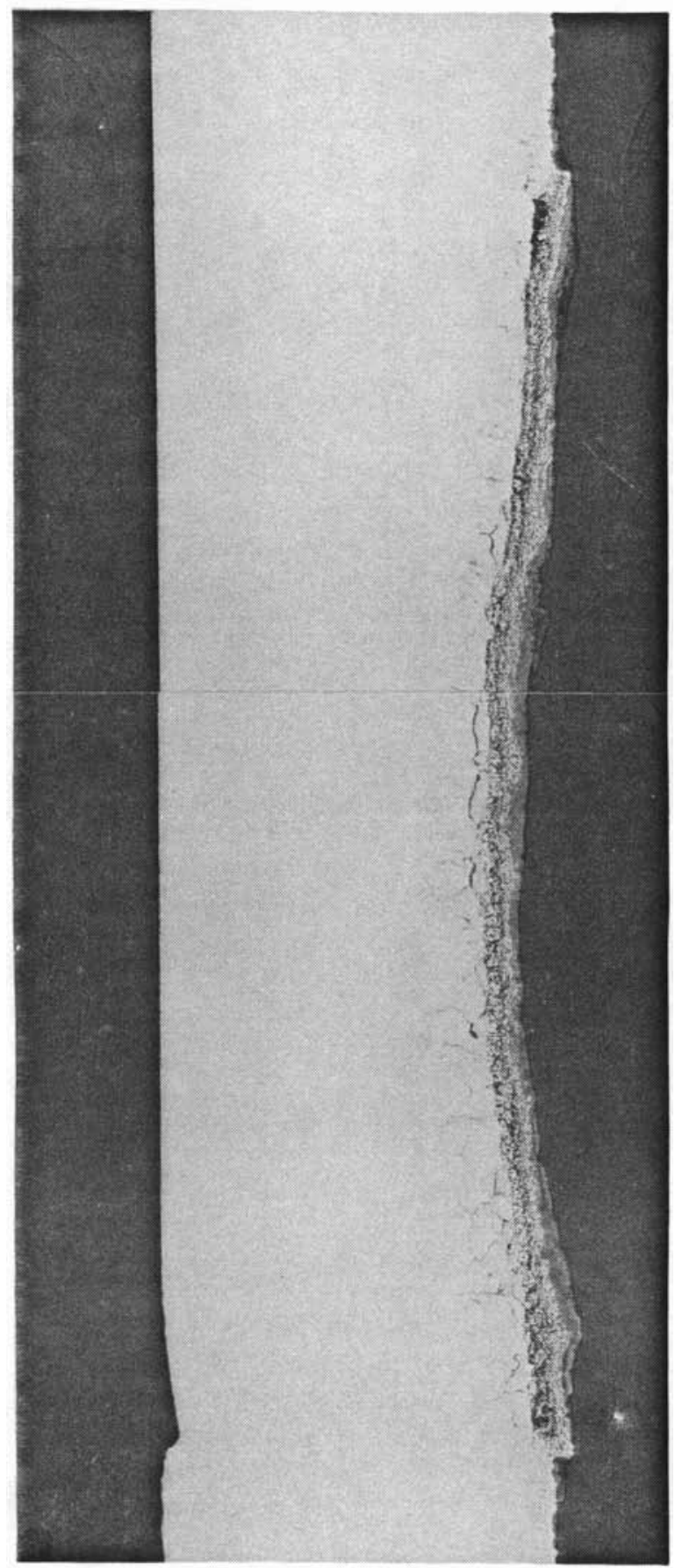

$$
8.3 x
$$

FIGURE A.107. Inconel-601 Thimble 8X, SEM Cross Section 


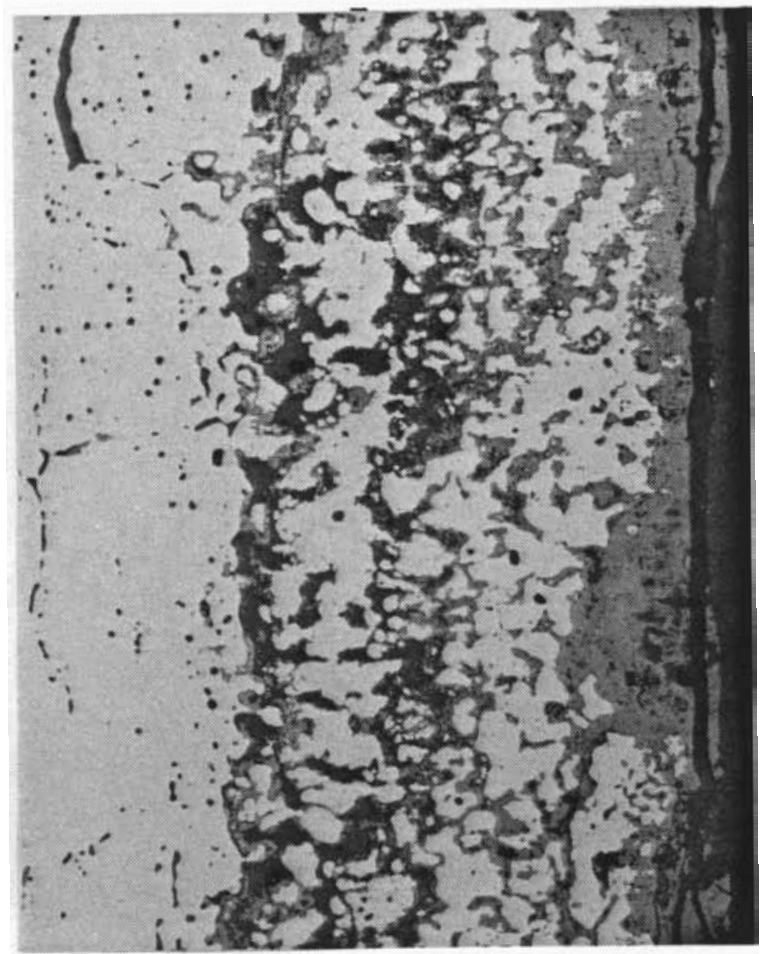

$100 x$

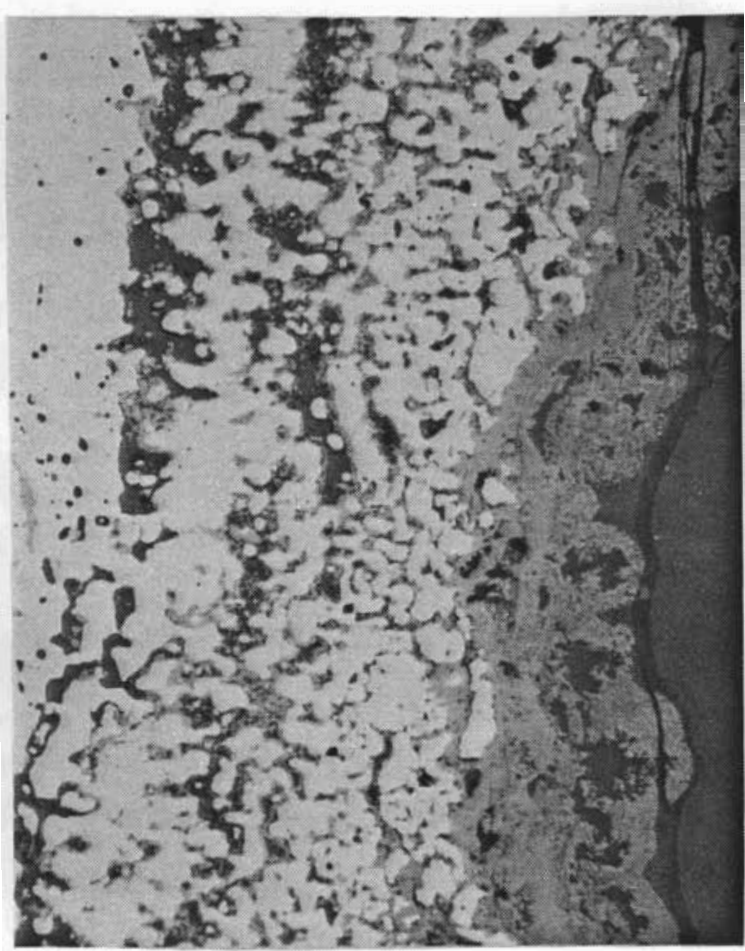

$100 x$
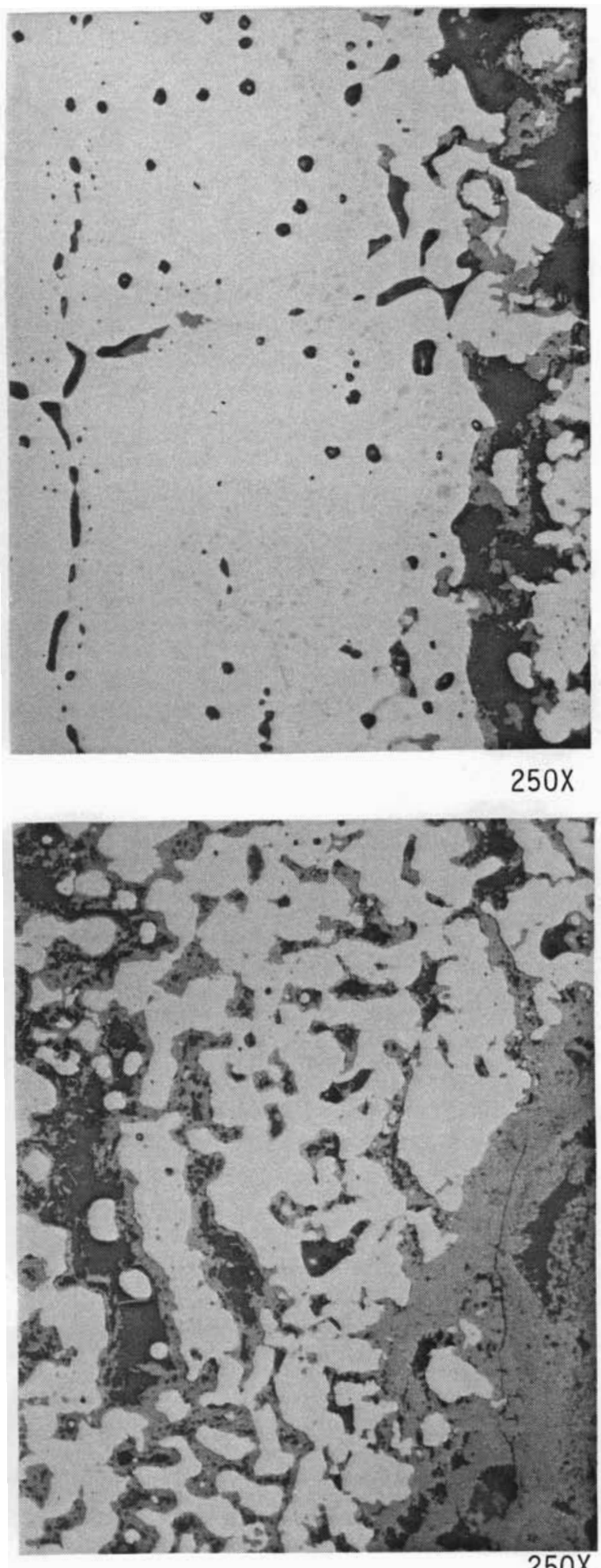

FIGURE A.108. Inconel-601 Cross Section Under 100X and 250X \$BM Magnification 

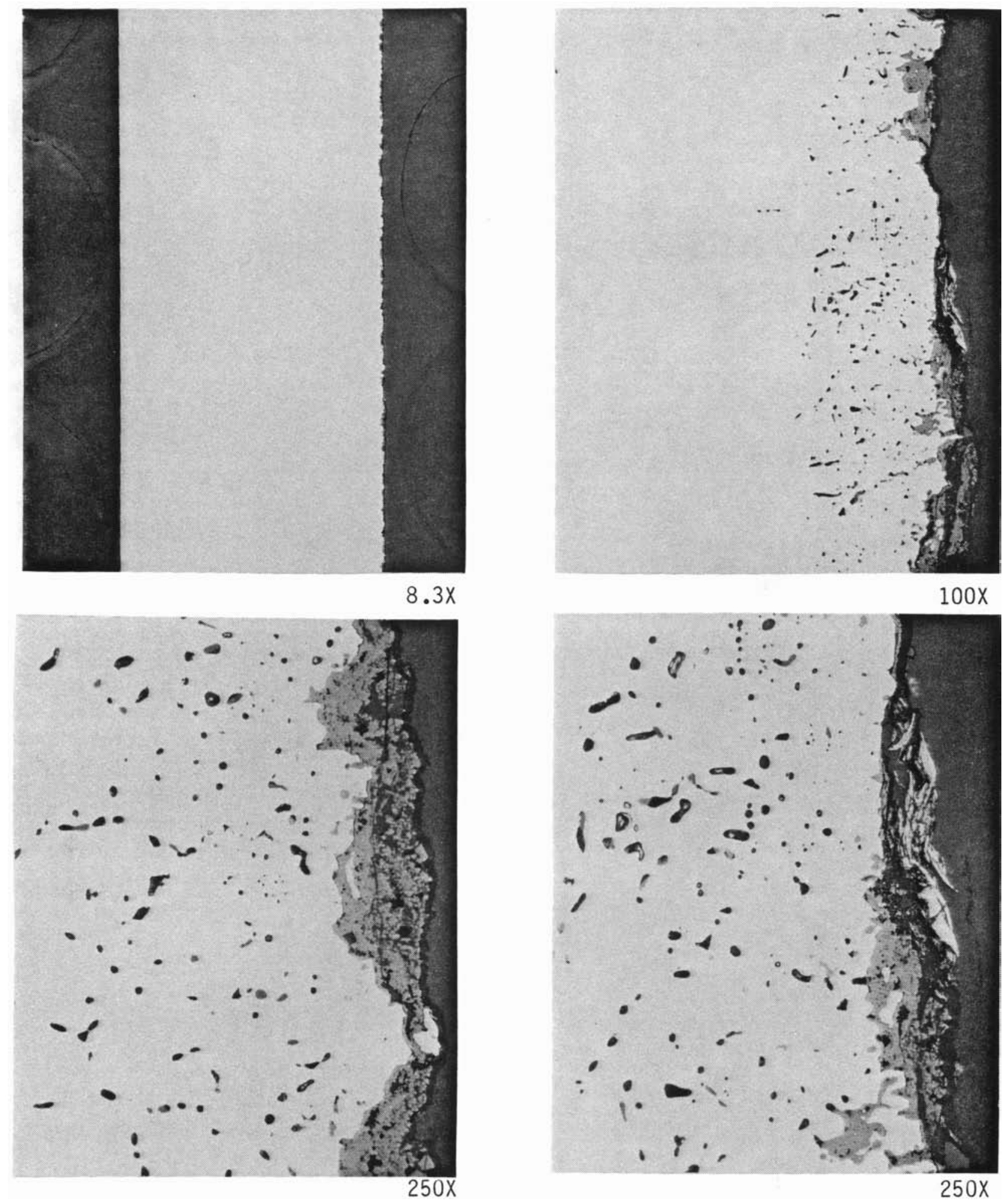

FIGURE A.109. Inconel-690 Thimble Cross Section Under 8.3X, 100X and 250X SEM Magnification 


\section{TABLE A.92. Plenum Thermowell Measurements}

\begin{tabular}{|c|c|}
\hline $\begin{array}{l}\text { Length From } \\
\text { Bottom of } \\
\text { Thermowel } 1, \mathrm{~cm}\end{array}$ & $\begin{array}{c}\text { Thermowell } \\
\text { Diameter, } \\
\mathrm{cm}\end{array}$ \\
\hline$u$ & 2.53 \\
\hline 7.6 & 2.47 \\
\hline 15 & 2.51 \\
\hline 23 & 2.45 \\
\hline 27 & $2.24(a)$ \\
\hline 30 & 2.31 \\
\hline 38 & 2.53 \\
\hline 46 & 2.52 \\
\hline 53 & 2.54 \\
\hline 61 & 2.54 \\
\hline 69 & 2.53 \\
\hline 76 & 2.51 \\
\hline
\end{tabular}

(a) Badly pitted.

The feed nozzle weld zones were the most severely attacked. The Inconel-690 tip was also pitted, but had no perforations, except where the Inconel was welded to the stainless steel. Inconel-690 is more resistant to pitting than stainless steel, but it also appears to have a limited service 1ife. A better material for this application would be Inconel-625, Hastelloy C-276 or titanium. However, the Hastelloy C-276 and the titanium would not last lony if cooliny water was lost to the feed nozzle. Prior plenum corrosion tests of Hastelloy C-4, which is similar to Hastelloy C-276 and titanium, have shown that they fail after a few days without cooling. Inconel-625 would be the best metallic material. Ceramic insulation would also work well if the thermal gradients did not cause it to crack.

\section{OFF-GAS SYSTEM}

Throughout the year, crevice and pitting corrosion has occurred in the melter's venturi scrubber system, which consists of a 316 SS venturi and 304L 
SS recirculation lines. The majority of the pits are in the heat-affected zones near welds. The corrosion is caused by the off-gas condensate, which contains $-1000 \mathrm{ppm} \mathrm{Cl}$ and has a $\mathrm{pH}$ of 3 .

The condensing vapors have also caused some stress corrosion cracking just prior to the venturi entrance. Recirculation lines are pitting because the recirculating solution is equivalent to the off-gas condensate under steadystate conditions. The corrosion process was probably assisted by $S$, $F e$ and $F$ ions. Corrosion studies indicate that 316 and $304 \mathrm{~L}$ SS are very susceptible to chloride attack in acidic solutions. Some consideration should be given to the material used in the initial off-gas quencher for a liquid-fed ceramic melter processing $\mathrm{SRL}$ defense waste. High $\mathrm{Ni}-\mathrm{Cr}-\mathrm{Mo}$ alloys are recommended (such as Hastelloy C-276 and Incone1-625) by material manufacturers for wet environments with high $\mathrm{Cl}$ concentrations. 


\section{OFF-GAS SYSTEM PERFORMANCE}

The off-gas system used for the PSCM is shown in Figure A.l10 with some performance characteristics and operating parameters. The system performance up to and including the first venturi scrubber will be discussed under two conditions: boosted and unboosted. The major difference between these modes of operation is the temperature of the off-gas exiting the rnelter.

Plenum-boosted experiments require a cooling spray nozzle at the off-gas exit to prevent fused deposits from forming in the off-gas line. The cooling spray also reduces corrosion rates of the metal off-gas piping. However, the presence of the cooling spray itself has been responsible for producing offgas-1ine blockages. During PSCM-8 an off-gas-line blockage formed as a result of an air-atomized water cooling spray. The nozzle's spray hit the side of the off-gas line, wetting it and causing particulate matter to collect and grow into a plug which eventually caused the off-gas-line blockage shown in Figure A.III.

The off-gas nozzle could be designed not to impinge on the pipe walls or collect water on the tip. During the PSCM-5 experiment, a spray nozzle that did not wet the off-gas pipes worked satisfactorily for the 5 days it was used. However, the spray cooled the plenum and thereby affected melter capacity. The air-atomized water cooling spray could also be replaced with an aironly or steam-cooling spray, but the mass requirements would be much higher.

Melter operation without plenum boosting does not require a cooling spray because the off-gas temperatures are under $400^{\circ} \mathrm{C}$ (compared to the 600 to $800^{\circ} \mathrm{C}$ temperatures when boosting is used). The $400^{\circ} \mathrm{C}$ temperature will not vitrify off-gas line deposits. Idling periods may cause high temperatures, but this can be minimized by keeping the air inleakage low.

Off-gas particulate does collect in the off-gas line, but the deposits are small and easily removed with high velocity air. The deposits are usually less than 118-in. thick in a 5-day run. Most of these deposits collect on protruding thermocouples and sampling nozzles. The elimination of all off-gas-line penetrations would significantly reduce material accumulation. The PSCM off gas line was 6 in. in diameter so the average gas velocity for a nonboosted 

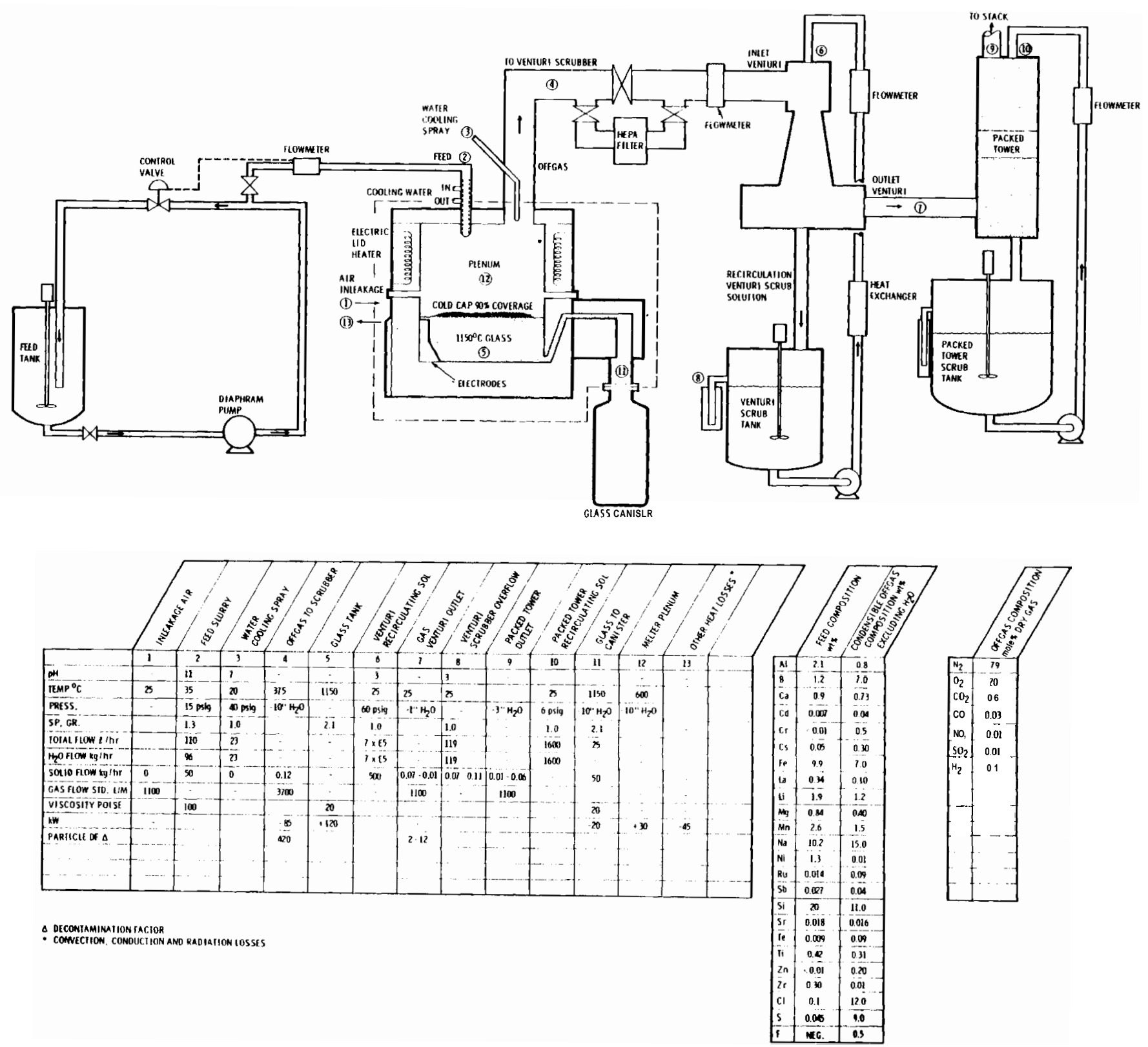

FIGURE A.IIO. Off-Gas System 


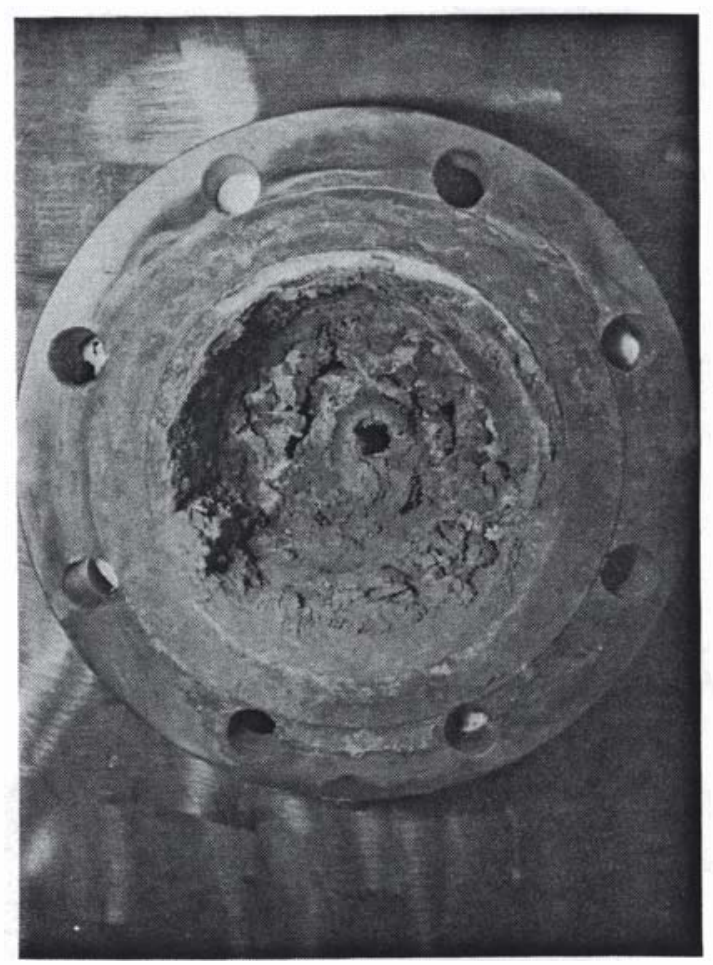

\section{FIGURE A.III. Material Buildup in Melter Plenum Exhaust Port}

experiment was $10 \mathrm{ft} / \mathrm{sec}$. This relatively slow gas velocity is not effective in sweeping out off-gas particulates. A smaller diameter pipe may be less likely to foul because of the higher gas flow rate. The material deposited in the off-gas line appear to be entrained feed enriched in Cs and other semivolatiles.

The close-coupled venturi scrubber associated with the PSCM was positioned about $5 \mathrm{ft}$ from the melter plenum to minimize the piping which is susceptible to particulate deposits and to allow a straight, unobstructed pipe section to the scrubber. The horizontally mounted venturi scrubber allowed water to collect in the off-gas-line throat of the venturi. A vertically mounted venturi with a separator box had been used previously with less wetting and particulate buildup at its entrance. Consequently, a vertical scrubber configuration appears to be preferred over horizonal mounting. Both venturis effectively condensed all the steam in the off gas, precluding the use of a downstream condenser except as a backup. 


\section{MATERIAL BALANCE Te., Se and Ru}

The PSCM melter was drained and cleaned, and a new I id was installed in December 1981. Since that time, five experiments have been performed: PSCM-4 throuyh PSCM-8. In each of these experiments, a significant percentage of Se, Te and Ru could not be accounted for by glass production and off-gas system losses. After PSCM-8, the melter was drained and inspected. The inspection revealed a large quantity of metal-like nodules in the position shown in Figure A.112. Each group was analyzed, and the results are shown in Table A.93. The total weight of the nodules collected was $6.16 \mathrm{~kg}$. The average nodule composition was mainly $\mathrm{Ni}$ and $\mathrm{S}$, with significant quantities of $\mathrm{Te}$, $\mathrm{Se}$ and Ru. Table A.94 is an attempt to account for all the Te, Se and Ru, which could not be accounted for during PSCM-4 through PSCM-8. The nodule samples were not homogeneous, which creates siynificant uncertainty in the calculated total of each element. The off-gas analysis for these elements is also subject to large errors because the concentrations are close to the analytical detection limits. With these limitations in mind, the missing Te and all but $10 \%$ of the Se can be accounted for. Much of the Ru is still unaccounted for due in part to the inaccuracy of nodules Ru analysis. Overall, the material balance gives general values on the fate of Te, Se and Ru in a ceramic melter with formic acid feed. The metal nodules accounted for $\sim 40 \%$ of the Te, $25 \%$ of the Se, and $20 \%$ of the Ru fed to the PSCM in formic acid feeds. 


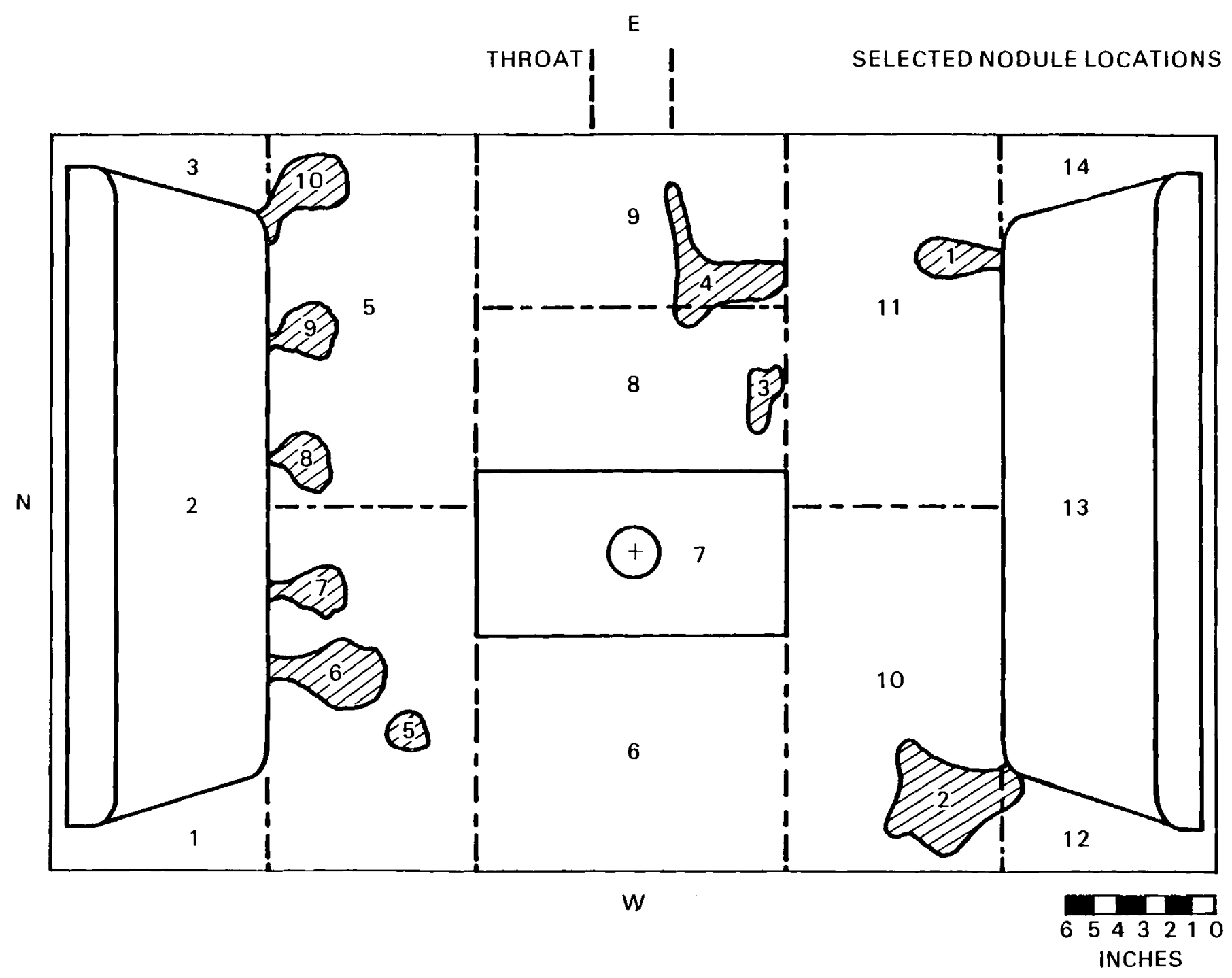

FIGURE A.112. PSCM-8 Melter Floor Survey 
TABLE A.93. Metal Found on Melter Floor

\begin{tabular}{|c|c|c|c|c|c|c|c|c|c|c|c|c|c|c|c|}
\hline \multirow[b]{2}{*}{ Element } & \multicolumn{10}{|c|}{ Locations Shown on Figure A.I } & \multirow{2}{*}{$\begin{array}{l}\text { Blue } \\
\text { Ball }\end{array}$} & \multirow{2}{*}{$\begin{array}{l}\text { Gold } \\
\text { Ball } \\
\end{array}$} & \multirow{2}{*}{$\begin{array}{c}\text { Fine } \\
\text { Speckled } \\
\text { Ball } \\
\end{array}$} & \multirow{2}{*}{$\begin{array}{c}\text { Shiny } \\
\text { Crystals } \\
\end{array}$} & \multirow{2}{*}{$\begin{array}{l}\text { Gold } \\
\text { Group }\end{array}$} \\
\hline & 15 & 25 & 35 & 45 & $5 S$ & $6 S$ & $7 \mathrm{~S}$ & $8 \mathrm{~S}$ & $9 \mathrm{~S}$ & 105 & & & & & \\
\hline B & $<0.04$ & $<0.04$ & $<0.04$ & $<0.04$ & $<0.04$ & $<0.04$ & $<0.04$ & $<0.04$ & $<0.04$ & $<0.04$ & $<0.04$ & $<0.04$ & $<0.04$ & $<0.04$ & $: 0.04$ \\
\hline $\mathrm{Ca}$ & $<0.15$ & $<0.15$ & $<0.15$ & $<0.15$ & $<0.15$ & $<0.15$ & $<0.15$ & $<0.15$ & $<0.15$ & $<0.15$ & $<0.15$ & $<0.15$ & $<0.15$ & $<0.15$ & $<0.15$ \\
\hline $\mathrm{Cd}$ & $<0.01$ & $<0.01$ & $<0.01$ & $<0.01$ & $<0.01$ & $<0.01$ & $<0.01$ & $<0.01$ & $<0.01$ & $<0.01$ & $: 0.01$ & $<0.01$ & $<0.01$ & $<0.01$ & $<0.01$ \\
\hline Cs & $<0.04$ & $<0.04$ & $<0.04$ & $<0.04$ & $<0.04$ & $<0.04$ & $<0.04$ & $<0.04$ & $<0.04$ & $<0.04$ & $<0.04$ & $<0.04$ & $: 0.04$ & $<0.04$ & $<0.04$ \\
\hline $\mathrm{Cu}$ & 2.1 & 2.9 & 2.6 & 2.2 & 1.9 & 2.0 & 1.8 & 1.9 & 1.9 & 1.9 & 1.6 & 1.5 & 1.5 & 2.9 & 2.0 \\
\hline $\mathrm{Fe}$ & $<0.10$ & $<0.10$ & $<0.10$ & $<0.10$ & $<0.10$ & $<0.10$ & $<0.10$ & $<0.10$ & $<0.10$ & $<0.10$ & $<0.10$ & $<0.10$ & $<0.10$ & $<0.10$ & $<0.10$ \\
\hline$L i$ & $<0.02$ & $<0.02$ & $<0.02$ & $<0.02$ & $<0.02$ & $<0.02$ & $<0.02$ & $<0.02$ & $<0.02$ & $<0.02$ & $<0.02$ & 0.02 & $(0.02$ & $<0.02$ & (0.02 \\
\hline $\mathrm{Mg}$ & $<0.04$ & $<0.04$ & $<0.04$ & $<0.04$ & $<0.04$ & $<0.04$ & $<0.04$ & $<0.04$ & $<0.04$ & $<0.04$ & $<0.04$ & 0.04 & $<0.04$ & $<0.04$ & $(0.04$ \\
\hline $\mathrm{Mn}$ & $<0.02$ & $<0.02$ & $<0.02$ & $<0.02$ & $<0.02$ & $<0.02$ & $<0.02$ & $<0.02$ & $<0.02$ & $<0.02$ & $<0.02$ & $<0.02$ & $<0.02$ & $<0.02$ & $(0.02$ \\
\hline $\mathrm{Na}$ & $<0.5$ & $<0.5$ & $<0.5$ & $<0.5$ & $<0.5$ & $<0.5$ & $<0.5$ & $<0.5$ & $<0.5$ & $<0.5$ & $<0.5$ & $: 0.5$ & $(0.5$ & $<0.5$ & $<0.5$ \\
\hline $\mathrm{Ni}$ & 56 & 57 & 37 & 53 & 56 & 59 & 58 & 43 & 50 & 57 & 62 & 63 & 51 & 35 & 50 \\
\hline $\mathrm{Ru}$ & 1.6 & 1.4 & 9.1 & 2.3 & 3.0 & 1.7 & 1.7 & 5.7 & 4.4 & 2.2 & 0.24 & 0.77 & 7.8 & 29.0 & 1.1 \\
\hline $\mathrm{s}$ & 18 & 21 & 10 & 17 & 17 & 18 & 19 & 13 & 14 & 15 & 20 & 23 & 12 & 8 & 15 \\
\hline $\mathrm{Sb}$ & 0.21 & 0.34 & 0.06 & 0.16 & 0.20 & 0.26 & 0.21 & 0.12 & 0.19 & 0.25 & 0.25 & 0.33 & 0.16 & $B D$ & \\
\hline $\mathrm{Se}$ & 2.8 & 2.3 & 5.7 & 3.0 & 2.5 & 2.1 & 2.5 & 5.1 & 4.0 & 2.3 & 1.5 & 1.5 & 3.6 & 3.3 & 3.2 \\
\hline $\mathrm{Sr}$ & $<0.003$ & $<0.003$ & $<0.003$ & $<0.003$ & $<0.003$ & $<0.003$ & $<0.003$ & $<0.003$ & $<0.003$ & $<0.003$ & $(0.003$ & $<0.003$ & 0.003 & $<0.003$ & $<0.003$ \\
\hline $\mathrm{Te}$ & 11 & 9.7 & 21 & 11 & 9.8 & 8.8 & 9.9 & 18 & 14 & 9.3 & 7 & 6.9 & 12 & 10 & 7.1 \\
\hline
\end{tabular}


TABLE A.94. Te, Se and Ru Material Between PSCM-4 and PSCM-8

\begin{tabular}{|c|c|c|c|c|c|c|}
\hline \multirow[b]{2}{*}{ Element } & \multirow[b]{2}{*}{$\begin{array}{l}\text { Run No. } \\
\text { PSCM }\end{array}$} & \multicolumn{5}{|c|}{ Weight in grams } \\
\hline & & Feed & Glass & Off-Gas & $\begin{array}{l}\text { Melter Floor } \\
\text { Nodules } \\
\end{array}$ & $\begin{array}{l}\text { Unaccounted } \\
\text { For } \\
\end{array}$ \\
\hline $\mathrm{Te}$ & $\begin{array}{c}4 \\
5 \\
6 \\
7 \\
8 \\
\text { Total }\end{array}$ & $\begin{array}{r}163 \\
200 \\
314 \\
468 \\
763 \\
1908\end{array}$ & $\begin{array}{r}80 \\
100 \\
100 \\
140 \\
150 \\
570\end{array}$ & $\begin{array}{r}50 \\
60 \\
100 \\
30 \\
250 \\
490\end{array}$ & $600-900$ & $\sim 0$ \\
\hline Se & $\begin{array}{c}4 \\
5 \\
6 \\
7 \\
8 \\
\text { Total }\end{array}$ & $\begin{array}{r}430 \\
390 \\
100 \\
80 \\
150 \\
1150\end{array}$ & $\begin{array}{r}<140 \\
<170 \\
<50 \\
<30 \\
<80 \\
<470\end{array}$ & $\begin{array}{r}70 \\
70 \\
20 \\
30 \\
30 \\
220\end{array}$ & 300 & 150 \\
\hline Ru & $\begin{array}{c}4 \\
5 \\
6 \\
7 \\
8 \\
\text { Total }\end{array}$ & $\begin{array}{r}2240 \\
400 \\
450 \\
330 \\
0 \\
3420\end{array}$ & $\begin{array}{r}1220 \\
220 \\
220 \\
180 \\
0 \\
1840\end{array}$ & $\sim 0$ & $200-1200$ & $600-1600$ \\
\hline
\end{tabular}





\section{DISTRIBUTION}

No. of

Copies

\section{OFFSITE}

27 DOE Technical Information Center

R. D. Smith

Division of Waste Management

Nuclear Regulatory Commission

Washington, DC 20555

W. E. Mott

DOE Division of Environmental Control Technology

Washinyton, DC 20545

4 DOE Terminal Waste Disposal and

GTN Remedial Action

Washington, DC 20545

ATTN: J. E. Baublitz, NE-24

F. E. Coffman, NE-20

J. R. Coleman, NE-23

D. J. McGoff, NE-23

3 DOE Office of Defense Waste and

Byproducts Management

GTN

Washington, DC 20545

ATTN: J. E. Dieckhoner

J. J. Jicha

G. K. Oertel

W. W. Ballard, Jr.

DOE Office of Spent Fuel Management and Reprocessing Systems

NE-40, GTN

Washington, DC 20545

S. A. Mann

DOE Chicago Operations Office

9800 South Cass Avenue

Argonne, IL 60439

J. 0. Neff

DOE National Waste Program Office

505 King Avenue

Columbus, OH 43201
No. of

Copies
J. D. Hamric

DOE Idaho Operations Office

550 2nd Street

Idaho Falls, ID 83401

2 DOE Savannah River Operations Office

P. 0. Box A

Aiken, SC 29801

ATTN: E. S. Goldberg

T. B. Hindman

3 Exxon Nuclear Idaho

P. 0. Box 2800

Idaho Falls, ID 83401

ATTN: D. L. Concotta

J. D. Christian

File Copy

3 Battelle Memorial Institute

Office of Nuclear Waste Isolation

505 King Avenue

Columbus, OH 43201

ATTN: N. E. Carter

S. Goldsmith

B. Rawles

6 E. I - du Pont de Nemours Co. Savannah River Laboratory Aiken, SC 29808

ATTN: J. L. Crandall

E. J. Hennelly

H. L. Hull

S. Mirshak

D. Witt

T. Wright

R. Williams

Electric Power Research

Institute

$3412 \mathrm{Hillview}$ Avenue

Palo Alto, CA 94304 
No. of

Copies

R. Williams

Electric Power Research Institute $3412 \mathrm{Hi} l$ lview Avenue

Palo Alto, CA 94304

J. L. Knabenschuh

Nuclear Fuels Services, Inc.

P. 0. Box 191

West Valley, NY 14171

2 Bechtel National, Inc.

P. 0. Box 3965

San Francisco, CA 94119

ATTN: J. L. Jardine

W. A Freeby

\section{ONSITE}

5 DOE Richland Operations Office

H. E. Ransom

0 . J. Elgert

R. D. I zatt

J. J. Schreiber (2)

5 Rockwell Hanford Operations

R. N. Gurley

J. W. Patterson

J. H. Roecker

D. D. Wodrich

File Copy

Westinyhouse Hanford Company

A. G. Blasewitz
No. of

Copies

41 Pacific Northwest Laboratory

W. J. Bjorklund

W. F. Bonner

L. A. Bray

R. A Brouns

T. D. Chikalla

R. D. Dierks

L. J. Ethridge

R. W. Goles (10)

M. S. Hanson

F. T. Hara

J. H. Jarrett

D. E. Knowlton

L. T. Lakey

D. E. Larson

J. M. Latkovich

R. C. Liikala

R. P. Marshall/W. R. Wiley/

D. B. Cearlock

J. L. MCElroy

J. E Mende1/M. D. Merz

J. E. Minor

R. E Nightingale

J. M. Perez, Jr.

A M. Platt

G. J. Sevigny

H. H. Van Tuyl

Technical Information (5)

Publishing Coordination (2) 